Elvira Gabriela Ciacco da Silva Dias

\title{
AVALIAÇÃO DE IMPACTO AMBIENTAL DE PROJETOS DE MINERAÇÃO NO ESTADO DE SÃO PAULO:
}

A ETAPA DE ACOMPANHAMENTO

Tese apresentada à Escola Politécnica da Universidade de São Paulo para obtenção do título de Doutor em Engenharia.

Área de Concentração:

Engenharia Mineral

Orientador:

Luis Enrique Sánchez

São Paulo

2001 


\section{Dias, Elvira Gabriela Ciacco da Silva}

Avaliação de impacto ambiental de projetos de mineração no Estado de São Paulo: a etapa de acompanhamento. São Paulo, 2001.

$283 p$.

Tese (Doutorado) - Escola Politécnica da Universidade de São Paulo. Departamento de Engenharia de Minas.

1. Impacto ambiental - Avaliação 2. Mineração - Aspectos ambientais I. Universidade de São Paulo. Escola Politécnica. Departamento de Engenharia de Minas. II. $t$ 
Para Lajolo, Ivan, Mariana, Luísa e Maira. 



\section{AGRADECIMENTOS}

- à Fundação de Amparo à Pesquisa no Estado de São Paulo - Fapesp, pela concessão da bolsa de estudos, sem a qual teria sido impossível dedicar-me a esta pesquisa;

- ao Prof. Dr. Luis Enrique Sánchez, pela orientação competente, segura e amiga, assim como pelo exemplo a ser seguido;

- $\quad$ ao Prof. Dr. Arthur Pinto Chaves, pelo apoio e orientação no início da pesquisa;

- ao Prof. Dr. Sérgio Médici de Eston, pelo apoio, incentivo e amizade dispensados nestes anos de estudo;

- ao assessor ad hoc da Fapesp, pelo acompanhamento atento do desenvolvimento da pesquisa e pelas valiosas recomendações;

- aos professores e funcionários do Departamento de Engenharia de Minas da Epusp, pela acolhida e apoio;

- aos órgãos públicos, em especial ao Departamento de Avaliação de Impacto Ambiental - Daia, Companhia Estadual de Tecnologia de Saneamento Ambiental Cetesb e Departamento Estadual de Proteção de Recursos Naturais - DEPRN, que abriram seus acervos para consulta;

- às empresas de mineração, que forneceram preciosas informações para a pesquisa, seja por meio de entrevistas, seja em visitas técnicas;

- à Maria Cristina Martinez Bonesio, bibliotecária do Departamento de Engenharia de Minas da Epusp, pela ajuda competente e amigável na pesquisa e revisão das referências bibliográficas;

- à Débora Fiuza de Figueiredo Orsi, pela revisão atenta e competente dos textos;

- $\quad$ aos ex-colegas e amigos do IPT e Daia, pelo incentivo e apoio em vários momentos;

- aos colegas de pós-graduação da Epusp, com quem tive a oportunidade de trocar valiosas experiências; 



\section{SUMÁRIO}

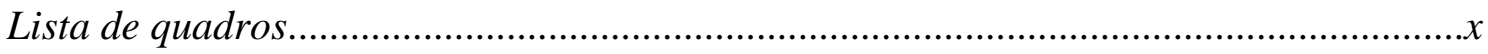

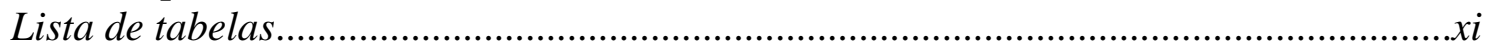

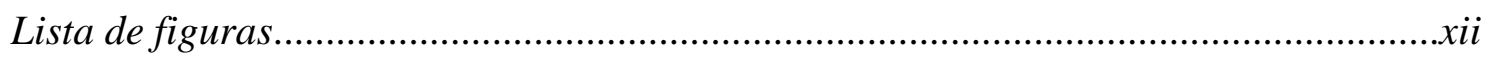

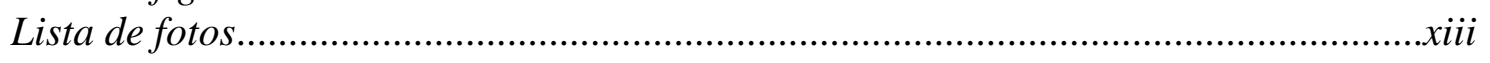

Lista de abreviaturas ou siglas................................................................................

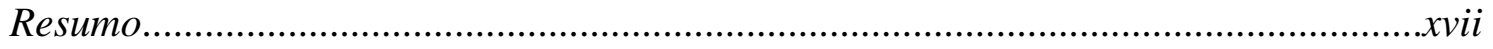

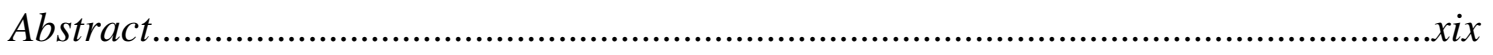

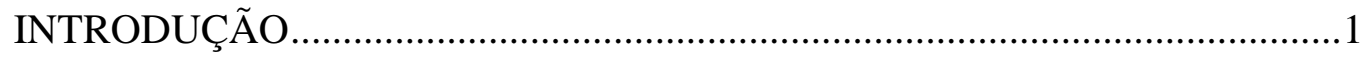

Capítulo 1

AVALIAÇÃ̃ DE IMPACTO AMBIENTAL .............................................

1.1 A natureza da AIA e seus papéis ................................................................11

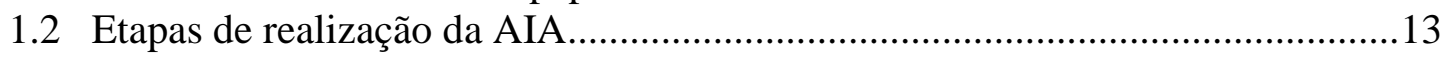

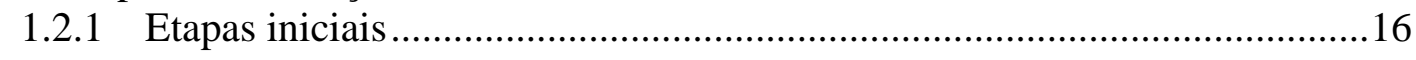

1.2.2 Análise detalhada...................................................................... 18

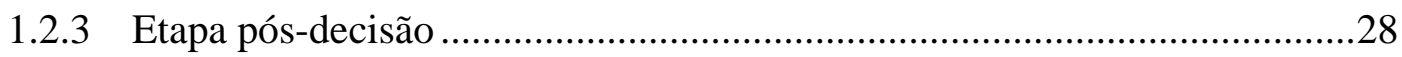

1.3 Outros instrumentos de avaliação ambiental ..................................................

$1.3 .1 \quad$ Avaliação de impactos cumulativos ...............................................

1.3.2 Avaliação ambiental estratégica (AAE) ............................................35

Capítulo 2

AVALIAÇÃO DE IMPACTO AMBIENTAL NO BRASIL ...........................39

$2.1 \quad$ Evolução da proteção jurídica ao meio ambiente no Brasil .............................39

2.2 AIA no Brasil: legislação disciplinadora....................................................

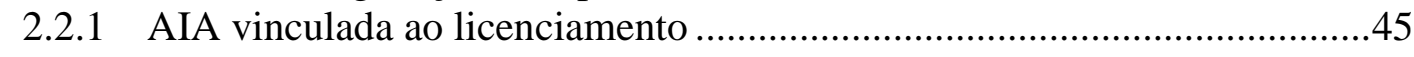

2.2 .2 Ações que devem ser submetidas ao processo de AIA ..............................47

2.2 .3 Conteúdo do EIA e do Rima .............................................................49

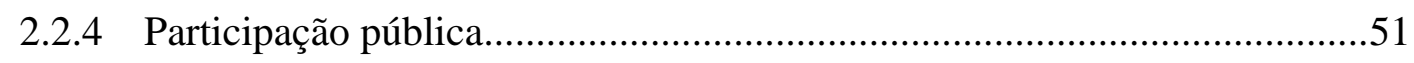

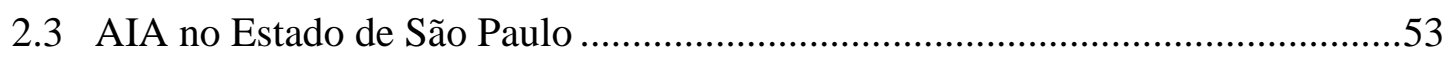

$2.3 .1 \quad$ A criação da Secretaria do Meio Ambiente (SMA) ................................54

2.3 .2 Os procedimentos de AIA em São Paulo ...............................................62

2.4 Procedimentos de AIA aplicados à mineração no Estado de São Paulo .............69

2.4.1 A Resolução SMA n ${ }^{0}$ 26/93 e a evolução dos critérios de triagem..............71

2.4 .2 AIA aplicada a múltiplos projetos de mineração e zoneamento minerário.74 
2.4.3 Principais normas legais incidentes sobre a atividade de mineração no

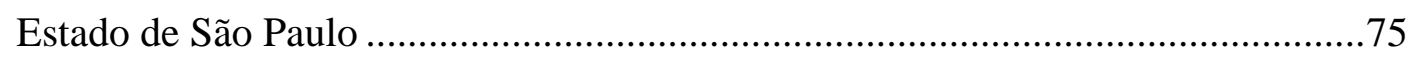

Capítulo 3

A MINERAÇÃO NO ESTADO DE SÃO PAULO E SEUS IMPACTOS NO

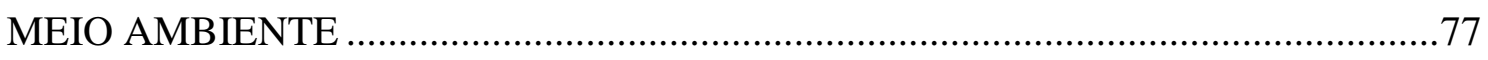

$3.1 \quad$ A Mineração e o Desenvolvimento Sustentável................................................79

3.2 O Setor Mineral Paulista ...................................................................... 82

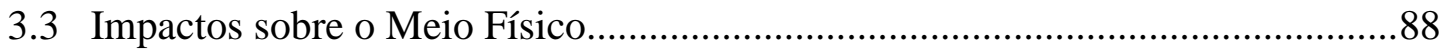

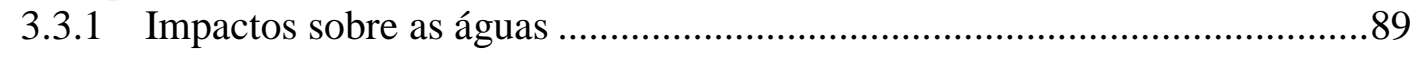

3.3.2 Resíduos sólidos ........................................................................94

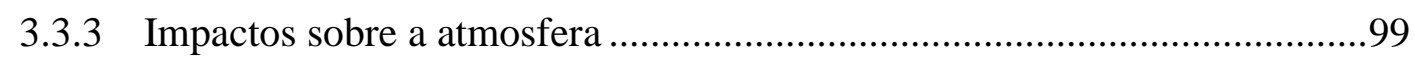

3.3.4 Vibrações no solo causadas pelo desmonte por explosivos ....................111

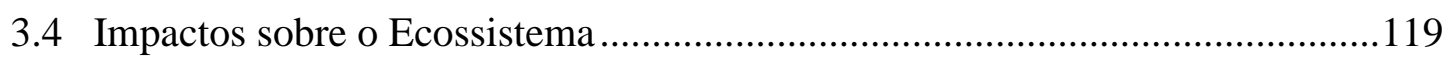

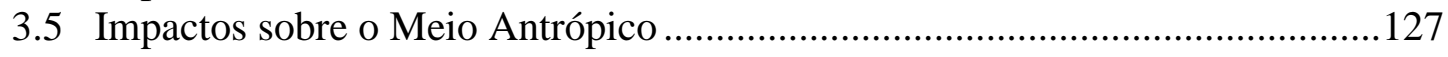

Capítulo 4

O UNIVERSO DA PESQUISA E A SELEÇÃO DE CASOS PARA ESTUDO

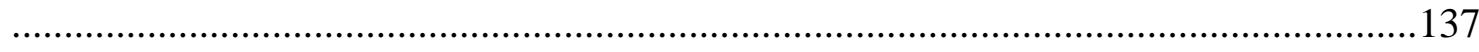

$4.1 \quad$ A AIA em São Paulo desde 1987 ....................................................... 138

$4.2 \quad$ Os EIAs de mineração aprovados...................................................... 141

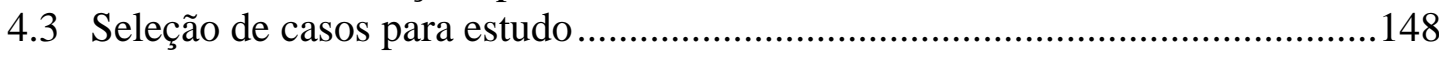

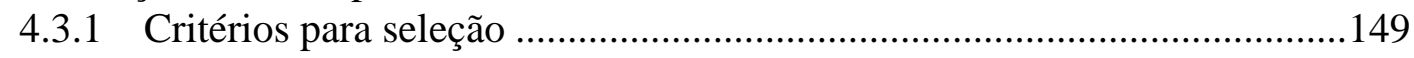

$4.3 .2 \quad$ Escolha final de casos para estudo ................................................151

Capítulo 5

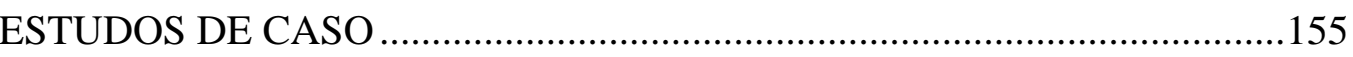

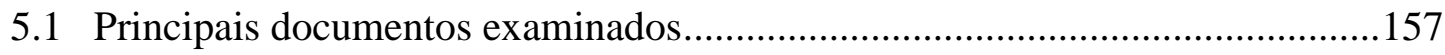

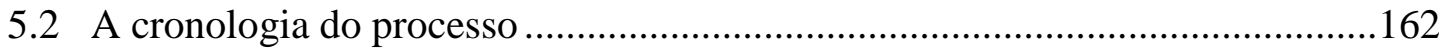

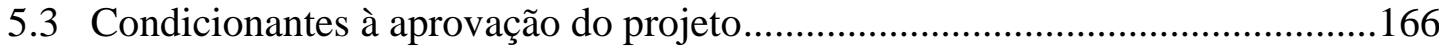

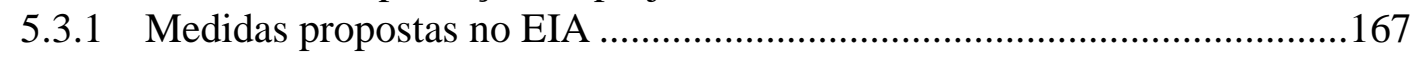

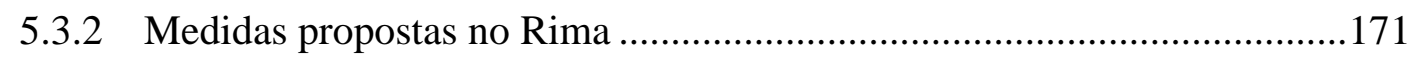

$5.3 .3 \quad$ Medidas propostas no relatório complementar...................................171

$5.3 .4 \quad$ Medidas registradas no parecer do Daia...........................................173

$5.3 .5 \quad$ Medidas expressas na deliberação do Consema .....................................177

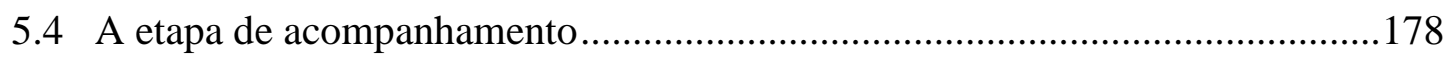

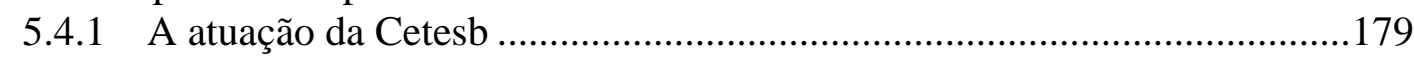

$5.4 .2 \quad$ A atuação do DEPRN ................................................................. 185 
$5.4 .3 \quad$ A atuação do Daia ..............................................................................187

$5.4 .4 \quad$ A atuação do Dusm ..................................................................... 188

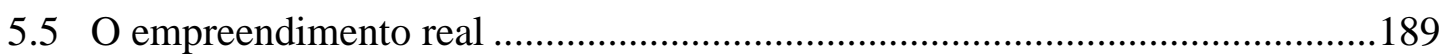

Capítulo 6

AS DEFICIÊNCIAS NA ETAPA DE ACOMPANHAMENTO: SUAS

ORIGENS E CAMINHOS PARA O APRIMORAMENTO .....................................195

$6.1 \quad$ Etapa de acompanhamento ..................................................................... 196

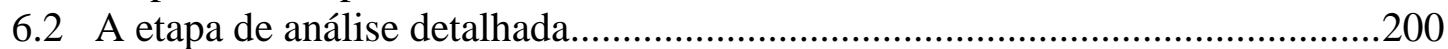

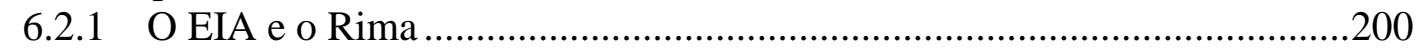

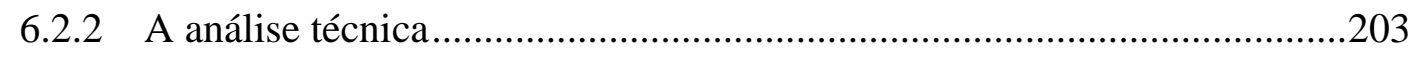

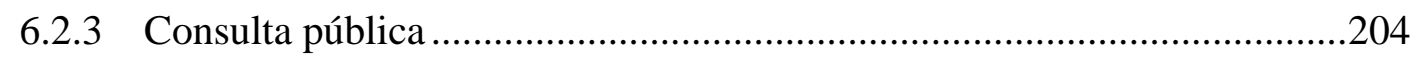

6.2.4 Decisão ...........................................................................................205

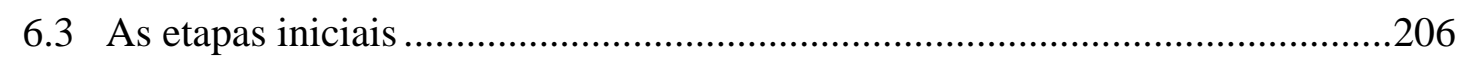

6.4 Caminhos para o aperfeicoamento da etapa de acompanhamento ...................208

$6.4 .1 \quad$ Fortalecimento do processo de AIA .............................................208

6.4 .2 Aprimoramento dos mecanismos de triagem ...................................212

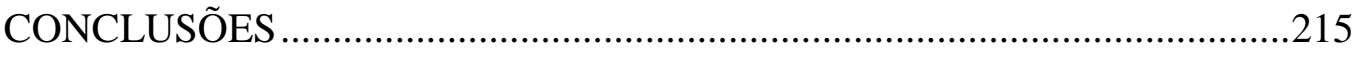

ANEXOS

ANEXO A: Modelo de ficha utilizada para o levantamento de dados os EIAs

de mineração aprovados no Estado de São Paulo desde 1986

ANEXO B: Dados coletados sobre os EIAs de mineração aprovados no

Estado de São Paulo desde 1986

ANEXO C: Roteiro e ficha para coleta de dados

ANEXO D: Documentação fotográfica

REFERÊNCIAS 


\section{Lista de quadros}

Quadro 1.1: Definições de avaliação de impacto ambiental

Quadro 1.2: Critérios de significância do US Council on Environmental

Quality..... 17

Quadro 1.3: Princípios da avaliação de impactos cumulativos .......................................34

Quadro 1.4: Tipologias de AAE mais freqüentes ..................................................... 37

Quadro 2.1: Instrumentos legais de administração dos recursos naturais ......................40

Quadro 2.2: Normas sobre exigência de EIA/Rima no Estado de São Paulo ..................66

Quadro 2.3: Principais normas legais incidentes sobre a atividade de mineração no Estado de São Paulo .............................................................................75

Quadro 3.1: Produção mundial de alguns minerais em 1990 .......................................78

Quadro 3.2: Indústrias que mais causam danos ao meio ambiente ...............................78

Quadro 3.3: Minerais de uso na construção civil produzidos no Estado de

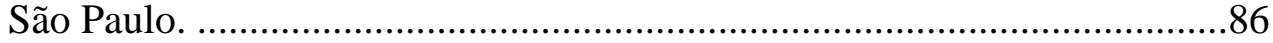

Quadro 3.4: Poluentes das águas mais comuns em mineração ....................................91

Quadro 3.5: Principais fontes de particulados em mineração e seu controle.................103

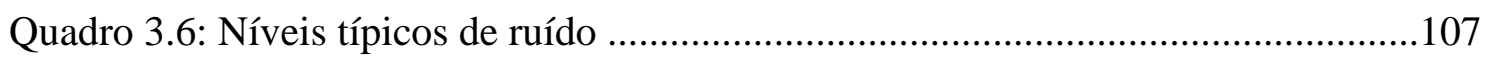

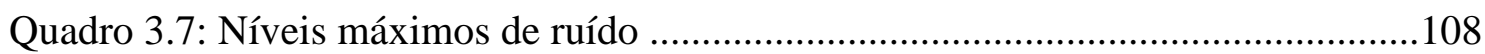

Quadro 3.8: Limites de vibração de partículas ............................................................113

Quadro 3.9: Nível seguro de vibrações para estruturas residenciais ............................113

Quadro 3.10: Principais impactos da mineração sobre o meio antrópico .....................128

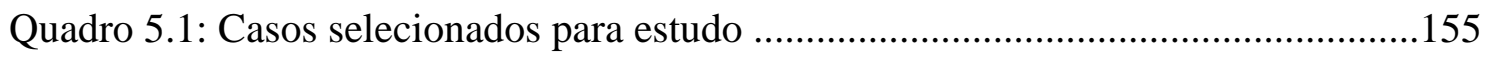

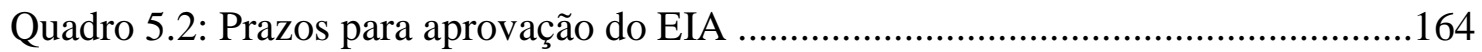

Quadro 5.3: Prazos para a emissão das licenças de instalação e de funcionamento ....165 


\section{Lista de tabelas}

Tabela 3.1: Valor da produção mineral brasileira em 1996, por unidade da federação e classe de substância (em R \$ 1.000,00)

Tabela 3.2: Quantidade e valor das substâncias minerais produzidas no Estado de São Paulo em 1996

Tabela 4.1: EIAs apresentados no período de janeiro/87 a dezembro/97, por tipo de projeto.

Tabela 4.2: Evolução do número de EIAs apresentados desde 1987, por tipo de projeto.

Tabela 4.3: Participação da mineração no total de EIAs apresentados no período de janeiro/87 a dezembro/97

Tabela 4.4: Evolução do número de EIAs na Secretaria do Meio Ambiente, por situação.

Tabela 4.5: Evolução do número de EIAs de mineração na Secretaria do Meio Ambiente, por situação.

Tabela 4.6: Evolução da apresentação e aprovação de EIAs de mineração

Tabela 4.7: EIAs de mineração aprovados por substância mineral

Tabela 4.8: EIAs de mineração aprovados, por região administrativa e substância produzida.

Tabela 4.9: Ordenação de casos para estudo, por substância mineral explorada. ........154

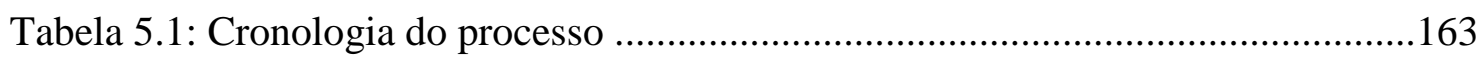

Tabela 5.2: Medidas propostas no EIA e sua localização no documento ......................167

Tabela 5.3: Medidas propostas no EIA e sua classificação quanto à formulação .........171

Tabela 5.4: Medidas propostas no relatório complementar e sua classificação quanto à formulação

Tabela 5.5: Medidas propostas no parecer do Daia e sua classificação quanto à formulação

Tabela 5.6: Exigências formuladas na licença de instalação (LI) 


\section{Lista de figuras}

Figura 1.1: Processo de avaliação de impacto ambiental ...............................................15

Figura 1.2: Participação pública nas decisões ............................................................24

Figura 1.3: Planejamento e avaliação de impacto ambiental .........................................36

Figura 2.1: Organograma da Secretaria do Meio Ambiente ..........................................54

Figura 3.1: Ciclo de vida dos minerais e metais ..........................................................81

Figura 3.2: Distribuição da produção mineral paulista em 1996, em valor ....................84

Figura 3.3: Macrocompartimentação geológica do Estado de São Paulo. ......................86

Figura 3.4: Pólos produtores de matérias-primas minerais de uso na construção civil no Estado de São Paulo ..................................................................88

Figura 3.5: Remanescentes Florestais da Mata Atlântica em 1995 ...............................126

Figura 4.1: Evolução do número de EIAs de mineração e de outros projetos no período jan/87 a dez/97 ...........................................................................139

Figura 4.2: Evolução dos prazos de análise por data da aprovação ................................144

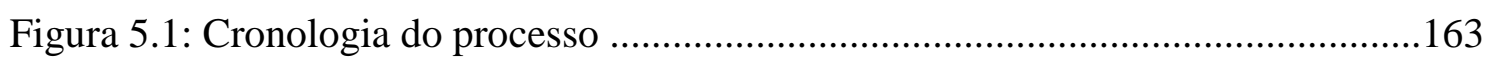

Figura 5.2: Distribuição geral dos prazos de aprovação de EIA e emissão das licenças ambientais .166 


\section{Lista de fotos}

FOTO 1 - Aspectos de cortinas vegetais que circundam empreendimento.

FOTO 2 - Caixa de decantação de finos, utilizada para clarificação de águas provenientes de pilhas de areia.

FOTO 3 - Armazenagem de combustíveis próximo de linha d'água, em área de inundação, além de equipamentos em manutenção.

FOTO 4 - Área de operação de empreendimento próxima de linha d'água e de pilar de ponte.

FOTO 5 - Material fino sedimentado é retirado de caixa de decantação e em seguida depositado em pilha próxima de linha d'água, em área de APP.

FOTO 6 - Vista geral de empreendimento. No centro da foto, destaca-se a área utilizada para deposição temporária de material fino retomado de caixa de decantação.

FOTO 7 - Barreira vegetal formada com essências nativas.

FOTO 8 - Essências nativas plantadas como medida de enriquecimento de vegetação ciliar.

FOTO 9 - Acúmulo de material úmido depositado sob correia transportadora devido à ação de aspersão de água sobre poeira.

FOTO 10 - Caminhão-pipa em funcionamento.

FOTO 11 - Detalhe de sistema de iniciação não-elétrica por tubo de choque ("espoleta Exel") e de furo tamponado com material fino.

FOTO 12 - Vegetação rasteira de crescimento espontâneo, capim napier e algumas árvores plantadas para a proteção de talude sujeito à erosão e escorregamentos, próximo à drenagem e contígüo à mata nativa.

FOTO 13 - Panorâmica de frente de lavra onde se observa que o capeamento do depósito é pouco espesso e constituído de solo fértil.

FOTO 14 - Espessador utilizado para clarificar efluentes de usina de beneficiamento, possibilitando redução do número de lagoas de sedimentação.

FOTO 15 - Vista pelo lado de fora, a "cerca-viva" deveria mitigar a ocorrência de poeiras fugitivas, ruído e degradação visual.

FOTO 16 - Vista, a partir de área de expedição da mina, de aglomerado de casas de propriedade de fazendeiro de quem área de empreendimento é arrendada.

FOTO 17 - Água acumulada à beira de via interna em razão de obstrução de canaletas de drenagem por falta de limpeza.

FOTO 18 - Bacia (lagoa) de drenagem para decantação de finos totalmente assoreada.

FOTO 19 - Chuveiro para lavagem de brita para expedição e água correndo em direção ao corpo d'água.

FOTO 20 - Água de lavagem de brita correndo em direção ao corpo d'água.

FOTO 21 - Córrego que margeia propriedade junto de área de britagem recebe água de lavagem de brita e águas de drenagem superficial em geral.

FOTO 22 - Transbordamento de caixa separadora de óleos e graxas instalada próximo da oficina e galpão para lavagem de máquinas e veículos.

FOTO 23 - Água proveniente de transbordamento da caixa separadora de óleos e graxas anexa à oficina e galpão para lavagem de máquinas e veículos. 


\section{LISTA DE ABREVIATURAS E SIGLAS}

AAE - Avaliação Ambiental Estratégica

Abes - Associação Brasileira de Engenharia Sanitária e Ambiental

ABNT - Associação Brasileira de Normas Técnicas

AIA - Avaliação de Impacto Ambiental

Aimea - Associação das Indústrias de Mineração de Areia do Vale do Paraíba

AMB - Anuário Mineral Brasileiro

CCOM - Coordenadoria de Comunicação

Ceam - Coordenadoria de Educação Ambiental

CEQ - Council on Environmental Quality

Cetesb - Companhia Estadual de Tecnologia de Saneamento Ambiental

Cinp - Coordenadoria de Informações Técnicas, Documentação e Pesquisa Ambiental

CNUMAD - Conferência das Nações Unidas sobre o Meio Ambiente

Conama - Conselho Nacional do Meio Ambiente

Consema - Conselho Estadual do Meio Ambiente

CPLA - Coordenadoria de Planejamento Ambiental

CPRN - Coordenadoria de Licenciamento Ambiental e de Proteção de Recursos

Naturais

Crea - Conselho Regional de Engenharia, Arquitetura e Agronomia

DAEE - Departamento de Águas e Energia Elétrica

Daia - Departamento de Avaliação de Impacto Ambiental

DEPRN - Departamento Estadual de Proteção de Recursos Naturais

DNPM - Departamento Nacional da Produção Mineral

DPLAN - Diretoria de Planejamento Ambiental

DPRN - Divisão de Proteção de Recursos Naturais

Dusm - Departamento de Licenciamento e Fiscalização do Uso do Solo Metropolitano

ECP - Equipamento de Controle de Poluição

EIA - Estudo de Impacto Ambiental

EIS - Environmental Impact Assessment

Emplasa - Empresa Metropolitana de Planejamento da Grande São Paulo

EPA - Environmental Protection Agency

Epusp - Escola Politécnica da Universidade de São Paulo 
EUA - Estados Unidos da América

Fapesp - Fundação de Amparo à Pesquisa do Estado de São Paulo

Fiesp - Federação das Indústrias do Estado de São Paulo

GACP - Gerência de Análise e Controle de Projetos

Gaia - Gerência de Avaliação de Impacto Ambiental

Grapohab - Grupo de Aprovação de Projetos Habitacionais

Hivol - High Volume Sampler

IAB - Instituto dos Arquitetos do Brasil

IAIA - International Association for Impact Assessment

Ibama - Instituto Brasileiro do Meio Ambiente e dos Recursos Naturais

Inpe - Instituto Nacional de Pesquisas Espaciais

IPT - Instituto de Pesquisas Tecnológicas do Estado de São Paulo

ISA - Instituto Socioambiental

LF - Licença de Funcionamento

LI - Licença de Instalação

LO - Licença de Operação

LP - Licença Prévia

MCE - Memorial de Caracterização do Empreendimento

Nepa - National Environmental Policy Act

NPS - Nível de Pressão Sonora

OAB - Ordem dos Advogados do Brasil

ONG - Organização Não-Governamental

PCA - Plano de Controle Ambiental

PND - Plano Nacional de Desenvolvimento

Prad - Plano de Recuperação de Área Degradada

RAL - Relatório Anual de Lavra

RAP - Relatório Ambiental Preliminar

RCA - Relatório de Controle Ambiental

Rima - Relatório de Impacto Ambiental

RMSP - Região Metropolitana de São Paulo

ROD - Record of Decision

SAA - Superintendência de Avaliação Ambiental

SAR - Secretaria das Administrações Regionais 
SBPC - Sociedade Brasileira para o Progresso da Ciência

SDHU - Secretaria de Desenvolvimento Habitacional e Urbano

SEA - Strategic Environmental Assessment

Sisema - Sistema Estadual do Meio Ambiente

Sisnama - Sistema Nacional do Meio Ambiente

SMA - Secretaria do Meio Ambiente

SNM - Secretaria dos Negócios Metropolitanos

Soma - Secretaria de Obras e do Meio Ambiente

Spam - Sistema de Planejamento e de Administração Metropolitana

TR - Termo de Referência

Unesp - Universidade Estadual Paulista "Júlio de Mesquita Filho"

Unicamp - Universidade Estadual de Campinas

USBM - United States Bureau of Mines

USEPA - United States Environmental Protection Agency

USP - Universidade de São Paulo

VLE - Ventilação Local Exaustora

ZEI - Zona de Uso Estritamente Industrial

ZUD - Zona de Uso Diversificado

ZUD - Zona de Uso Diversificado

Zupi - Zona de Uso Predominantemente Industrial 


\section{RESUMO}

Desde a regulamentação dos procedimentos de avaliação de impacto ambiental (AIA), em meados dos anos oitenta, numerosos projetos de mineração foram avaliados, aprovados e licenciados no Estado de São Paulo, consumindo grande parte dos escassos recursos humanos e materiais disponíveis para análise técnica de estudos ambientais. Pouco se sabe, no entanto, sobre os resultados efetivamente alcançados com a aplicação do novo instrumento de gestão ambiental.

Esta pesquisa teve como propósito geral avaliar a eficácia da aplicação dos procedimentos de AIA aos projetos de mineração no Estado de São Paulo. O foco principal da análise foi a etapa de acompanhamento, ou mais precisamente, a atuação dos órgãos governamentais no sentido de garantir a correta implementação do projeto, bem como do programa de gerenciamento ambiental definido no processo de AIA como condicionante à outorga da licença.

Analisaram-se em profundidade seis casos escolhidos entre os estudos de impacto ambiental aprovados no Estado no período compreendido entre os anos de 1987 e 1997. Em cada caso estudado, examinaram-se todos os documentos e registros administrativos disponíveis nos principais órgãos de governo que participam do processo de AIA. Esta tarefa objetivou principalmente (1) obter dados sobre cada projeto; (2) pesquisar todas as medidas mitigadoras e outras medidas de gerenciamento ambiental propostas e incorporadas aos termos e condições de aprovação do projeto; e (3) verificar as ações de controle executadas após a aprovação do projeto. Complementarmente, visitaram-se as minas para observação das condições de implementação dos projetos e das medidas de gerenciamento ambiental.

Os resultados do estudo confirmaram largamente suas hipóteses iniciais de que a implementação dos projetos é falha e compromete severamente o processo. Concluiu-se, ainda, que esta situação decorre não somente das deficiências dos órgãos fiscalizadores, incapazes de garantir o cumprimento dos termos e condições estabelecidos na aprovação do estudo de impacto ambiental, mas de uma cadeia de imperfeições que atinge praticamente todas as atividades do processo de AIA. 
Para superar as deficiências da etapa de acompanhamento, propõem-se, portanto, intervenções nas várias etapas do processo, que deve ser aprimorado e fortalecido, sob pena de transformar-se um poderoso instrumento de gestão como a avaliação de impacto ambiental em apenas mais um obstáculo em meio às já enormes dificuldades burocráticas impostas para a regularização de empreendimentos de mineração. 


\section{ABSTRACT}

Since procedures of environmental impact assessment (EIA) were regulated in Brazil, in the mid eighties, numerous mining projects have been assessed, approved and granted environmental permits in the State of São Paulo, draining a great part of the scarce human and material resources available for reviewing environmental studies. Notwithstanding, there are few data concerning the actual results achieved by this new environmental management tool.

This research aimed at evaluating the effectiveness of the EIA procedures applied to mining projects in the State of São Paulo. The analysis focused mainly on the follow-up phase, or more precisely, on the government branches' performance in enforcing the proper implementation of terms and conditions of project approval.

The study examined in full detail six cases selected among the environmental impact studies approved in the State of São Paulo between 1987 and 1997. In each case studied, all the documents and administrative records of relevant government organisms that take part in the EIA process have been reviewed. This task aimed mainly at (1) obtaining data on each project, (2) surveying all mitigation and other management measures proposed and incorporated into the terms and conditions of project approval and (3) checking the control actions performed after project approval. Additionally, site visits were carried out in order to check the implementation of the project and the environmental management measures.

The study widely confirmed its initial hypothesis that the implementation of mining projects is actually faulty, severely harming the whole process. The research also showed that this situation is not uniquely due to the weak performance of the surveillance agency, which is not able to enforce the terms and conditions of project approval, but also because of several imperfections that pervade most of the EIA process activities.

To overcome the deficiencies in the follow-up phase, changes are proposed in several steps of the process, which should be improved and strengthened. If not, a 
powerful management tool as the environmental impact assessment is endangered to be transformed in just one more obstacle among the already enormous bureaucratic hindrances imposed to mining projects regularization. 


\section{INTRODUÇÃO}

Os procedimentos de avaliação de impacto ambiental (AIA) foram estabelecidos formalmente pela primeira vez em uma jurisdição em 1970, quando o presidente dos Estados Unidos sancionou o National Environmental Policy Act, mais conhecido pela sigla NEPA, aprovado pelo congresso daquele país no ano anterior. Desde essa data, com variações e adaptações em diversos níveis, a AIA disseminou-se amplamente e nos dias atuais é adotada em cerca de duzentas jurisdições em todo o mundo.

Concebida como instrumento de avaliação das conseqüências futuras das ações humanas sobre o meio ambiente, a AIA logrou incorporar as variáveis de caráter ambiental aos processos decisórios, tanto no âmbito das empresas como no do poder público, ao lado dos parâmetros técnicos e econômicos já tradicionalmente considerados em planejamento. Mais do que um instrumento, a AIA consolidou-se como um processo, que se inicia com a seleção das ações às quais deve ser aplicada e, nos casos em que a decisão final é favorável ao projeto ou ação proposta, acompanha sua implementação, operação e desativação.

Três décadas de prática de avaliação de impacto ambiental em várias partes do mundo consolidaram os elementos gerais que constituem o processo, os quais podem ser agrupados em três grandes estágios: (i) etapas iniciais, quando se define o tipo de estudo ambiental a que deve ser submetida a proposta; (ii) análise detalhada, que engloba desde a execução do estudo de impacto ambiental até sua análise e tomada de decisão, com a necessária participação pública; e (iii) etapa pós-aprovação, que inclui o monitoramento dos impactos ambientais e medidas mitigadoras, assim como programas de gestão ambiental e auditoria.

No princípio, a AIA era aplicada apenas a projetos e obras, mas, com o tempo, esta restrição revelou-se inadequada em diversas situações e o instrumento ganhou novos contornos. Disseminou-se, por exemplo, a convicção de que a avaliação de impacto ambiental deveria ser conduzida o mais cedo possível no processo decisório. 
Daí surgiu a avaliação ambiental estratégica (AAE), ou seja, a avaliação ambiental de políticas, planos e programas. Outra limitação da AIA aplicada a projetos, a dificuldade de avaliar consequiências ambientais de múltiplas causas, como vários projetos que acarretam impactos ambientais individualmente insignificantes, porém significativos em seu conjunto, deu origem ao instrumento avaliação de impactos cumulativos, que integra e avalia o resultado das atividades de vários agentes em um determinado contexto.

Passados mais de dez anos do seu surgimento nos Estados Unidos, a AIA começou a ser introduzida no Brasil no início dos anos oitenta. Embora precedida por outros dispositivos legais de menor alcance territorial ou temático e por algumas experiências pioneiras realizadas por exigência de órgãos internacionais de financiamento de projetos de desenvolvimento, a Lei da Política Nacional do Meio Ambiente, Lei Federal $\mathrm{n}^{\mathrm{o}}$ 6938, de 31 de agosto de 1981, é reconhecida como o principal marco na introdução da AIA no Brasil. Sua promulgação culminou com um processo de evolução da legislação brasileira de proteção ao meio ambiente, que se iniciou com os dispositivos de proteção aos recursos naturais, nos anos trinta; evoluiu nos anos setenta para o controle da poluição, cujo imperativo se fez sentir com o agravamento dos problemas ambientais decorrentes da rápida industrialização e urbanização dos País; e incorporou, no início dos anos oitenta, os conceitos de planejamento territorial, com as leis de proteção aos mananciais e zoneamento urbano, entre outras.

Nos termos da Lei da Política Nacional do Meio Ambiente, a AIA aportou no Brasil sem qualquer limitação ou condicionante, podendo alcançar projetos públicos ou privados, urbanos ou rurais, industriais ou não. Do mesmo modo, sua aplicação não está restrita a obras e atividades, podendo atingir níveis mais elevados de decisão como políticas, planos e programas. Posteriormente à promulgação desta lei, no entanto, os dispositivos que a regulamentaram - Decreto $n^{-0}$ 88.351/83, Decreto $n^{0}$ 99.274/90 e Resolução Conama $\mathrm{n}^{\mathrm{o}}$ 1/86 - estabeleceram um vínculo entre a AIA e o licenciamento ambiental, subordinando aquela a este. Com isso, restringiram o alcance deste instrumento de política ambiental e deixaram de incluir as políticas, planos e programas em seu âmbito de aplicação. 
Com relação às ações que teriam de ser submetidas ao processo de AIA, a Resolução Conama n⿳o 1/86, ao determinar que o licenciamento de atividades modificadoras do meio ambiente dependeria de elaboração de estudo de impacto ambiental, incluiu em seu texto uma listagem cujo caráter, exemplificativo ou taxativo, passou a ser objeto de controvérsias que dificultaram e postergaram a adoção de critérios e procedimentos de triagem. Uma das atividades listadas na Resolução Conama $\mathrm{n}^{\mathrm{o}} 1 / 86$ foi a extração e beneficiamento de minerais.

A inclusão da mineração entre as atividades cujo licenciamento ambiental dependeria de avaliação de impacto ambiental provocou forte repercussão sobre os diversos segmentos atuantes no setor mineral. Mesmo no Estado de São Paulo, onde o sistema de licenciamento ambiental vigorava desde meados dos anos setenta, incluindo a extração e o beneficiamento de minerais entre as chamadas fontes de poluição sujeitas ao licenciamento ambiental, a nova sistemática alterou profundamente as relações entre o governo, os empreendedores e a sociedade organizada.

Ocorre que a atividade já era fortemente regulamentada, até por força do preceito constitucional que inclui os recursos minerais entre os bens da União, e seu aproveitamento já dependia de um conjunto de procedimentos notoriamente complexos e morosos. As partes interessadas estavam, no entanto, razoavelmente adaptadas, pois ao lado das enormes dificuldades burocráticas impostas para a regularização de um empreendimento mineiro, figurava um sistema de fiscalização tão precário que a operação de minas em situação irregular era a situação mais comum.

Os procedimentos para o licenciamento ambiental de minas, porém, quando comparados aos necessários para a obtenção de autorizações e concessões dos órgãos gestores de recursos minerais, eram notavelmente mais simples e expeditos. A fiscalização por parte dos órgãos ambientais tampouco era exigente com o setor mineral, já que, em decorrência de características da economia do Estado, predominantemente apoiada em atividades industriais, o sistema de controle ambiental consolidou procedimentos dirigidos apenas para o controle deste tipo de poluição. Deste modo, numerosos empreendimentos de mineração instalaram-se no Estado sem o respaldo das licenças ambientais e, mesmo assim, operaram por vários anos com raras intervenções dos órgãos de controle ambiental. 
Para que estes empreendimentos, instalados irregularmente, não fossem privilegiados em relação aos novos empreendimentos, a Secretaria do Meio Ambiente (SMA) de São Paulo, ao regulamentar a aplicação dos procedimentos de AIA ao licenciamento de empreendimentos mineiros, estendeu a exigência de avaliação de impacto ambiental aos empreendimentos já instalados que não estivessem regularizados perante a Companhia Estadual de Tecnologia de Saneamento Ambiental (Cetesb). Deste modo, além dos empreendimentos novos e das ampliações, passou a depender de aprovação de estudo de impacto ambiental o licenciamento corretivo de empreendimentos em funcionamento ao arrepio da lei.

Além disso, apesar de expresso na Constituição Federal (Art. 225, § 1º̣, item IV) que a exigência de estudo prévio de impacto ambiental aplica-se apenas à instalação de obra ou atividade potencialmente causadora de significativa degradação do meio ambiente, em São Paulo passou-se a exigir estudo de impacto ambiental (EIA) de todos os empreendimentos em processo de licenciamento, independentemente da natureza do bem mineral, do porte da atividade, método de extração e beneficiamento ou localização do projeto. Como decorrência desta orientação, a mineração rapidamente assumiu a dianteira como atividade com maior número de EIAs apresentados ao órgão ambiental paulista.

Esta posição de destaque, que perdurou há até bem pouco tempo, é considerada desproporcional ao potencial de agressão ao meio ambiente representado pelo setor mineral paulista. Embora este potencial não possa de modo algum ser visto como negligenciável, em virtude de seu caráter cumulativo associado à localização de suas minas - agrupadas em pólos de produção e próximas de centros urbanos - não existem em São Paulo grandes minerações, tampouco minas de minerais radioativos ou com alto potencial de geração de drenagem ácida, ou seja, empreendimentos cujos impactos ambientais são consensualmente avaliados como significativos.

Com o propósito de corrigir esta distorção, grandes esforços foram envidados na proposição e aprimoramento de critérios e procedimentos para a triagem dos projetos que deveriam ser submetidos ao processo completo de AIA. Também a etapa de análise detalhada, que inclui o desenvolvimento do estudo de impacto ambiental, progrediu consideravelmente com o ganho de experiência das empresas de consultoria e das equipes encarregadas da análise. A etapa pós-aprovação do EIA, no entanto, é motivo 
de especial preocupação, uma vez que no quadro institucional brasileiro, em particular no caso da mineração em São Paulo, há evidências de um grande descolamento entre o projeto teórico - proposto, discutido, negociado e aprovado no âmbito do processo de AIA - e o empreendimento real, instalado e em operação.

A preocupação com a etapa pós-aprovação não é exclusiva de São Paulo ou do Brasil e também não se restringe aos projetos de mineração. Na verdade, desde a criação do instrumento avaliação de impacto ambiental, numerosos estudos sobre sua eficácia foram conduzidos em todo o mundo, porém bem poucos focalizaram esta etapa. Sua importância, no entanto, é inquestionável, já que a identificação, previsão e avaliação de impactos ambientais é caracterizada por incertezas inerentes ao caráter prévio dos estudos. Na implementação do projeto podem ocorrer impactos inesperados ou de magnitude diferente da prevista; as medidas mitigadoras podem não ser tão eficientes quanto se esperava; o projeto pode sofrer alterações que resultem em nova relação com o meio. Pode ocorrer, ainda, que o proponente não implemente as medidas mitigadoras elencadas no EIA ou o faça de maneira inadequada ou insuficiente.

Assim, a continuidade do processo de AIA após a etapa de decisão final é necessária sob dois pontos de vista principais: (i) técnico-científico, e (ii) legaladministrativo. Do ponto de vista técnico-científico, permite aprimorar o conhecimento acerca das relações entre as ações humanas e suas consequiências sobre o meio ambiente e, desta forma, contribuir para a melhoria da qualidade de previsões futuras sobre empreendimentos similares.

Sob a ótica legal-administrativa, as atividades de acompanhamento da implementação do empreendimento devem ser capazes de garantir o cumprimento dos termos e compromissos assumidos no processo. Alterações no projeto ou nas medidas ambientais programadas, mesmo quando consentidas pelo órgão ambiental, são questionáveis nesta etapa. Sabe-se que licença ambiental, quando obtida com base em um processo de AIA, refere-se a um empreendimento com determinadas características, condicionado à implementação de um conjunto de medidas destinadas a atenuar seus impactos negativos e potencializar os positivos. Tais condicionantes são fixados por meio de um processo que envolve participação pública e decisão colegiada. Sendo assim, alterações no projeto ou nas medidas ambientais projetadas requereriam, em 
princípio, anuência das partes interessadas, sob pena de comprometer a validade da licença.

Enfim, mais do que em qualquer outra, deficiências na etapa de implementação do empreendimento podem comprometer a eficácia do processo de AIA. Ou seja, por mais bem elaborados que sejam os estudos ambientais e por mais bem conduzido que seja o processo decisório, de nada valerá o esforço se os compromissos assumidos não forem cumpridos.

Esta pesquisa teve como propósito geral avaliar a eficácia da aplicação dos procedimentos de AIA aos projetos de extração e beneficiamento de minerais no Estado de São Paulo e sugerir modificações para seu aperfeiçoamento. O foco principal desta análise foi a etapa pós-decisão, ou seja, o acompanhamento do programa de atenuação ou compensação dos impactos negativos, definido no processo de AIA como condicionante à outorga da licença ambiental, do ponto de vista dos órgãos governamentais responsáveis pela fiscalização de sua implementação.

O método utilizado foi o de estudo de caso, que embora não se preste à generalização estatística, uma vez que os casos em estudo não constituem uma amostra no sentido estatístico, ou seja, um número restrito de indivíduos capazes de representar toda a população, é adequado para a análise aprofundada de fenômenos associados ao contexto no qual se inserem. Foram analisados em profundidade seis casos escolhidos entre os 77 EIAs de mineração aprovados no Estado de São Paulo no período compreendido entre os anos de 1987 e 1997. Para cada caso estudado, foram examinados todos os documentos que compõem o processo de AIA e os processos de licenciamento ambiental e de fiscalização, e visitadas as minas para observação da implementação do projeto e das medidas ambientais.

O resultado da pesquisa é apresentado em seis capítulos. Os dois primeiros Avaliação de impacto ambiental e Avaliação de impacto ambiental no Brasil apresentam os fundamentos históricos e conceituais da AIA; as etapas de sua realização; sua introdução no Brasil; a legislação disciplinadora em nível federal; e as normas, procedimentos e órgãos envolvidos na aplicação da AIA no Estado de São Paulo, com ênfase nos projetos de mineração.

O terceiro capítulo - A mineração no Estado de São Paulo e seus impactos sobre o meio ambiente - discute os impactos ambientais e o conceito de 
desenvolvimento sustentável aplicado à mineração; apresenta as características do setor mineral paulista e faz uma revisão dos principais impactos que a mineração pode causar nos meios físico, biótico e antrópico, destacando-se aqueles mais comuns em pequenas e médias minerações com as características encontradas no Estado de São Paulo.

O quarto capítulo - O universo da pesquisa e a seleção de casos para estudo traz o resultado do inventário dos estudos de impacto ambiental apresentados à Secretaria do Meio Ambiente desde 1987 e um panorama geral dos EIAs de empreendimentos minerários aprovados desde aquela data, destacando a evolução dos prazos de análise. São discutidos e aplicados critérios para seleção de casos para estudo, resultando na escolha de seis casos.

No quinto capítulo - Estudos de caso - são descritos em detalhe os métodos de pesquisa aplicados aos seis casos selecionados, assim como os resultados obtidos. Tendo em vista compromissos assumidos com os responsáveis pelas minas estudadas, os resultados são reportados para o conjunto de casos, impossibilitando a identificação das minas e a correlação entre cada caso e os problemas observados.

No sexto capítulo - As deficiências na etapa de acompanhamento: suas origens e caminhos para o aprimoramento - faz-se a interpretação dos resultados, a generalização analítica dos problemas, apontam-se as causas e são propostas soluções.

No capítulo final - Conclusões - são destacadas as principais evidências reveladas pela pesquisa e as lições decorrentes, assim como são esboçadas algumas rotas a ser seguidas para o aperfeiçoamento dos procedimentos de AIA aplicados ao setor mineral no Estado de São Paulo. Tal aperfeiçoamento é necessário, sob pena do processo de AIA ser transformado em mero procedimento burocrático, vazio de conteúdo substantivo. 


\section{Capítulo 1}

\section{AVALIAÇÃO DE IMPACTO AMBIENTAL}

Os fundamentos do processo de avaliação de impacto ambiental (AIA) foram estabelecidos nos Estados Unidos no final de 1969 quando o Congresso aprovou o National Environmental Policy Act, mais conhecido pela sigla Nepa. Sancionado pelo presidente no ano seguinte, o Nepa era uma resposta às pressões crescentes da sociedade organizada para que os aspectos ambientais passassem a ser considerados na tomada de decisão sobre a implantação de projetos capazes de causar significativa degradação ambiental.

A lei americana estabeleceu uma política nacional do meio ambiente, atribuindo responsabilidades ao Governo Federal e fixando objetivos que revelavam claramente que o termo meio ambiente incluía, além dos componentes físicos e biológicos, aspectos sociais e culturais. Para garantir a consecução desses objetivos, a lei previu, em sua Seção 102, três importantes dispositivos a ser cumpridos por todas as agências federais (ORTOLANO, 1997):

a) utilizar uma abordagem interdisciplinar sistemática que assegure o uso das ciências naturais e sociais e das técnicas de projeto ambiental no planejamento e na tomada de decisões que possam causar impactos no ambiente humano;

b) identificar e desenvolver métodos e procedimentos que assegurem que valores ambientais não quantificados sejam adequadamente considerados na tomada de decisões, juntamente com os aspectos técnicos e econômicos; e

c) elaborar um relatório detalhado dos impactos ambientais para as ações federais importantes que afetem significativamente a qualidade do ambiente humano. Este dispositivo é considerado como o alicerce do sistema de proteção ambiental instituído na lei e resultou em avanços importantes na quantidade e qualidade das informações consideradas e difundidas previamente às decisões. 
É interessante destacar que nesse primeiro momento a avaliação de impacto ambiental passou a ser requerida apenas para as ações de responsabilidade do Governo Federal, porém alcançou não apenas os projetos governamentais, mas todas as suas decisões, programas, licenças, autorizações e empréstimos. A elaboração dos estudos ambientais era atribuição de governo, por intermédio de suas agências, e foi posteriormente regulamentada pelo US Council on Environmental Quality (CEQ), criado pela mesma lei para assessorar o presidente em assuntos relativos ao meio ambiente.

Mas os problemas ambientais associados ao desenvolvimento econômico não eram privativos dos Estados Unidos e a concepção de AIA, formalizada no Nepa e nos regulamentos do CEQ, difundiu-se mundialmente, sofrendo adaptações em diferentes níveis para ajustar-se ao sistema de governo de cada jurisdição (país, região, governo local) em que foi introduzida. Algumas jurisdições optaram pela introdução dos requisitos de AIA por meio de leis, enquanto outras, como Hong Kong (WOOD; COPPELL, 1999), apoiaram seu sistema de avaliação de impacto ambiental apenas em procedimentos administrativos em um primeiro momento, para somente anos depois editar leis.

Os primeiros países a aderir ao sistema introduzido pelos Estados Unidos, avaliação de impacto ambiental previamente às decisões governamentais importantes, foram o Canadá, a Nova Zelândia e a Austrália, ainda no início dos anos 70. SÁNCHEZ (1999) destaca como razões para esta rápida adesão o fato de estes países terem sido colônias britânicas e, como tal, haverem tido um modelo de desenvolvimento semelhante entre si, além de terem herdado um sistema jurídico e político semelhante. Conseqüentemente, além de apresentarem problemas ambientais similares em natureza e extensão, a adaptação do sistema era mais imediata. O mesmo não ocorreu com os países da Europa, onde o modelo americano não foi bem aceito no primeiro momento e o processo de AIA somente começou a se disseminar em 1985, quando a Comissão Européia emitiu uma resolução obrigando os países membros da então Comunidade Econômica Européia (atual União Européia) a adotar procedimentos formais de AIA para aprovar empreendimentos potencialmente causadores de significativa degradação ambiental. Como única exceção, já em 1976 a França havia introduzido a AIA no bojo do seu sistema de licenciamento. Diferentemente do modelo americano, neste país os 
estudos devem ser elaborados pelo proponente do projeto e a exigência atinge indústrias e outras atividades com potencial de causar impacto ambiental.

SÁNCHEZ (1999) destaca, ainda, como grande impulso para a difusão internacional da AIA, sua discussão na Conferência das Nações Unidas sobre o Meio Ambiente e Desenvolvimento (CNUMAD), a Rio 92, e a inclusão na Declaração do Rio do princípio: "A avaliação do impacto ambiental, como um instrumento nacional, deve ser empreendida para atividades propostas que tenham probabilidade de causar um impacto adverso significativo no ambiente e sujeitas a uma decisão da autoridade nacional competente".

Mesmo em locais onde a AIA não está prevista na legislação ou em procedimentos administrativos, o instrumento tem sido aplicado por força de exigências de organismos internacionais. É o caso do Banco Mundial que, desde 1989, adota uma política de avaliação ambiental com o propósito de "assegurar que as opções de desenvolvimento consideradas são ambientalmente corretas e sustentáveis e que quaisquer conseqüências ambientais são reconhecidas no início e consideradas na concepção do projeto” (BEANLANDS, 1993). Esta política dos organismos internacionais foi responsável pela realização de numerosos estudos ambientais em países em desenvolvimento, induzindo-os à adoção dos procedimentos de AIA em seus sistemas de proteção do meio ambiente.

A avaliação de impacto ambiental, como instrumento de decisão na aprovação de projetos, atividades e mesmo políticas, leis, planos e programas, encontra-se hoje disseminada amplamente em todo o mundo, seja inserida no sistema de proteção do meio ambiente de muitos países (mais de uma centena), na forma de leis ou procedimentos administrativos, seja pela atuação de organismos internacionais, dos quais depende a maioria dos grandes projetos de infra-estrutura dos países em desenvolvimento. Considerados os procedimentos de âmbito estadual (ou provincial), o número total de jurisdições em todo o mundo que adotam o processo de AIA é estimado em cerca de 200. (SADLER, 1996)

\subsection{A natureza da AIA e seus papéis}

Discutindo a diversidade dos conceitos de avaliação de impacto ambiental encontrados em livros-texto e documentos legais, comparados aos expressos por profissionais interessados no tema, SÁNCHEZ (1998) apresenta uma coleção de 
definições (Quadro 1.1) nas quais se destacam como atributos essenciais da AIA seu caráter prévio, seu vínculo com o processo decisório e a necessidade de envolvimento público no processo.

- MUNN, 1979: Atividade que visa identificar, prever, interpretar e comunicar informações sobre as conseqüências de uma determinada ação sobre a saúde e o bem-estar humanos. (Ação é definida como qualquer projeto de engenharia, proposição legislativa, política, programa ou procedimento operacional).

- JAIN et al., 1977: Um estudo das mudanças prováveis nas várias características socioeconômicas e biofísicas do meio ambiente que podem resultar de uma ação proposta ou iminente.

- CLARK; HERINGTON, 1988: Uma abordagem estruturada e um conjunto formal de procedimentos para assegurar que os fatores ambientais sejam levados em conta em todos os níveis do processo decisório.

- GLASSON et al., 1994: Um processo sistemático que examina antecipadamente as conseqüências ambientais de ações humanas.

- IAIA, 1996: Processo de identificar, prever, avaliar e mitigar os efeitos relevantes de ordem biofísica, social ou outros de projetos ou atividades antes que decisões importantes sejam tomadas.

- MOREIRA, 1992: Instrumento de política ambiental, formado por um conjunto de procedimentos capaz de assegurar, desde o início do processo, que se faça um exame sistemático dos impactos ambientais de uma ação proposta (projeto, programa, plano ou política) e de suas alternativas, e que os resultados sejam apresentados de forma adequada ao público e aos responsáveis pela tomada de decisão, e por eles sejam considerados. Além disso, os procedimentos devem garantir a adoção das medidas de proteção ao meio ambiente determinadas, no caso de decisão sobre implantação do projeto.

\section{Quadro 1.1: Definições de avaliação de impacto ambiental Fonte: SÁNCHEZ, 1998}

A avaliação de impacto ambiental não é conduzida apenas para incrementar os conhecimentos acerca das relações entre determinadas atividades humanas e o meio ambiente natural ou construído. A AIA objetiva, fundamentalmente, subsidiar decisões. Embora seja este o papel mais tradicionalmente atribuído à AIA, não é o único. Respondendo à questão Para que serve a AIA?, SÁNCHEZ (1995a) identifica quatro papéis complementares que este instrumento pode desempenhar: (i) ajuda à decisão, (ii) ajuda à concepção de projetos, (iii) instrumento de gestão ambiental e (iv) instrumento de negociação social.

No papel de ajuda à decisão, a AIA pode estar atrelada ao processo de licenciamento de atividades ou ter emprego mais amplo, atingindo até mesmo ações não passíveis de licenciamento, como por exemplo leis, planos e programas. A tomada de decisão pode dar-se no âmbito de órgãos de governo, ao licenciar ou autorizar uma 
atividade; de organismos de financiamento, ao conceder empréstimos ou fundos para a execução de projetos e obras; ou de empresas, na escolha da melhor alternativa para o direcionamento de suas atividades.

A AIA pode e deve ser capaz de auxiliar na concepção de projetos, influindo na escolha do local para a instalação do empreendimento, do processo tecnológico a ser adotado e em numerosos outros detalhes. Este papel somente pode ser adequadamente desempenhado se os estudos ambientais forem conduzidos desde o início e de maneira integrada com os estudos técnicos e econômicos. Em fases posteriores, quando o projeto já está formulado, informações oriundas dos estudos ambientais podem resultar em alterações, seja por interferência dos órgãos ambientais, seja por decisão do próprio proponente.

Como instrumento de gestão ambiental, a aplicação dos procedimentos de AIA produz os elementos fundamentais para a concepção de um sistema de gestão ambiental que, uma vez implantado, servirá para garantir a implementação das medidas de proteção ao meio ambiente estabelecidas no processo e avaliar o acerto das previsões, tanto dos impactos ambientais, como da eficiência das medidas propostas para sua atenuação.

Finalmente, o papel da AIA como instrumento de negociação social advém dos mecanismos de participação pública que a integram. A participação do público, que pode atingir diferentes níveis de envolvimento, dependendo de legislações, políticas de governo e mesmo de políticas empresariais, é capaz de revelar a percepção que ele tem do projeto e de seus impactos ambientais, que nem sempre coincide com a dos especialistas, permitindo administrar, antecipadamente e com maior eficácia, futuros conflitos com a sociedade.

\subsection{Etapas de realização da AIA}

Com diferentes formulações nas muitas jurisdições onde é empregada, a AIA engloba sempre um conjunto articulado de atividades e procedimentos ao qual se denomina processo de avaliação de impacto ambiental. De acordo com SADLER (1996), este processo divide-se em três grandes estágios: (i) avaliação preliminar, que corresponde à classificação da atividade proposta com relação ao tipo e nível de avaliação requerida; (ii) avaliação detalhada, que engloba uma abordagem científica multidisciplinar para a coleta e análise de informações e opiniões, a elaboração de um 
relatório de impacto ambiental e sua análise, que deve sempre considerar a participação do público; e (iii) acompanhamento da decisão, que pode incluir modificações na proposta original ou imposição de condições a ser implementadas. SADLER (op cit.) considera que, com raras exceções, este estágio do processo apresenta-se mais frágil do que os precedentes.

A literatura é rica em modelos que buscam representar o processo de AIA em suas muitas versões. SÁNCHEZ (1998) elaborou o diagrama da Figura 1.1 que contém os pontos comuns e mais freqüentemente presentes neste processo; "não se trata do processo brasileiro, paulista ou americano, mas de um processo universal”. Nem todas as etapas representadas na figura estão presentes em todas as jurisdições e o modo como são desenvolvidas, assim como sua importância no processo, varia consideravelmente. As etapas podem ser agrupadas em três grandes blocos que correspondem a: (i) etapas iniciais, quando se procede à avaliação inicial, definindo-se o tipo de estudo ambiental a que deve ser submetida a proposta; (ii) análise detalhada, que engloba desde a execução do estudo de impacto ambiental até sua análise e tomada de decisão pelo órgão competente, com a necessária participação pública; e (iii) etapa pós-aprovação, que inclui o monitoramento dos impactos ambientais e medidas mitigadoras, assim como programas de gestão ambiental e auditoria. 


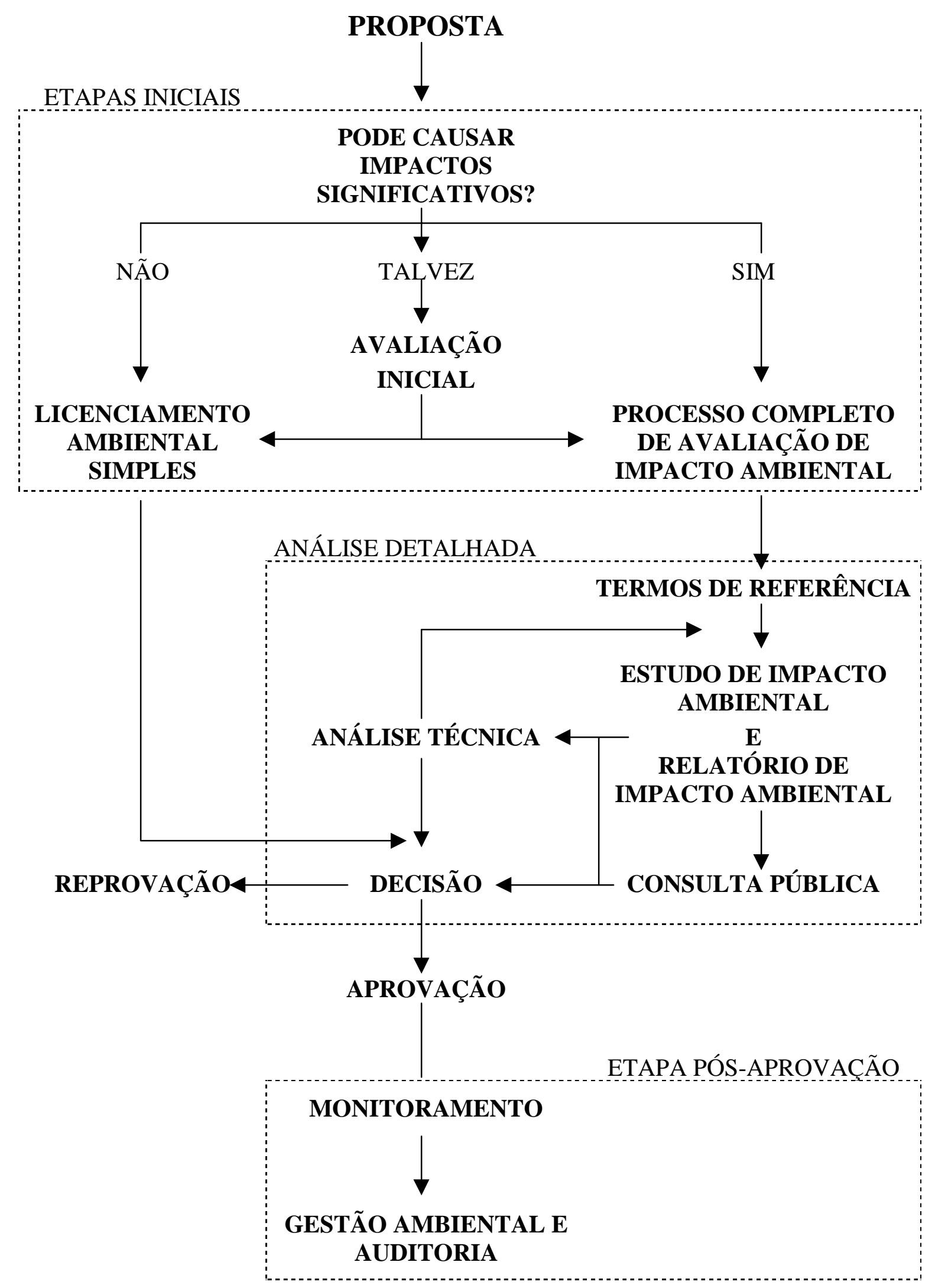

Figura 1.1: Processo de avaliação de impacto ambiental Fonte: SÁNCHEZ, 1998 


\subsubsection{Etapas iniciais}

Uma rápida observação da etapa central do processo de AIA — análise detalhada - , e da multiplicidade de atividades que a integram, permite vislumbrar a necessidade e importância das etapas iniciais. Com efeito, o processo de AIA é complexo e moroso, tendo sido concebido para ser aplicado em ações potencialmente causadoras de significativa degradação ambiental. Determinar o que é significativo, no entanto, não é tarefa fácil, uma vez que envolve grande dose de subjetividade associada à percepção e escala de valores de cada indivíduo ou grupo social.

Para WOOD (1995), é evidente que todos os sistemas de AIA devem contemplar, de alguma forma, a triagen 1 das ações a ser submetidas ao processo completo. Caso contrário, um grande número de ações poderiam ser avaliadas desnecessariamente ou ações causadoras de impactos ambientais adversos significativos poderiam deixar de ser avaliadas.

A etapa de triagem tem, portanto, as seguintes funções: definir se é necessário proceder-se à avaliação ambiental sistemática de uma ação e, em caso positivo, determinar o alcance e a profundidade dos estudos necessários (SÁNCHEZ, 1999). A esta tarefa corresponde responder à questão "a ação pode causar impactos significativos?". No caso de respostas taxativas, ou seja, "sim" e "não", o resultado pode ser o encaminhamento da ação ao processo completo de AIA ou a um licenciamento ambiental simples. Em muitos casos, no entanto, existem incertezas sobre a natureza, magnitude e importância dos impactos que a ação pode vir a causar, sendo necessária uma avaliação inicial.

Vários mecanismos de triagem têm sido aplicados e desenvolvidos nos numerosos sistemas de AIA disseminados em todo o mundo. SADLER (1996) relaciona quatro grupos principais:

(a) lista de atividades com efeitos ambientais significativos;

(b) mecanismos de triagem caso a caso;

(c) critérios gerais; $\mathrm{e}$

(d) lista de recursos ou áreas de importância especial ou áreas sensíveis.

Nas listas de atividades, estas podem ou não ser especificadas com base em valores limite para parâmetros de projeto como volume de produção, matérias-primas consumidas, demanda energética, mão-de-obra ocupada, custo de implantação, área

\footnotetext{
${ }^{1}$ Em língua inglesa esta etapa é denominada screening.
} 
ocupada etc. De acordo com TOMLINSON (1985), as listas — positivas, negativas ou intermediárias - podem ser elaboradas a partir da análise de projetos implantados. Enquanto os projetos que causaram impactos ambientais significativos passam a integrar listas positivas, projetos que raramente tiveram consequiências ambientais adversas usualmente integram listas negativas, ou seja, de projetos que não requerem avaliação detalhada. Existe, ainda, a categoria de projetos intermediários, que são aqueles para os quais há incerteza sobre a significância dos impactos prováveis. Nestes casos, outros métodos de triagem devem ser empregados.

Os mecanismos de triagem caso a caso, nos quais se aplica o poder discricionário da autoridade ambiental, apoiam-se em critérios de significância como os adotados pelo US Council on Environmental Quality (CEQ). São dez critérios reproduzidos no Quadro 1.2.

1. O impacto é benéfico ou adverso?

2. A ação afeta a segurança ou a saúde pública?

3. A ação situa-se em área geográfica especial?

4. Há controvérsia a respeito dos efeitos potenciais?

5. A ação proposta envolve riscos muito incertos, especiais ou desconhecidos?

6. A ação estabelece precedente para ações futuras com efeitos significativos ou representa uma decisão sujeita a considerações futuras?

7. A ação está associada a outras atividades cujos impactos são individualmente insignificantes, mas cumulativamente significativos?

8. Em que nível a ação pode afetar sítios protegidos?

9. Em que nível a ação pode afetar adversamente espécies ou hábitats ameaçados?

10. A ação contraria a legislação ambiental?

Quadro 1.2: Critérios de significância do US Council on Environmental Quality Fonte: ESTADOS UNIDOS (2001), adaptado.

As listas de recursos ou áreas de importância especial ou áreas sensíveis são estabelecidas partindo-se da premissa de que as conseqüências ambientais de um projeto decorrem em grande medida do meio receptor. TOMLINSON (1985) propõe duas maneiras, distintas e complementares, para a identificação de áreas sensíveis. A primeira abordagem consiste na determinação da capacidade de suporte da área em relação às interferências ou distúrbios. $\mathrm{O}$ autor reconhece que esta abordagem requer grande quantidade de informações relativas ao meio, estando sujeita a erros e controvérsias. Outra é a determinação da importância dos componentes individuais da área, considerando suas características e seu valor objetivo e subjetivo. Uma área pode 
ser considerada sensível pela importância de seu uso (recreativo, refúgio de fauna silvestre) ou por sua raridade (não existem áreas semelhantes na região).

Os mecanismos de triagem baseados em listas de projetos ou de áreas sensíveis são considerados mais objetivos e de fácil aplicação quando confrontados com os demais, porém, a dificuldade de confecção das listas obriga a adoção de outras abordagens. Na prática, os vários sistemas de AIA adotam procedimentos que combinam listas de projetos e áreas sensíveis, limites de projeto e análises caso a caso apoiadas em critérios gerais e poder discricionário da autoridade ambiental. Do ponto de vista da eficácia desta etapa, o mais importante é que os procedimentos e critérios em que se baseia a decisão de encaminhar ou não uma ação ou projeto para análise detalhada sejam transparentes e defensáveis. Nesse sentido, a existência de canais para participação do público nesta etapa pode evitar problemas futuros, principalmente no âmbito do Poder Judiciário.

\subsubsection{Análise detalhada}

Seja qual for o mecanismo adotado, a etapa de triagem remeterá as propostas de projetos ou ações com potencial para causar impacto ambiental para (i) um procedimento de licenciamento simples, (ii) um processo completo de avaliação de impacto ambiental ou, ainda, (iii) uma reprovação direta. Esta última situação (não representada na Figura 1.1) pode ocorrer, por exemplo, quando as etapas iniciais revelarem a existência de impedimentos legais incontornáveis para a instalação do projeto ou ação proposta. O licenciamento simples, é bom lembrar, inclui mecanismos de controle ambiental em princípio adequados para projetos e ações cujos impactos são insignificantes ou podem ser atenuados com a implementação de medidas de eficácia comprovada.

\section{Termos de referência}

Uma vez definido que uma ação ou projeto deve ser submetida ao processo completo de avaliação de impacto ambiental, o passo seguinte é o estabelecimento do termo de referência que irá nortear os estudos ambientais. Denomina-se termo de referência ao documento no qual se registram as conclusões e decisões emanadas da atividade de identificação das principais questões que devem ser tratadas no estudo de impacto ambiental, assim como dos estudos necessários para o adequado tratamento destas questões. 
Este processo de identificação das questões principa足 não faz parte dos requisitos originais do Nepa, mas foi adicionado posteriormente, em 1978, em resposta à natureza enciclopédica de muitos estudos de impacto ambiental (WOOD, 1995). O processo consiste, em linhas gerais, em preparar longas listas de impactos ambientais prováveis associados à ação proposta para em seguida depurá-las, focalizando a atenção nos impactos significativos. Assim como na etapa de triagem, a determinação do que é significativo é a questão-chave . Em última análise, esta decisão terá de ser tomada por indivíduos com nível apropriado de conhecimento e experiência que definirão que efeitos significativos podem ocorrer, que impactos serão causados no meio ambiente e que estudos serão necessários para avaliá-los. Os trabalhos desenvolvidos na etapa de triagem, particularmente a avaliação inicial, fornecem muitos subsídios para esta etapa.

Vários autores (BEANLANDS, 1988; SADLER, 1996; WOOD, 1995) sustentam que o processo de identificação das questões principais deve contemplar mecanismos de participação pública. A opinião do público acerca da importância dos impactos ambientais nem sempre coincide com a dos especialistas e sua participação no processo pode enriquecê-lo, além de constituir-se em salvaguarda contra futuros questionamentos das decisões tomadas. Esta participação pode, no entanto, surtir efeitos opostos aos desejados, induzindo as autoridades ambientais a incluir questões irrelevantes no termo de referência.

A condução inadequada ou a não-realização da atividade de identificação das questões principais e definição do termo de referência pode resultar em estudos de impacto ambiental excessivamente volumosos, com abrangência desnecessária, que, mesmo assemelhando-se a catálogos ou enciclopédias, podem não identificar aspectos e impactos ambientais significativos, que muitas vezes serão identificados tardiamente na etapa de análise, demandando revisões onerosas.

\section{Estudo e relatório de impacto ambiental}

O passo seguinte na análise detalhada de uma ação ou projeto com potencial de causar impactos ambientais significativos é a realização do estudo de impacto ambiental $\left(\mathrm{EIA}^{3}\right.$ ) e preparação do relatório de impacto ambiental (Rima ${ }^{4}$ ). De acordo com

\footnotetext{
${ }^{2}$ Em língua inglesa, esta etapa é denominada scoping.

${ }^{3}$ Em língua inglesa, utiliza-se a sigla EIS -Environmental impact statement, entre outras.

${ }^{4}$ Em língua inglesa, a designação mais comum para o relatório é Summary EIS.
} 
SÁNCHEZ (1995a), "a elaboração do EIA é a etapa que possui maior conteúdo técnico-científico do processo de AIA e, normalmente, a que consome mais tempo e recursos; no entanto, ela é apenas um dos elos da cadeia”. Os resultados deste estudo, apresentados em relatórios técnicos em geral extensos e complexos, constituem a principal base para a análise da viabilidade ambiental da ação proposta e tomada de decisão. Devido à complexidade dos relatórios do estudo de impacto ambiental, é usual a elaboração de um outro relatório, em linguagem acessível ao público em geral. No Brasil este relatório é conhecido pela sigla Rima.

Um dos requisitos da AIA, comum em várias jurisdições, é a análise de alternativas, que podem referir-se tanto à tecnologia adotada no projeto, como à sua localização. A alternativa de não-realização da obra ou projeto também é explicitamente mencionada em vários sistemas e corresponde basicamente às justificativas do projeto. Além da comparação das conseqüências ambientais das alternativas principais, efetuada em geral previamente ao aprofundamento do estudo de uma delas, o estudo de impacto ambiental, quando conduzido desde as primeiras etapas de concepção e desenvolvimento de um projeto, permite a comparação de numerosas alternativas de concepção de partes do projeto, como os sistemas de tratamento de efluentes, disposição de resíduos etc.

A realização do estudo de impacto ambiental constitui-se em uma sequiência articulada de atividades que SÁNCHEZ (1999) agrupa em seis etapas básicas:

1. Identificação preliminar dos impactos;

2. Identificação das questões principais;

3. Estudos de base;

4. Previsão de impactos;

5. Avaliação de impactos;

6. Plano de gerenciamento ambiental.

Dependendo do sistema de AIA considerado, as duas primeiras etapas já terão sido realizadas, para definição do termo de referência. De todo modo, são essenciais para garantir ao estudo uma abordagem dirigida, evitando-se o desperdício de tempo e recursos com estudos e trabalhos de campo desnecessários.

ORTOLANO (1997) discute vários métodos utilizados para a identificação preliminar dos impactos, destacando as listas de verificação (checklists), as matrizes de impacto, os fluxogramas que concatenam ações e impactos diretos ou indiretos, as informações disponíveis na literatura a respeito de impactos causados no passado por projetos similares e os aplicativos do tipo sistema especialista. A identificação das 
questões principais envolve a determinação da importância dos impactos que, em nível mais aprofundado, volta a ser discutida na quinta etapa, avaliação dos impactos.

Os estudos de base, que fundamentam o diagnóstico ambiental da área, correspondem à coleta de informações, primárias e secundárias, sobre o meio físico, biótico e antrópico da área. O diagnóstico ambiental descreve as condições existentes em um determinado meio, num dado instante, anterior ao empreendimento, de modo a permitir sua comparação com as condições posteriores ao empreendimento, seja por métodos de previsão dos impactos, no decorrer da realização do EIA, seja após a implantação do projeto, nas atividades de monitoramento. O tipo e quantidade de informações a ser coletadas, assim como a extensão da área de estudo deve ser a necessária e suficiente para que, nas etapas subseqüentes do estudo de impacto ambiental, possam ser estabelecidas as relações entre o projeto proposto e o meio no qual se irá inserir. BEANLANDS (1988) enfatiza a relação entre os estudos de base, que fornecem o registro da situação do meio antes do projeto, e o monitoramento, que fornece as medidas pós-projeto, revelando as alterações ocorridas e permitindo sua avaliação.

Enquanto a identificação de impactos busca enumerar as diversas conseqüências de um projeto ou ação sobre o meio, a previsão de impactos procura determinar sua magnitude ou intensidade, embasando a etapa seguinte dos estudos, a avaliação de impactos. A previsão de impactos requer a aplicação de métodos e técnicas científicas hábeis para antecipar alterações futuras no valor das várias medidas de qualidade ambiental. De acordo com ORTOLANO (1997), a maioria das previsões de impacto apoia-se em opiniões de especialistas, que podem em muitos casos atuar em grupo, com o emprego de técnicas, como por exemplo o método de Delphi, que utiliza questionários para coletar as opiniões dos vários especialistas. São também empregados na previsão de impactos métodos baseados em experimentos, modelos físicos e modelos matemáticos.

A avaliação de impacto é a etapa na qual se atribuem valor, importância e significado aos impactos identificados e previstos. É uma tarefa carregada de subjetividade, uma vez que depende de critérios de importância que, por sua vez, dependem da escala de valores que norteia o julgamento de cada indivíduo ou grupo social. O resultado da avaliação de impacto reflete-se diretamente nas decisões de aprovação ou reprovação de um projeto, assim como na definição dos condicionantes 
para sua aceitação. Por esta razão, algumas jurisdições procuram definir formalmente os critérios a ser empregados para a determinação da significância dos impactos. É o caso do sistema de AIA canadense que considera a magnitude, a extensão geográfica, a duração e freqüência, a irreversibilidade e o contexto ecológico como critérios de significância (SADLER, 1996). Este autor enumera, ainda, com vistas às boas práticas ambientais, condições nas quais os impactos podem ser considerados significativos:

- são extensivos no tempo e no espaço;

- são intensivos em concentração com relação à capacidade de assimilação;

- excedem padrões ambientais ou outros limites;

- não são compatíveis com políticas ambientais, planos de uso do solo, estratégias de sustentabilidade;

- afetam, de maneira adversa e severa, áreas ecologicamente sensíveis;

- afetam, de maneira adversa e severa, o patrimônio arqueológico, outros usos do solo, usos e costumes da comunidade, tradições e valores de povos indígenas.

É interessante notar que os esforços envidados para retirar a carga de subjetividade que acompanha o termo significativo muitas vezes terminam por substituílo por outros qualificativos como intensivo, extensivo, severo, tão sujeitos a controvérsias quanto o original. Esta é uma das razões que fortalecem a necessidade de participação pública no processo de AIA.

Finalmente, a última etapa do estudo de impacto ambiental é a proposição de um plano de gerenciamento ambiental do empreendimento. Fazem parte deste plano as medidas mitigadoras, capazes de atenuar ou eliminar os impactos negativos; as medidas compensatórias, propostas quando os impactos não podem ser evitados e não são passíveis de atenuação; e o plano de monitoramento. SÁNCHEZ (1999) lembra, ainda, a necessidade de medidas de valorização dos impactos positivos, propostas para que estes se concretizem em benefício da região onde o empreendimento será implantado, ou seja, da comunidade que irá arcar com os impactos negativos. O plano de monitoramento deve ser capaz de verificar o acerto das previsões, comparando os impactos ocorridos com os previstos, e a eficiência das medidas mitigadoras, além de contemplar mecanismos de intervenção quando os impactos reais superarem certos limites.

Há, evidentemente, interação entre as várias etapas, notadamente entre a avaliação de impacto e a proposição de medidas mitigadoras, já que a viabilidade ambiental do empreendimento é decidida com base na avaliação dos impactos 
ambientais negativos residuais, ou seja, após a aplicação das medidas mitigadoras propostas. Por outro lado, o dimensionamento das medidas mitigadoras, a proposição das medidas compensatórias e a concepção do plano de monitoramento decorrem da importância que foi atribuída aos impactos na fase precedente.

\section{Consulta pública}

A necessidade de avaliar a significância dos impactos ambientais está presente em diversas etapas do processo de AIA - triagem, seleção das questões principais, avaliação de impacto - e constitui um dos seus grandes desafios, uma vez que carrega forte dose de subjetividade. De fato, cada indivíduo ou grupo social tem sua própria escala de valores, que se reflete em sua percepção dos impactos ambientais decorrentes de um projeto ou ação. Envolver o público no processo decisório foi uma forma encontrada para contornar o problema. A transparência e a participação pública são, portanto, marcas características do processo de AIA, podendo ser consideradas como o grande diferencial entre este e o licenciamento simples.

Dentre as várias formas de envolvimento, destacam-se a consulta e a participação que, mesmo sendo freqüentemente empregadas como sinônimos, guardam diferenças importantes relativas ao nível de controle que o público detém sobre o processo. Na consulta, o objetivo maior é ouvir o público; na participação, o pressuposto é de que o público tenha uma fatia do poder de decisão. A Figura 1.2 Participação pública nas decisões —, adaptada de PARENTEAU (1988), destaca o crescimento da participação do público nas decisões, desde o nível zero até o controle total. A transição entre as cinco formas de participação relacionadas - informação, persuasão, consulta, cooperação e controle - corresponde a uma crescente transferência do poder de decisão da organização (empresa, governo) para o público. Cada uma destas formas de participação requer o emprego de uma ou mais técnicas de envolvimento do público. 


\begin{tabular}{|c|c|c|c|c|}
\hline \multicolumn{5}{|c|}{ PODER DECISÓRIO DA ORGANIZAÇÃO } \\
\hline Informação & Persuasão & Consulta & Cooperação & Controle \\
\hline $\begin{array}{l}\text { A decisão é } \\
\text { tomada e o } \\
\text { público é } \\
\text { informado }\end{array}$ & $\begin{array}{l}\text { A decisão é } \\
\text { tomada e um } \\
\text { esforço é feito } \\
\text { para convencer } \\
\text { o público. }\end{array}$ & $\begin{array}{l}\text { O problema é } \\
\text { apresentado, } \\
\text { opiniões são } \\
\text { coletadas, a } \\
\text { decisão é } \\
\text { tomada. }\end{array}$ & $\begin{array}{l}\text { Os limites são } \\
\text { decididos, a } \\
\text { decisão é } \\
\text { dividida com o } \\
\text { público e } \\
\text { tomada em } \\
\text { conjunto. }\end{array}$ & $\begin{array}{l}\text { A decisão é } \\
\text { tomada pelo } \\
\text { público, que } \\
\text { assume a } \\
\text { responsabili- } \\
\text { dade pública. }\end{array}$ \\
\hline
\end{tabular}

Figura 1.2: Participação pública nas decisões

Fonte: EIDSVIK (1978 apud PARENTEAU, 1988)

ORTOLANO (1997) destaca os principais objetivos que podem ser atingidos por meio da participação pública no processo de AIA:

- aprimorar decisões com potencial de causar impactos em comunidades ou no meio ambiente;

- possibilitar aos cidadãos a oportunidade de se expressar e de ser ouvidos;

- possibilitar aos cidadãos a oportunidade de influenciar nos resultados;

- avaliar a aceitação pública de um projeto e acrescentar medidas mitigadoras;

- desarmar a oposição da comunidade ao projeto;

- legitimar o processo de decisão;

- atender requisitos legais de participação pública;

- desenvolver mecanismos de comunicação em duas vias entre o proponente do projeto e os cidadãos para identificar as preocupações e valores do público; fornecer aos cidadãos informações sobre o projeto; informar os responsáveis pela decisão sobre alternativas e impacto do projeto.

Deste modo, as várias partes interessadas no processo - proponente do projeto, autoridade ambiental, comunidade afetada, comunidade científica, organizações nãogovernamentais (ONGs) - podem valer-se dos mecanismos de participação pública, utilizando-os para seus próprios propósitos. A escolha da técnica de comunicação a ser empregada depende do objetivo, dos agentes do processo e do segmento de público que se pretende atingir.

CONNOR (1998) descreve algumas técnicas de comunicação utilizadas pelo proponente do projeto, relacionando-as com a fase do projeto e seu poder de alcance em relação ao vários segmentos do público. Estas técnicas, que incluem folhetos simples, de ampla distribuição; exposições acompanhadas por técnicos da empresa; seminários reunindo representantes do proponente, grupos de cidadãos e organizações interessadas; e relatórios técnicos sobre o projeto à disposição do público com formação profissional, 
atingem, cada uma, determinada parcela do público, desempenhando um papel específico.

No contexto do processo de AIA, a participação pública ocorre, geralmente, vinculada à etapa de análise técnica e decisão, embora algumas jurisdições busquem o envolvimento do público também em outras etapas, em especial a triagem e a preparação dos termos de referência. O mecanismo mais largamente adotado são as audiências públicas, que apresentam severas limitações, como as enumeradas por SÁNCHEZ (1999):

- favorecem um clima de confronto;

- representam um jogo de soma nula;

- dão margem à manipulação por aqueles que têm mais poder econômico ou maior capacidade de mobilização;

- ocorrem muito tarde no processo de AIA, quando muitas decisões importantes sobre o projeto já foram tomadas;

- a maior parte do público dispõe de pouquíssima informação sobre o projeto e seus impactos e os processos de informação pública que deveriam precedê-la são deficientes;

- os tomadores de decisão usualmente não estão presentes;

- uso freqüente de argumentos tecno-científicos num contexto político em que a "verdade científica" não pode ser verificada; (PARENTEAU, 1988 apud SÁNCHEZ, 1999)

- uso frequiente de argumentos jurídicos tentando invalidar ou tornar não legítimas decisões tomadas anteriormente ou a serem tomadas;

A participação pública é criticada por muitos, pois torna o processo de AIA mais complexo e moroso. A contribuição do público, no entanto, mesmo não sendo obrigatória, pode ser fundamental para o aprimoramento do projeto e, às vezes, decisiva para sua aceitação, evitando-se questionamentos futuros pela via judicial ou política. DIAS; SÁNCHEZ (1999) sustentam que "o sucesso da avaliação de impactos ambientais depende mais de uma atitude aberta e flexível, com muita participação, do que da aderência a qualquer procedimento rígido para identificar e prever cientificamente os impactos. A participação pública, muitas vezes, é capaz de revelar implicações de uma ação não identificadas ou devidamente avaliadas através da aplicação de outras ferramentas de avaliação”.

\section{Análise técnica}

Esta etapa é usualmente referida na literatura internacional como technical review, e corresponde, em algumas jurisdições, ao processo por meio do qual um relatório de impacto ambiental provisório atinge sua versão final. ORTOLANO (1997) 
descreve em detalhe os procedimentos adotados nos Estados Unidos, sob a égide do Nepa. Neste contexto, a agência federal responsável pela execução do estudo e elaboração do relatório distribui uma versão preliminar deste a diversas partes interessadas no processo - CEQ, Environmental Protection Agency (EPA), outras agências federais, agências ambientais locais ou estaduais, grupos interessados, ou mesmo cidadãos. As partes interessadas emitem comentários à luz dos quais a agência proponente prepara a versão final do relatório, que é distribuída aos mesmos interlocutores.

O processo cria oportunidade e canais de comunicação para que as opiniões e críticas das partes interessadas sejam conhecidas pelo proponente e pode ser uma valiosa fonte de novas informações. As partes interessadas têm garantido, ainda, um tempo para tomar conhecimento da versão final do relatório, durante o qual não pode ter início a instalação do projeto. Quando as sugestões de alterações não são atendidas e a justificativa para este não-atendimento não satisfaz algum interessado, este pode valerse de instrumentos de pressão de natureza política ou judicial.

Em geral, na etapa de análise técnica o órgão ambiental responsável e o público têm a oportunidade de opinar sobre o estudo de impacto ambiental e sobre a ação proposta, sendo seus comentários levados em conta na tomada de decisão. O objetivo da análise é aferir a qualidade do estudo, verificando sua aderência aos termos de referência ou, na falta destes, às diretrizes gerais presentes nos regulamentos. A análise é usualmente conduzida por equipes multidisciplinares vinculadas aos órgãos ambientais responsáveis pelo processo de AIA, assessoradas por especialistas quando necessário. Dependendo dos impactos associados à proposta, outros órgãos da administração podem ser consultados a respeito de assuntos de sua alçada. É o caso dos órgãos gestores do patrimônio histórico e cultural, das florestas, dos recursos hídricos, dos recursos minerais etc.

Se em todo o processo de AIA houver uma única oportunidade para a participação do público, a ocasião, sem dúvida será durante a etapa de análise técnica, que precede à decisão final. O público deve ser informado e suas contribuições devem ser incorporadas ao documento resultante da análise que pode recomendar a aprovação ou a reprovação do estudo. Freqüentemente, antes de emitir o relatório de análise, a equipe técnica solicita informações complementares ao estudo ou sugere modificações na proposta. Esta solicitação deve ser formulada após a consulta pública, incorporando 
suas contribuições. Do mesmo modo que o relatório de impacto ambiental, as informações complementares, que muitas vezes contêm alterações substanciais no projeto ou novas informações sobre a sensibilidade do meio, devem ser acessíveis às várias partes interessadas.

WOOD (1995) considera que a grande dificuldade nesta etapa é garantir objetividade e isenção na análise. Esforços têm sido envidados para definir critérios gerais de análise, mas poucas jurisdições adotaram critérios formais para esta etapa. $\mathrm{O}$ autor considera que a existência de recomendações publicadas acerca dos procedimentos empregados na etapa de análise e acerca dos métodos utilizados nesta tarefa é valiosa não apenas para aqueles diretamente envolvidos (autoridade ambiental, consultores, público), como também para os profissionais encarregados da preparação do EIA.

\section{Decisão}

O processo de AIA encerra decisões em vários momentos e com diferentes níveis de importância. Na etapa de triagem, decide-se quais projetos ou ações devem ser submetidos à avaliação de impacto e qual o nível requerido para os estudos; na fase de definição do termo de referência, elegem-se os impactos significativos, que estudos devem ser conduzidos e em que profundidade; durante a realização do estudo de impacto ambiental, escolhem-se alternativas tecnológicas ou locacionais, definem-se medidas mitigadoras e compensatórias; na etapa de análise técnica, são feitas alterações no projeto à luz das contribuições do público e da equipe encarregada da análise; e, finalmente, nesta etapa, é tomada a decisão final, que pode ser de aprovação ou reprovação da proposta. A decisão de aprovação pode, ainda, ser condicionada ao cumprimento de exigências e a de reprovação pode não ser definitiva, apenas remetendo a proposta de volta para etapas anteriores do processo, para que sejam feitas alterações no projeto ou complementação de informações.

Os modelos decisórios são variados e dependem muito da tradição política de cada jurisdição. De acordo com SÁNCHEZ (1999), a decisão final pode caber: (i) à autoridade ambiental, (ii) à autoridade responsável pela licença do empreendimento (ministério ou secretaria afeita à área do projeto); e (iii) governo (por meio de um conselho de ministros ou do chefe de governo). A autoridade a quem compete tomar a decisão final pode assessorar-se de conselhos com participação da sociedade civil, com maior ou menor autonomia e poder de decisão. 
As decisões, em geral, dependem não somente do mérito da proposta e do balanço entre os impactos positivos e negativos, mas do contexto político no qual se inserem. Os responsáveis pela tomada de decisão, em razão dos cargos que ocupam e de suas atribuições, raramente têm condições de inteirar-se do conteúdo do EIA, seja por falta de tempo, seja por não terem formação técnica e científica que lhes possibilite a sua compreensão. Dependem, pois, de sumários de avaliação que contêm, em geral, além dos objetivos, justificativas e caracterização da ação proposta, seus principais impactos positivos e negativos, sua avaliação e as medidas mitigadoras propostas.

Analisando a adequação do processo decisório em diferentes jurisdições, WOOD (1995) adota os seguintes critérios de avaliação:

- O EIA desempenha o papel central na decisão?

- A decisão somente é tomada após a conclusão do processo de AIA?

- Na etapa de decisão final o projeto pode ser reprovado ou modificado?

- A decisão compete a outros agentes além do proponente?

- O sumário de avaliação é acessível ao público?

- A decisão, suas justificativas e condicionantes são publicadas?

- As justificativas incluem o relato de como o EIA influenciou na decisão?

- Existem diretrizes públicas sobre os fatores que são considerados nas decisões?

- A consulta e participação pública é requerida na tomada de decisão?

- Existe direito de apelação contra as decisões?

- A tomada de decisão funciona de maneira eficaz e eficiente?

O autor destaca que não se pretende que o processo de AIA seja o controlador das decisões sobre projetos ou ações potencialmente degradadoras do meio ambiente, mas que ele assegure que os aspectos ambientais sejam levados em conta na concepção dos projetos e em sua autorização.

\subsubsection{Etapa pós-decisão}

O processo de AIA é, por definição, desenvolvido antes da implementação de ações potencialmente causadoras de impactos ambientais e busca antecipar os efeitos que estas ações terão sobre o meio ambiente. Este prognóstico é caracterizado por incertezas resultantes da escassez de informações associada, principalmente, à limitação de tempo e recursos disponíveis para o estudo de impacto ambiental.

Deste modo, quando a ação é de fato implementada, podem ocorrer impactos inesperados ou de magnitude diferente da prevista; as medidas mitigadoras programadas podem não ser tão eficientes quanto se esperava; e o próprio projeto pode sofrer alterações que resultem em nova relação com o meio. Pode ocorrer, ainda, que o 
proponente não implemente as medidas mitigadoras definidas na aprovação do projeto. Enfim, sem alguma forma de acompanhamento, o processo de AIA pode equiparar-se a um mero expediente para a obtenção da licença, em vez de se constituir em um exercício de gerenciamento ambiental capaz de trazer benefícios ambientais reais. Para enfrentar essas situações, o processo de AIA prevê a etapa pós-aprovação.

Na verdade, são vários os termos empregados para designar esta etapa; análise pós-decisão (EPA), programa de acompanhamento (Canadá), monitoramento e auditoria ambiental (Austrália ocidental, Hong Kong) e gerenciamento ambiental e avaliação pósprojeto são alguns exemplos (AU; SANVICENS, 1996). Acompanhamento da AIA é um termo genérico que cobre um leque amplo de atividades, desde a simples inspeção e fiscalização local até processos sistemáticos e documentados de monitoramento e auditoria. Trata-se de um conjunto de atividades ou estudos sistemáticos, desenvolvidos durante e após a fase de implementação do projeto, depois de tomada a decisão de prosseguir.

WOOD (1995) distingue dois tipos básicos de monitoramento: (i) o monitoramento da implementação e (ii) o monitoramento dos impactos.

O monitoramento da implementação objetiva verificar se a ação ou projeto foi implementada de acordo com os termos da aprovação, se as medidas mitigadoras correspondem às requeridas e se as condições impostas para a aprovação do projeto foram alcançadas. Esta verificação pode envolver inspeções, medições com uso de equipamentos, coleta e análise de amostras e julgamento profissional.

O monitoramento de impactos serve a dois propósitos principais: (i) revelar impactos inesperados ou de magnitude não prevista e (ii) gerar informações úteis para a avaliação de impacto ambiental de projetos ou ações similares. Impactos de magnitude superior à prevista podem ocorrer por erro na previsão ou por ausência ou ineficácia das medidas mitigadoras propostas. Podem, ainda, decorrer de modificações no projeto aprovado.

Cada tipo de monitoramento requer um agente diferente. AU, SANVICENS (1996) identificam três agentes principais e suas respectivas atribuições na etapa de acompanhamento do processo de AIA: (i) as autoridades responsáveis pela tomada de decisão, por exemplo, encarregam-se, usualmente, de inspecionar e verificar a implementação dos termos e condições de aprovação do projeto; (ii) o proponente do projeto encarrega-se do monitoramento dos impactos reais e da formulação e 
implementação de novas medidas mitigadoras ou da modificação das propostas, acompanhando sua eficiência; e (iii) as agências de proteção ambiental encarregam-se de verificar se os padrões ambientais estão sendo respeitados, o que depende, em grande parte, da eficiência das medidas mitigadoras. Atividades de monitoramento de impactos podem ainda ser conduzidas por estudiosos, interessados em coletar dados acerca das relações entre ações e impactos.

De acordo com BISSET; TOMLINSON (1988), é parte essencial da atividade de monitoramento verificar se o impacto observado decorre realmente do projeto ou ação implementada e não de outros agentes, que podem ser naturais ou associados a outros projetos instalados nas proximidades. É uma tarefa difícil que pode ser enfrentada com o uso de pontos de referência, ou seja, analisam-se não apenas os pontos nos quais impactos são previstos, mas também pontos seguramente não afetados pela ação. Um exemplo simples é o monitoramento da qualidade da água a montante e a jusante de um empreendimento. O simples conhecimento das alterações a jusante não é suficiente para se estabelecer relações de causa e efeito entre o empreendimento e o impacto. Acompanhando-se também as alterações a montante, esta relação pode ser estabelecida.

Recomenda-se que a programação das atividades de monitoramento seja iniciada durante a realização do estudo de impacto ambiental, já que o diagnóstico ambiental da área constitui a principal referência para comparação com a situação da área afetada pelo empreendimento após sua implantação. Os estudos de impacto ambiental mais completos incluem a definição de um plano de monitoramento com localização dos pontos de amostragem, parâmetros a ser determinados, métodos de análise e periodicidade.

É de fundamental importância que as informações obtidas no monitoramento sejam utilizadas para fundamentar alterações no gerenciamento ambiental do empreendimento. A evidência de novos impactos ou de impactos mais intensos do que o previsto deve ensejar modificações no projeto e nas medidas mitigadoras.

WOOD (1995) emprega o termo auditoria de impactos para designar a comparação entre os resultados das atividades de monitoramento de implementação e de impactos e as previsões feitas e compromissos assumidos em fases anteriores do processo de AIA. Ou seja, na auditoria o propósito é verificar a conformidade ou não do empreendimento em relação às suas condições de aprovação. Pode ser conduzida pela 
autoridade ambiental ou pelo proponente, como parte de procedimentos de auditoria interna, ou ainda, por estudiosos.

Embora úteis e necessárias, as atividades de monitoramento e auditoria pósdecisão requerem recursos expressivos e, assim como nos estudos de base e nas previsões de impacto, devem ser selecionadas por sua importância. Não se trata de preconizar o monitoramento indiscriminado de todos os parâmetros ambientais, mas sim focalizar as atenções sobre os mais significativos. A fiscalização do cumprimento das condições de aprovação do projeto, no entanto, deve ser encarada como requisito mínimo em qualquer situação; outros requisitos devem ser determinados conforme a necessidade (AU, SANVICENS, op. cit.). SADLER (1996) recomenda que o plano de monitoramento e auditoria façam parte do processo de AIA e sejam incorporados aos termos e condições da aprovação.

Apesar de sua reconhecida importância, poucas jurisdições contemplam adequadamente a etapa de pós-decisão. WOOD (op. cit.) situa as atividades de monitoramento e auditoria entre as mais frágeis dentro do processo de AIA e defende seu fortalecimento ou melhor coordenação com outros programas de monitoramento ambiental.

\subsection{Outros instrumentos de avaliação ambiental}

A avaliação de impacto ambiental (AIA), amplamente difundida em todo o mundo a partir da promulgação do Nepa, revolucionou o modelo de desenvolvimento econômico nas jurisdições onde foi adotada, nele inserindo a viabilidade ambiental como requisito para a tomada de decisões. Trouxe consigo, em variados níveis de intensidade, a participação pública no processo decisório, revelando, desta maneira, às muitas partes interessadas, informações até então restritas aos setores empresariais e governamentais.

Embora os benefícios sejam inquestionáveis, a AIA aplicada a projetos tem alcance limitado quando enfrenta as conseqüências ambientais de múltiplas causas, como vários projetos, não necessariamente de mesma natureza, que acarretam impactos ambientais individualmente insignificantes, porém significativos em seu conjunto. Para enfrentar esta situação, desenvolveu-se o instrumento avaliação de impactos 
cumulativos, que integra e avalia o resultado das atividades dos vários agentes causadores de impacto em um determinado contexto.

Outro instrumento de avaliação ambiental desenvolvido para superar limitações da AIA aplicada a projetos é a avaliação ambiental estratégica (AAE), ou avaliação ambiental de políticas, planos e programas. Este instrumento nasceu da convicção, amplamente disseminada, de que a avaliação de impacto ambiental deveria ser conduzida o mais cedo possível no processo decisório.

Dentro da família de instrumentos de avaliação ambiental, na qual PARTIDÁRIO (1998) inclui ainda a avaliação de impacto social, a avaliação tecnológica e a avaliação de riscos, o destaque emprestado aos instrumentos avaliação de impactos cumulativos e avaliação ambiental estratégica decorre de sua aplicabilidade ao tema desta tese, o que será discutido em capítulos posteriores.

\subsubsection{Avaliação de impactos cumulativos}

Problemas ambientais globais de extrema importância, como o efeito estufa, provocado principalmente por emissões de $\mathrm{CO}_{2}$ e $\mathrm{CH}_{4}$, com seus desdobramentos sobre o clima do planeta; a redução da camada de ozônio, que filtra as emissões ultravioleta que chegam à terra, causada pela ação de compostos organoclorados lançados na atmosfera; ou mesmo a chuva ácida, que destrói florestas e culturas, provocada pela contribuição de $\mathrm{SO}_{2}$ de numerosas fontes industriais, são exemplos notórios da acumulação de impactos individualmente insignificantes, mas altamente significativos quando provenientes de numerosas fontes, durante longos períodos de tempo.

O US Council on Environmental Quality (CEQ) define impacto ambiental cumulativo como o "resultante da soma do impacto incremental de uma ação aos impactos de outras ações, passadas, presentes ou com razoável probabilidade de ocorrer no futuro, independentemente do agente que executa as ações" (ESTADOS UNIDOS, 1997). Transparece desta definição, assim como de várias outras encontradas na literatura, a determinação de se levar em conta ações situadas em vários horizontes de tempo, dentro de terminados limites geográficos.

Fixar limites geográficos é um dos grandes desafios da avaliação de impactos cumulativos, pois a área afetada pode transpor fronteiras, atingindo diferentes

\footnotetext{
${ }^{5}$ Em língua inglesa, utiliza-se a expressão Strategic Environmental Assessment (SEA)
} 
jurisdições, com diferentes requisitos legais e regulamentos relativos à avaliação de impacto. Além disso, se os limites forem muito amplos, a análise pode tornar-se inviável; se forem muito estreitos, impactos significativos poderão deixar de ser incluídos e os tomadores de decisão ficarão mal-informados. ERICKSON (1994) preconiza que os limites geográficos dentro dos quais a avaliação deve ser conduzida devem corresponder ao espaço requerido para descrever plenamente as interações dinâmicas potenciais entre as ações relacionadas ao projeto e o meio ambiente.

Esta não é, certamente, uma tarefa fácil, pois as interações podem ocorrer entre ações, entre ações e o meio ambiente, e entre os componentes do ecossistema. Compreender estas ligações entre a causa (ou fonte) e seu efeito constituem o foco da avaliação de impactos cumulativos. A magnitude dos impactos combinados pode ser igual à soma dos impactos individuais - efeito aditivo - ou superior a esta - efeito sinérgico (CANADA, 1997a).

Outro desafio na avaliação dos impactos cumulativos é o estabelecimento das condições ambientais de base, que constituem a referência para a comparação entre a situação do meio antes e depois da instalação da ação proposta. BUCKLEY (1998) identifica duas abordagens principais para esta questão. A primeira consiste em comparar o total de impactos previstos e ocorridos no ambiente em decorrência da ação proposta e de todas as demais já desenvolvidas na área, com a situação original, previamente à presença de qualquer empreendimento. A outra abordagem compara a situação prevista para o meio, uma vez modificado pela ação proposta combinada com as demais, com padrões e referências previamente estabelecidos. Em última análise, no entanto, a escolha das condições de base não é propriamente uma questão científica, mas de objetivos sociais (McCOLD; SAULSBURY, 1996).

Embora haja um reconhecimento disseminado acerca da necessidade e importância de se avaliar os impactos cumulativos, persistem muitas dificuldades metodológicas para a realização desta tarefa. As incertezas que caracterizam o processo de avaliação de impacto quando aplicado a projetos específicos apresentam-se ampliadas quando outras ações, incluindo as prováveis de ocorrer no futuro, são consideradas.

De acordo com CANTER (1997), a avaliação de impactos cumulativos no contexto do processo de AIA focaliza as relações entre a ação proposta e os projetos vizinhos, nas condições de base do meio; aborda os impactos da ação proposta sobre o 
meio ambiente, combinados com os das atividades próximas. $\mathrm{O}$ autor propõe a adoção de oito princípios delineados pelo CEQ para a condução da avaliação de impactos cumulativos. Estes princípios, resumidos no Quadro 1.3, são derivados da definição de impactos cumulativos do CEQ, de pesquisas e experiências conduzidas por profissionais de AIA e da análise da literatura.

1. Impactos cumulativos são causados pela combinação de ações passadas, presentes e com razoável probabilidade de ocorrer no futuro.

2. Impactos cumulativos incluem os impactos diretos e indiretos, sobre um dado recurso, ecossistema e comunidade humana, causados por todas as ações desenvolvidas, independentemente de seu agente (público ou privado).

3. Impactos cumulativos devem ser analisados sob a ótica do recurso, ecossistema ou comunidade específica afetada.

4. É impraticável analisar os impactos cumulativos de uma ação sobre o Universo; a lista de impactos ambientais deve focalizar apenas os realmente importantes.

5. Impactos cumulativos sobre um dado recurso, ecossistema ou comunidade humana raramente estão circunscritos a fronteiras políticas ou administrativas.

6. Impactos cumulativos podem resultar da acumulação de impactos similares ou da interação sinérgica de diferentes impactos.

7. Impactos cumulativos podem durar muitos anos além da vida das ações que causaram os impactos.

8. Cada recurso, ecossistema ou comunidade humana afetada tem de ser analisada quanto a sua capacidade de acomodar impactos adicionais, que se baseia em seus próprios parâmetros de tempo e espaço.

\section{Quadro 1.3: Princípios da avaliação de impactos cumulativos}

Fonte: Adaptado de CEQ (1997 apud CANTER, 1997)

A avaliação de impactos cumulativos pode ser conduzida tanto no contexto da AIA aplicada a projetos como na avaliação de políticas, planos e programas. ORTOLANO; SHEPHERD (1995) consideram, no entanto, que a avaliação

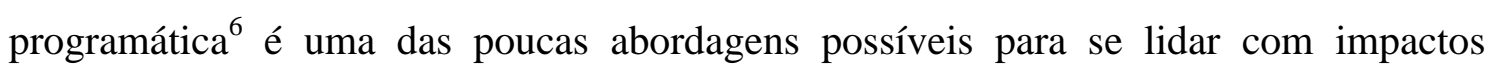
cumulativos na prática. De fato, uma das grandes dificuldades que esta tarefa envolve reside no fato de que as equipes responsáveis pelo estudo de impacto ambiental podem não ter acesso a informações sobre atividades desenvolvidas por outras empresas instaladas no local e, conseqüentemente, sobre os impactos causados. Além disso, o proponente de uma ação não tem autoridade para modificar práticas ou implementar medidas mitigadoras em outros projetos (DIAS; SÁNCHEZ, 1999).

A despeito das dificuldades que a tarefa encerra, CANTER (1997) identifica vários métodos que podem ser modificados e adaptados para analisar impactos

\footnotetext{
${ }^{6}$ Nos Estados Unidos, utiliza-se esta denominação (programmatic EIA) para designar a avaliação ambiental e políticas, planos e programas.
} 
cumulativos: questionários, entrevistas e painéis; listas de verificação; matrizes de impactos; redes ou diagramas de causa e efeito; modelagem; análises de tendência; superposição de mapas e sistemas geo-referenciados; análise da capacidade de suporte do meio; análises do ecossistema; análise de impacto econômico e análise de impacto social.

Apesar de poucos países (Canadá e Estados Unidos) exigirem a avaliação de impactos cumulativos, ERICKSON (1994) sustenta que, mesmo não sendo especificamente requerida por um dispositivo legal, a consideração dos impactos cumulativos deve ser conduzida, uma vez que é intrínseca a qualquer processo que se proponha a munir os tomadores de decisão das informações necessárias para a inclusão da questão ambiental na seleção de alternativas.

\subsubsection{Avaliação ambiental estratégica (AAE)}

O termo avaliação ambiental estratégica (AAE) é amplamente empregado para designar a aplicação da AIA à concepção de políticas, planos e programas. A principal variante desta terminologia, adotada nos Estados Unidos, é avaliação ambiental programática. A criação deste instrumento advém da crescente e generalizada convicção, por parte de todos os envolvidos na aplicação da AIA a projetos, de que a avaliação das consequiências ambientais das ações humanas deveria ser conduzida o mais cedo possível no processo.

$\mathrm{O}$ processo de planejamento ocorre em cadeia, partindo do geral para o particular. À formulação de políticas, em nível mais alto, seguem-se os planos, em segundo estágio, e os programas no final. WOOD (1995) associa a idéia de política a grandes diretrizes, entende os planos como um conjunto de objetivos coordenados e agendados para a implementação das políticas, e vê os programas como um conjunto de projetos em uma determinada área. A Figura 1.3 ilustra a hierarquia dentro do processo de planejamento, relacionando-a com o sistema de avaliação de impactos ambientais. A AAE aplica-se a ações de planejamento de diferentes naturezas em uma mesma esfera de governo (horizontal); a um mesmo tipo de ação de planejamento em diferentes esferas (vertical); ou à combinação de diferentes naturezas de ação em várias esferas (diagonal). Somente no nível de projeto, qualquer que seja a esfera de governo, aplicase a AIA. 


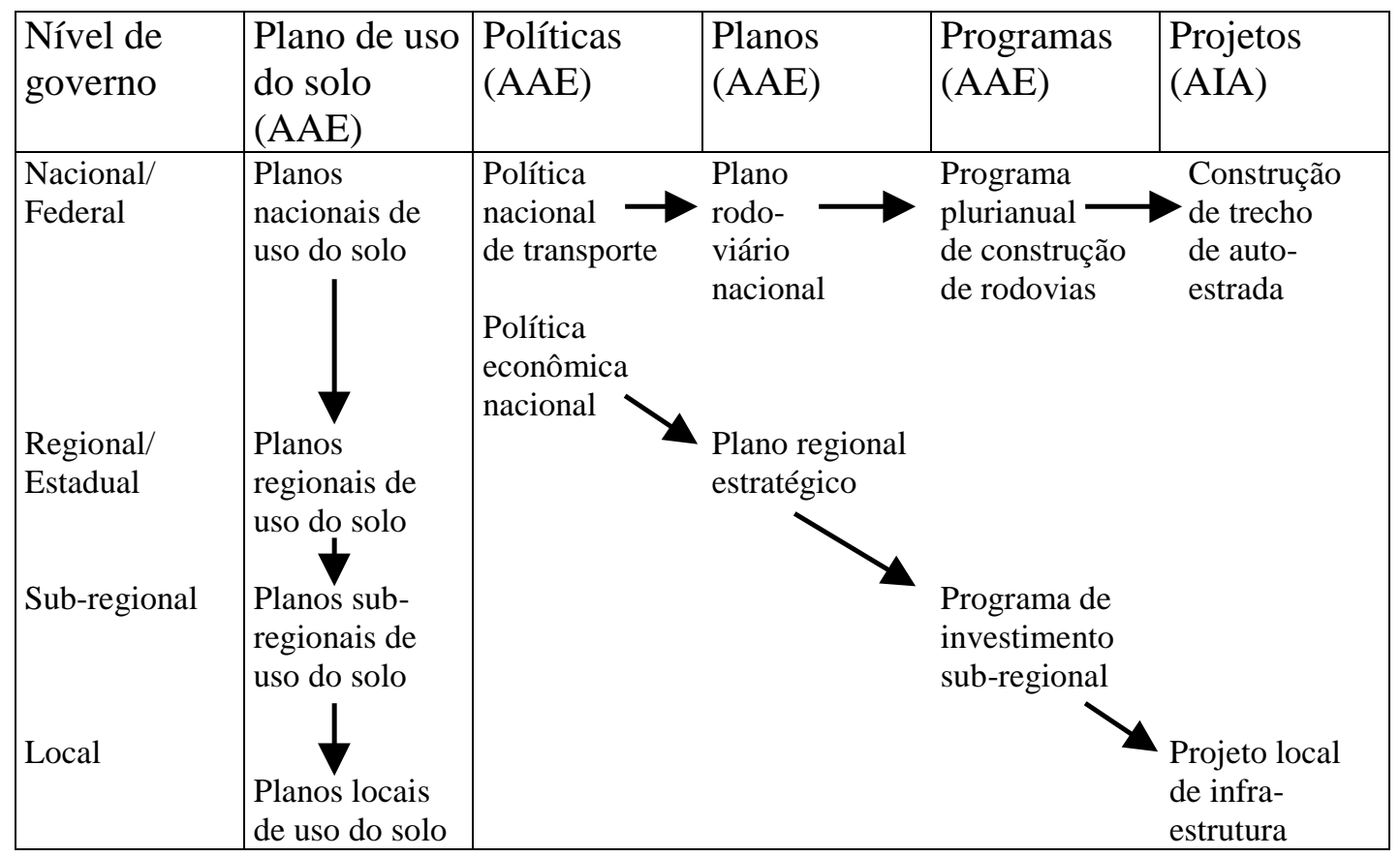

Figura 1.3: Planejamento e avaliação de impacto ambiental

Fonte: WOOD, 1995 [adaptado de LEE and WOOD (1978a); LEE and WALSH (1992)]

São exemplos de ações que podem ser submetidas à avaliação ambiental estratégica, segundo SÁNCHEZ (1999):

- planos municipais e regionais de uso do solo;

- planos de aproveitamento hidroelétrico de uma bacia hidrográfica;

- programas de desenvolvimento regional;

- políticas setoriais de recursos naturais (agrícola, florestal, pesqueira, mineral);

- outras políticas setoriais (industrial, energética, de transportes, fundiária, de habitação, de desenvolvimento turístico);

- diversas políticas econômicas (incentivos fiscais, subsídios, tributação, privatizações, redução de déficits orçamentários, ajuste estrutural);

- acordos internacionais de comércio.

SADLER; VERHEEN (1996) definem avaliação ambiental estratégica como “o processo sistemático de avaliação das conseqüiências ambientais de políticas, planos e programas propostos, com vistas a assegurar sua inclusão plena e abordagem apropriada o mais cedo possível no processo de decisão, juntamente com as considerações de ordem econômica e social”. Outras definições (THERIVEL et al., 1992) enfatizam aspectos formais, como a preparação de relatórios escritos e a responsabilização pública dos responsáveis pela tomada de decisões.

Atualmente, diversos países adotam práticas de AAE em diferentes níveis do processo de planejamento, no entanto, de 13 países enumerados por PARTIDÁRIO 
(1998), apenas os Estados Unidos, os Países Baixos e a Nova Zelândia possuem regulamentação específica para o instrumento. Nos demais, a maioria, a prática baseiase em diretivas governamentais ou mesmo em iniciativas voluntárias. A AAE é também adotada em legislações estaduais, como na Califórnia, nos Estados Unidos, que possui o sistema de AAE mais desenvolvido do mundo (WOOD, 1995), e onde a AAE já foi aplicada centenas de vezes, principalmente a planos de uso do solo.

A diversidade de conceitos, metodologias e nível de aplicação da AAE é ampla e, em análise detalhada de casos citados na literatura e estudos de caso, PARTIDÁRIO (1998) conclui que o principal aspecto comum às várias tipologias encontradas é a comunhão dos princípios de avaliação ambiental e sua aplicação a níveis superiores aos de projeto. O Quadro 1.4 resume as tipologias de AAE mais freqüentes.

- Avaliação ambiental estratégica (Strategic environmental assessment) - termo genérico que identifica o processo de avaliação de impactos ambientais de políticas, planos e programas.

- Avaliação ambiental de políticas (Policy impact assessment) - termo adotado para particularizar o processo de avaliação de políticas.

- Avaliação ambiental regional (Regional EA) - processo de avaliação das implicações ambientais e sociais regionais de propostas de desenvolvimento multissetorial numa dada área geográfica e durante um período determinado.

- Avaliação ambiental setorial (Sectorial EA) - processo de avaliação de políticas e de programas de investimento setoriais envolvendo subprojetos múltiplos; apoia também a integração de questões ambientais em planos de investimento a longo prazo.

- Sumário ambiental (Environmental overview) - utilizado no processo de formulação de programas levando à identificação de oportunidades e de impactos ambientais e sociais e incorporação de medidas de mitigação na revisão de programas.

- Avaliação ambiental programática (Programmatic environmental assessment)processo de avaliação de grupos de ação geograficamente relacionadas ou possuindo similaridades quanto à natureza tecnológica e tipologia do projeto.

\section{Quadro 1.4: Tipologias de AAE mais freqüentes}

Fonte: PARTIDÁRIO (1998), modificado.

Muitos têm sido os argumentos enumerados por diversos autores em favor da implementação da avaliação ambiental estratégica. WOOD; DEJEDDOUR (1992), por exemplo, citam os seguintes:

a) encoraja a consideração de objetivos ambientais na elaboração de políticas, planos e programas mesmo em organizações não afetas à questão ambiental;

b) facilita consultas entre autoridades e amplia o envolvimento público na avaliação de aspectos ambientais na formulação de políticas, planos e programas;

c) pode substituir avaliações de impacto ambiental de projetos, quando redundantes e quando os impactos forem adequadamente avaliados; 
d) pode deixar o exame de certos impactos para a AIA de projetos;

e) permite a formulação de padrões ou medidas mitigadoras genéricas para projetos futuros;

f) encoraja a consideração de alternativas muitas vezes ignorada ou inviável na AIA de projetos;

g) pode auxiliar na escolha de locais para projetos posteriormente submetidos à AIA.

h) permite uma análise mais eficaz dos efeitos cumulativos de projetos, tanto grandes como pequenos;

i) encoraja e facilita a consideração dos efeitos sinérgicos;

j) permite a consideração mais eficaz dos efeitos secundários das atividades;

k) facilita a consideração de impactos futuros ou de longa duração; e

1) permite a análise de impactos de políticas que podem não ser implementadas por meio de projetos.

Ao lado dos benefícios, numerosos problemas de natureza política e técnica são citados como barreiras para a implementação da AAE. WOOD (1995) considera, no entanto, que as dificuldades metodológicas parecem secundárias diante das políticas, ou seja, há enorme resistência por parte de políticos e burocratas de alto escalão em voluntariamente ceder para autoridades ambientais qualquer papel na tomada de decisões. 
Capítulo 2

AVALIAÇÃO DE IMPACTO AMBIENTAL NO BRASIL

Considera-se a promulgação da Lei da Política Nacional do Meio Ambiente, Lei $\mathrm{n}^{\mathrm{o}}$ 6938, de 31 de agosto de 1981, o principal marco na introdução da avaliação de impacto ambiental no Brasil. A edição desta lei culmina com um processo de evolução que se inicia com os dispositivos de proteção aos recursos naturais, vistos predominantemente do ponto de vista de seu valor econômico, até a gestão integrada dos recursos naturais.

\subsection{Evolução da proteção jurídica ao meio ambiente no Brasil}

A evolução da proteção jurídica ao meio ambiente no Brasil reflete e revela um processo pelo qual diferentes concepções do tratamento da questão ambiental prevaleceram nos vários momentos históricos. MONOSOWSKI (1989) distingue quatro abordagens estratégicas nas políticas ambientais brasileiras: a administração dos recursos naturais, o controle da poluição industrial, o planejamento territorial e a gestão integrada de recursos. Estas abordagens, mesmo sendo resultado de uma evolução histórica, não correspondem a períodos estanques, uma vez que muitas delas continuam a ser aplicadas, superpondo-se às posteriores.

A primeira dessas abordagens, a administração dos recursos naturais, caracteriza-se pela preocupação em racionalizar a exploração dos recursos naturais (água, flora, fauna e recursos minerais), regulamentando as atividades extrativas (pesca, mineração, exploração de madeiras) e definindo áreas de preservação. O Quadro 2.1 apresenta alguns dos principais instrumentos legais adotados. Esta legislação contém vários dispositivos considerados de preservação ambiental, como a preocupação com a poluição das águas, no Código da Pesca; sanções pela destruição de florestas, no Código Florestal; e o reconhecimento da conservação dos recursos naturais como de interesse social para efeito de desapropriação. 


\begin{tabular}{|c|c|c|}
\hline INSTRUMENTO LEGAL & LEGISLAÇÃO & MATÉRIA \\
\hline Código das Águas & 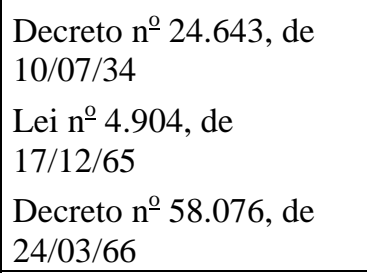 & $\begin{array}{l}\text { Define os direitos de propriedade e uso } \\
\text { dos recursos hídricos para o abasteci- } \\
\text { mento, a irrigação, a navegação, os usos } \\
\text { industriais e a produção de energia, e as } \\
\text { normas para proteção da quantidade e } \\
\text { qualidade das águas territoriais. }\end{array}$ \\
\hline Código Florestal & $\begin{array}{l}\text { Decreto } n^{\circ} 23.793, \text { de } \\
\text { 23/01/34, substituído por } \\
\text { Lei n }{ }^{\mathrm{o}} 4.771, \text { de } 15 / 09 / 65 \\
\text { Decreto } n^{\mathrm{o}} 289, \text { de } \\
\text { 28/02/67 }\end{array}$ & $\begin{array}{l}\text { Caracteriza as florestas e a vegetação } \\
\text { como bens de interesse comum, subme- } \\
\text { tidos, portanto, a limitações quanto aos } \\
\text { direitos de propriedade, estabelecendo } \\
\text { também os critérios para a delimitação } \\
\text { das áreas de preservação permanente de } \\
\text { vegetação, a criação de parques e } \\
\text { reservas biológicas, a exploração de } \\
\text { florestas e o desmatamento. }\end{array}$ \\
\hline Código de Mineração & $\begin{array}{l}\text { Decreto } \mathrm{n}^{\mathrm{o}} 1.985, \text { de } \\
\text { 29/01/40 substituído por } \\
\text { Decreto } \mathrm{n}^{\mathrm{o}} 227, \text { de } \\
\text { 28/02/67. }\end{array}$ & $\begin{array}{l}\text { Define os princípios para a prospecção e } \\
\text { a exploração das jazidas e, em especial, } \\
\text { dissocia o direito de propriedade das } \\
\text { terras do direito de exploração dos } \\
\text { recursos do subsolo. }\end{array}$ \\
\hline Código de Pesca & $\begin{array}{l}\text { Decreto } \mathrm{n}^{\mathrm{o}} 794, \text { de } \\
\text { 19/10/38 substituído por } \\
\text { Decreto-lei } \mathrm{n}^{\mathrm{o}} 221, \text { de } \\
\text { 28/02/67 } \\
\text { Lei Delegada } \mathrm{n}^{\mathrm{o}} 10, \text { de } \\
\text { 11/10/62, } \\
\text { modificada por } \\
\text { Decreto } \mathrm{n}^{\mathrm{o}} 73.632, \text { de } \\
13 / 02 / 74 \\
\text { Decreto } \mathrm{n}^{\mathrm{o}} 68.459, \text { de } \\
01 / 04 / 71\end{array}$ & $\begin{array}{l}\text { Declara pertencentes ao domínio } \\
\text { público todos os animais e vegetais das } \\
\text { águas territoriais brasileiras e fixa os } \\
\text { princípios e as modalidades para a pesca } \\
\text { e a exploração dos recursos biológicos } \\
\text { da água. }\end{array}$ \\
\hline Estatuto da Terra & $\begin{array}{l}\text { Lei } n^{-} 4.504, \text { de } \\
30 / 11 / 64\end{array}$ & $\begin{array}{l}\text { Determina os critérios e as modalidades } \\
\text { de desapropriação e de distribuição de } \\
\text { terras, as condições de taxação, as } \\
\text { normas para a colonização pública e } \\
\text { privada e para a implantação das infra- } \\
\text { estruturas de apoio à atividade rural. }\end{array}$ \\
\hline $\begin{array}{l}\text { Proteção do Patrimônio } \\
\text { Histórico e Artístico Nacional }\end{array}$ & $\begin{array}{l}\text { Decreto-Lei no } 25 \text {, de } \\
30 / 11 / 37\end{array}$ & $\begin{array}{l}\text { Prevê a preservação dos objetos e dos } \\
\text { imóveis (inclusive sítios naturais e } \\
\text { paisagens) de interesse público, por seu } \\
\text { valor arqueológico, etnográfico, } \\
\text { bibliográfico ou artístico. }\end{array}$ \\
\hline
\end{tabular}

\section{Quadro 2.1: Instrumentos legais de administração dos recursos naturais} Fonte: MONOSOWSKI (1989)

O controle da poluição ambiental é a marca da segunda abordagem estratégica identificada por MONOSOWSKI (op. cit.) e sua principal referência é a criação da Secretaria Especial do Meio Ambiente (Sema), em 1973 (Decreto n o 73.030, de 30/10/73), com amplas atribuições, porém escassos recursos para sua realização. O momento político é marcado pela realização, em 1972, da primeira Conferência das 
Nações Unidas sobre o Meio Ambiente, em Estocolmo, e pelo agravamento dos problemas ambientais decorrentes do rápido processo de industrialização e urbanização ocorrido no País, cujos reflexos se fizeram sentir especialmente nos grandes centros, na forma de poluição industrial, falta de saneamento e problemas no abastecimento de água.

A prioridade é dada para o controle da poluição industrial, com a adoção de normas e padrões inspirados na legislação norte-americana. $\mathrm{O}$ modelo desta fase pode ser sintetizado no tripé: um problema (a poluição industrial), um agente (a indústria) e um responsável pelo controle (o Estado). A legislação autoriza a criação de sistemas de licenciamento nos estados e municípios para a instalação e o funcionamento das atividades industriais potencialmente poluidoras. Em São Paulo, a Lei nº 997, de 31/05/76, regulamentada pelo Decreto $\mathrm{n}^{\mathrm{o}}$ 8468, de 08/09/76, introduziu o sistema de licenciamento para as fontes de poluição e definiu padrões de emissão e de qualidade ambiental relacionados aos diversos poluentes.

Esta abordagem evolui para a do planejamento territorial com a adoção do conceito de área crítica de poluição, definido pela primeira vez no II Plano Nacional de Desenvolvimento (PND), de 1974, mas aplicado na prática somente com a promulgação da Lei $\mathrm{n}^{\underline{0}}$ 6803, de $02 / 07 / \$ \Theta^{7}$. Inserem-se nesta abordagem as leis metropolitanas de zoneamento industrial e de proteção de mananciais e os planos de zoneamento de uso do solo para a proteção de bacias hidrográficas. As ações de controle nesta etapa continuam direcionadas para o agente privado, deixando de fora os grandes projetos de iniciativa governamental, com enorme potencial de causar modificações no meio ambiente.

O grande marco da atual política ambiental brasileira, que caracteriza a abordagem estratégica da gestão ambiental integrada de recursos, ocorre com a promulgação da Lei n⿳⺈ 6938, em 31/08/81, a Lei da Política Nacional do Meio Ambiente. BENJAMIN (1999) sustenta que esta lei dá início à fase holística do direito ambiental brasileiro, em que o ambiente passa a ser protegido como sistema ecológico integrado, ao invés da tutela dispersa que caracterizava o modelo fragmentário até então vigente. Dentre as importantes inovações em nível institucional que introduz, destacamse:

\footnotetext{
${ }^{7}$ A Lei n ${ }^{\text {o }}$ 6803/80 introduziu o estudo de impacto ambiental no Direito brasileiro, embora timidamente e com aplicação restrita a poucos tipos de zonas de uso estritamente industrial (MILARÉ; BENJAMIN, 1993).
} 
1. a criação do Conselho Nacional do Meio Ambiente (Conama), órgão consultivo e deliberativo, diretamente vinculado ao Presidente da República e encarregado de assessorar, estudar e propor diretrizes de políticas ambientais, assim como normas e padrões de controle ambiental; e

2. a criação do Sistema Nacional do Meio Ambiente (Sisnama), que inclui o conjunto das instituições governamentais que se ocupam da proteção e da gestão da qualidade ambiental, em nível federal, estadual e municipal, e também os órgãos da Administração Pública federal, cujas atividades afetem diretamente o meio ambiente. O Conama constitui a instância superior do Sisnama.

A promulgação da Lei da Política Nacional do Meio Ambiente dá-se em um contexto político marcado pelo regime autoritário, sob a égide da Constituição de 1967 (alterada pela Emenda Constitucional de 1969) extremamente centralizadora e sem qualquer preocupação com o meio ambiente e com os recursos naturais. GOUVÊA (1999) lembra que na época discutia-se o aparente conflito entre o desenvolvimento econômico e a proteção do meio ambiente; ainda assim, foram aprovados dispositivos extremamente inovadores e avançados, que promoviam uma sensível descentralização e buscavam "a compatibilização do desenvolvimento econômico-social com a preservação da qualidade do meio ambiente e do equilíbrio ecológico” (Lei nº 6938/81, Art. $\left.4^{\mathrm{o}}\right)$.

A Lei da Política Nacional do Meio Ambiente define, ainda, em seu Art. 9º, os instrumentos dos quais se valerá para a consecução de seus objetivos. São os instrumentos:

I- " "o estabelecimento de padrões de qualidade ambiental;

II- o zoneamento ambiental;

III- a avaliação de impactos ambientais;

IV- o licenciamento e a revisão de atividades efetiva ou potencialmente poluidoras;

$V$ - $\quad$ os incentivos à produção e instalação de equipamentos e à criação ou absorção de tecnologia, voltados para a melhoria da qualidade ambiental;

VI- a criação de espaços territoriais especialmente protegidos pelo Poder Público Federal, Estadual e Municipal, tais como áreas de proteção ambiental, de relevante interesse ecológico e reservas extrativistas;

VII- o sistema nacional de informações sobre o meio ambiente;

VIII- o Cadastro Técnico Federal de Atividades e instrumentos de defesa ambiental;

IX- $\quad$ as penalidades disciplinares ou compensatórias ao não cumprimento das medidas necessárias à preservação ou correção da degradação ambiental; 
X- $\quad$ a instituição do Relatório de Qualidade do Meio Ambiente, a ser divulgado anualmente pelo Instituto Brasileiro do Meio Ambiente e dos Recursos Naturais Renováveis - Ibama;

XI- a garantia da prestação de informações relativas ao Meio Ambiente, obrigandose o Poder Público a produzi-la, quando inexistentes; $e$

XII- o Cadastro Técnico Federal de atividades potencialmente poluidoras elou utilizadoras dos recursos ambientais".

Merece destaque, ainda, a responsabilização do Estado em relação às suas próprias iniciativas, até então não contempladas pelas ações de controle. A preocupação com o planejamento transparece na introdução dos instrumentos de zoneamento ambiental e na avaliação de impactos ambientais, que se aplica tanto aos projetos públicos como aos privados.

No campo da responsabilidade civil pelo dano ambiental, a Lei $\mathrm{n}^{\underline{0}}$ 6938/81 foi especialmente inovadora ao dispor que "é o poluidor obrigado, independentemente de existência de culpa, a indenizar ou reparar os danos causados ao meio ambiente e a terceiros, afetados por sua atividade" (Art. 14º,$\S 1^{\underline{0}}$ ). É a chamada responsabilidade civil objetiva, ou seja, não só independe de intenção, como de culpa. Basta que se prove a existência do dano e a sua autoria, ou seja, estabeleça-se a relação entre a causa e o efeito (nexo causal), para que o autor seja obrigado a indenizar. Nos termos da Lei no 7.347, de 24/07/85, a ação pública de responsabilidade civil pode ser proposta pelo Ministério Público Federal e Estadual, assim como pela União, Estados, Municípios, autarquias, empresas públicas, fundações, sociedades de economia mista ou associações constituídas há pelo menos um ano, desde que incluam entre suas finalidades a proteção ao meio ambiente.

A Constituição Federal de 1988, que tem todo um capítulo dedicado ao meio ambiente, consolida os princípios, diretrizes e instrumentos adotados pela Lei da Política Nacional do Meio Ambiente. O princípio básico está expresso no caput do Art. 225:

\footnotetext{
"Todos têm direito ao meio ambiente ecologicamente equilibrado, bem de uso comum do povo e essencial à qualidade de vida, impondo-se ao Poder Público e à coletividade o dever de defendê-lo e preservá-lo para as presentes e futuras gerações”.
} 
A Constituição de 1988 alterou profundamente a distribuição de competências entre a União, os Estados e os municípios. A União estabelece as normas gerais; os Estados fixam as normas suplementares, ou seja, podem suprir a inexistência de norma federal ou complementá-la; e os municípios, do mesmo modo, podem suplementar as normas federais e estaduais, quando for de interesse local. Tanto os Estados, quanto os municípios, no entanto, não podem deixar de atender às normas fixadas pelas instâncias superiores e, na prática, quando vários dispositivos legais são aplicáveis a uma determinada matéria, vale sempre o mais restritivo. MACHADO (1998) chama a atenção para a diferença entre a competência estadual e a municipal; enquanto os Estados não precisam provar que o assunto é de interesse estadual ou regional, os municípios só podem legislar sobre assuntos de interesse local.

BENJAMIN (1999) fecha o círculo da regulação legal do meio ambiente no Brasil com a aprovação da Lei dos Crimes contra o Meio Ambiente (Lei nº 9605, de 12 de fevereiro de 1998), na qual reconhece filiação holística idêntica à da Lei nº 6938/81. A lei não se restringe ao campo penal como o nome indica, mas trata também de sanções administrativas. Uma de suas principais inovações foi a adoção da responsabilidade penal da pessoa jurídica, não excluindo a das pessoas físicas. Deste modo, uma mesma conduta pode levar à condenação da empresa, de seus dirigentes e de outros indivíduos que tenham colaborado com a conduta criminosa.

\subsection{AIA no Brasil: legislação disciplinadora}

A primeira referência à avaliação de impacto ambiental na legislação federal brasileira consta da Lei $\mathrm{n}^{-}$6803, de 2 de julho de 1980, que dispõe sobre as diretrizes básicas para o zoneamento industrial nas áreas críticas de poluição. Esta lei estabelece que a aprovação de limites e autorizações de implantação de zonas de uso estritamente industrial destinadas a pólos petroquímicos, cloroquímicos e carboquímicos, assim como instalações nucleares, terá de ser "precedida de estudos especiais de alternativas e de avaliações de impacto" (Art. 10, $\S \S 2^{\underline{0}}$ e $3^{\underline{o}}$ ). Segundo VAN ACKER (1998), esta lei, por sua fraca aceitação e aplicação, faz parte do grupo daquelas que não têm história.

Antes disso, alguns projetos implantados nos anos 70 e 80, bancados por organismos internacionais de financiamento, foram objeto de estudo de impacto ambiental (SOUZA, 1999). É o caso das usinas hidrelétricas de Sobradinho (Bahia) e de 
Tucuruí (Pará) e do terminal porto-ferroviário Ponta da Madeira (Maranhão), projetado para escoar o minério produzido pela Companhia Vale do Rio Doce (CVRD) na Serra dos Carajás. Nesse sentido, MONOSOWSKI (1989) credita aos procedimentos do Banco Mundial para o financiamento de grandes projetos hídricos a instituição, pela Eletrobrás, desde 1974, de exigência desse tipo de estudos para a implantação de usinas hidrelétricas.

Mesmo antes da legislação federal disciplinar a matéria, alguns Estados já haviam aprovado normas prevendo a exigência de estudos de impacto ambiental para o licenciamento de obras ou atividades de grande porte ou de grande potencial de degradação do meio ambiente 8 .

Mas é na Lei da Política Nacional do Meio Ambiente que a avaliação de impacto ambiental ganha amplitude e é "erigida à categoria de instrumento da política nacional do meio ambiente, sem qualquer limitação ou condicionante, já que exigível tanto nos projetos públicos quanto particulares, industriais ou não-industriais, urbanos ou rurais, em áreas consideradas críticas de poluição ou não” (MILARÉ; BENJAMIN, 1993).

\subsubsection{AIA vinculada ao licenciamento}

É interessante ressaltar (GOUVÊA, 1999) que a Lei nº 6938/81 não vinculou a avaliação de impacto ambiental ao licenciamento, possibilitando sua realização não apenas no caso de obras ou atividades sujeitas ao licenciamento ambiental, como também a políticas, planos e programas. Este vínculo, no entanto, surge em sua regulamentação, primeiramente pelo Decreto $\mathrm{n}^{\mathrm{o}} 88.351 / 83$ (substituído pelo Decreto $\mathrm{n}^{\mathrm{o}}$ 99.274/90) e posteriormente na Resolução Conama $n^{\circ} 1$, de 23 de janeiro de 1986, que disciplinou a matéria. Na prática, estes dispositivos terminaram por restringir o instrumento de política ambiental formulado na Lei $\mathrm{n}^{\mathrm{o}}$ 6938/81, subordinando-o ao licenciamento e excluindo, desta maneira, sua aplicação a políticas, planos e programas.

O Art. 225 da Constituição Federal de 1988 ( $§ 1^{\underline{0}}$, inciso IV), que incumbe ao poder público "exigir, na forma da lei, para instalação de obra ou atividade potencialmente causadora de significativa degradação do meio ambiente, estudo prévio de impacto ambiental...", não chega a explicitar o vínculo com o licenciamento, mas

\footnotetext{
${ }^{8}$ Informação obtida em GOUVÊA, Y. M. G. A avaliação de impacto ambiental nas Américas. S. L., s. ed., 1999. [Inédito]
} 
restringe a aplicação do estudo a obras e atividades. Embora o termo atividades tenha sentido mais amplo, dificilmente será associado à idéia de políticas, planos e programas. Deste modo, na prática, a legislação brasileira dispõe do instrumento AIA, devidamente regulamentado, apenas para atividades e obras, ficando sua aplicação em níveis mais elevados de decisão dependente de novos dispositivos legais e normativos ou de iniciativas voluntárias.

O licenciamento ambiental foi instituído no Brasil, no plano federal, pela Lei da Política Nacional do Meio Ambiente e estruturado na forma de três licenças — Licença Prévia (LP), Licença de Instalação (LI) e Licença de Operação (LO) - pelo Decreto no ${ }^{\text {o }}$ 99.274/90 que a regulamentou (substituindo o Decreto $\mathrm{n}^{\mathrm{o}} 88.351 / 83$ ).

A Licença Prévia, concedida na fase preliminar do planejamento da atividade, traduz o entendimento de que o empreendimento proposto é ambientalmente viável, consideradas sua localização e concepção, desde que atendidos os condicionantes fixados no ato administrativo. A outorga da LP é o "sinal verde" para o detalhamento do projeto, incluídos os dispositivos de proteção do meio ambiente. É nesta fase do licenciamento que o Estudo de Impacto Ambiental deve ser apreciado, como condição para a expedição da LP. A Licença de Instalação autoriza o início da implantação do projeto, fixando as condições para a obtenção da Licença de Operação que permite o funcionamento regular da atividade, desde que todas as condições estabelecidas nas etapas anteriores tenham sido atendidas.

Embora a fase de obtenção da Licença Prévia seja o momento natural para a realização do EIA, posto que seu objetivo é influir no mérito da decisão administrativa, MILARÉ; BENJAMIN (1993) sustentam que o estudo pode ser exigido a qualquer tempo, desde que se possa remediar uma situação crítica ao meio ambiente. Citam como exemplo o estudo de impacto ambiental da Usina Hidrelétrica de Três Irmãos, no Estado de São Paulo, "encetado 11 anos após o início das obras...eem razão de se ter detectado impactos ambientais e sócio-econômicos de vulto, não responsavelmente equacionados pela empreendedora”. Nesse sentido, o próprio Conama, em sua Resolução $\mathrm{n}^{\mathrm{o}}$ 6/87 (Art. $12, \S 4^{-}$) previu a figura do Rima para a regularização, com obtenção de LO, de empreendimentos de grande porte, destinados à geração de energia elétrica, que tenham entrado em operação a partir de 01/02/86.

Os procedimentos para a concessão das licenças ambientais e sua interação com os procedimentos de avaliação de impacto ambiental foram objeto de resoluções do 
Conama para atividades específicas. É o caso da citada Resolução Conama n⿳ํㅡㄹ 6/87, que trata do licenciamento ambiental de obras de grande porte, especialmente aquelas destinadas à geração de energia elétrica e inclui o Relatório de Impacto Ambiental (Rima) entre os requisitos para obtenção da Licença Prévia. As Resoluções Conama ${ }^{\text {os }}$ 9 e 10, de 6 de dezembro de 1990, que disciplinam o licenciamento ambiental das atividades de extração mineral, relacionam o EIA e o Rima entre os documentos de instrução do requerimento da Licença Prévia.

\subsubsection{Ações que devem ser submetidas ao processo de AIA}

Com atribuições expressamente conferidas pelo Decreto $\mathrm{n}^{\mathrm{o}}$ 88.351/83, o Conama expediu a Resolução Conama $\mathrm{n}^{\mathrm{o}}$ 1/86, estabelecendo as definições, as responsabilidades, os critérios básicos e as diretrizes gerais para o uso e implementação da AIA. Esta resolução determinou que "dependerá de elaboração de Estudo de Impacto Ambiental e respectivo Relatório de Impacto Ambiental - Rima ......., o licenciamento de atividades modificadoras do meio ambiente” (Art. 2 $2^{\underline{0}}$ ). $\mathrm{O}$ artigo contém, ainda, uma listagem de atividades modificadoras do meio ambiente. O caráter desta listagem, exemplificativo ou taxativo, foi objeto de controvérsias que postergaram a adoção de critérios e procedimentos de triagem das ações que deveriam ser submetidas ao processo de AIA.

A tese de que a listagem era exemplificativa foi defendida pela Assessoria Jurídica da Cetesb (Parecer PJ nº 130/89) com base no Art. 225 da Constituição Federal, que exige o estudo prévio de impacto ambiental apenas para instalação de obra ou atividade potencialmente causadora de significativa degradação do meio ambiente e não para qualquer atividade que provoque alteração ou degradação ambiental. O emprego da expressão "tais como" encabeçando a lista e presente em seu corpo também reforçou a tese de listagem exemplificativa, embora seus opositores o equiparassem à idéia de "não apenas”. O Parecer PJ ñ 130/89 foi aprovado pelo Conselho Estadual do Meio Ambiente (Consema) do Estado de São Paulo, juntamente com a norma "Critérios de Exigência de EIA/Rima para Sistemas de Disposição de Resíduos Domiciliares, Industriais e de Serviços de Saúde" (GOUVÊA, 1998). Posteriormente, a mesma Assessoria Jurídica da Cetesb emitiu o Parecer PJ nº 241/89, aprofundando o exame da matéria e reiterando as conclusões do parecer anterior. 
MILARÉ; BENJAMIN (1993) propuseram, como forma de contornar as divergências relativas ao caráter da listagem de atividades constante do Art. $2^{\underline{o}}$ da Resolução Conama n⿳ $n^{0}$ 1/86, considerar que, em princípio, o administrador ficaria obrigado a exigir a elaboração de EIA para os casos listados, cabendo ao empreendedor produzir prova no sentido de que a obra ou atividade pretendida não provocaria impacto ambiental significativo, ou seja, "em vez do agente público ter que provar a 'significância' do impacto, é o empreendedor quem deve provar sua 'insignificância'”. É a chamada presunção relativa, que tem "o condão de inverter o ônus da prova”.

Em nível federal, o próprio Conama, ao editar a Resolução n⿳ำ 10/90 para disciplinar o licenciamento ambiental de extração de minerais sujeitos ao regime de licenciamento para seu aproveitamento, previu que determinados empreendimentos, por sua natureza, localização, porte e demais peculiaridades, pudessem ser dispensados de EIA/Rima.

Posteriormente, a Resolução Conama nº 237, editada em 19 de dezembro de 1997, pôs fim à polêmica ao estabelecer, em seu Art. 3º que “a licença ambiental para empreendimentos e atividades consideradas efetiva ou potencialmente causadoras de significativa degradação do meio ambiente dependerá de prévio estudo de impacto ambiental e respectivo relatório de impacto sobre o meio ambiente (EIA/Rima) ...”, facultando, entretanto, em seu Parágrafo Único, ao órgão ambiental competente, "verificando que a atividade ou empreendimento não é potencialmente causador de significativa degradação do meio ambiente”, definir os estudos ambientais necessários. A mesma resolução define (Art. 1ํㅡㄹ inciso III) estudos ambientais como "todos $e$ quaisquer estudos relativos aos aspectos ambientais relacionados à localização, instalação, operação e ampliação de uma atividade ou empreendimento, apresentados como subsídio para a análise da licença requerida”.

Além das atividades elencadas no Art. $2^{\circ}$ da Resolução Conama n⿳ำ 1/86, que podem ser dispensadas da apresentação do EIA/Rima mediante decisão motivada do órgão competente, e de outras atividades que, mesmo não constando da citada listagem, forem consideradas efetiva ou potencialmente causadoras de significativa degradação do meio ambiente, a legislação federal prevê, explicita e taxativamente, a exigência de estudo de impacto ambiental para determinadas atividades, por meio de dispositivos específicos. São exemplos destes dispositivos: 
- Decreto nº 87.561/82 — Impõe que, na Bacia Hidrográfica do Rio Paraíba do Sul, a autorização para pesquisa e concessão de lavra dependerão da apresentação de estudo de impacto ambiental... (Art. $7^{\underline{0}}$ ).

- Decreto $\mathrm{n}^{\mathrm{o}}$ 98.812/90, que regulamenta a Lei $\mathrm{n}^{\mathrm{o}}$ 7805/89 - Estabelece que “ $a$ criação ou ampliação de áreas de garimpagem fica condicionada à prévia licença do Ibama, à vista do Estudo de Impacto Ambiental - EIA e respectivo Relatório de Impacto Ambiental - Rima ...” (Art. 12, § 1ํㅜ).

- Decreto $\mathrm{n}^{\mathrm{0}}$ 750/93 - Determina que a supressão da vegetação primária ou em estágio avançado e médio de regeneração da Mata Atlântica somente poderá ser autorizada "quando necessária à execução de obras, planos, atividades ou projetos de utilidade pública ou interesse social, mediante aprovação de estudo e relatório de impacto ambiental” (Art. $1^{\circ}$, Parágrafo Único).

- Resolução Conama nº 20/86 - Permite que efluentes em condições superiores aos fixados na norma sejam lançados em corpos d'água desde que os padrões de qualidade do corpo receptor sejam resguardados, o que deve ser "demonstrado por estudo de impacto ambiental” (Art. 23, . Parágrafo Único).

- Resolução Conama n⿳ $5 / 87$ - Recomenda que seja incluída na Resolução Conama n⿳ำ 1/86 a obrigatoriedade de elaboração de Estudo de Impacto Ambiental nos casos de empreendimentos potencialmente lesivos ao Patrimônio Espeleológico Nacional. (Art. 3ㅁ)

- Resolução Conama n⿳ 23/94 - Define o EIA e o Rima como instrumentos do licenciamento ambiental de atividades relacionadas à exploração e lavra de jazidas de combustíveis líquidos e gás natural. (Art. $6^{\circ}$ )

- Portaria Ibama nº 887/90 - Impõe a “obrigatoriedade de elaboração de Estudo de Impacto Ambiental para ações ou empreendimentos de qualquer natureza, ativos ou não, temporários ou permanentes, previstos ou existentes em áreas de ocorrência de cavidades naturais subterrâneas ou de potencial espeleológico, que direta ou indiretamente possam ser lesivos a estas cavidades" (Art. $4^{-}$)

\subsubsection{Conteúdo do EIA e do Rima}

O Art. $5^{-}$da Resolução Conama n⿳o $1 / 86$ estabelece as diretrizes gerais que devem nortear a elaboração do estudo de impacto ambiental. São elas: 
I- $\quad$ "contemplar todas as alternativas tecnológicas e de localização do projeto, confrontando-as com a hipótese de não-execução do projeto;

II- identificar e avaliar sistematicamente os impactos ambientais gerados nas fases de implantação e operação da atividade;

III- definir os limites da área geográfica a ser direta ou indiretamente afetada pelos impactos, denominada área de influência do projeto, considerando, em todos os casos, a bacia hidrográfica na qual se localiza;

IV- $\quad$ considerar os planos e programas governamentais propostos e em implantação na área de influência do projeto, e sua compatibilidade."

$\mathrm{O}$ mesmo artigo, em parágrafo único, prevê que além dessas diretrizes gerais, o órgão ambiental competente poderá fixar diretrizes adicionais julgadas necessárias em face das características ambientais da área e das peculiaridades do projeto.

Com relação à primeira diretriz, trata-se, sem dúvida, de uma das características essenciais da avaliação de impacto ambiental, e somente tem sentido quando o estudo é realizado previamente à decisão de implantação do projeto. A discussão da hipótese de não-execução do projeto confunde-se com suas próprias justificativas.

Para alguns tipos de projeto, no entanto, a discussão de alternativas de localização fica prejudicada pela natureza da atividade. É o caso dos projetos de mineração, que são concebidos para o aproveitamento de jazidas minerais, não podendo ser implantados em outro local. O estudo de alternativas de localização, nesses casos, poderia ser conduzido sob a ótica do atendimento da demanda, mas implicaria o estudo de várias jazidas e a concepção de vários projetos para seu aproveitamento. Este é um procedimento inviável no caso geral, uma vez que para conhecer as características de uma jazida são necessários investimentos, muitas vezes vultosos, em pesquisa mineral.

Quanto à segunda diretriz, observa-se que o texto da norma faz referência às fases de implantação e operação da atividade, deixando de contemplar sua desativação, que pode perenizar ou agravar a degradação ambiental do meio socioambiental, ou mesmo causar novos impactos. Esta preocupação está parcialmente contemplada com a inclusão da "recuperação de áreas degradadas" entre os princípios formulados na Lei da Política Nacional do Meio Ambiente (Art. 2 ${ }^{\underline{o}}$, inciso VIII). Regulamentando a matéria, o Decreto n⿳0 97.632/89 determinou que "os empreendimentos que se destinam à exploração de recursos minerais deverão, quando da apresentação do Estudo de Impacto Ambiental - EIA e do Relatório de Impacto Ambiental - Rima, submeter à aprovação do órgão ambiental competente, plano de recuperação de área degradada”. Desta forma, embora restrito à atividade de mineração, os impactos ambientais gerados 
na fase de desativação do empreendimento também devem ser identificados e avaliados sistematicamente.

A citada Resolução, em seu Art. $6^{\circ}$, determina, ainda, as atividades técnicas que devem ser desenvolvidas, no mínimo, em um estudo de impacto ambiental:

I- diagnóstico ambiental da área de influência do projeto, considerando o meio físico, o meio biótico e o meio socioeconômico;

II- identificação, previsão da magnitude e interpretação da importância dos impactos ambientais do projeto e de suas alternativas;

III- definição das medidas mitigadoras dos impactos negativos;

IV- elaboração de programa de acompanhamento e monitoramento dos impactos positivos e negativos.

Também este artigo prevê, em parágrafo único, que o órgão ambiental fornecerá instruções adicionais conforme as peculiaridades do projeto e características ambientais da área.

Além dessa orientação geral com relação ao conteúdo do estudo de impacto ambiental e da possibilidade de instruções adicionais, a legislação federal não prevê a elaboração de termos de referência, apoiados na identificação das questões principais a ser abordadas no estudo. Desta forma, apoiados apenas na orientação federal, os estudos de impacto ambiental tenderiam a abranger um leque muito amplo de questões, comprometendo não somente prazos e custos, mas a própria objetividade da análise.

\subsubsection{Participação pública}

A Lei da Política Nacional do Meio Ambiente (Art. 10, $\S 1^{\circ}$ ) determinou que “os pedidos de licenciamento, sua renovação e a respectiva concessão serão publicados no jornal oficial do Estado, bem como em um periódico regional ou local de grande circulação”, consagrando o princípio da publicidade em matéria ambiental já presente em legislações estaduais editadas anteriormente. A Resolução Conama n⿳o 6/86 dá instruções para estas publicações, inclusive os itens que dela devem constar. Além da identificação da empresa, atividade, local e tipo de licença requerida, o anúncio deve informar se o estudo de impacto ambiental foi exigido ou não.

Com relação ao estudo de impacto ambiental, a Constituição Federal (Art. 225, § $1^{\circ}$, inciso IV) afirma que “...incumbe ao Poder Público: .......exigir, na forma da lei, para instalação de obra ou atividade potencialmente causadora de significativa degradação do meio ambiente, estudo prévio de impacto ambiental, a que se dará publicidade”. A publicidade dada aos pedidos de licença e ao estudo de impacto 
ambiental possibilita que a população afetada, ou simplesmente interessada, tenha conhecimento do processo.

Cabe aqui ressaltar a distinção que BENJAMIN (1992 apud MILARÉ; BENJAMIN, 1993) faz entre o princípio da publicidade e o princípio da participação pública; enquanto o primeiro trata do direito à informação, o segundo é mais amplo e refere-se ao direito de intervir no processo de tomada da decisão ambiental. A Resolução Conama n⿳0 $1 / 86$ busca atender aos dois princípios.

Essa intenção transparece, inicialmente, no Art. 9º (Parágrafo Único), que determina que as conclusões do estudo de impacto ambiental devem ser apresentadas em um relatório (Rima) especialmente preparado para o público leigo, redigido em linguagem acessível de modo a possibilitar a compreensão das vantagens e desvantagens do projeto, bem como das consequiências ambientais de sua implementação. Em seguida, no Art. 11, a norma garante o acesso público ao relatório, cujas cópias têm de ficar disponíveis para consulta em locais públicos. O sigilo industrial deve ser respeitado, mas somente quando solicitado e demonstrado pelo interessado. Finalmente, a resolução prevê a fixação de prazo para conhecimento dos comentários feitos pelos órgãos públicos e demais partes interessadas e, sempre que julgada necessária, a "realização de audiência pública para informação sobre o projeto e seus impactos ambientais e discussão do Rima” (Art. 11, § 2º $)$.

Nas palavras de MACHADO (1998), "há uma dupla caminhada na audiência: o órgão público presta informações ao público e o público passa informações à Administração pública”. As audiências públicas foram disciplinadas pela Resolução Conama n⿳0 9/87 que, apesar de aprovada em 1987, somente foi referendada e publicada em 1990, mais de dois anos depois, talvez justamente devido ao grande poder que este instrumento pode conferir às partes interessadas para influenciar nas decisões do poder público.

Diz a norma que a audiência pública tem por finalidade informar os presentes, dirimir suas dúvidas e recolher suas críticas e sugestões (Art. $1^{\underline{0}}$ ). Diz, ainda, que a ata da audiência pública, juntamente com o Rima, servirão de base para a análise e parecer final do licenciador (Art. $5^{\mathrm{o}}$ ). Deste modo, embora não tenham o poder de decidir sobre o projeto, as audiências públicas, realizadas na etapa de análise do EIA/Rima pelo órgão ambiental, revelam informações antes mantidas fora do alcance das partes interessadas, 
abrem um canal para manifestações do público e obrigam o poder público a considerálas.

A Resolução Conama n⿳o 9/87 inovou ao retirar dos órgãos ambientais competentes a competência privativa de convocar audiências públicas. Além da iniciativa do órgão ambiental, a audiência pública poderá ser realizada por solicitação de: (i) entidade civil, (ii) Ministério Público ou (iii) cinqüenta ou mais cidadãos (Art. $2^{\circ}$ ). Se, apesar de regularmente solicitada, a audiência não for realizada, a licença concedida não terá validade (Art. $2^{\underline{o}}, \S 2^{\underline{o}}$ ).

Com relação ao local de realização da audiência pública, deve ser acessível aos interessados, podendo ser necessário, de acordo com a localização geográfica dos solicitantes e da complexidade do tema, realizar mais de uma reunião (Art. $2^{\underline{o}}$, $\S 4^{\mathrm{o}} \mathrm{e}$ $5^{\circ}$ ). A título de ilustração, em edital publicado pelo Ibama convidando as partes interessadas a se manifestar a respeito do EIA/Rima da Hidrovia Tocantins-Araguaia, consta que cópias do Rima foram colocadas à disposição do público em nada menos do que 21 locais, distribuídos em 15 cidades, de cinco Estados e no Distrito Federal (BRASIL, 1999). Na ocasião, já haviam sido marcadas cinco audiências nos Estados do Maranhão, Tocantins, Pará, Mato Grosso e Goiás.

MACHADO (1998) entende que a norma não obriga o órgão ambiental a realizar várias audiências, mas o orienta, "com sabedoria, que estando os solicitantes em locais diferentes ou sendo a matéria complexa" esta prática é útil e aconselhável. Entende, ainda, o jurista que o órgão público tem o poder de decidir pela realização de uma ou mais audiências, mas fica obrigado a expor os motivos da sua decisão, já que o poder é discricionário, mas não arbitrário.

\subsection{AIA no Estado de São Paulo}

Nos termos do Art. $2^{\circ}$ da Resolução Conama 1/86, competem, em primeira instância, ao órgão ambiental estadual a aprovação do Estudo de Impacto Ambiental e o respectivo Relatório de Impacto Ambiental. No Estado de São Paulo, estas atribuições cabem à Secretaria do Meio Ambiente (SMA).

A compreensão e análise dos diversos problemas que permeiam a implementação da AIA no Estado, comprometendo sua eficácia, demandam o resgate dos principais eventos que resultaram na criação da Secretaria do Meio Ambiente (SMA), bem como das origens e funções dos principais órgãos que a integram. 


\subsubsection{A criação da Secretaria do Meio Ambiente (SMA)}

A Secretaria do Meio Ambiente foi criada pelo Decreto $\mathrm{n}^{\mathrm{o}}$ 24.932, de 24/03/86, e reestruturada, reorganizada e regulamentada três anos depois, pelo Decreto $\mathrm{n}^{\mathrm{o}} 30.555$, de 03/10/89, que lhe conferiu os contornos de sua estrutura atual (Figura 2.1). Esta estrutura abriga diversos organismos governamentais existentes antes da criação da SMA, que a ela se juntaram formando um mosaico de órgãos com missões, corpo técnico e procedimentos desenvolvidos e cristalizados em diferentes medidas.

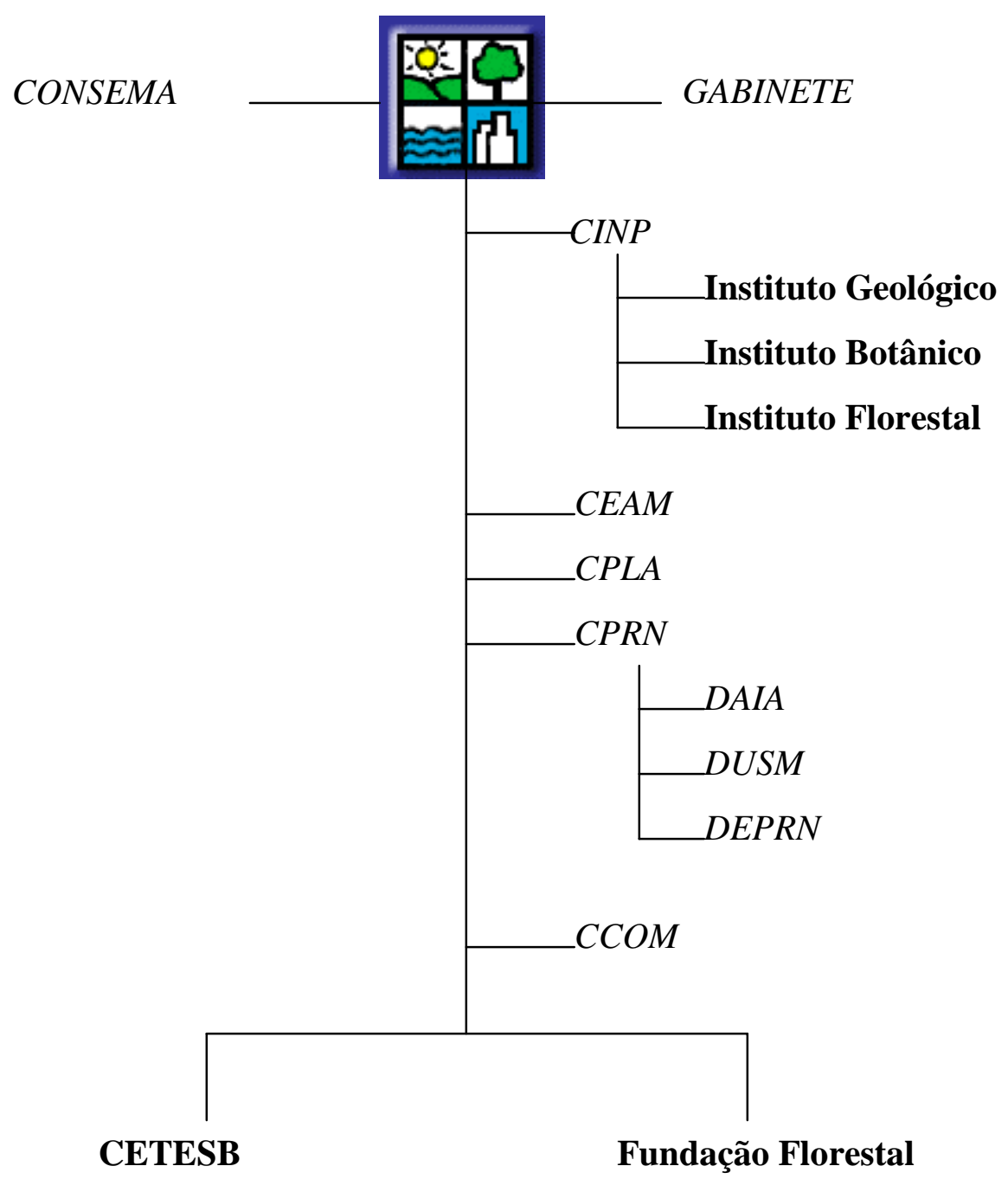

Figura 2.1: Organograma da Secretaria do Meio Ambiente Fonte: SÃO PAULO (2000a)

De acordo com SÃO PAULO (2000a), o Instituto Geológico, o Instituto Botânico e o Instituto Florestal, três dos mais renomados centros de pesquisa do País, 
reunidos na Coordenadoria de Informações Técnicas, Documentação e Pesquisa Ambiental (Cinp), são originários da Secretaria da Agricultura e Abastecimento.

A Coordenadoria de Educação Ambiental (Ceam) e a Coordenadoria de Planejamento Ambiental (CPLA) são oriundas de diretorias da Cetesb que desenvolviam programas de educação e planejamento (RONZA, 1998).

Também originária da Secretaria de Agricultura e Abastecimento, a Coordenadoria de Proteção de Recursos Naturais (CPRN), cuja denominação foi alterada pelo Decreto $\mathrm{n}^{\mathrm{o}}$ 40.046, de 13/04/95, para Coordenadoria de Licenciamento Ambiental e de Proteção de Recursos Naturais, abriga o Departamento Estadual de Proteção de Recursos Naturais (DEPRN), o Departamento de Licenciamento e Fiscalização do Uso do Solo Metropolitano (Dusm) e o Departamento de Avaliação de Impacto Ambiental (Daia), ambos anteriormente vinculados à CPLA. A Coordenadoria de Comunicação (CCOM) é responsável pelas relações entre a SMA e a população.

Além das coordenadorias e do Conselho Estadual do Meio Ambiente (Consema), vinculam-se à SMA, indiretamente, a Companhia de Tecnologia de Saneamento Ambiental (Cetesb) e a Fundação para a Conservação e a Produção Florestal do Estado de São Paulo (Fundação Florestal).

A Polícia Florestal e de Mananciais, vinculadas formalmente à Secretaria da Segurança Pública, estão funcionalmente ligadas à SMA, formando com os demais órgãos o Sistema Estadual do Meio Ambiente (Sisema), cujo coração é a Secretaria do Meio Ambiente (SÃO PAULO, 2000a).

Por sua participação destacada na aplicação dos procedimentos de AIA no Estado, o Consema, a Cetesb, o Daia, o Dusm e o DEPRN são analisados em detalhe a seguir. Dois destes órgãos em especial, a Cetesb e o DEPRN, por possuírem estrutura descentralizada, reúnem as melhores condições de atuação em todo o território do Estado. No total, a Cetesb tem 32 postos de atendimento e o DEPRN 24 equipes técnicas. As dificuldades de articulação de ações entre eles, no entanto, são agravadas por não adotarem a mesma divisão regional.

\section{Consema}

Criado em 1983, em sintonia com a bandeira "democracia e participação" adotada pelo governo recém eleito, o Conselho Estadual do Meio Ambiente (Consema), era presidido pelo Governador, vinculado ao seu gabinete, e tinha como conselheiros 
secretários de Estado, presidentes de órgãos e empresas do governo e representantes da sociedade civil (SÃO PAULO, 1993). Entre suas atribuições incluía-se a proposição de políticas, a elaboração de normas de controle de poluição, o estudo e a coordenação da implantação de áreas de proteção ambiental, o apoio à pesquisa científica e a promoção da educação ambiental.

Reformulado pelo Decreto $\mathrm{n}^{\mathrm{o}}$ 30.555/89, recebeu entre suas atribuições "apreciar relatórios de impacto sobre o meio ambiente, na forma da legislação" (Art. 115, alínea VIII). Ao contrário de versões amplamente difundidas, o Consema não é um colegiado deliberativo, mas sim consultivo, ou seja, não tem o poder de decisão sobre os EIAs e Rimas, uma vez que compete ao Secretário do Meio Ambiente "aprovar os Relatórios de Impacto Ambiental - Rimas, ouvido o Conselho Estadual do Meio Ambiente - Consema” (Decreto n⿳0 30.555/89, Art. 94, alínea II, item j). Embora não detenha formalmente este poder, o Consema o conquistou politicamente e suas deliberações têm sido acatadas pelos vários titulares da pasta de Meio Ambiente. De acordo com FURRIELA (1999), não existe na história do Consema caso em que um Secretário tenha emitido licença contrariando decisão do Conselho.

Atualmente, o Conselho é presidido pelo Secretário do Meio Ambiente e integrado por 35 membros assim distribuídos: 14 representantes de secretarias de Estado, um representante da Cetesb, um representante da CPLA, um representante da CPRN, um representante da Procuradoria Geral da Justiça do Estado e 17 representantes de organizações da sociedade civil. Dentre estes, figuram representantes da Federação das Indústrias do Estado de São Paulo (Fiesp), do Conselho Regional de Engenharia, Arquitetura e Agronomia do Estado de São Paulo (Crea/SP), da Associação Paulista de Municípios, da Ordem dos Advogados do Brasil - Seção São Paulo (OAB-SP), do Sindicato dos Trabalhadores Urbanos do Estado de São Paulo, da Universidade de São Paulo (USP), da Universidade Estadual Paulista “Júlio de Mesquita Filho" (Unesp), da Universidade Estadual de Campinas (Unicamp), da Sociedade Brasileira para o Progresso da Ciência (SBPC), do Instituto dos Arquitetos do Brasil - Seção São Paulo (IAB-SP), da Associação Brasileira de Engenharia Sanitária e Ambiental (Abes), além de seis representantes eleitos por "entidades com tradição na defesa do Meio Ambiente, 
regularmente cadastradas na Secretaria do Meio Ambiente" (Decreto no 30.555/89, Art. 116 .

Conforme esclarece FURRIELA (1999), o Consema desempenha suas funções por meio de reuniões ordinárias e extraordinárias do plenário, das câmaras técnicas, de comissões especiais e audiências públicas, todas abertas ao público. As normas do Consema prevêem sete câmaras técnicas com a atribuição de apreciar empreendimentos, projetos ou atividades submetidas à avaliação de impacto ambiental; porém, atualmente, funcionam apenas quatro: (i) empreendimentos industriais ou imobiliários e de projetos urbanísticos; (ii) energia, recursos hídricos e saneamento; (iii) mineração e empreendimentos agropecuários e (iv) sistemas de transporte.

A discussão e apreciação de empreendimentos sujeitos à aprovação de EIA e Rima, bem como sua aprovação ou reprovação, é atribuição das Câmaras Técnicas, a não ser que o Plenário avoque para si esta tarefa. Também cabe ao Consema a organização e condução das audiências públicas previstas no processo de AIA.

\section{Cetesb}

As origens da atual Companhia de Tecnologia de Saneamento Ambiental (Cetesb) remontam, de acordo com histórico resgatado por CLÁUDIO; KONO (1997), a 1968, quando foi criado o Centro Tecnológico de Saneamento Básico (Cetesb), subordinado à pasta de Serviços e Obras, com capacitação voltada para questões ligadas ao saneamento. Em 1973, as atividades e prerrogativas do Cetesb foram incorporadas pela recém-criada Companhia Estadual de Tecnologia de Saneamento Básico e Controle da Poluição das Águas (Cetesb), vinculada à mesma pasta. Em 1975, a denominação da empresa foi alterada para Companhia Estadual de Tecnologia de Saneamento Básico e de Defesa do Meio Ambiente (Cetesb) e a secretaria passou a chamar-se Secretaria de Obras e do Meio Ambiente (Soma). Segundo estas autoras, a transformação refletia uma ampliação do escopo de atuação da Companhia, de saneamento para saneamento ambiental, incorporando outros elementos do meio ambiente como o ar e o solo.

Com a promulgação da Lei no 997, de 31/05/76, instituiu-se em São Paulo o Sistema de Prevenção e Controle da Poluição do Meio Ambiente, introduzindo no

\footnotetext{
9 Alterações na composição do Consema foram introduzidas posteriormente pelos Decretos n ${ }^{\text {os }} 34.644 / 92$, 35.913/92 e 37.522/93.
} 
cenário brasileiro a figura do licenciamento ambiental de fontes de poluição, na forma das licenças de instalação e de funcionamento. O Decreto $n^{0} 8468$, que regulamentou a citada lei, atribuiu à Cetesb competência para sua aplicação, do seu regulamento e das normas decorrentes. Nesse mesmo ano, a Cetesb teve sua denominação alterada para Companhia de Tecnologia de Saneamento Ambiental, desta vez pela Assembléia Geral Extraordinária.

CLÁUDIO; KONO (1997) situam na primeira metade da década de 80 a incorporação pela Cetesb de uma abordagem preventiva para as questões ambientais. Foram desenvolvidos trabalhos visando ao planejamento de bacias, como o Zoneamento Ambiental da Bacia do Rio Paraíba do Sul, que envolveu, além de São Paulo, os Estados de Minas Gerais e Rio de Janeiro e resultou nas diretrizes expressas no Decreto Federal $n^{0}$ 87.561/82. Outro exemplo foi a elaboração da Carta do Meio Ambiente da Baixada Santista, reunindo informações sobre a situação ambiental da região de Cubatão, considerada como Área Crítica de Poluição nos termos da Lei Federal no 6803/80, dentro de uma linha de trabalho que visava a interpretar e tornar disponível ao público o importante acervo de dados acumulados pela Companhia. É nesse período que a Cetesb passou a contar com a Diretoria de Planejamento Ambiental (DPLAN) que viria, posteriormente, a abrigar a área encarregada de conduzir o processo de avaliação de impacto ambiental no Estado de São Paulo.

Atualmente, a Cetesb está organizada em quatro diretorias: (i) diretoria administrativa e financeira, (ii) diretoria de controle da poluição ambiental, (iii) diretoria de recursos hídricos e engenharia ambiental e (iv) diretoria de desenvolvimento e transferência de tecnologia. A Companhia dispõe de uma estrutura descentralizada, contando com numerosos postos de atendimento ao público. Além da sede, na cidade de São Paulo, possui oito agências na Região Metropolitana e seis regionais distribuídas no interior do Estado, cada uma delas com um certo número de agências distribuídas em alguns dos seus municípios de abrangência. No total são 23 agências no interior que, juntamente com as da Região Metropolitana e a sede, perfazem 32 postos de atendimento ao público em todo o Estado.

A prevenção e o controle da poluição do meio ambiente no Estado de São Paulo são as atribuições básicas da Cetesb. A abordagem preventiva dá-se por meio do licenciamento prévio de fontes das poluição ambiental, assim definidas no Decreto $\mathrm{n}^{\mathrm{o}} 8468 / 76$. No caso de obras ou atividades que, além de se enquadrarem no conceito de 
fonte de poluição, forem consideradas potencialmente causadoras de significativa degradação do meio ambiente e obrigadas a submeter-se ao processo de AIA, a Cetesb somente poderá emitir as licenças de instalação e de funcionamento após a outorga pela SMA da licença prévia.

No âmbito do processo de AIA, a Cetesb analisa os aspectos de poluição ambiental e fiscaliza o cumprimento dos condicionantes definidos no processo de licenciamento, dentro de sua área de competência — poluição do meio ambiente ou, mais precisamente, poluição das águas, do ar ou do solo.

\section{Daia}

Para atender às demandas criadas com edição da Resolução Conama $\mathrm{n}^{\mathrm{o}}$ 1/86, foi criada, no âmbito da Diretoria de Planejamento Ambiental (DPLAN) da Cetesb, a Gerência de Avaliação de Impacto Ambiental (Gaia), posteriormente subordinada à Superintendência de Avaliação Ambiental (SAA). CLÁUDIO; KONO (1997) chamam a atenção para o fato de que, embora vinculado à Cetesb, este núcleo surge fora do espaço físico da Companhia, caracterizando-se por sua integração com a SMA então emergente. Em 1989, a DPLAN é transferida para a SMA recebendo a denominação de Coordenadoria de Planejamento Ambiental (CPLA), e a SAA passa a chamar-se Daia.

Mais recentemente, em 1995, o Daia é transferido para a Coordenadoria de Licenciamento Ambiental e de Proteção de Recursos Naturais (CPRN), juntamente com o DEPRN e o Dusm. Muitos consideraram esta mudança sintomática de um fortalecimento do vínculo entre a AIA e o licenciamento, enfraquecendo ainda mais seu caráter de instrumento de planejamento.

O Daia atua no licenciamento de empreendimentos submetidos ao processo de Avaliação de Impacto Ambiental. Faz parte das atribuições deste Departamento a triagem das ações que devem ser submetidas ao processo completo de AIA, a definição do Termo de Referência (TR) para a elaboração do EIA e do Rima, a análise do EIA e do Rima e emissão do parecer técnico correspondente, e a emissão da licença prévia (LP), licença de instalação (LI) e licença de operação (LO). No caso de empreendimentos enquadrados como fonte de poluição nos termos do Decreto nº 8468/76, o Daia concede apenas a LP, sendo as licenças subseqüentes emitidas pela Cetesb. O Daia é responsável, ainda, pela análise dos Planos de Recuperação de Áreas Degradadas (Prads) exigíveis de empreendimentos de mineração. 
Apesar da complexidade e abrangência de sua atuação, o Daia não conta com estrutura descentralizada, concentrando todas as suas atividades na sede da SMA, na cidade de São Paulo.

O parecer do Daia é a principal referência utilizada pelos membros do Consema para sua apreciação da viabilidade ambiental do empreendimento. De modo geral, o Consema acompanha a recomendação contida no parecer do Daia, acrescentando exigências (medidas mitigadoras, compensatórias ou de monitoramento) às medidas propostas pelo requerente ou formuladas pelo Daia. Registra-se um único caso de divergência total entre a deliberação do Consema e a recomendação do Daia. Trata-se do projeto de implantação de uma pedreira na Região Metropolitana de São Paulo, que foi reprovado pelo Conselho em 1994, apesar da recomendação de aprovação dada pelo Daia (DIAS; SÁNCHEZ, 1999).

\section{Dusm 10}

O Dusm tem suas origens na Empresa Metropolitana de Planejamento da Grande São Paulo S.A. (Emplasa), que integrava o Sistema de Planejamento e de Administração Metropolitana (Spam), criado em 1974, no âmbito da Secretaria dos Negócios Metropolitanos (SNM), para coordenar as atividades governamentais de modo a assegurar o desenvolvimento integrado da Região Metropolitana de São Paulo (RMSP) (ANÔNIMO, 1980). Uma das atividades da Emplasa era a análise técnica dos empreendimentos a ser implantados nas áreas de proteção dos mananciais.

Esta ação passou a ser desenvolvida quando o Estado impôs a obrigatoriedade de manifestações prévias por parte da Cetesb e SNM para qualquer projeto de edificação e/ou urbanização situado na região. A análise técnica, exercida pela Emplasa por meio da Gerência de Análise e Controle de Projetos (GACP), verificava seu enquadramento na legislação de mananciais (Lei n⿳o 898, de 18/12/75; Lei n⿳ำ 1172, de 17/11/76 e Decreto $\mathrm{n}^{\mathrm{o}}$ 9714, de 19/04/77), que delimitava as áreas protegidas e fixava parâmetros de uso e ocupação do solo, como usos permitidos, ocupação máxima admissível e eficiência requerida para o tratamento dos efluentes líquidos. Articuladamente ao trabalho da Emplasa/GACP, as atividades de licenciamento e fiscalização eram

\footnotetext{
${ }^{10}$ As informações sobre as origens do Dusm foram fornecidas pelo Arquiteto Ubirajara Pereira Fontes, responsável pela Gerência de Análise e Controle de Projetos (GACP), da Emplasa, e pelo Engenheiro Aruntho Savastano, responsável pela Unidade Técnica de Licenciamento e Fiscalização da SDHU e Diretor do Dusm quando de sua criação na SMA.
} 
exercidas pela assessoria técnica da SNM, por meio da Unidade Técnica de Licenciamento e Fiscalização, que posteriormente incorporou as atribuições e equipes da GACP.

Em 1988, foi criada a Secretaria de Desenvolvimento Habitacional e Urbano (SDHU), que incorporou a SNM e, em 1991, pelo Decreto $\mathrm{n}^{\mathrm{o}} 33.135$, de 15/03/91, foram transferidas para a Secretaria do Meio Ambiente as atividades relativas ao controle e proteção dos mananciais. Para exercer estas atribuições, foi então criado o Departamento de Uso do Solo Metropolitano (Dusm), inicialmente vinculado à CPLA e posteriormente transferido para a CPRN, com a denominação alterada para Departamento de Licenciamento e Fiscalização do Uso do Solo Metropolitano. Vale destacar que, além das atribuições, foi transferida para a SMA a maioria dos profissionais que atuavam na área na SDHU.

Atualmente, o Dusm continua respondendo pelo licenciamento e fiscalização de atividades e empreendimentos situados em Áreas de Proteção de Mananciais da Região Metropolitana de São Paulo, inclusive aqueles submetidos ao processo de avaliação de impacto ambiental. Qualquer obra ou atividade proposta na região de sua atuação requer análise do Dusm, que expede o Alvará de Licença Metropolitana com Exigências Técnicas.

\section{DEPRN}

O DEPRN passou a integrar a estrutura da SMA quando a CPRN foi transferida da Secretaria da Agricultura e Abastecimento. Quando na pasta da Agricultura, a CPRN, então Coordenadoria de Pesquisa de Recursos Naturais, abrigava, além dos institutos Florestal, Geológico, Botânico e da Pesca, uma Divisão de Proteção de Recursos Naturais (DPRN) que, pouco antes da passagem para a pasta de Meio Ambiente, havia sido elevada à condição de departamento — Departamento Estadual de Proteção de Recursos Naturais (DEPRN)

Desde o início, a missão do DEPRN foi a de regular a questão do desmatamento no Estado, aplicando os preceitos expressos no Código Florestal para a autorização de supressão de vegetação nativa. A atuação do DEPRN foi responsável pela aplicação efetiva de vários dispositivos que, apesar de previstos no Código Florestal, até então não

\footnotetext{
11 As informações sobre as origens do DEPRN foram fornecidas pelo Engenheiro Agrônomo Paulo de Mello Schwenck, Diretor Geral do DEPRN no período 89/92.
} 
vinham sendo implementados. É o caso da reserva legal, cuja averbação à margem da inscrição de matrícula do imóvel, no registro de imóveis competente, já era exigida no Código Florestal desde 1965 (Lei n⿳ํㅗ 4771/65, Art. 16, § 2º̄) e mesmo assim, no início dos anos 80, encontrou fortes resistências para sua aplicação, até mesmo por parte dos cartórios.

Atualmente, o DEPRN participa do licenciamento das atividades e empreendimentos que envolvem supressão e/ou exploração de vegetação nativa, assim como intervenções em áreas de preservação permanente. Além disso, fiscaliza, em conjunto com a Polícia Florestal e de Mananciais, ações contra a fauna e a flora. No âmbito do processo de AIA, o DEPRN, em seu campo de competências, realiza vistorias de campo e elabora laudos técnicos, emitindo os seguintes documentos:

Atestado de Regularidade Florestal, Autorização para Supressão de Vegetação ou Termo de Indeferimento.

Nos casos em que a supressão de vegetação nativa ou intervenção em área de preservação permanente é autorizada, o DEPRN analisa as propostas de medidas compensatórias, especialmente a reposição florestal. Para o desempenho de suas funções, o DEPRN possui uma estrutura descentralizada, composta por 5 Diretorias Regionais e 24 Equipes Técnicas.

\subsubsection{Os procedimentos de AIA em São Paulo}

O principal dispositivo legal que regula os procedimentos de AIA no Estado de São Paulo é a Resolução SMA nº 42, de 29/12/1994. Esta norma é o resultado do trabalho da "Comissão especial para analisar os princípios, critérios e procedimentos relacionados ao processo de avaliação de impacto ambiental (AIA)", criada pelo Consema.

De acordo com FARIA (1998), esta comissão, ao longo de 30 reuniões, chegou às suas proposições finais por meio de um processo altamente participativo e de elevado nível técnico, tendo contado com a participação de representantes do Executivo estadual, do IAB, Fiesp, Crea, OAB, Abes, USP e membros da bancada ambientalista no Consema.

Além da minuta de resolução regulamentando os procedimentos para a avaliação de impacto ambiental no Estado de São Paulo, a referida comissão apresentou como resultado de seu trabalho duas outras minutas: a de um decreto instituindo a Avaliação 
Ambiental Estratégica e a de uma resolução SMA criando a Comissão de Avaliação Ambiental Estratégica. Com relação à AAE, embora tenha sido introduzida no contexto da AIA pela Resolução SMA nº 44/94 (publicada em 06/01/95), não houve continuidade no plano concreto. CLÁUDIO; KONO (1997), no entanto, previam sua aplicação em futuro próximo a planos voltados para a política de transportes na região metropolitana de São Paulo.

Ordenar os procedimentos de AIA no Estado era tarefa considerada essencial e inadiável para enfrentar os numerosos problemas que se acumulavam desde os primeiros anos da adoção deste instrumento no País. Um destes problemas, talvez o maior deles, advinha da exigência indiscriminada de EIA/Rima para todas as ações e atividades relacionadas no Art. $2^{\underline{0}}$ da Resolução Conama $n^{0}$ 1/86. Esta interpretação cautelosa das normas legais conduziu a um acúmulo de trabalho para as equipes multidisciplinares encarregadas de conduzir a etapa de análise dos estudos, dilatando desnecessariamente os prazos de processamento.

Paralelamente à questão do número de estudos, as equipes tiveram de enfrentar sérios problemas relativos à qualidade dos EIAs/Rimas apresentados. Havia desde estudos enciclopédicos e pouco objetivos, até aqueles que, produzidos em série para pequenos empreendimentos de mineração, deram origem à expressão "indústria do Rima” (SÁNCHEZ, 1990). Tudo isso era agravado pela precária articulação, senão conflito, entre os vários órgãos intervenientes no processo.

Ao ordenar os procedimentos de AIA no Estado, a Resolução SMA n $42 / 94$ logrou, principalmente: (i) articular as ações dos vários órgãos responsáveis por diversos aspectos do processo; (ii) formalizar os mecanismos de triagem de ações a ser submetidas à avaliação ambiental detalhada, bem como os de seleção das questões mais importantes a ser abordadas no estudo de impacto ambiental; e (iii) ampliar as possibilidades de participação do público no processo.

\section{Distribuição de competências}

Com relação à distribuição de competências, no caso geral coube ao Daia analisar o pedido de licença, instruído com o Relatório Ambiental Preliminar (RAP) e exigir ou não a apresentação do EIA/Rima; definir, com base em Plano de Trabalho proposto pelo interessado, um Termo de Referência (TR) para a elaboração do EIA/Rima; analisar o EIA e o Rima considerando as contribuições encaminhadas por 
interessados; emitir relatório sobre a qualidade técnica dos estudos, informando se demonstram a viabilidade ambiental do empreendimento e sugerindo condicionantes para as etapas posteriores do licenciamento; emitir a Licença Prévia (LP), quando o empreendimento for aprovado pelo Consema, e as licenças de Instalação (LI), Operação ou Funcionamento (LO ou LF), quando os condicionantes forem atendidos.

Nos casos em que o empreendimento, além de constar na listagem do Art. $2^{\underline{o}}$ da Resolução Conama $\mathrm{n}^{\mathrm{o}}$ 1/86, for considerado fonte de poluição nos termos do Decreto $\mathrm{n}^{\mathrm{o}}$ 8468/76, cabe à Cetesb receber o pedido inicial de licença e encaminhá-lo à SMA com as considerações preliminares pertinentes, bem como emitir as licenças de Instalação (LI) e de Funcionamento (LF), no final do processo.

Os demais órgãos irão se manifestar conforme a natureza dos impactos associados à proposta e sua localização. Ao DEPRN compete analisar propostas que incluem supressão e/ou exploração de vegetação nativa ou intervenções em áreas de preservação permanente, bem como as medidas compensatórias cabíveis, além de emitir as autorizações devidas. O Dusm participa do processo quando o empreendimento se localiza em Áreas de Proteção de Mananciais da Região Metropolitana de São Paulo.

Outros órgãos do sistema, ou mesmo fora dele, podem ser provocados e manifestar-se no decorrer do processo. É o caso dos projetos que requerem supressão de vegetação primária ou nos estágios avançado e médio de regeneração da Mata Atlântica, que somente pode ser autorizada mediante anuência prévia do Instituto Brasileiro do Meio Ambiente e dos Recursos Naturais (Ibama). Ou dos projetos que utilizam ou interferem nos recursos hídricos estaduais, como a extração de areia em leito de rio, que dependem da "Outorga para Implantação de Empreendimento" emitida pelo Departamento de Águas e Energia Elétrica (DAEE).

O Consema participa do processo de AIA principalmente em dois momentos: na definição do Termo de Referência quando o EIA/Rima é exigido e na aprovação final do empreendimento.

\section{Etapas iniciais}

Para subsidiar a triagem de ações que devem ser submetidas à avaliação ambiental detalhada, a Resolução SMA n⿳ำ 42/94 criou a figura do Relatório Ambiental Preliminar (RAP), que instrui o pedido de licença prévia. Na verdade, a avaliação ambiental preliminar já vinha sendo praticada informalmente desde o início dos anos 90 
para dispensar da elaboração do EIA/Rima projetos de pequeno porte ou cujos impactos fossem considerados não-significativos. Em alguns casos esta dispensa apoiava-se em normas específicas, que continuaram a ser editadas mesmo após a adoção do RAP (Quadro 2.2).

Como base para a elaboração dos RAPs, o Daia, apoiado em experiência acumulada na análise de vários tipos de empreendimento, elaborou uma série de roteiros básicos que, em linhas gerais, incluem: objeto do licenciamento, caracterização da ação ou empreendimento proposto, justificativa e alternativas locacionais e tecnológicas, diagnóstico ambiental preliminar da área de influência, identificação e avaliação dos impactos ambientais, medidas mitigadoras, compensatórias e de controle ambiental. São disponíveis roteiros básicos para elaboração de RAP para: sistemas de irrigação, sistemas de abastecimento de água, sistemas estruturais de drenagem, centrais hidrelétricas, distritos industriais, sistemas de transporte e armazenamento de combustíveis, sistemas de esgoto sanitário, estruturas de apoio a embarcações e a navegação de recreio, sistemas de tratamento e disposição final de resíduos sólidos, projetos urbanísticos, sistemas de transportes viários e termoelétricas. (SÃO PAULO, 1998)

Analisado o RAP, o Daia poderá indeferir o pedido de licença em razão de impedimentos legais ou técnicos, exigir a apresentação do EIA/Rima ou dispensá-la. A dispensa de apresentação de EIA/Rima, é bom lembrar, remete o projeto às etapas subseqüentes do licenciamento, que pode ser conduzido no próprio Daia, com base no RAP, ou na Cetesb, por meio de procedimentos próprios.

Para os casos em que a apresentação do EIA/Rima é exigida, a Resolução SMA $\mathrm{n}^{\mathrm{o}}$ 42/94 estabeleceu procedimentos para a definição das questões a ser abordadas no Estudo. Com base na análise de Plano de Trabalho elaborado pelo interessado, que deve explicitar a metodologia e o conteúdo dos estudos necessários; do RAP, que serviu de base para a exigência do Estudo; e de outras informações constantes do processo, em especial as manifestações das partes interessadas, o Daia define um Termo de Referência para a elaboração do EIA/Rima. A figura do TR já havia sido adotada na Resolução SMA no 26/93, para direcionar a avaliação ambiental detalhada de projetos de mineração. 


\begin{tabular}{|c|c|c|}
\hline NORMA & OBJETO & EXEMPLOS DE CRITÉRIOS DE EXIGÊNCIA \\
\hline $\begin{array}{l}\text { Deliberação } \\
\text { Consema n⿳⺈ } \\
20 / 90\end{array}$ & $\begin{array}{l}\text { Sistemas de } \\
\text { disposição de } \\
\text { resíduos sólidos } \\
\text { domiciliares, } \\
\text { industriais e de } \\
\text { serviços de saúde. }\end{array}$ & $\begin{array}{l}\text { Para resíduos sólidos domiciliares inertes: } \\
\text { - } \quad \text { até } 25 \text { t/dia— dispensa de EIA/Rima; } \\
\text { - } \quad \text { de } 25 \text { a } 100 \text { t/dia ou quando estiver em área de interesse } \\
\text { ambiental — avaliação ambiental preliminar } \\
\text { - } \quad \text { acima de } 100 \text { t/dia — exigência de EIA/Rima }\end{array}$ \\
\hline $\begin{array}{l}\text { Deliberação } \\
\text { Consema } n^{0} \\
44 / 90\end{array}$ & $\begin{array}{l}\text { Distritos industriais } \\
\text { e zonas de uso } \\
\text { estritamente } \\
\text { industrial. }\end{array}$ & $\begin{array}{l}\text { - } \text { ZEI I e ZEI II — exigência de EIA/Rima; } \\
\text { - } \quad \text { Zupi I e Zupi II com área igual ou superior a } 100 \text { ha - } \\
\text { exigência de EIA/Rima; } \\
\text { - } \quad \text { Zupi I e Zupi II com área inferior a } 100 \text { ha, que } \\
\text { produzam ou estoquem resíduos perigosos - avaliação } \\
\text { ambiental preliminar; } \\
\text { - Zupi I e Zupi II com área inferior a } 100 \text { ha, que não } \\
\text { produzam ou estoquem resíduos perigosos — dispensa de } \\
\text { EIA/Rima; } \\
\text { - ZUD I e ZUD II — dispensa de EIA/Rima; e } \\
\text { - Empreendimentos localizados ou nas proximidades de } \\
\text { áreas de interesse ambiental — avaliação ambiental } \\
\text { preliminar. }\end{array}$ \\
\hline $\begin{array}{l}\text { Resolução } \\
\text { SMA n }{ }^{-} \\
26 / 93\end{array}$ & $\begin{array}{l}\text { Empreendimentos } \\
\text { minerários }\end{array}$ & $\begin{array}{l}\text { - } \quad \text { Empreendimentos pequenos e médios, assim definidos } \\
\text { com base em área, volume de produção e tipo de substância } \\
\text { explorada - avaliação ambiental preliminar; } \\
\text { - } \quad \text { Empreendimentos grandes, ou seja, com área a licenciar } \\
\text { superior a } 100 \text { ha e produção mensal igual ou superior a } \\
5000 \mathrm{~m}^{3} / \mathrm{mês} \text { - exigência de EIA/Rima. }\end{array}$ \\
\hline $\begin{array}{l}\text { Resolução } \\
\text { SMA n }{ }^{-} \\
19 / 96\end{array}$ & $\begin{array}{l}\text { Sistemas urbanos de } \\
\text { esgotamento } \\
\text { sanitário. }\end{array}$ & $\begin{array}{l}\text { - } \text { municípios com população urbana de até } 5000 \text { habitantes } \\
\text { - dispensa de LP; } \\
\text { - } \quad \text { municípios com população urbana de } 5000 \text { a } 30.000 \\
\text { habitantes - dispensa de LP condicionada ao não- } \\
\text { enquadramento em situações listadas na norma; } \\
\text { - municípios com população urbana superior a } 30.000 \\
\text { habitantes - avaliação ambiental preliminar. }\end{array}$ \\
\hline $\begin{array}{l}\text { Resolução } \\
\text { SMA n⿳0 } \\
50 / 97\end{array}$ & $\begin{array}{l}\text { Aterros sanitários e } \\
\text { usinas de reciclagem } \\
\text { e compostagem de } \\
\text { resíduos sólidos } \\
\text { domésticos operados } \\
\text { por municípios. }\end{array}$ & $\begin{array}{l}\text { - até } 10 \text { t/dia, desde que não estejam localizados em área } \\
\text { de interesse ambiental - dispensa de LP e RAP; } \\
\text { - } \quad \text { de } 10 \text { a } 25 \text { t/dia - exigência ou dispensa de LP e RAP } \\
\text { decidida caso a caso pelo Daia; } \\
\text { - } \quad \text { acima de } 25 \text { t/dia - avaliação ambiental preliminar. }\end{array}$ \\
\hline $\begin{array}{l}\text { Resolução } \\
\text { SMA n⿳0 } \\
75 / 97 \\
\text { (Baseada na } \\
\text { Deliberação } \\
\text { Consema n } \\
41 / 94 \text { ) }\end{array}$ & $\begin{array}{l}\text { Estruturas de apoio a } \\
\text { embarcações. }\end{array}$ & $\begin{array}{l}\text { - } \quad \text { pequenas estruturas de apoio, assim definidas com base } \\
\text { no tipo de construção e número de embarcações que } \\
\text { comportam - dispensa de LP; } \\
\text { - } \quad \text { médias e grandes estruturas de apoio - avaliação } \\
\text { ambiental preliminar. }\end{array}$ \\
\hline $\begin{array}{l}\text { Resolução } \\
\text { SMA n⿳0 } \\
77 / 97\end{array}$ & Parques temáticos. & $\begin{array}{l}\text { - } \text { empreendimentos com capacidade de atendimento } \\
\text { superior a } 10.000 \text { pessoas/dia - exigência ou dispensa de } \\
\text { EIA/Rima baseada em avaliação ambiental preliminar. }\end{array}$ \\
\hline
\end{tabular}

\section{Quadro 2.2: Normas sobre exigência de EIA/Rima no Estado de São Paulo}

\footnotetext{
12 Os critérios de exigência de EIA/Rima para Distritos Industriais referenciam-se à classificação estabelecida pela Lei Estadual no n $^{5} 597 / 87$ que define as seguintes zonas: zona de uso estritamente industrial (ZEI), zonas de uso predominantemente industrial (Zupi) e zonas de uso diversificado (ZUD). Cada uma destas zonas pode ser do tipo I ou II, dependendo do tipo de indústria a que se destina e respectivo grau de risco ambiental associado.
} 


\begin{tabular}{|c|c|c|}
\hline NORMA & OBJETO & CRITÉRIOS DE EXIGÊNCIA \\
\hline $\begin{array}{l}\text { Resolução } \\
\text { SMA n⿳0 } \\
3 / 99\end{array}$ & $\begin{array}{l}\text { Empreendimentos } \\
\text { minerários. }\end{array}$ & $\begin{array}{l}\text { - empreendimentos localizados em zonas adequadas à } \\
\text { mineração devidamente aprovadas — dispensa de } \\
\text { EIA/Rima. }\end{array}$ \\
\hline $\begin{array}{l}\text { Resolução } \\
\text { SMA ñ } \\
4 / 99 .\end{array}$ & $\begin{array}{l}\text { Empreendimentos } \\
\text { minerários. }\end{array}$ & $\begin{array}{l}\text { - empreendimentos com área a licenciar inferior a } 100 \text { ha, } \\
\text { produção inferior a } 5000 \mathrm{~m}^{3} / \text { mês e voltados à exploração de } \\
\text { substâncias especificadas na norma - pode ser dispensado } \\
\text { de EIA/Rima pela Cetesb, ouvidos o DEPRN e Dusm, à luz } \\
\text { de critérios definidos na norma, ou remetido ao Daia; } \\
\text { - empreendimentos grandes, ou seja, com área a licenciar } \\
\text { superior a } 100 \text { ha e produção mensal igual ou superior a } \\
5000 \mathrm{~m}^{3} / \text { mês - exigência de EIA/Rima. } \\
\text { - demais empreendimentos - avaliação ambiental } \\
\text { preliminar. }\end{array}$ \\
\hline
\end{tabular}

\section{Quadro 2.2: Normas sobre exigência de EIA/Rima no Estado de São Paulo} Fonte: SÃO PAULO (1991a); SÃ̃ PAULO (1991b); LEGISLAÇÃO.... (1999a)

\section{Participação pública}

A Resolução SMA no $42 / 94$ inovou também ao antecipar e ampliar as possibilidades de participação pública no processo de AIA. Como o pedido de licença é publicado e os interessados podem manifestar-se por escrito no prazo de 30 dias contados da data da publicação, a primeira decisão da SMA — de indeferir o pedido, exigir a apresentação do EIA/Rima ou dispensá-la — já terá de considerar a participação pública. Esta decisão é obrigatoriamente publicada, assim como suas justificativas e a relação das petições recebidas.

No caso de ser exigida a apresentação do EIA/Rima, e esta é a maior inovação, "poderá ser pedida a realização de Audiência Pública ..." (Anexo da Resolução SMA $\mathrm{n}^{\mathrm{o}}$ 42/94, Parte I, Item 3.2). Esta audiência abre a possibilidade de manifestação das partes interessadas antes da definição do Termo de Referência. Deste modo, o órgão ambiental tem a oportunidade de avaliar a percepção do público a respeito dos prováveis impactos do projeto e incluir no escopo do EIA aspectos eventualmente não vislumbrados pelo proponente ou por seus técnicos. Ainda nesta fase, dependendo da magnitude e complexidade dos impactos ambientais do empreendimento, o Consema pode avocar a análise do TR, antes de sua definição pelo Daia.

A Resolução SMA nº 11/98 disciplina a matéria ao instituir a figura da "reunião técnica informativa ... no procedimento para a análise de estudos de impacto ambiental, de que trata a Resolução SMA $n^{\circ} 42 / 94$...” (Art. $1^{\underline{o}}$ ). Nos termos do Parágrafo Único desta Resolução, “compete ao Daia, à vista do teor das manifestações 
apresentadas, decidir sobre a conveniência e oportunidade da convocação da reunião, mediante decisão fundamentada”.

Com relação à etapa de análise do EIA/Rima, a Resolução SMA nº 42/94 remete às normas federal e estadual (Resolução Conama $n^{0}$ 9/87 e Deliberação Consema $n^{0}$ 50/92) as condições de realização de audiências públicas. Enquanto a norma federal, já comentada anteriormente, trata sucintamente (em seis artigos) de questões como competência para convocação, formas de convocação, prazos, publicidade, local de realização e tratamento das informações colhidas na audiência, a norma estadual é mais extensa (15 artigos), abordando, em linhas gerais, os mesmos temas, porém de forma bem mais detalhada.

As audiências públicas no âmbito do processo de AIA em São Paulo podem ser realizadas por iniciativa da própria SMA ou quando solicitadas pelo Poder Público Estadual ou Municipal, pelo Consema, pelo Ministério Público Federal ou Estadual, por entidade civil ou por cinqüenta ou mais cidadãos. Embora a Deliberação Consema $\mathrm{n}^{\text {o }}$ 50/92 faculte a convocação das audiências a dois grupos não contemplados na norma federal — o Poder Público e o Consema —, sua redação impõe condicionantes ausentes da Resolução Conama n⿳ 9/87 para os demais grupos. As entidades civis devem ser constituídas há mais de um ano e ter por finalidade social a defesa de interesse econômico, social, cultural ou ambiental, que possa ser afetado pela obra ou atividade objeto do EIA/Rima. Os cinqüenta ou mais cidadãos devem ter interesse legítimo potencialmente afetado pela obra ou atividade. Em todos os casos, a solicitação deve ser fundamentada, condição inexistente na norma federal. Esses condicionantes, ao menos em tese, conferem maior poder discricionário à SMA para decidir sobre a realização de audiências públicas.

Além das audiências públicas, todas as reuniões do Consema, tanto as do Plenário como as das Câmaras Técnicas, são abertas ao público que, no entanto, somente pode se manifestar se convidado por conselheiros.

Finalmente, com a edição da Resolução SMA nº 66/96, o Estado de São Paulo ampliou o acesso público à informação de natureza ambiental, obrigando todos os órgãos da administração a fornecer informações desta natureza quando solicitadas por escrito. Desta maneira, ao menos em tese, não apenas o Rima, mas todos os documentos relativos ao processo de AIA podem ser consultados por qualquer das partes 
interessadas. Isso inclui, em princípio, os processos administrativos no âmbito do DEPRN, Dusm, Daia e Cetesb, entre outros.

\subsection{Procedimentos de AIA aplicados à mineração no Estado de São Paulo}

No Estado de São Paulo, a mineração é atividade sujeita ao licenciamento ambiental pela Cetesb desde o advento da Lei no ${ }^{9}$ 997/76, regulamentada pelo Decreto $\mathrm{n}^{\mathrm{o}}$ 8468/76. A partir da edição da Resolução Conama $n^{0}$ 1/86, este licenciamento passou a depender de aprovação de EIA/Rima.

A primeira norma tratando especificamente de questões relacionadas à AIA de projetos de mineração editada no Estado foi a Resolução SMA nº 18, de 23/10/89, que disciplinava a obrigatoriedade de apresentação de Plano de Recuperação de Área Degradada (Prad) instituída pelo Decreto Federal no 97.632, de 10/04/89. Enquanto o Decreto limitava-se a ampliar o conteúdo obrigatório do EIA, de modo a garantir a recuperação das áreas degradadas pela atividade, e criar um instrumento próprio para tratar esta questão em empreendimentos já existentes, a Resolução foi mais específica, não reconhecendo o Prad como instrumento hábil para o licenciamento corretivo de empreendimentos devidamente licenciados pela Cetesb.

Esta diferença, sutil à primeira vista, teve grandes conseqüências na dinâmica de aplicação do processo de AIA ao setor mineral em São Paulo. Por esta norma, a exigência de EIA para empreendimentos de mineração ficou ainda mais estreitamente ligada à figura do licenciamento, ou seja, os empreendimentos minerários existentes, porém não devidamente licenciados pela Cetesb, ficavam sujeitos à exigência de EIA/Rima para obtenção da licença ambiental, apesar do caráter intrinsecamente prévio do instrumento.

Esta situação - empreendimentos minerários existentes, porém não devidamente licenciados pela Cetesb - era bastante comum na época, em decorrência de vários fatores relacionados ao perfil da economia do Estado de São Paulo. A Cetesb sempre foi mais atuante em questões ligadas ao saneamento e à poluição industrial, exercendo o controle ambiental da mineração apenas nos aspectos similares às indústrias. Assim, em muitos empreendimentos mineiros licenciados pela Cetesb antes da edição da Resolução Conama $\mathrm{n}^{\mathrm{0}}$ 1/86, as áreas licenciadas abrangiam somente as instalações de beneficiamento do minério, enfocando tão-somente a poluição do ar e da 
água. O despreparo era tão grande que muitos técnicos da Cetesb tratavam o avanço das frentes de lavra como ampliação do empreendimento.

Outro fator que contribuiu para que as licenças ambientais concedidas a empreendimentos minerários fossem imperfeitas foi a fórmula de cálculo do preço cobrado pelas licenças de instalação e funcionamento. As áreas construídas, de atividades ao ar livre e de lavra, compunham um dos fatores de cálculo do preço das licenças. Como as áreas de lavra eram muito grandes, da ordem de dezenas a centenas de hectares, o preço tornava-se muito alto quando comparado aos investimentos para a implantação do empreendimento. Por essa razão, muitas licenças foram concedidas para áreas de lavra menores do que as reais; o mais comum era a simples troca de unidades, ou seja, registrar como metros quadrados áreas expressas em hectares. Esta solução foi oficialmente adotada posteriormente e ainda hoje faz parte dos procedimentos de cálculo do preço das licenças de instalação e de funcionamento de empreendimentos minerários.

Todos esses empreendimentos não podiam ser considerados devidamente licenciados pela Cetesb e sua regularização passou a depender da apresentação de EIA/Rima. Nesta mesma época, começava a surtir efeito o dispositivo introduzido pela Lei Federal n 7105 , de 18/07/89, pelo qual a concessão de lavra passou a depender de prévio licenciamento do órgão ambiental, e vários empreendimentos minerários instalados irregularmente perante os órgãos ambientais passaram a requerer licença e apresentar EIA/Rima. O resultado foi desastroso; até o ano de 1991, dos 347 EIAs protocolizados na SMA, nada menos do que 212, ou seja, 61,1\% referiam-se a minerações (RONZA, 1998).

A partir da edição da Resolução Conama n⿳ำ 10/90, que possibilitava, no caso de empreendimentos minerários sujeitos ao regime de licenciamento, a dispensa da apresentação de EIA/Rima, a critério do órgão ambiental competente, em função da natureza, localização, porte e demais peculiaridades, o Daia passou a realizar a triagem dos projetos de mineração para os quais a análise detalhada era necessária. Com base em informações constantes no processo de licenciamento da Cetesb, o Daia exigia o EIA/Rima ou dispensava sua apresentação, requerendo o Relatório de Controle Ambiental (RCA) e o Plano de Controle Ambiental (PCA), nos termos da Resolução Conama $\mathrm{n}^{\mathrm{o}}$ 10/90. 
Posteriormente, quando já havia ganho credibilidade a interpretação de que a listagem constante no Art. $2^{\underline{o}}$ da Resolução Conama $n^{\underline{o}}$ 1/86 era meramente exemplificativa, os procedimentos de triagem foram estendidos a todos os empreendimentos minerários, independentemente da natureza do minério.

\subsubsection{A Resolução SMA no ${ }^{26 / 93}$ e a evolução dos critérios de triagem}

Ciente da necessidade de formalizar os procedimentos de AIA para o setor mineral, o Consema criou, em abril de 1992, a Comissão Especial para estudar a proposta de normas elaborada pelo Daia "Empreendimentos Minerários - Critérios para Exigência de EIA/Rima — Roteiros para Elaboração". Integravam a comissão, que posteriormente ficou conhecida como Comissão de Mineração, os representantes do Crea, Cetesb, CPLA, CPRN, Abes, Fiesp, OAB, Unesp, Secretaria de Planejamento e Gestão, Secretaria de Ciência, Tecnologia e Desenvolvimento Econômico, e os ambientalistas Condesmar Fernandes de Oliveira e João Paulo Capobianco (SÃO PAULO, 1993).

Os trabalhos da Comissão iniciaram-se, na prática, em dezembro de 1992 e estenderam-se até julho de 1993; foram 16 reuniões, uma visita técnica a minerações do Vale do Paraíba, e três palestras proferidas por convidados. 1.7 resultado, consolidado no relatório "Critérios de Exigência de EIA/Rima para Empreendimentos Minerários e Outras Providências", foi aprovado pelo plenário do Consema em 6/08/93 (Deliberação $\mathrm{n}^{\mathrm{o}}$ 22/93). A minuta de resolução SMA, que integrava o referido relatório, constituiu a base para a edição, em 30/08/93, da Resolução SMA nº 26/93, que passou a nortear não somente a etapa de triagem de projetos, mas todo o licenciamento ambiental de empreendimentos minerários no Estado.

\footnotetext{
${ }^{13}$ Muitas das informações a respeito dos trabalhos desta comissão provêem de anotações pessoais da autora, que na época era responsável pela área de triagem de projetos do Daia, e teve a oportunidade de participar da comissão na condição de convidada, tendo integrado o grupo responsável pela articulação e redação dos documentos que compuseram o relatório final.

Além dos conselheiros membros do Consema, participaram da comissão como convidados: Ricardo Ferraz (ambientalista); Antonio Carlos Lemos e Julian G. A. Almeida (Instituto Geológico); Francisco T. Van Acker (SMA); Aruntho Savastano Neto (Dusm); Ayrton Sintoni (Associação Paulista de Engenheiros de Minas); Hilda Renk Teixeira, Elvira Gabriela C. S. Dias e Marisa M. Teixeira (Daia); Marcos Sogabi e Geraldo do Amaral Filho (Cetesb); José Antonio Branquinho (Fiesp); Herbert Schulz (DEPRN); Dirceu Micheli e Claudio Bolzani (Dusm); Zelma Cincotto (SAR) e Rita de Cassia Ogera (Secretaria do Verde e do Meio Ambiente, da Prefeitura Municipal de São Paulo).

${ }^{14}$ O Prof. Dr. Luis Enrique Sánchez (Epusp) proferiu palestra sobre mineração e meio ambiente, a Profa Tania Saucen (Inpe) apresentou os resultados de trabalho de monitoramento da extração de areia do canal do rio Paraíba do Sul por fotografias aéreas e o Eng ${ }^{\circ}$ Aruntho Savastano (Dusm) expôs o funcionamento do Grupo de Aprovação de Projetos Habitacionais (Grapohab).
} 
Com relação à exigência de EIA/Rima, ficou estabelecido que:

"Artigo $7^{o}$ - A licença estará condicionada à aprovação de EIA/Rima sempre que ocorrer qualquer das seguintes situações:

I - Não houver informações suficientes para demostrar a existência de alternativas tecnológicas capazes de adequar o projeto aos padrões de qualidade ambiental vigentes;

II - O aproveitamento do recurso mineral implicar a apropriação de um outro recurso de interesse ambiental;

III - Houver incompatibilidade de relevância social com seu entorno;

$I V$ - Houver adensamento de empreendimentos, províncias ou distritos minerários que possa causar esgotamento da capacidade de suporte do meio;

$V$ - O empreendimento for considerado grande nos termos do Artigo $1^{\underline{o}}$ desta resoluçã ${ }^{15}$."

Como se vê, a norma estabeleceu um único critério de corte definido, ou seja, a apresentação de EIA/Rima tornou-se obrigatória para grandes empreendimentos. São considerados grandes os empreendimentos que possuem área total a licenciar igual ou superior a 100 ha ou cuja produção for igual ou superior $5000 \mathrm{~m}^{3} / \mathrm{mês}$. Para os demais, coube ao Daia, em articulação com o DEPRN, com a Cetesb e com o Dusm, quando a lavra estiver na Região Metropolitana de São Paulo, decidir, baseado nas informações fornecidas no RCA e balizado pelos critérios expressos no Art. $7^{\circ}$, se a apresentação de EIA/Rima deve ser exigida ou dispensada.

A Resolução SMA n 26/93 instituiu, ainda, a figura do termo de referência: “ $O$ EIA/Rima deve sempre ser precedido de um termo de referência que permita direcionar os estudos para os aspectos que o suscitaram” (Art. 7ํㅗㅁ, Parágrafo Único).

A Comissão de Mineração propôs, ainda, alterações no processo de licenciamento, integrando as ações do DEPRN, CPLA e Cetesb. A proposta, referendada pelo Consema, recomendava a instituição, no âmbito da SMA, de um sistema de análise e aprovação de empreendimentos minerários que reunisse CPLA, DEPRN e Cetesb para decidirem sobre o licenciamento das atividades minerárias. (SEARA FILHO, 1998).

Os critérios de triagem foram mantidos em sua essência nos regulamentos editados posteriormente - Resolução SMA nº 50/95 e Resolução SMA nº 66/95 -, que trataram mais da articulação entre os órgãos do sistema. Especificamente com

\footnotetext{
${ }^{15}$ A classificação dos empreendimentos minerários aqui referida encontra-se, na verdade, no Art. $2^{\underline{0}}$ da Resolução.
} 
relação à apresentação de EIA/Rima, essas normas abriram a possibilidade da Cetesb, considerando o parecer do DEPRN e os critérios de triagem, dispensar empreendimentos considerados pequenos e médios nos termos da Resolução nº 26/93. São considerados "pequenos e médios" os empreendimentos voltados à extração de minérios sujeitos ao regime de licenciamento e água mineral, desde que a produção seja inferior a $5000 \mathrm{~m}^{3} / \mathrm{mês}$ e a área total a licenciar seja inferior a 100 ha.

Mais recentemente, com a edição da Resolução SMA no 3/99, foi acrescentado um novo e importante critério de dispensa. Diz seu Art. 1ํㅜ "Não se exigirá a apresentação de EIA/Rima para os licenciamentos de empreendimentos minerários a serem localizados em áreas adequadas ao desenvolvimento dessa atividade, conforme estabelecido em zoneamento minerário regularmente aprovado”.

Editada juntamente com a anterior, a Resolução SMA n⿳0 4/99 trata da articulação entre os diversos órgãos que participam do licenciamento ambiental da mineração, bem como da adequação deste aos procedimentos de autorização para extração de bens minerais exercido pela União. Em outras palavras, esta Resolução trata da compatibilização entre os licenciamentos ambiental e minerário no Estado. Os critérios de dispensa da apresentação de EIA/Rima definidos na Resolução SMA nº 26/93 são mantidos, assim como a possibilidade de a Cetesb dispensar empreendimentos considerados pequenos e médios, aberta pela Resolução SMA $\mathrm{n}^{\mathrm{o}}$ 50/95. É a seguinte a redação dada pela Resolução SMA no 4/99 aos critérios de triagem a ser aplicados pela Cetesb nas condições estipuladas:

“Artigo 8 - Após a Cetesb ter recebido o "Parecer Técnico para Mineração" elaborado pelo DEPRN, serão dispensados de EIA/Rima os empreendimentos que atenderem simultaneamente aos requisitos abaixo descritos:

I - Não existirem impedimentos legais para sua implantação ou houver anuência prévia do órgão competente;

II - Houver condições técnicas para adequação às normas e padrões ambientais, tais como Normas Cetesb elou exigências fixadas pelo DEPRN, no âmbito de suas atribuições;

III - O meio tiver condições de suportar o impacto adicional, aplicadas as medidas mitigadoras, tais como não incidir em situações de adensamento, apropriação de outro recurso natural, como a água em $A P M$, solos de alta produtividade agrícola, vegetação remanescente significativa e outras consideradas relevantes regionalmente;

IV - Não existirem conflitos inconciliáveis de caráter social entre o empreendimento e seu entorno, tais como os decorrentes de sua situação 
em áreas urbanizadas ou próximas a instalações e equipamentos que possam ser afetados.

Parágrafo $1^{0}$ - Nas situações previstas no Artigo $1^{\circ}$ da Resolução SMA $n^{\underline{0}}$ 3, de 22/01/99, será dispensada a apresentação de EIA/Relatório de Impacto Ambiental.

Parágrafo $2^{\circ}$

Parágrafo $3^{\circ}$ - Nas situações não previstas no caput deste Artigo, e havendo dúvidas a serem dirimidas, a Cetesb remeterá o processo ao Daia para decisão sobre a dispensa ou não da apresentação do EIA/Rima."

Se a triagem é conduzida pelo Daia, seja porque o projeto não se enquadra nas condições estipuladas para ser analisado pela Cetesb, seja porque a Cetesb opta por remetê-lo ao Daia para decisão, valem os critérios fixados na Resolução SMA nº 26/93.

\subsubsection{AIA aplicada a múltiplos projetos de mineração e zoneamento minerário}

Outra abordagem adotada pelo Daia para contornar o problema do adensamento de pequenos empreendimentos minerários em determinadas áreas do Estado, foi o estímulo ao desenvolvimento de estudos de impacto ambiental abrangendo vários empreendimentos localizados em áreas próximas. O primeiro EIA conjunto aprovado pela SMA foi apresentado em março de 1989 pela Associação das Indústrias de Mineração e Extração de Areia do Vale do Paraíba (Aimea I) e abrangia 22 portos de areia no município de Jacareí. Foi aprovado em setembro de 1991, originando o Plano de Gestão Aimea I, aplicado à mineração de areia no leito e várzea do rio Paraíba do Sul. Em deliberação complementar (Deliberação Consema nº 36C/91), o Consema determinou que as exigências gerais fixadas no "Plano de Gestão Aimea I" deveriam ser aplicadas, "na medida do possível" (SÃO PAULO, 1993) na análise de todos os EIAs/Rimas relativos a atividades de extração de areia no Vale do Paraíba.

Esse foi o embrião do processo de estabelecimento de normas para disciplinar as atividades minerárias no Vale do Paraíba, que culminou na edição da Resolução SMA $\mathrm{n}^{-}$42/96. Esta Resolução condicionou o licenciamento ambiental para extração de areia na Bacia Hidrográfica do rio Paraíba do Sul à prévia definição de áreas aptas para essas atividades, ou seja, a um zoneamento minerário; e definiu medidas operacionais padrão para a mitigação de impactos e recuperação de áreas degradadas na bacia.

Em novembro de 1993, a Prefeitura Municipal de Araçariguama apresentou à SMA o EIA do Distrito Minerário de Araçariguama, abrangendo 11 portos de areia em funcionamento e dois projetados. Foi aprovado em abril de 1996. 
Em abril de 1997 foi a vez da aprovação do EIA da Associação dos Extratores de Areia e Argila Vermelha da Bacia do Rio Jaguari Mirim, nos municípios de Aguaí e São João da Boa Vista. O estudo abrangia 45 empreendimentos em funcionamento, foi apresentado em outubro de 1993 e serviu para embasar a Resolução SMA nº 69/97 que fixa medidas padrão de controle ambiental para as atividades de extração em cava e em leito de rio na bacia.

Finalmente, com a edição da Resolução SMA nº 3/99, já comentada, ficou estabelecido que os empreendimentos minerários localizados em zonas de mineração podem ser licenciados com dispensa de EIA/Rima. A norma determina, ainda, que a definição de áreas aptas à mineração, ou seja, o zoneamento minerário, deve “incorporar parâmetros de avaliação de impactos ambientais", que especifica; e que a proposição de zonas de mineração deve ser submetida ao Consema, garantida a realização de audiências e outros mecanismos de participação pública previstos na Resolução SMA no 42/96. Em suma, embora não empregue textualmente estas palavras, a Resolução SMA nº 3/99 institui a AIA para a criação de zonas de mineração, o que não deixa de ser um plano de uso do solo.

\subsubsection{Principais normas legais incidentes sobre a atividade de mineração no Estado de São Paulo}

O Quadro 2.3 apresenta as principais normas legais aplicáveis aos projetos de mineração no Estado de São Paulo. São incluídos os principais dispositivos da chamada legislação minerária, ou seja, a que disciplina o acesso aos recursos minerais, considerados bens da União (Constituição Federal, Art. 20, alínea IX).

\begin{tabular}{|c|c|}
\hline \multicolumn{2}{|r|}{ NORMAS FEDERAIS } \\
\hline NORMA & ASSUNTO \\
\hline $\begin{array}{l}\text { Lei } \mathrm{n}^{\mathrm{o}} 4771 / 65 \text { - Código } \\
\text { Florestal (Alterada pelas leis } \\
\mathrm{n}^{\text {os }} 5106 / 66,5868 / 72,5870 / 73 \\
7803 / 89,7875 / 89,1282 / 94 \mathrm{e} \\
9605 / 98)\end{array}$ & $\begin{array}{l}\text { Estabelece limitações ao uso das florestas e demais formas de } \\
\text { vegetação existentes no território nacional. }\end{array}$ \\
\hline $\begin{array}{l}\text { Decreto Lei n⿳0 227/67 - } \\
\text { Código de Mineração (Alterado } \\
\text { pelas leis nos } 6403 / 76,6567 / 78, \\
7085 / 82,7805 / 89,8901 / 94 \text { e } \\
9314 / 96 \text { ) }\end{array}$ & $\begin{array}{l}\text { Dispõe sobre a competência da União em administrar os recursos } \\
\text { minerais, entre outros. }\end{array}$ \\
\hline
\end{tabular}

(continua)

\section{Quadro 2.3: Principais normas legais incidentes sobre a atividade de mineração no Estado de São Paulo}


(continuação)

\begin{tabular}{|c|c|}
\hline \multicolumn{2}{|r|}{ NORMAS FEDERAIS } \\
\hline NORMA & ASSUNTO \\
\hline $\begin{array}{l}\text { Lei } \mathrm{n}^{\mathrm{o}} 6567 / 78 \text { (Alterada pela } \\
\left.\text { Lei } \mathrm{n}^{\mathrm{o}} 8982 / 95\right)\end{array}$ & $\begin{array}{l}\text { Dispõe sobre o regime especial para exploração e } \\
\text { aproveitamento das substâncias minerais. }\end{array}$ \\
\hline $\begin{array}{l}\text { Lei } \mathrm{n}^{\mathrm{o}} 6938 / 81 \text { - Lei da } \\
\text { Política Nacional do Meio } \\
\text { Ambiente (Alterada pelas leis } \\
\mathrm{n}^{\mathrm{os}} 7804 / 89,8028 / 90 \text { e } \\
9605 / 98)\end{array}$ & $\begin{array}{l}\text { Dispõe sobre a Política Nacional do Meio Ambiente, seus fins e } \\
\text { mecanismos de formulação e aplicação. }\end{array}$ \\
\hline \multicolumn{2}{|l|}{ Constituição Federal de 1988} \\
\hline Lei $\mathrm{n}^{\mathrm{o}}$ 7805/89 & $\begin{array}{l}\text { Altera o Código de Mineração. Destaque especial para os artigos: } \\
16 \text { a } 20\end{array}$ \\
\hline $\begin{array}{l}\text { Lei } n^{0} 9605 / 98-\text { Lei dos } \\
\text { Crimes contra o Meio } \\
\text { Ambiente }\end{array}$ & $\begin{array}{l}\text { Dispõe sobre as sanções penais e administrativas derivadas de } \\
\text { condutas e atividades lesivas ao meio ambiente. }\end{array}$ \\
\hline Decreto $n^{\circ} 97.632 / 89$ & Cria o Plano de Recuperação de Área Degradada. \\
\hline Decreto $\mathrm{n}^{\mathrm{0}} 98.812 / 90$ & Regulamenta a Lei no $7805 / 89$. Destaque para os artigos 18 e 19. \\
\hline Resolução Conama n⿳0 1/86 & Regulamenta a exigência de EIA/Rima. \\
\hline Resolução Conama n⿳ำ 9/90 & $\begin{array}{l}\text { Estabelece normas específicas para o licenciamento ambiental de } \\
\text { extração mineral das classes I, III, IV, V, VI, VII,VIII e IX. }\end{array}$ \\
\hline Resolução Conama nº 10/90 & $\begin{array}{l}\text { Estabelece normas específicas para o licenciamento ambiental de } \\
\text { extração mineral da classe II. }\end{array}$ \\
\hline $\begin{array}{l}\text { Portaria do Diretor Geral do } \\
\text { DNPM } \mathrm{n}^{-} 148 / 80\end{array}$ & $\begin{array}{l}\text { Estabelece normas sobre a instrução do requerimento do registro } \\
\text { de licença. }\end{array}$ \\
\hline \multicolumn{2}{|r|}{ NORMAS ESTADUAIS } \\
\hline Lei $n^{0} 898 / 75$ & $\begin{array}{l}\text { Dispõe sobre o uso do solo para a proteção dos mananciais e } \\
\text { recursos hídricos de interesse da Região Metropolitana de São } \\
\text { Paulo. }\end{array}$ \\
\hline Lei $\mathrm{n}^{\circ}$ 997/76 & Dispõe sobre o controle da poluição do meio ambiente. \\
\hline $\begin{array}{l}\text { Lei no 9509/97 (ainda não } \\
\text { regulamentada) }\end{array}$ & $\begin{array}{l}\text { Dispõe sobre a Política Estadual do Meio Ambiente, seus fins, } \\
\text { mecanismos de formulação e aplicação. }\end{array}$ \\
\hline Decreto $\mathrm{n}^{\mathrm{0}} 8468 / 76$ & Aprova o regulamento da Lei $\mathrm{n}^{\mathrm{o}}$ 997/76 \\
\hline Resolução SMA nº 18/89 & Dispõe sobre o Plano de Recuperação de Área Degradada \\
\hline Resolução SMA nº 26/93 & $\begin{array}{l}\text { Estabelece critérios para exigência de EIA/Rima para fins de } \\
\text { licenciamento. }\end{array}$ \\
\hline $\begin{array}{l}\text { Resolução SMA nº 50/95 } \\
\text { (REVOGADA) }\end{array}$ & $\begin{array}{l}\text { Dispõe sobre o licenciamento ambiental de empreendimentos } \\
\text { minerários. }\end{array}$ \\
\hline $\begin{array}{l}\text { Resolução SMA nº 66/95 } \\
\text { (REVOGADA) }\end{array}$ & $\begin{array}{l}\text { Disciplina a tramitação dos pedidos de licença ambiental para os } \\
\text { empreendimentos minerários. }\end{array}$ \\
\hline Resolução SMA nº 42/94 & Dispõe sobre os procedimentos de análise de EIA/Rima. \\
\hline Resolução SMA nº 42/96 & $\begin{array}{l}\text { Dispõe sobre a extração de areia na bacia hidrográfica do rio } \\
\text { Paraíba do Sul. }\end{array}$ \\
\hline Resolução SMA nº 69/97 & $\begin{array}{l}\text { Dispõe sobre a extração de areia e argila vermelha na bacia } \\
\text { hidrográfica do rio Jaguari Mirim. }\end{array}$ \\
\hline Resolução SMA nº 3/99 & $\begin{array}{l}\text { Dispõe sobre os procedimentos para o licenciamento ambiental } \\
\text { de atividades minerárias e zoneamento minerário. }\end{array}$ \\
\hline Resolução SMA nº 4/99. & $\begin{array}{l}\text { Dispõe sobre os procedimentos para o licenciamento ambiental } \\
\text { integrado de atividades minerárias. }\end{array}$ \\
\hline
\end{tabular}

Quadro 2.3: Principais normas legais incidentes sobre a atividade de mineração no Estado de São Paulo

Fonte: SÃO PAULO (1999); LEGISLAÇÃO...(1999a e 1999b). 
Capítulo 3

\section{A MINERAÇÃO NO ESTADO DE SÃO PAULO E SEUS IMPACTOS NO MEIO AMBIENTE}

Os impactos da mineração no meio ambiente são mencionados na literatura há pelo menos quatro séculos. Sobre este tema, o estudioso Georgius Agricola registrou em seu tratado, editado pela primeira vez em 1556, o seguinte comentário:

"O mais forte argumento dos detratores é que os campos são devastados pela mineração.... as florestas são cortadas, pois há necessidade de uma quantidade interminável de madeira para o escoramento das galerias e para a fundição dos metais. E quando as florestas são derrubadas, então são exterminados os animais e os pássaros, muitos dos quais provem uma agradável comida para o homem. Ademais, quando os minérios são lavados, a água que foi usada envenena os riachos e rios, e até destrói os peixes ou os afugenta ... Assim, dizem, é claro para todos que ocorrem maiores danos devido à mineração do que o valor dos metais produzidos." (AGRICOLA, 1950 apud SÁNCHEZ

Tais considerações referiam-se, basicamente, à mineração de minérios metálicos, lavrados em minas subterrâneas, em escalas incomparavelmente inferiores às atuais. Desde aí, o consumo global cresceu pelo menos 30 vezes (YOUNG, 1992) e a produção de alguns minerais em 1990 chegou a representar 22.000 vezes a taxa do ano de 1700. O Quadro 3.1 mostra a escala de produção de algumas substâncias minerais no ano de 1990.

Mesmo em comparações entre períodos mais recentes, o crescimento das escalas de produção do setor mineral é expressivo. Gigantescas minas a céu aberto foram implantadas, ocupando áreas cada vez maiores. As dimensões dos equipamentos saltaram, em 10 anos (de 1960 a 1970), de 20-40t para 80-200t, no caso de caminhões utilizados em mineração de rocha dura, ou de $2 \mathrm{~m}^{3}$ para $18 \mathrm{~m}^{3}$, no caso de alguns tipos de escavadeiras (YOUNG, 1992). 


\begin{tabular}{|l|r|l|}
\hline $\begin{array}{c}\text { SUBSTÂNCIA } \\
\text { MINERAL }\end{array}$ & $\begin{array}{r}\text { PRODUÇÃO } \\
(\mathbf{1 . 0 0 0} \mathbf{t})\end{array}$ & COMENTÁRIOS \\
\hline Metálicos & 552.000 & $\bullet 22.000$ vezes a taxa do ano de 1.700 \\
\multicolumn{1}{|c|}{$\bullet$ Gusa } & 18.100 & $\bullet$ •não utilizado em larga escala até 1886 \\
$\bullet$ Alumínio & 8.920 & $\bullet 560$ vezes a taxa do ano de 1.800 \\
$\bullet$ Cobre & 7.300 & $\bullet 7.300$ vezes a taxa do ano de 1.800 \\
$\bullet$ Zinco & 11.000 .000 & \\
\hline Não-metálicos & 9.000 .000 & \\
$\bullet$ Rochas & 500.000 & \\
$\bullet$ Areia & 191.000 & \\
$\bullet$ Argila & 166.350 & \\
$\bullet$ Sal & 135.300 & \\
$\bullet$ Rocha fosfática & $\bullet$ Calcário &
\end{tabular}

Quadro 3.1: Produção mundial de alguns minerais em 1990

Fonte: YOUNG, 1992 (modificado)

Em conseqüência, a mineração, embora não seja a única atividade a camsar danos ao meio ambiente, nem tampouco a que ostenta o maior passivo ambiental ${ }^{1+}$, é fortemente associada pela opinião pública à deterioração ambiental. Em pesquisa realizada no Brasil (SANTOS; MAZZON, 1995), em 1995, a mineração ocupava o quinto lugar entre as indústrias consideradas mais agressivas ao meio ambiente pela população em geral.

\begin{tabular}{|l|c|l|c|}
\hline \multicolumn{1}{|c|}{ TIPO DE ATIVIDADE } & $\boldsymbol{\%}$ & \multicolumn{1}{c|}{ TIPO DE ATIVIDADE } & $\%$ \\
\hline Extração de madeira & 62,9 & Indústria da pesca & 11,3 \\
Indústria química & 60,9 & Indústria farmacêutica & 9,0 \\
Indústria do papel e da celulose & 40,4 & Agricultura & 6,4 \\
Indústria petrolífera & 31,4 & Indústria têxtil & 4,3 \\
Extração mineral & 26,0 & Pecuária & 2,1 \\
Indústria metalúrgica e siderúrgica & 23,6 & Indústria eletrônica & 1,7 \\
Indústria automobilística & 12,6 & Outras atividades & 2,4 \\
\hline
\end{tabular}

\section{Quadro 3.2: Indústrias que mais causam danos ao meio ambiente}

Fonte: SANTOS; MAZZON (1995)

\footnotetext{
${ }^{16}$ SÁNCHEZ, L. E. (Epusp) Notas de aula, 1996

${ }^{17}$ De acordo com YOUNG (1992), nos Estados Unidos, em 1992, apenas 48 dos 1189 sítios contaminados constantes da lista de prioridades do programa Superfund eram minerações. Outro autor, KOVALICK (1991), estima que antigas minerações correspondem a apenas 3\% dos sítios constantes daquela lista.

${ }^{18}$ Nesta pesquisa, 842 famílias, selecionadas por área em seis regiões metropolitanas (São Paulo, Rio de Janeiro, Porto Alegre, Belo Horizonte, Salvador e Recife), foram entrevistadas pessoalmente. Um cartão com 13 tipos de indústrias foi apresentado aos entrevistados, que foram convidados a indicar os três tipos de atividade que mais agridem e danificam o meio ambiente.
} 
Um exame do Quadro 3.2, que contém resultados da pesquisa, revela, ainda, que atividades como agricultura e pecuária, usualmente mencionadas por profissionais do setor mineral como tão ou mais danosas ao meio ambiente do que a mineração, não são identificadas como tal pelos cidadãos comuns. Esta rejeição por parte da opinião pública, associada à magnitude dos impactos ambientais causados pela atividade na escala em que vem sendo praticada, resultam em fortes pressões por parte da sociedade organizada. O resultado é que, no Brasil, a mineração é a atividade econômica mais controlada pela legislação ambiental e a única citada nominalmente em vários dispositivos de proteção do meio ambiente presentes na Constituição Federal (HERRMANN, 1992).

Mas os minerais são parte essencial do mundo desenvolvido e estão presentes na vida do homem desde Paleolítico e o emprego dos metais remonta ao ano 6000 AC, quando o cobre passou a ser utilizado para a fabricação de ferramentas simples (CANADA, 1997b). Assim, como a humanidade não pode prescindir dos minerais e metais, procura meios de satisfazer suas necessidades sem agredir o meio ambiente, ou reduzindo ao nível mínimo estas agressões. A avaliação de impacto ambiental é um desses meios e terá êxito à medida que for capaz de contribuir para que a atividade seja conduzida em sintonia com o paradigma do desenvolvimento sustentável.

\subsection{A Mineração e o Desenvolvimento Sustentável}

A idéia de desenvolvimento sustentável foi expressa pela Comissão Mundial sobre o Meio Ambiente e Desenvolvimento, em 1987, em relatório intitulado Nosso Futuro Comum, também conhecido por Relatório Brundtland. Nesse documento, amplamente difundido, define-se:

"Desenvolvimento sustentável é aquele que atende às necessidades do presente sem comprometer a possibilidade de as gerações futuras atenderem a suas próprias necessidades” (COMISSÃO MUNDIAL..., 1991)

Para muitos, no entanto, a idéia de desenvolvimento sustentável é dificilmente aplicável aos minerais, visto que são recursos naturais não-renováveis. Ou seja, as reservas seriam finitas e, uma vez extraídas e consumidas, não mais poderiam suprir as necessidades das gerações futuras. Esta visão simplista, no entanto, deixa de considerar fatores como a possibilidade de descoberta de novos depósitos minerais; os avanços tecnológicos em lavra e beneficiamento, capazes de ampliar as reservas minerais; as 
várias formas de redução do consumo e a reciclagem de matérias-primas minerais. Deste modo, o primeiro desafio a ser enfrentado é o de, partindo da definição geral, formular o conceito operacional aplicável ao setor mineral. CANADA (1995) propõe a seguinte adaptação do conceito geral de desenvolvimento sustentável ao setor mineral, incluindo a metalurgia:

"O objetivo do desenvolvimento sustentável é encontrar, extrair, produzir, adicionar valor, utilizar, reutilizar e reciclar produtos minerais e metálicos da maneira mais eficiente possível, respeitando as necessidades e valores dos usuários de outros recursos e mantendo ou melhorando a qualidade do meio ambiente para as gerações presentes e futuras."

Em outras palavras, atingir a sustentabilidade ambiental na mineração significa:

- manter os estoques. É necessário pesquisar novas reservas minerais, novos métodos de prospecção e pesquisa, novas técnicas de beneficiamento, de modo a garantir, para as gerações futuras, a disponibilidade dos bens minerais por elas requeridos;

- reduzir os impactos da produção. Os trabalhos de pesquisa, lavra, beneficiamento dos minérios, assim como a desativação da minas, devem ser conduzidos de acordo com as melhores práticas ambientais, de modo a manter ou melhorar a qualidade do meio ambiente para as gerações atuais e futuras; e

- reduzir os impactos do uso. Inclui atitudes de racionalização do consumo, como a reciclagem e o reúso, tanto das próprias substâncias minerais, como dos insumos e matérias-primas empregados em sua produção.

O diagrama do ciclo de vida dos minerais e metais apresentado na Figura 3.1 sintetiza e integra as principais etapas do seu processo de produção, ilustrando a aplicação do conceito de desenvolvimento sustentável. 


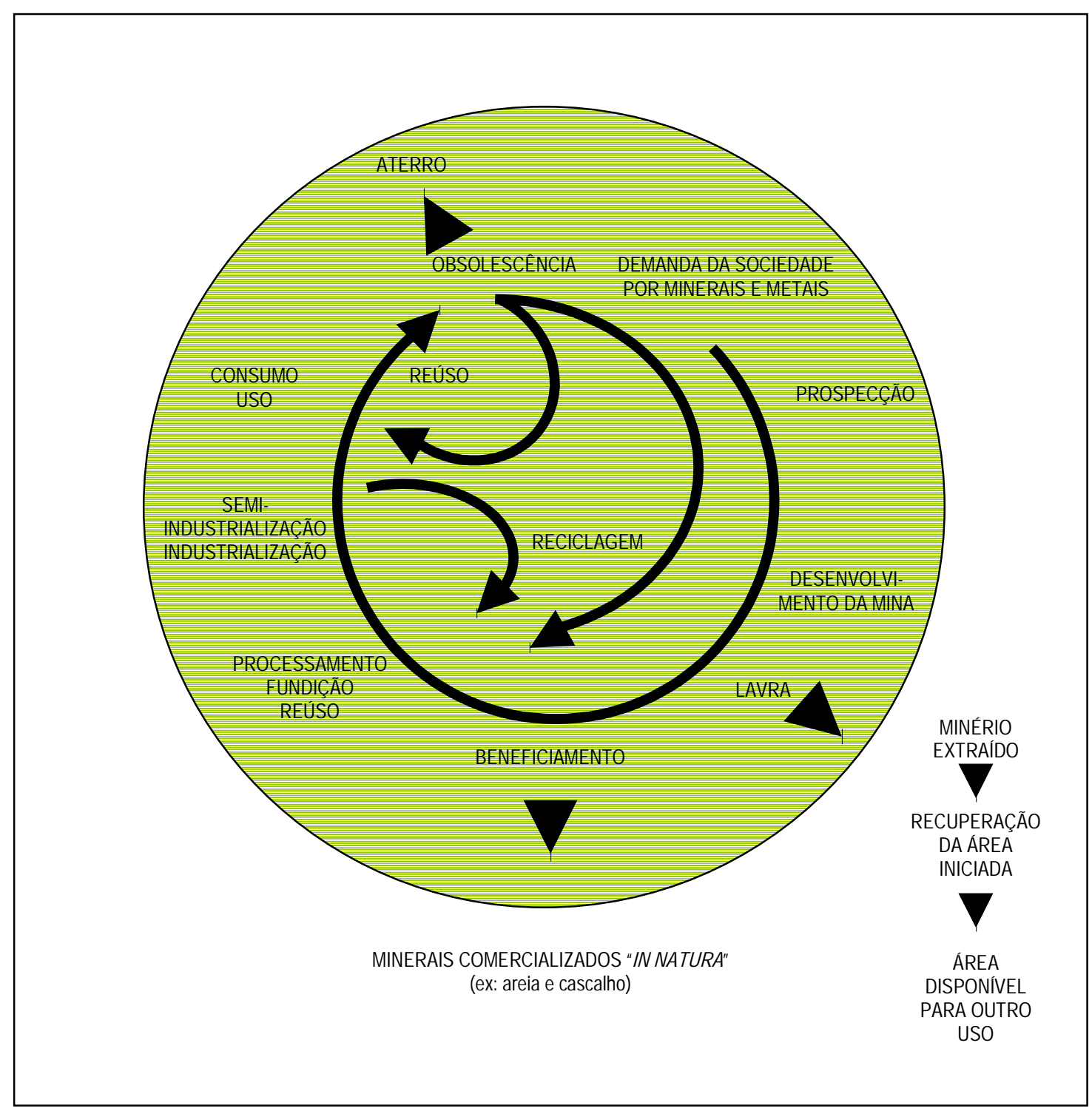

Figura 3.1: Ciclo de vida dos minerais e metais.

Fonte: CANADA (1995), traduzida.

Os procedimentos de avaliação de impacto ambiental, tal como foram concebidos e encontram-se regulamentados no Brasil, restringem-se aos aspectos diretamente vinculados à produção, no âmbito do empreendimento em análise. Regra geral, são conduzidos na etapa de elaboração do projeto, não abrangendo a pesquisa mineral, nem tampouco as etapas posteriores à industrialização. Dentro do que habitualmente se conceitua como mineração, a AIA no Brasil abrange as atividades relacionadas à lavra e ao beneficiamento, desde o desenvolvimento da mina até sua desativação e recuperação da área. 
Mesmo com esta abrangência restrita, a AIA apresenta grande potencial de contribuir para a sustentabilidade ambiental da mineração. Avaliar sua eficácia quando aplicada à mineração no Estado de São Paulo, no entanto, requer o conhecimento das características deste setor e dos impactos que pode causar no meio ambiente.

\subsection{O Setor Mineral Paulista}

Em que pese o notoriamente alto grau de imprecisão dos dados oficiais acerca das atividades de mineração no País, um primeiro olhar para o setor mineral paulista recai, inevitavelmente, no Anuário Mineral Brasileiro (AMB). Principal publicação do Departamento Nacional da Produção Mineral (DNPM), o AMB retira dos Relatórios Anuais de Lavra (RALs), cuja responsabilidade pelo preenchimento é das pessoas físicas e jurídicas titulares de concessão de lavra, manifesto de mina, grupamento mineiro e licenciamento, os dados referentes às quantidades e valores da produção mineral brasileira.

Trata-se de fonte nem sempre confiável e, para determinadas substâncias, o próprio DNPM reconhece que a cobertura por meio dos RALs é insuficiente, lançando mão de outras fontes. É o caso das substâncias Areia e Cascalho, Argilas Comuns e Plásticas e Pedras Britadas, que constituem a base da produção mineral paulista e têm seus dados de quantidade produzida e valor da produção estimados com base nos RALs e em consulta direta às associações e sindicatos de produtores, assim como em levantamentos próprios do DNPM (ANUÁRIO..., 1997).

Feitas as ressalvas, uma primeira análise dos dados oficiais revela que o Estado de São Paulo produziu, no ano de 1996, substâncias minerais no valor de 1,35 bilhões de reais, de um total nacional de 14,12 bilhões, ou seja, cerca de 9,56\%. Este desempenho colocou o Estado em terceiro lugar no cenário da produção mineral brasileira, com base em valor da produção, superado apenas pelo Rio de Janeiro e por Minas Gerais. A Tabela 3.1 ilustra este cenário.

Já nesses dados gerais, destacam-se as diferenças marcantes no perfil da produção mineral dos três principais Estados mineradores. Enquanto o Rio de Janeiro lidera apoiado nos energéticos, mais precisamente no petróleo, e Minas Gerais destacase pela produção de metálicos, em particular o ferro, em São Paulo cerca de 93,3\% da produção advém de substâncias minerais não-metálicas. CABRAL JR.; ALMEIDA 
(1999) estimam que o volume efetivamente produzido no Estado supere em cerca de 1,5 a 2 vezes o valor oficialmente registrado.

Tabela 3.1: Valor da produção mineral brasileira em 1996, por unidade da federação e classe de substância (em $R$ \$ 1.000,00)

\begin{tabular}{c|c|c|c|c|c}
\hline $\begin{array}{c}\text { UNIDADE DA } \\
\text { FEDERAÇÃO }\end{array}$ & METÁLICOS & $\begin{array}{c}\text { NÃO } \\
\text { METÁLICOS }\end{array}$ & $\begin{array}{c}\text { GEMAS E } \\
\text { DIAMANTES }\end{array}$ & $\begin{array}{c}\text { PRODUTOS } \\
\text { ENERGÉTICOS }\end{array}$ & TOTAL \\
\hline RIO DE JANEIRO & 186 & 204.766 & -- & 4.081 .683 & 4.286 .635 \\
\hline MINAS GERAIS & 1.898 .037 & 609.733 & 8.759 & --- & 2.516 .529 \\
\hline SÃO PAULO & 776 & 1.259 .051 & -- & 89.959 & 1.349 .786 \\
\hline OUTROS & 2.002 .685 & 1.665 .717 & 42.805 & 2.259 .247 & 5.970 .455 \\
\hline TOTAL & 3.901 .684 & 3.739 .267 & 51.564 & 6.430 .889 & 14.123 .405 \\
\hline
\end{tabular}

Fonte: ANUÁRIO..., 1997

Pode-se ter uma idéia melhor do perfil da produção mineral paulista pela Tabela 3.2, na qual estão relacionados as quantidades produzidas e o valor da produção de 20 grupos de substâncias não-metálicas e apenas um de metálicas.

Tabela 3.2: Quantidade e valor das substâncias minerais produzidas no Estado de São Paulo em 1996

\begin{tabular}{|c|c|c|c|}
\hline \multirow[t]{2}{*}{ SUBSTÂNCIA MINERAL } & \multicolumn{2}{|c|}{$\begin{array}{c}\text { QUANTIDADE PRODUZIDA } \\
\text { (em toneladas) }\end{array}$} & \multirow{2}{*}{$\begin{array}{c}\text { VALOR DA } \\
\text { PRODUÇÃO } \\
(\text { em R\$) }\end{array}$} \\
\hline & BRUTA & BENEFICIADA & \\
\hline & & & \\
\hline - $\quad$ Pedras britadas & (1) 33.313 .768 & 33.208 .206 & 427.549 .568 \\
\hline - $\quad$ Areia e cascalho & (1) 48.304 .819 & 393.438 & 337.521 .896 \\
\hline - Calcário & 15.350 .665 & 12.542 .853 & 154.710 .106 \\
\hline - $\quad$ Argilas comuns e plásticas & 12.755 .063 & 388.957 & 124.106 .295 \\
\hline - $\quad$ Água mineral (1) & (1) 3.355 .397 & --- & 81.689 .326 \\
\hline - $\quad$ Areia industrial & 3.438 .436 & 2.791 .966 & 42.968 .357 \\
\hline - Rocha fosfática & 3.713 .220 & 420.880 & 25.130 .952 \\
\hline - Caulim & 233.373 & 204.308 & 19.221 .076 \\
\hline - Dolomito & 536.109 & 517.495 & 16.068 .545 \\
\hline - $\quad$ Filito & 867.334 & 474.033 & 11.611 .930 \\
\hline - Granito ornamental & 11.771 & 131.005 & 6.750 .911 \\
\hline - Argilas refratárias & 167.152 & 12.054 & 3.578 .556 \\
\hline - Talco & 58.510 & 22.965 & 2.738 .347 \\
\hline - Quartzito industrial & 265.859 & 264.747 & 1.789 .690 \\
\hline - Bentonita e argilas descorantes & 23.236 & 14.919 & 1.618 .557 \\
\hline - $\quad$ Turfa & 22.663 & 12.911 & 991.177 \\
\hline - $\quad$ Bauxita refratária & 15.816 & --- & 662.681 \\
\hline - $\quad$ Feldspato & 39.196 & 2.024 & 283.558 \\
\hline - Calcita & 4.150 & 195 & 52.950 \\
\hline - Ardósia & 690 & --- & 6.396 \\
\hline MINERAIS METÁLICOS & & & 775.763 \\
\hline - Ferro & 3.699 .283 & 236.254 & 775.763 \\
\hline
\end{tabular}

Fonte: ANUÁRIO..., 1997 (1) quantidades expressas $\mathrm{em} \mathrm{m}^{3}$, (2) quantidades expressas $\mathrm{em} \mathrm{m}^{2}$ 
Além da absoluta predominância dos não-metálicos, que pode ser atribuída à combinação da aptidão de seu substrato geológico com o perfil da demanda de seu parque industrial, observa-se entre estes uma forte concentração em oito grupos de substâncias, que respondem, juntos, por 96,33\% do seu valor da produção. Em ordem decrescente de participação, são as seguintes: pedras britadas; areia e cascalho, calcário; argilas comuns e plásticas; água mineral; areia industrial; rocha fosfática e caulim. A Figura 3.2 ilustra este panorama.

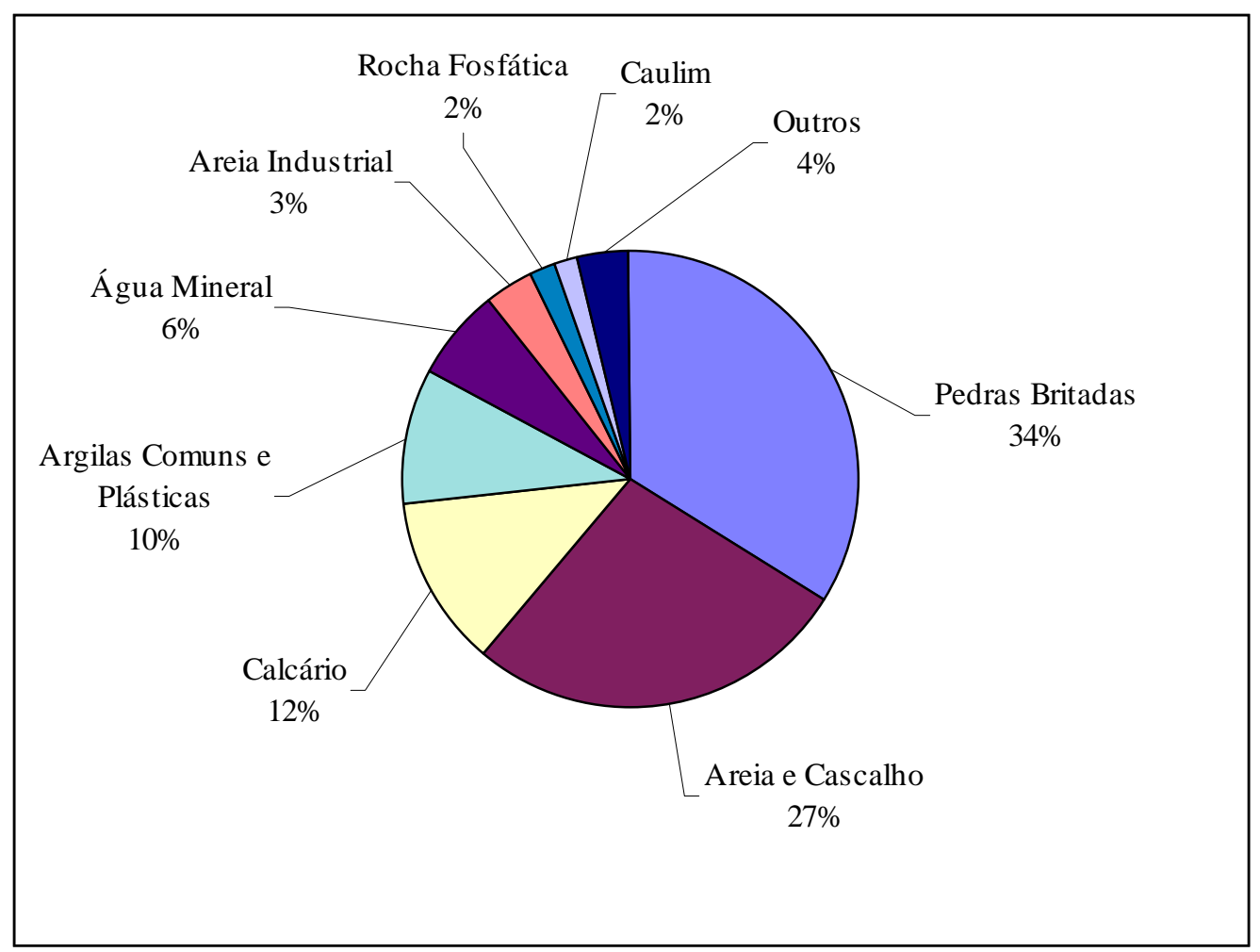

Figura 3.2: Distribuição da produção mineral paulista em 1996, em valor

De acordo com CABRAL JR.; ALMEIDA (1999), a produção mineral paulista destina-se, predominantemente, ao consumo interno de diversos setores da indústria de transformação, como o cerâmico, siderúrgico, cimenteiro e vidreiro, entre outros, além de fornecer insumos para a agricultura e construção civil.

A análise dos dados oficiais permite ainda observar outra característica marcante do setor mineral paulista. Mesmo não apresentando grandes minas, a quantidade bruta produzida no Estado em 1996 atingiu o patamar de 207 milhões de tonelada 19 de material, equiparável à produção bruta de minério de ferro de Minas Gerais no mesmo

\footnotetext{
${ }^{19}$ Para esta estimativa, foram utilizados os seguintes valores de densidade aparente: $2,15 \mathrm{t} / \mathrm{m}^{3}$ para pedras britadas, $1,95 \mathrm{t} / \mathrm{m}^{3}$ para areia e cascalho; $2,65 \mathrm{t} / \mathrm{m}^{3}$ para granito ornamental e $1,0 \mathrm{t} / \mathrm{m}^{3}$ para a água mineral.
} 
ano (203 milhões de toneladas). Lembrando-se que, para cada tonelada bruta produzida, uma certa quantidade de estéril foi movimentada e rejeitos foram gerados, pode-se perceber o alto potencial de impactos ambientais representado pela atividade. A produção mineral paulista advém de um grande número de empreendimentos sobre os quais inexistem dados precisos. Vários estudos efetuados sobre o tema, no entanto, possibilitam que se tenha uma idéia aproximada deste universo.

Em 1979, São Paulo possuía 1387 minas em atividade, distribuídas em 223 municípios, com predominância absoluta de lavras de bens minerais de uso direto ou indireto na indústria da construção civil (DIAS, 1980).

Quase uma década depois, em 1988, o número de minas foi estimado em 1363 por RUIZ; ATEM (1990). Cerca de 95,3\% destas lavras eram de argilas comuns (600); areia para construção (400); pedras britadas (150); argilas industriais (50); areia industrial (33); água mineral (25); filito (25) e feldspato (16).

Analisando a distribuição dos títulos minerários (requerimentos de pesquisa, licenças e concessões de lavra), VALVERDE (1994) observou que, em 1993, o universo do setor mineral paulista abrangia 8.000 áreas, sendo 3122 lavras ativas representadas pelos licenciamentos e concessões de lavra e 4676 expectativas de ingresso em produção, configuradas nos requerimentos de pesquisa. Estes números são indicativos da ordem de grandeza do número de minas no Estado, embora devam ser encarados com muita cautela, pois, do mesmo modo que muitas das licenças e concessões vigentes referem-se a lavras paralisadas ou abandonadas, numerosos empreendimentos operam apenas com requerimentos protocolados ou alvarás de pesquisa.

Com base em estudos recentes desenvolvidos no Instituto de Pesquisas Tecnológicas do Estado de São Paulo S.A. (IPT), MELLO et al. (1997) analisam os minerais de uso na construção civil produzidos em São Paulo, destacando, pelo volume e valor de produção atingidos, as matérias-primas empregadas "in natura" (areia, brita e rochas ornamentais), as argilas para cerâmica vermelha e as rochas carbonáticas para fabricação de cimento e cal. O Quadro 3.3 sintetiza a estimativa destes autores para o número de minas e volume de produção anual destes grupos de substâncias. 


\begin{tabular}{|l|c|c|}
\hline \multicolumn{1}{|c|}{ BEM MINERAL } & $\begin{array}{c}\text { QUANTIDADE PRODUZIDA } \\
(\mathbf{m 3 / a n o})\end{array}$ & NÚMERO DE MINAS \\
\hline \multicolumn{1}{|c|}{ Areia } & 22 milhões & 500 \\
\hline Brita & 35 milhões & 150 \\
\hline $\begin{array}{l}\text { Argila para cerâmica } \\
\text { vermelha }\end{array}$ & 15 milhões ${ }^{(*)}$ & n.d. \\
\hline $\begin{array}{l}\text { Rochas carbonáticas para } \\
\text { cimento e cal }\end{array}$ & 9,3 milhões ${ }^{(*)}$ & n.d. \\
\hline
\end{tabular}

\section{Quadro 3.3: Minerais de uso na construção civil produzidos no Estado de São Paulo.}

Fonte: MELLO et al. (1997)

Geograficamente, a distribuição das minas no território paulista subordina-se não apenas aos condicionantes geológicos, mas também às diversas formas de ocupação humana (cidades, indústrias e agricultura) que, em última análise, foram induzidas pelas características climáticas, fertilidade do solo e presença de água, entre outros fatores.

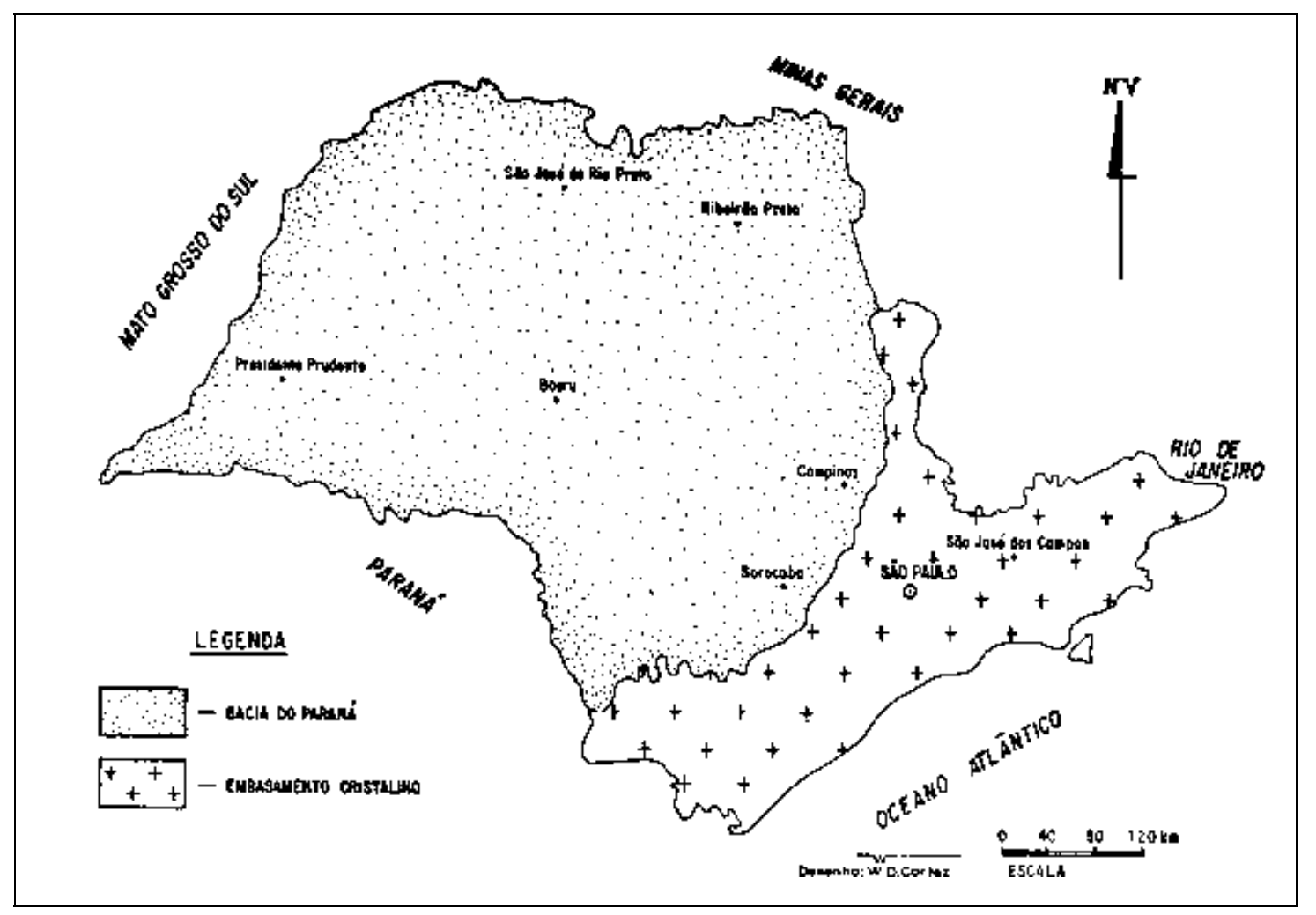

Figura 3.3: Macrocompartimentação geológica do Estado de São Paulo.

Fonte: RUIZ; ATEM (1990)

Com relação aos condicionantes geológicos, os depósitos minerais paulistas estão associados aos dois grandes domínios nos quais se insere o Estado (Figura 3.3): 
embasamento cristalino, de idade pré-cambriana, e bacias sedimentares fanerozóicas, que recobrem o embasamento (bacias do Paraná, Taubaté e São Paulo). Recobrindo indistintamente áreas sedimentares e do cristalino, ocorrem, ainda, coberturas cenozóicas, de natureza aluvionar, praial e de alteração intempérica, e jazidas de natureza ígnea, de idade mais recente (CABRAL JR.; ALMEIDA, 1999).

De acordo com estes autores, no cristalino ocorrem os principais depósitos de rochas para brita e ornamentais (leste e sul do Estado); os feldspatos, de granitos e pegmatitos (Perus, Jundiaí e Sorocaba); as minas de calcário, dolomito, calcita, talco, associadas a faixas metamórficas carbonáticas (grupos Açungui e São Roque e região de Itapeva/Sorocaba), e os filitos, quartzitos, ardósias e rochas assemelhadas, neste mesmo domínio. Nas bacias sedimentares estão as produções de areias industrial e para construção civil (Analândia, Descalvado e Bofete), de calcário corretivo (Rio Claro, Limeira e Ipeúna), de bentonitas (Vale do Paraíba), além de argila para cerâmica vermelha (faixa de Tatuí-Itu-Leme-Tambaú, Santa Gertrudes e Mogi-Guaçu).

As coberturas cenozóicas comportam jazidas de caulim (Mogi das Cruzes, Embu-Guaçu e Piedade), bauxita e argilas refratárias (Águas da Prata e Divinolândia), bem como faixas aluvionares quaternárias das quais se lavram areia, cascalho, argila comum e turfa. Incluem-se ainda neste contexto aluvionar importantes depósitos de argilas plásticas e refratárias (São Simão e Alto Tietê). Aos depósitos do Cenozóico correspondem as jazidas de fosfato e carbonatos de Jacupiranga e Ipanema e as rochas basálticas lavradas para brita na Bacia do Paraná.

Especificamente para o caso das substâncias minerais de uso direto e indireto na construção civil, MELLO et al. (1997) entendem que a combinação, em determinadas regiões, dos condicionantes geológicos favoráveis à ocorrência destas substâncias com o acelerado crescimento urbano e industrial resultaram na formação de pólos produtores regionais. Foram identificados em São Paulo cerca de três dezenas destes pólos, principalmente na porção centro-leste do Estado, compreendendo a região da Grande São Paulo, Vale do Paraíba e eixo Sorocaba - Ribeirão Preto. A Figura 3.4 ilustra esta distribuição. 


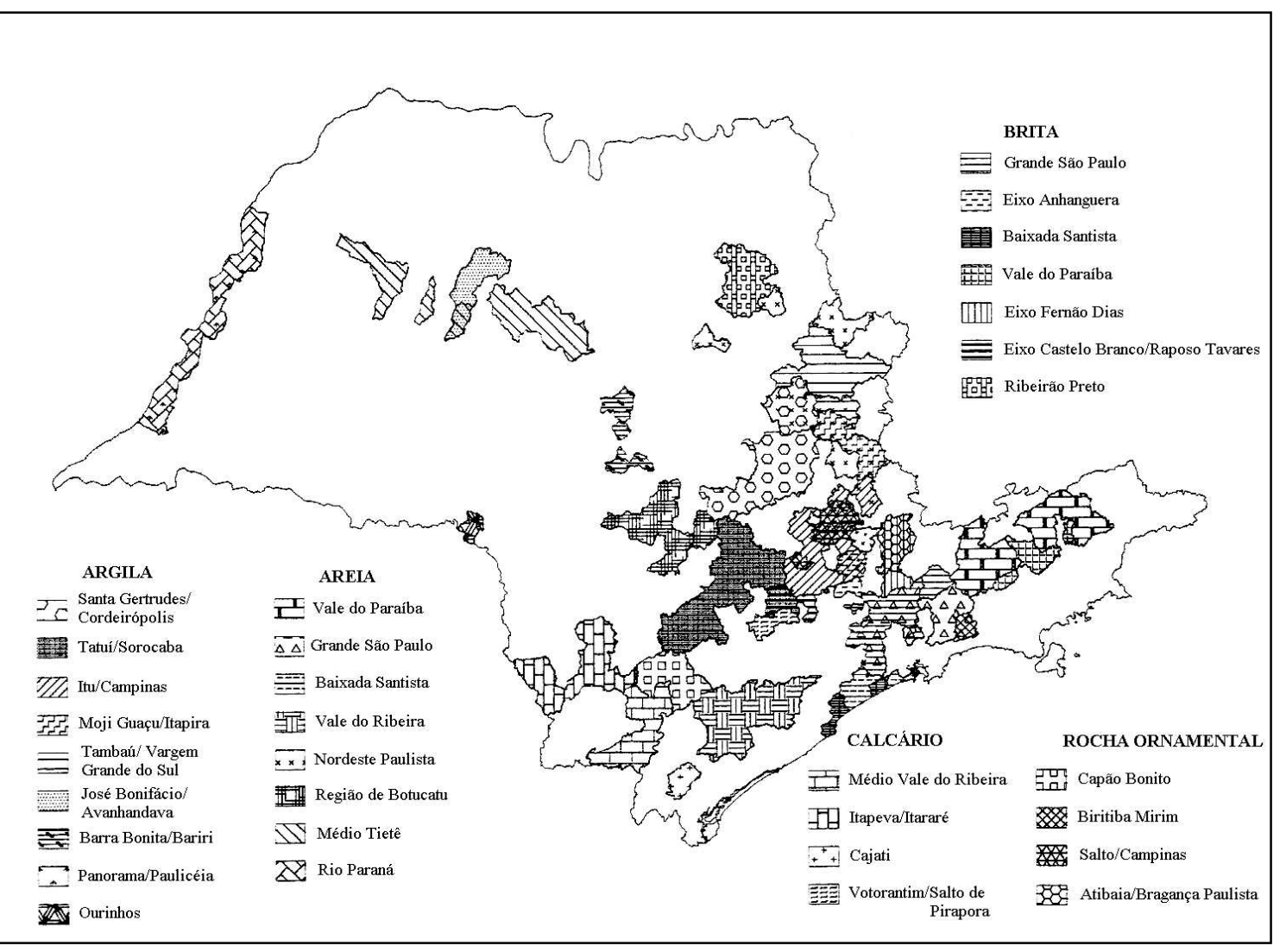

Figura 3.4: Pólos produtores de matérias-primas minerais de uso na construção civil no Estado de São Paulo

Fonte: MELLO et al. (1997)

Cada um destes pólos apresenta características próprias com relação à tecnologia de lavra e de beneficiamento, ao transporte e, conseqüentemente, aos impactos sobre o meio ambiente. Nos itens subseqüentes, são discutidos os principais impactos que a mineração pode causar nos meios físico, biótico e antrópico, destacando-se aqueles mais comuns em pequenas e médias minerações de minerais não-metálicos, agrupadas em pólos produtores e situadas próximo de centros urbanos, ou seja, situações que caracterizam o setor mineral paulista.

\subsection{Impactos sobre o Meio Físico}

Na avaliação dos impactos ambientais da mineração, é comum dividi-los de acordo com o meio afetado, ou seja, físico, biótico e antrópico. A maior parte dos efeitos da mineração, no entanto, atinge primeiramente o meio físico, sendo os impactos sobre os meios biótico e antrópico muitas vezes decorrentes dos primeiros.

\footnotetext{
${ }^{20}$ Devido a problemas na publicação, este mapa, que ilustrava o artigo em referência, não foi incluído nas atas do V Simpósio de Geologia do Sudeste. Esta figura foi reproduzida a partir de original fornecido pelos autores.
} 
Adotou-se, para este trabalho, como forma de apresentação dos impactos sobre o meio físico, a subdivisão tradicional e consagrada em impactos sobre as águas, que inclui aspectos de poluição das águas e drenagem superficial de minas; resíduos sólidos, que trata do seu gerenciamento, com ênfase nos estéreis e rejeitos; impactos sobre a atmosfera, incluindo poluição do ar, ruídos e sobrepressão acústica; e vibrações no solo causadas pelo desmonte por explosivos.

\subsubsection{Impactos sobre as águas}

São diversas as formas pelas quais a água participa das operações mineiras. Dependendo da situação, a água pode estar presente ou ser empregada:

- como meio no qual se dá a extração mineral, caso da lavra por dragagem em leito de rio, lagos ou reservatórios;

- na desagregação e transporte do minério, caso do método de desmonte hidráulico;

- nas operações de beneficiamento do minério via úmida, tais como a moagem, ciclonagem, flotação, cianetação;

- na expedição do minério, agregada a este, no caso do transporte na forma de polpa em minerodutos ou simplesmente na forma de umidade;

- na mitigação de outros impactos, como a emissão de particulados, controlada por aspersão de água;

- nas águas de chuvas, que circulam por toda a área da mina;

- em superfície e subsuperfície na área da mina e seu entorno, recebendo contribuições de águas provenientes da área do empreendimento.

Nestas ocasiões, são introduzidos poluentes nas águas que, se não forem removidos previamente ao descarte, irão contaminar os corpos d'água, causando impactos à flora, à fauna e ao meio antrópico. São considerados poluentes das águas quaisquer formas de matéria ou energia cuja presença, lançamento ou liberação possa causar danos à biota.

Os poluentes introduzidos nas águas pela mineração podem originar-se do próprio minério, de reagentes introduzidos em operações de tratamento ou ainda de superfícies desprotegidas de vegetação, como taludes nas frentes de lavra, ao longo de acessos, pilhas de minério ou estéril, pátios de manobras etc., que liberam partículas quando atingidos pelas águas pluviais. Operações auxiliares - instalações sanitárias, refeitórios, oficinas mecânicas, armazenamento de combustíveis etc. - também podem ser responsáveis pela poluição das águas em uma mina. O Quadro 3.4 relaciona os poluentes mais comuns em mineração, associando-os aos materiais, áreas ou operações 
da mina ou usina de beneficiamento que os originam e às principais medidas de controle.

Em São Paulo, o principal problema de poluição das águas é representado pelas partículas sólidas. Estas partículas são colocadas em suspensão pela ação das águas pluviais sobre as superfícies desprotegidas das minas ou sobre as pilhas de estéril ou minério armazenadas sem as devidas precauções. É possível, ainda, que estejam presentes nos efluentes do beneficiamento, muitas vezes lançados sem a necessária clarificação prévia. Poluentes orgânicos, óleos e graxas, resultantes da falta de controle de operações auxiliares, são também importante fator de poluição. A presença de álcalis nas águas das minas de rochas carbonáticas pode significar impacto em regiões onde estas minerações se concentram. Os demais poluentes relacionados no Quadro 3.4 raramente são encontrados em minas paulistas.

Estudo realizado na bacia sedimentar do rio Paraíba do Sul (Jacareí, SP) mostrou que o maior efeito impactante da atividade de mineração de areia em cava submersa sobre a qualidade da água é a elevação nos valores de turbidez, provocada pela ação conjunta do revolvimento do substrato, movimentação da coluna d'água e o retorno do rejeito particulado fino dos separadores para o corpo d'água (SHIMIZU et al., 1995). Este impacto ocorre, também, na dragagem de areia em leito de rio, com o agravante de não estar circunscrito à área de uma lagoa, afetando a biota do rio em trechos variáveis, dependendo de sua vazão e das características dos sólidos em suspensão.

As consequiências do lançamento ou liberação de um poluente em um corpo d'água dependem não somente da natureza e concentração do poluente, mas também das características do corpo d'água. No Brasil, a legislação que regula a matéria considera estes dois aspectos ao estabelecer limites de tolerância para os despejos, considerando também a qualidade e o uso preponderante dos corpos d'água.

No âmbito federal, a Resolução Conama n⿳0 20, de 18/6/86, estabelece padrões de emissão, ou seja, limites de tolerância para o lançamento de despejos em corpos d'água. Estes padrões aplicam-se apenas aos corpos d'água enquadrados nas classes 1 a 8 , definidas nesta mesma resolução segundo seus usos preponderantes. Nos mananciais subsuperficiais e nas águas enquadradas na Classe Especial, não é permitido o lançamento de poluentes, mesmo tratados. Além de atender aos padrões de emissão, os despejos somente são tolerados se não causarem a ultrapassagem dos limites estabelecidos na definição das classes de águas. 


\begin{tabular}{|c|c|c|c|}
\hline POLUENTE & ORIGEM & EFEITOS/IMPACTOS & $\begin{array}{l}\text { PRINCIPAIS } \\
\text { MEDIDAS DE } \\
\text { CONTROLE }\end{array}$ \\
\hline $\begin{array}{l}\text { Poluentes } \\
\text { orgânicos }\end{array}$ & $\begin{array}{l}\text { Instalações sanitárias } \\
\text { Refeitórios } \\
\text { Vilas residenciais } \\
\text { Detergentes utilizados } \\
\text { em oficinas mecânicas, } \\
\text { áreas de lavagem etc. } \\
\text { Reservatórios inundados } \\
\text { sem prévia remoção da } \\
\text { vegetação. }\end{array}$ & $\begin{array}{l}\text { São nutrientes de microorganismos } \\
\text { que os degradam e consomem } \\
\text { oxigênio neste processo. } \\
\text { Diminuição da capacidade de } \\
\text { autodepuração dos corpos d'água. } \\
\text { Possibilidade de eutrofização. }\end{array}$ & $\begin{array}{l}\text { Fossas sépticas } \\
\text { Estações de tratamento } \\
\text { de esgotos }\end{array}$ \\
\hline $\begin{array}{l}\text { Sais (sólidos } \\
\text { dissolvidos) }\end{array}$ & $\begin{array}{l}\text { Minério } \\
\text { Estéril } \\
\text { Rejeitos } \\
\text { Reagentes }\end{array}$ & $\begin{array}{l}\text { Nitratos e fosfatos são nutrientes } \\
\text { que, em altas concentrações, podem } \\
\text { causar eutrofização (e conseqüente } \\
\text { desoxigenação). } \\
\text { Outros sais em altas concentrações } \\
\text { podem afetar a biota. }\end{array}$ & $\begin{array}{l}\text { Correção de pH } \\
\text { Precipitação seletiva }\end{array}$ \\
\hline Cianetos & $\begin{array}{l}\text { Lixiviação de minério de } \\
\text { ouro }\end{array}$ & Alta toxicidade & \begin{tabular}{|l|} 
Oxidação \\
Degradação natural
\end{tabular} \\
\hline Metais & $\begin{array}{l}\text { Minério } \\
\text { Estéril }\end{array}$ & Toxicidade para várias espécies & $\begin{array}{l}\text { Precipitação e filtragem } \\
\text { Precipitação e flotação } \\
\text { Seqüestro em leitos }\end{array}$ \\
\hline $\begin{array}{l}\text { Partículas } \\
\text { sólidas }\end{array}$ & $\begin{array}{l}\text { Drenagem } \\
\text { Focos de erosão } \\
\text { Efluentes do } \\
\text { beneficiamento }\end{array}$ & $\begin{array}{l}\text { Aumento da carga de sedimento } \\
\text { nos cursos d'água, causando seu } \\
\text { assoreamento e favorecendo a } \\
\text { ocorrência de inundações. } \\
\text { Diminuição da luminosidade, } \\
\text { prejudicando a biota aquática. } \\
\text { Soterramento de comunidades } \\
\text { bentônicas. } \\
\text { Diminuição da produtividade } \\
\text { primária (devido à redução da } \\
\text { fotossíntese). }\end{array}$ & $\begin{array}{l}\text { Implantação de sistema } \\
\text { de drenagem para } \\
\text { minimizar a quantidade } \\
\text { de água que circula na } \\
\text { área de operação. } \\
\text { Bacia de decantação. } \\
\text { Adição de substância } \\
\text { coagulante. } \\
\text { Clarificação. }\end{array}$ \\
\hline $\begin{array}{l}\text { Óleos e } \\
\text { graxas }\end{array}$ & $\begin{array}{l}\text { Vazamentos de combus- } \\
\text { tíveis e lubrificantes } \\
\text { Oficinas mecânicas } \\
\text { Áreas de lavagem de } \\
\text { equipamentos }\end{array}$ & $\begin{array}{l}\text { Pode interferir na oxigenação de } \\
\text { águas paradas. } \\
\text { Pode cobrir as guelras dos peixes e } \\
\text { afetar outros organismos. } \\
\text { Esteticamente inconveniente. }\end{array}$ & $\begin{array}{l}\text { Caixas separadoras de } \\
\text { óleos e graxas e venda } \\
\text { para empresa } \\
\text { especializada em } \\
\text { recuperação. }\end{array}$ \\
\hline Ácidos & Minérios sulfetados & $\begin{array}{l}\text { Acidificação das águas } \\
\text { Solubilização de metais }\end{array}$ & $\begin{array}{l}\text { Neutralização } \\
\text { Pântanos artificiais }\end{array}$ \\
\hline Álcalis & $\begin{array}{l}\text { Rochas carbonáticas } \\
\text { Reagentes básicos }\end{array}$ & $\begin{array}{l}\text { Confere dureza às águas, limitando } \\
\text { usos industriais e domésticos. }\end{array}$ & Correção de pH \\
\hline $\begin{array}{l}\text { Reagentes } \\
\text { orgânicos }\end{array}$ & Flotação de minerais & $\begin{array}{l}\text { Toxicidade para várias espécies } \\
\text { Substâncias biodegradáveis } \\
\text { consomem oxigênio. }\end{array}$ & $\begin{array}{l}\text { Controle fino da usina } \\
\text { de tratamento. } \\
\text { Degradação antes do } \\
\text { lançamento. }\end{array}$ \\
\hline
\end{tabular}

\section{Quadro 3.4: Poluentes das águas mais comuns em mineração}

Fonte: SÁNCHEZ, 1995b (modificado)

No Estado de São Paulo vigoram, desde 1976, as regras estipuladas no Decreto Estadual $n^{0}$ 8468, que foram em grande parte reiteradas na Resolução Conama $n^{0}$ 20/86. Tendo em vista o princípio de que as normas estaduais somente se sobrepõem às 
federais se forem mais restritivas, para a maioria dos parâmetros vale o padrão de emissão definido na legislação federal.

De acordo com MILLER; EMERICK (1985), a indústria mineira tem de enfrentar o desafio de gerenciar com sucesso seus efluentes e devolvê-los ao ambiente em condições de evitar conseqüências indesejáveis ou perigosas. Isto pressupõe, de um lado a abordagem clássica do tratamento do efluente no final do processo, antes do descarte (end of pipe), e do outro, o esforço para minimizar as quantidades de efluentes, bem como seus níveis de contaminação.

A premissa básica é a utilização das águas em circuito fechado, ou seja, manter reservatórios na área do empreendimento para coletar as águas utilizadas nas diversas operações, tratá-las, adequando-as para o reúso na mesma ou em outra operação. Este procedimento, além de benéfico ao meio ambiente, pode ser economicamente vantajoso para o minerador. É o que sustenta FINK (1995), em seu estudo sobre reúso de águas na lavagem de equipamentos pesados em pedreiras nos Estados Unidos. No estudo desenvolvido, o custo total da lavagem de equipamentos pesados é reduzido de US \$ 4,40 (por veículo) para US\$3,01, quando se adota o reúso da água.

Outra providência, fundamental para a redução do volume das águas residuárias, é o gerenciamento das águas de drenagem das minas. Esta medida é particularmente importante no Estado de São Paulo, onde ocorre excesso de precipitação em relação à evaporação na maior parte do ano. O gerenciamento das águas pluviais inclui a adoção das seguintes medidas:

- redução da quantidade de água em circulação na área do empreendimento; possível com a implantação de sistema de drenagem que impeça ou reduza o ingresso na área de águas pluviais provenientes de áreas vizinhas, da mesma bacia de drenagem;

- redução das áreas expostas à erosão, ou seja, áreas não vegetadas. Isto implica evitar a supressão de vegetação ou ajustar o cronograma de supressão ao da operação da mina, de modo a manter as áreas desprotegidas por um tempo mínimo possível. É necessário, ainda, considerar o calendário meteorológico, uma vez que o problema se acentua na época das chuvas. Os taludes dos acessos, as pilhas de estéril e outras superfícies desprotegidas devem ser recobertas com vegetação, sempre que possível.

- implantação de sistema de coleta das águas de drenagem, constituído de canaletas estrategicamente construídas, de modo a evitar o contato das águas pluviais com material potencialmente gerador de drenagem ácida ou suscetível à erosão. As águas 
poluídas, seja por partículas sólidas, seja por acidez ou qualquer outro poluente, devem ser captadas e tratadas.

- intensificação da prática de reúso de águas.

No Estado de São Paulo, o problema de carreamento de partículas sólidas em águas de drenagem, provenientes de áreas de mineração é generalizado. A implantação e a manutenção de sistemas de drenagem são consideradas medidas dispendiosas pelos mineradores e os programas oficiais de fiscalização e controle são inadequados para cuidar do problema.

Para o tratamento propriamente dito das águas poluídas da mineração, existem técnicas consagradas, já referidas no Quadro 3.4, várias das quais não são exclusivas da mineração, mas comuns a diversos setores. É o caso das fossas sépticas e estações de tratamento de esgotos, no controle de poluentes orgânicos, e caixas separadoras de óleos e graxas.

O tratamento corretivo mais comum para águas ácidas é a adição de um reagente alcalino, como a cal, para neutralizar o ácido e precipitar os metais pesados (ENVIRONMENT CANADA, 1987). Este sistema funciona, porém os custos de implantação e operação são altos. Além disso, produz grandes volumes de resíduos sólidos (lamas), que devem ser apropriadamente dispostos. Vários outros sistemas têm sido desenvolvidos para neutralizar águas ácidas a custos menores. Este é um dos grandes desafios atuais do setor mineral, em nível mundial, uma vez que as águas ácidas provenientes de drenagem de minas, quando não são adequadamente previstas e sua formação evitada, têm de ser coletadas e tratadas por tempo indeterminado, mesmo após a desativação do empreendimento. Não existem relatos sobre a ocorrência de drenagem ácida no Estado de São Paulo.

A remoção de partículas sólidas de águas de mina, sejam provenientes da drenagem, sejam oriundas das operações de tratamento de minérios, em geral é feita em bacias de decantação ou de rejeitos. Dependendo das granulometrias e das áreas disponíveis para a construção das bacias, pode ser necessária a adição de floculantes ou o emprego de ciclones ou outro tipo de equipamento, conjugado ou não à sedimentação em bacias.

Os cuidados com a redução dos volumes de águas residuárias e com seu tratamento muitas vezes não são suficientes para garantir que os efluentes estejam em conformidade com os padrões de emissão definidos na legislação e não causem 
prejuízos aos corpos d'água nos quais são lançados. Assim, somente o monitoramento das características dos efluentes e da qualidade das águas do corpo receptor permite um gerenciamento adequado da poluição das águas.

O monitoramento dos corpos d'água receptores visa a identificar possíveis alterações introduzidas na qualidade de suas águas pelo despejo de efluentes. Assim, é necessário definir uma rede de pontos para coleta de amostra, levando em conta os pontos de despejo, a vazão de água do corpo receptor e a provável dispersão do poluente (AGUDO et al., 1988). Outro aspecto importante em um plano de monitoramento é a escolha dos parâmetros e indicadores que serão monitorados e a frequiência de coleta. Os indicadores biológicos, baseados na presença de organismos sensíveis a determinados contaminantes, em alguns casos são os únicos capazes de revelar a ocorrência de despejos tóxicos mesmo quando a água já não apresenta vestígios da substância, seja por efeito da sedimentação ou da diluição (BRANCO, 1986).

\subsubsection{Resíduos sólidos}

A Associação Brasileira de Normas Técnicas (ABNT) editou em 1987 a norma NBR 10.004 - Resíduos Sólidos (Classificação), que define os resíduos sólidos da seguinte maneira:

"São resíduos nos estados sólido e semi-sólido, que resultam das atividades da comunidade de origem: industrial, doméstica, hospitalar, comercial, agrícola, de serviços e de varrição. Ficam incluídos nesta definição os lodos provenientes de sistemas de tratamento de água, aqueles gerados em equipamentos e instalações de controle de poluição, bem como determinados líquidos cujas particularidades tornem inviável o seu lançamento na rede pública de esgotos ou corpos d'água, ou exijam, para isso soluções técnica e economicamente inviáveis em face à melhor tecnologia disponível” (ASSOCIAÇÃO..., 1987a).

No âmbito de um empreendimento minerário, enquadram-se nesta definição os seguintes materiais: estéril, rejeitos, resíduos provenientes de oficinas (sucatas, panos, estopas, embalagens e tambores contaminados), sucata em geral, resíduos domésticos provenientes de refeitórios, escritórios e almoxarifado, e resíduos provenientes de operações de tratamento de efluentes ou esgotos. Os mais importantes quanto ao volume, e também mais característicos da indústria mineira, são os rejeitos e o estéril. 
Denomina-se estéril todo o material sem valor econômico extraído para permitir a lavra do mineral útil (SÁNCHEZ, 1995c). Nas minas a céu aberto, geralmente recobrem o corpo mineralizado e têm de ser removidos para permitir sua extração. Podem ocorrer como encaixantes, intercalados ao minério ou dentro do próprio corpo mineralizado, porém com diferentes teores do mineral útil ou das impurezas. Em qualquer caso, desde que separados na etapa de lavra (lavra seletiva), estes materiais enquadram-se no conceito de estéril. São exemplos de estéril os calcários e dolomitos que, por apresentar alto teor de sílica ou impurezas, são inadequados para a fabricação de cimento. Nas pedreiras e minas de calcário de São Paulo, no entanto, a maior parte dos estéreis é constituída de solo de alteração.

Embora sem valor econômico, o estéril freqüentemente apresenta teores variáveis do mineral útil ou acessório. Nestes casos, pode tornar-se gerador de drenagem ácida quando removido. O processo é favorecido pelo aumento da porosidade que ocorre com a remoção, o que aumenta a aeração e facilita a percolação de água.

As pilhas de estéril, mesmo quando constituídas de material quimicamente inerte, são, em geral, muito suscetíveis à erosão, contribuindo significativamente para a contaminação das águas de drenagem com partículas sólidas.

Um aspecto que deve ser destacado na avaliação dos impactos ambientais relacionados ao estéril é seu volume. Dependendo da relação estéril/minério (quociente entre a quantidade de estéril a ser removida e a quantidade de minério a ser extraída), a dimensão do problema pode ser mais ou menos significativa. Esta relação pode variar desde valores insignificantes, caso dos minérios aflorantes, até índices de 20 ou 30. No caso da mina de urânio de Caldas, por exemplo, a relação estéril/minério é de 16:1, o que significa que, para cada tonelada de minério extraída, são removidas da mina 16 toneladas de estéril, que têm de ser dispostas em algum lugar (SÁNCHEZ, 1995c).

Em mineração, denominam-se rejeitos os resíduos provenientes das operações de tratamento do minério. Na maior parte das vezes, este tratamento é feito por via úmida e os rejeitos se apresentam na forma de polpas ou lamas.

É o caso das minerações de areia, que separam o mineral útil (areia) das partículas indesejáveis, constituídas principalmente de argila, silte e areia muito fina. Neste caso, as operações de tratamento do minério confundem-se, em parte, com as de lavra, uma vez que o método de desmonte hidráulico e dragagem, freqüentemente empregado, tem esta dupla finalidade. Os rejeitos, neste caso, apresentam-se na forma 
de polpa, constituída de água e partículas finas em suspensão. Embora mais raramente, os rejeitos podem apresentar-se em forma de pó ou fragmentos de rocha. É o caso do pó de pedra, proveniente da britagem de rochas e dos fragmentos de rocha ornamental, produzidos nas operações de extração dos blocos ou, posteriormente, na serragem destes.

Os rejeitos, quando na forma úmida, em geral são dispostos em bacias formadas por barragens de rejeitos, onde se promove sua decantação, muitas vezes com o auxílio de floculantes. Dependendo das quantidades envolvidas, as bacias de rejeitos podem ocupar grandes áreas que, mesmo após a sedimentação sofrem restrição de uso devido às suas características geotécnicas. Conforme a composição química dos rejeitos, dependendo da presença de determinados minerais, metais ou reagentes químicos, os rejeitos podem contribuir significativamente para a contaminação do solo e das águas subterrâneas.

As barragens e bacias de rejeitos, apesar de se destinarem à solução de um problema ambiental, a disposição dos rejeitos, na prática representam outro problema. Além de competirem pelo uso da terra, são estruturas sujeitas à ruptura, em geral executadas em terra e muito altas, podendo provocar grandes desastres ambientais, colocando em risco a população, obras e bens situados a jusante. Além disso, interferem na ecologia dos sistemas hídricos e ocupam áreas de preservação permanente. No Estado de São Paulo, existem registros de numerosos casos de ruptura de pequenas barragens associadas à mineração de areia. São acidentes de conseqüências limitadas, causados pela não-utilização de material e técnicas construtivas adequadas, ou mesmo intencionalmente, para promover o esvaziamento da bacia de decantação.

Os demais resíduos, dependendo de sua natureza e quantidades, podem também contribuir para a contaminação do solo e das águas.

No planejamento da disposição do estéril e dos rejeitos, assim como dos demais resíduos sólidos, deve-se considerar a sua natureza. De acordo com a norma NBR 10.004, são três as classes em que se dividem os resíduos sólidos:

Classe I - perigosos: são aqueles que, de acordo com suas propriedades físicas, químicas ou infecto-contagiosas, podem apresentar risco à saúde pública, ao meio ambiente, ou que apresentem características de inflamabilidade, corrosividade, reatividade, toxidade ou patogenicidade. 
Classe II - não-inertes: são aqueles que não se enquadram nas classificações de resíduos perigosos ou inertes, podendo ter propriedades de combustibilidade, biodegradabilidade, ou solubilidade em água.

Classe III - inertes: são os resíduos que, quando submetidos a contato estático ou dinâmico com a água destilada ou deionizada, à temperatura ambiente, não têm nenhum de seus constituintes solubilizados a concentrações superiores aos padrões de potabilidade da água, excetuandose os padrões de aspecto, cor, turbidez e sabor.

Os problemas ambientais relativos à contaminação do solo e das águas superficiais e subterrâneas situadas na área de influência do empreendimento, são agravados quando os resíduos se enquadram nas classes I e II. Os resíduos da classe III podem, no entanto, causar diversos impactos nas águas superficiais e na atmosfera pela liberação de partículas sólidas.

Parte das medidas para a minimização dos impactos provocados pela disposição dos resíduos sólidos já foi discutida no item anterior, Impactos sobre as águas. No item seguinte, Impactos sobre a atmosfera, será discutida a questão das pilhas de estéril e bacias de rejeitos como fonte de emissão de material particulado para o ar.

Também se aplica neste caso a premissa de iniciar o controle dos efeitos pela minimização da geração do resíduo. Isto corresponde ao emprego de melhores técnicas de lavra e beneficiamento, como a busca de alternativas de utilização do material. $\mathrm{O}$ estéril e os rejeitos podem, muitas vezes, ser utilizados na recuperação das áreas mineradas, dentro do próprio empreendimento ou em obras civis necessárias à operação da mina, ou ainda, ser comercializados para usos diversos. Perseguir o objetivo do aproveitamento integral da jazida, além de contribuir para a conservação e melhoria do meio ambiente, pode ser vantajoso do ponto de vista econômico.

Quando sua utilização não é possível, o estéril deve ser disposto em pilhas, adotando-se métodos construtivos adequados para garantir sua estabilidade. As pilhas devem ser recobertas por vegetação e possuir sistema de drenagem (ALMEIDA et al., 1992). No caso de estéril quimicamente não-inerte, é necessária a coleta das águas de drenagem que percolam através da pilha e seu tratamento para reúso ou descarte.

Nas minerações do Estado de São Paulo ocorrem numerosos problemas relacionados à disposição de estéreis e rejeitos. As minas de calcário para corretivo de solo, na região de Rio Claro, por exemplo, apresentam capeamento espesso e são 
lavradas a céu aberto. Este material, removido e disposto sem os devidos cuidados, causa degradação de extensas áreas, inviabilizadas para outros usos.

HOSSEIN et al. (1993) identificam três técnicas tradicionalmente adotadas pela indústria mineira para dispor seus resíduos: (I) disposição subaquática em lagos; (II) disposição subterrânea (backfilling); e (III) disposição em superfície. A disposição subaquática em ambientes naturais não é aceita atualmente devido aos impactos que causa na biota aquática. A disposição subterrânea deve ser adotada sempre que possível, pois atende simultaneamente a dois propósitos: dispor os resíduos e recuperar a área minerada. Presta-se, no entanto apenas a situações específicas e somente podem ser utilizados resíduos com características apropriadas, em geral requer material de granulometria mais grosseira. A disposição em superfície, em bacias de rejeitos, é a forma mais usual de disposição de rejeitos provenientes das operações de tratamento de minérios por via úmida, embora também apresente problemas.

De acordo com (HOSSEIN (op. cit.), bacias de rejeito requerem (I) rígido controle das operações de tratamento, (II) bom sistema de distribuição de fluxo, e (III) segregação das águas de drenagem de áreas contaminadas. Apresentam, ainda, a desvantagem de ocupar grandes superfícies. Este último problema ocorre em São Paulo, onde a disputa pelo uso da terra adquire grande importância, uma vez que a proximidade aos centros urbanos aumenta o valor das áreas e as superfícies geradas pelo preenchimento de bacias de rejeito nem sempre apresentam as propriedades geotécnicas requeridas para suportar construções com finalidade industrial ou habitacional.

Grande parte dos rejeitos do beneficiamento de minerais é constituída de areias e rochas cominuídas que podem ser utilizados como material de construção. Na África do Sul, os rejeitos mais grosseiros da concentração do ouro têm sido utilizados para produzir asfalto, blocos de cimento e material de aterro, entre outros usos (BLIGHT; WILLIAMSON, 1994).

Quanto às frações mais finas, o problema é mais complexo, pois a sedimentação é mais difícil. McPHEAT et al. (1977) estudaram o problema dos rejeitos da mineração de areia para construção na região metropolitana de Adelaide, Austrália, e observaram que as lamas são conduzidas às bacias de decantação com $2 \%$ a $10 \%$ de sólidos e um alto teor de argila. A sedimentação é lenta e atinge densidade máxima de $30 \%$ de sólidos. Para uma produção de 2 milhões de toneladas anuais de areia lavada, são geradas cerca de 200 mil toneladas de lamas, que ocupam um volume de 
aproximadamente $500 \mathrm{mil} \mathrm{m}^{3}$, equivalente à cerca de 50\% do volume "in situ" de areia minerada. As soluções preconizadas para o problema da disposição deste material incluem o aproveitamento das lamas como matéria-prima, o desaguamento com auxílio de equipamentos apropriados e a secagem em leito fluidizado.

\subsubsection{Impactos sobre a atmosfera}

A mineração causa impactos na qualidade do ar pela introdução de poluentes e ondas sonoras audíveis e não-audíveis.

\section{Poluição do ar}

A poluição atmosférica pode ter causas naturais ou ser provocada pela atividade humana. No primeiro grupo enquadram-se as erupções vulcânicas, as tempestades de areia e os incêndios florestais provocados por raios, entre outros eventos. As atividades do homem, por seu turno, emitem uma ampla variedade de poluentes atmosféricos, freqüientemente associados ao processo de combustão.

Os poluentes atmosféricos podem ser classificados em dois grandes grupos: gases, que podem ser orgânicos ou inorgânicos; e aerossóis, também referidos como aerodispersóides ou particulados dispersos, que consistem em partículas sólidas ou líquidas em suspensão no ar.

De acordo com DOWN; STOCKS (1977), a mineração produz, em certa medida, todos os cinco poluentes atmosféricos considerados mais importantes monóxido de carbono $(\mathrm{CO})$, hidrocarbonetos $(\mathrm{HC})$, óxidos de nitrogênio $\left(\mathrm{NO}_{\mathrm{x})}\right.$ e de enxofre $\left(\mathrm{SO}_{\mathrm{x}}\right)$ e material particulado - , porém o grupo mais importante e mais amplamente disseminado em todos os tipos de empreendimento é o do material particulado. O processamento secundário de produtos minerais, como a metalurgia ou a fabricação de cimento, no entanto, figura entre os principais setores responsáveis pela poluição industrial do ar.

Dentre os poluentes gasosos associados à atividade de mineração, destacam-se os óxidos de carbono $\left(\mathrm{CO}\right.$ e $\left.\mathrm{CO}_{2}\right)$, o dióxido de enxofre $\left(\mathrm{SO}_{2}\right)$, os óxidos de nitrogênio $\left(\mathrm{NO}_{\mathrm{x}}\right)$, o metano $\left(\mathrm{CH}_{4}\right)$ e o radônio $(\mathrm{Rn})$.

Os dois primeiros são produtos de queima incompleta de combustíveis fósseis, sendo o CO um gás incolor e inodoro capaz de afetar a oxigenação do sangue e, dependendo do grau de exposição, causar dor de cabeça, vertigens, náuseas, desmaios e 
até morte. DOWN; STOCKS (op. cit.) referem-se ao CO como a principal causa de acidentes fatais entre trabalhadores em minas de carvão. Seus efeitos, no entanto, raramente ultrapassam os limites do empreendimento. $\mathrm{O} \mathrm{CO}_{2}$, por outro lado, não foi incluído por estes autores, que consideram seus efeitos imediatos desprezíveis, ou mesmo benéficos, uma vez que favorecem o crescimento das plantas. Atualmente, o $\mathrm{CO}_{2}$, juntamente com o metano $\left(\mathrm{CH}_{4}\right)$, são reconhecidos como os principais responsáveis pelo efeito estufa.

O dióxido de enxofre, produzido pela queima de combustíveis contendo enxofre, pela detonação de explosivos e na metalurgia de sulfetos, tem poder altamente destrutivo, podendo atingir o ser humano e outros organismos, além de provocar danos em diversos materiais, em áreas muitas vezes distantes do ponto de emissão. $\mathrm{Na}$ atmosfera, o $\mathrm{SO}_{2}$ reage com oxigênio, formando $\mathrm{SO}_{3}$, que é altamente higroscópico e combina com a umidade do ar, gerando ácido sulfúrico. Esta reação é catalisada pela presença de partículas de ferro ou manganês, entre outras. O ácido sulfúrico precipita-se na forma de chuva ácida e pode causar danos em áreas muito distantes do ponto de emissão. DOWN; STOCKS (op. cit.) relatam o caso de uma fundição de ferro aberta em 1896, cujas emissões de $\mathrm{SO}_{2}$ chegaram ao pico de 9300 t/mês, causando a destruição de praticamente todas as coníferas em um raio de $19 \mathrm{~km}$ e o retardamento do crescimento de algumas espécies a até $63 \mathrm{~km}$ de distância.

Os óxidos de nitrogênio $\left(\mathrm{NO}_{\mathrm{x}}\right)$ são produtos característicos de processos de combustão em altas temperaturas. São gerados na detonação de explosivos e nos motores a diesel. Quando lançados na atmosfera, assim como os hidrocarbonetos (compostos químicos de hidrogênio e carbono), reagem com oxigênio na presença de luz solar, dando origem aos oxidantes fotoquímicos. Estas substâncias, dentre as quais o ozônio é a principal e por isso utilizado como indicador, podem afetar a saúde, causando principalmente problemas respiratórios, além de danificar o solo e a vegetação. $\mathrm{O}$ controle dos óxidos de hidrogênio e dos hidrocarbonetos na atmosfera é necessário mais em razão de seus produtos do que por seus efeitos diretos. No caso dos $\mathrm{NO}_{\mathrm{x}}$, somente o $\mathrm{NO}_{2}$ é preocupante por si mesmo, podendo causar problemas respiratórios.

O gás metano $\left(\mathrm{CH}_{4}\right)$ e o radônio $(\mathrm{Rn})$ são poluentes associados especificamente à mineração de carvão e urânio (ou outros minerais radioativos), respectivamente, que não ocorrem no Estado de São Paulo. 
No grupo dos aerodispersóides, considerado o mais importante e disseminado em todos os tipos de empreendimentos mineiros, enquadram-se as poeiras, partículas sólidas resultantes dos vários processos de desintegração das rochas; a névoa, partículas líquidas produzidas por ruptura de líquidos; os fumos e as neblinas, provenientes da condensação de vapores; a fumaça, constituída de partículas muito finas, sólidas ou líquidas; e a fuligem, resultado da mistura de partículas muito finas de carvão com fumaça e gases de combustão. (ESTON, 1994)

Os efeitos provocados pelos particulados na atmosfera variam com o tamanho das partículas, que determina seu comportamento. Com base no diâmetro das partículas, DOWN; STOCKS (1977) classificam os particulados em três grupos:

1) partículas com diâmetro inferior a $0,1 \mu \mathrm{m}$, usualmente resultantes de processos de combustão, apresentam movimento browniano e nunca sedimentam, embora possam coagular por colisão e ter assim seu tamanho aumentado;

2) partículas com diâmetros entre 0,1 e 1,0 $\mathrm{mm}$, formadas pela condensação de vapores, não são afetadas pelo movimento browniano, mas seu tempo de sedimentação é da ordem de meses; e

3) partículas com diâmetros entre 1,0 e $200 \mu \mathrm{m}$, formadas pela desintegração de sólidos ou por aglomeração, apresentam velocidade de sedimentação terminal constante, regida pela lei de Newton, no caso das mais grosseiras (entre 150 e $200 \mu \mathrm{m}$ ); e pela

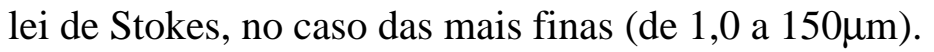

Do ponto de vista de saúde humana, definem-se ainda as partículas inaláveis, ou seja, aquelas capazes de passar pelas vias nasais e chegar aos pulmões. DERÍSIO (1992) considera partículas inaláveis aquelas com diâmetro equivalente inferior a $10 \mu \mathrm{m}$, embora DOWN; STOCKS (1977) situem este limite em $5 \mu \mathrm{m}$, sustentando que partículas de diâmetro superior a $5 \mu \mathrm{m}$ são interceptadas no nariz. Dentro deste grupo, ALMEIDA (1999) destaca as partículas com diâmetro inferior a 2,5 $\mu \mathrm{m}$, denominadas respiráveis, que podem depositar-se no aparelho respiratório humano.

Além dos efeitos sobre a saúde humana e de outros seres vivos, a presença de particulados no ar acarreta redução da visibilidade; e sua sedimentação, dependendo da natureza do material, pode causar danos em edificações e contaminação de solos, vegetação e água. Mesmo material tido como não-tóxico, como o calcário, pode 
provocar alteração na diversidade de espécies em uma floresta, pelas mudanças que provoca nas características do solo.

Com relação às fontes de poluição atmosférica, uma classificação adequada ao gerenciamento da poluição do ar na mineração as divide em pontuais e não-pontuais. São ditas pontuais as fontes que lançam os poluentes através de uma chaminé ou conduto projetado para direcionar ou controlar seu fluxo e podem ser subdivididas em fixas e móveis. As demais são não-pontuais e podem ser lineares, como as estradas, ou superficiais, como pátios, pilhas, frente de lavra etc.

As quantidades de poluentes emitidas por uma fonte podem ser estimadas a partir de fatores de emissão, que representam a relação entre a massa provável de poluente emitida e a quantidade de material manuseado ou processado. De acordo com SÁNCHEZ (1995d), estudos desenvolvidos pela agência federal de proteção ambiental dos Estados Unidos, a Environmental Protection Agency (EPA), têm sido amplamente utilizados como a fonte mais confiável de estimativas de fatores de emissão de poluentes atmosféricos em atividades industriais.

Para a estimativa da emissão de particulados em fontes não-pontuais como estradas (pavimentadas ou não) e pilhas (formação, retomada e erosão eólica) existem métodos de cálculo desenvolvidos a partir de estudos empíricos.

Tão importante quanto o conhecimento dos poluentes e de suas fontes, o gerenciamento da poluição do ar causada por um empreendimento requer informações sobre as condições meteorológicas atuantes na área e no seu entorno. Delas depende a colocação dos poluentes em suspensão, sua dispersão e deposição em locais às vezes muito distantes. Os processos de transporte de poluentes são, em geral, muito complexos, envolvendo grande diversidade de fatores. Assim, os métodos empregados para a previsão do impacto de emissões para a atmosfera na qualidade do ar em diversos locais baseiam-se em modelos matemáticos.

Para reduzir os impactos da poluição atmosférica de um empreendimento adotam-se basicamente dois tipos de medidas: as destinadas a reduzir as quantidades emitidas e as que impedem que os poluentes emitidos atinjam os pontos de interesse, como áreas habitadas ou ecossistemas sensíveis.

Para o caso das emissões não-pontuais, KINSEY; COWHERD JR. (1992) classificam as medidas de controle em dois tipos básicos: preventivas e de captura e remoção. O primeiro tipo inclui as medidas destinadas a evitar a formação de 
particulados ou seu lançamento na atmosfera. Os principais tipos de medidas preventivas aplicáveis à mineração são: enclausuramento total ou parcial da fonte; umidificação de superfícies, com ou sem adição de aglomerantes; e estabilização de superfícies não pavimentadas, que inclui a aplicação de produtos químicos, compactação ou revestimento das superfícies com materiais de reduzido potencial de emissão ou mesmo implantação de coberturas vegetais; minimização do desmatamento e ajuste do seu cronograma de modo a reduzir ao mínimo as áreas desprotegidas.

As medidas de captura e remoção tratam dos particulados quando estes já estão incorporados na atmosfera. Incluem os vários sistemas de captura e coleta de poluentes, como coifas e filtros, e a aspersão de água, com ou sem adição de aglomerantes, sobre a pluma de particulados, para provocar a aglomeração e sedimentação das partículas em suspensão; e a implantação de barreiras vegetais capazes de absorver parcialmente gases como $\mathrm{NO}_{2}$ e $\mathrm{SO}_{2}$ e reter parte do material particulado (ESTON, 1994).

O Quadro 3.5 resume as principais fontes de particulados na mineração e respectivas técnicas de redução das emissões.

\begin{tabular}{|c|c|}
\hline ATIVIDADE OU FONTE & MEDIDA DE CONTROLE \\
\hline Perfuração & $\begin{array}{l}\text { Injeção de água (com ou sem adição de surfactantes) } \\
\text { VLE + ECP (ciclone ou filtro de manga) }\end{array}$ \\
\hline Detonação & $\begin{array}{l}\text { Detonação em condições favoráveis de dispersão } \\
\text { Aspersão de água sobre a bancada }\end{array}$ \\
\hline Carregamento & Aspersão de água \\
\hline Transporte interno & $\begin{array}{l}\text { Aspersão de água nas pistas } \\
\text { Revestimento das pistas } \\
\text { Controle do tráfego (limite de velocidade) }\end{array}$ \\
\hline $\begin{array}{l}\text { Britagem } \\
\text { Peneiramento }\end{array}$ & $\begin{array}{l}\text { Enclausuramento total ou parcial } \\
\text { Aspersão de água } \\
\text { VLE + ECP }\end{array}$ \\
\hline Estocagem em pilhas & $\begin{array}{l}\text { Redução da altura de descarga } \\
\text { Aspersão de água no ponto de descarga } \\
\text { Cobertura com lona ou vegetação } \\
\text { Barreiras de vento } \\
\text { Enclausuramento (silos, galpões) } \\
\text { Aspersão de água com surfactantes }\end{array}$ \\
\hline Silos & VLE + ECP \\
\hline Correias transportadoras & $\begin{array}{l}\text { Enclausuramento } \\
\text { Aspersão de água } \\
\text { VLE + ECP }\end{array}$ \\
\hline Transporte externo & $\begin{array}{l}\text { Enclausuramento da carga } \\
\text { Cobertura com lona } \\
\text { Aspersão de substância aglomerante }\end{array}$ \\
\hline Secagem e calcinação & VLE + ECP (filtro eletrostático, lavador de gases) \\
\hline
\end{tabular}

Quadro 3.5: Principais fontes de particulados em mineração e seu controle Fonte: SÁNCHEZ (1995d), ENVIRONMENTAL PROTECTION AGENCY (1977) e YOCOM (1992).

${ }^{21}$ VLE: ventilação local exaustora; ECP: equipamento de controle de poluição. 
Referência obrigatória para o gerenciamento da qualidade do ar em um empreendimento mineiro ou para a avaliação prévia dos impactos ambientais a ele associados são os padrões de emissão e de qualidade do ar aplicáveis ao local e ao tipo de atividade em estudo. No Brasil, em nível federal, os principais dispositivos legais que regulam a matéria são:

- Resolução Conama n⿳ 5/89, que institui o Programa Nacional de Controle do Ar (Pronar), estabelecendo estratégias para o controle, preservação e recuperação da qualidade do ar;

- Resolução Conama n⿳0 3/90, que fixa padrões primários e secundários de qualidade do ar para os diversos tipos de poluentes e define os métodos de amostragem e análise destes poluentes. Padrões primários correspondem às concentrações de poluentes que, ultrapassadas, poderão afetar a saúde da população. Padrões secundários são as concentrações de poluentes abaixo das quais se prevê o mínimo efeito adverso sobre o bem-estar da população, assim como o mínimo dano à fauna, à flora, aos materiais e ao meio ambiente em geral.

- Resolução Conama $\mathrm{n}^{\mathrm{o}}$ 8/90, que estabelece limites máximos de emissão de poluentes do ar (partículas totais, $\mathrm{SO}_{2}$ e densidade colorimétrica) para processos de combustão externa em fontes novas fixas de poluição, tais como: caldeiras, geradores de vapor, centrais para a geração de energia elétrica, fornos, fornalhas, estufas e secadores para a geração e uso de energia térmica, incineradores e gaseificadores. Os limites máximos de emissão variam conforme o porte da fonte e sua localização.

No âmbito estadual em São Paulo, vigora o Decreto Estadual nº 8468/76, que estabelece padrões de qualidade do ar para um número restrito de poluentes e padrões de emissão para fumaça e particulados provenientes de determinadas fontes, instaladas em áreas críticas de poluição relacionadas no Decreto.

De modo geral, observa-se que a legislação somente define padrões de emissão para um número restrito de fontes. Por outro lado, o emprego dos padrões de qualidade do ar para o controle pontual de fontes de poluição esbarra em dificuldades, uma vez que, dada a complexidade dos processos de transporte de poluentes no ar, não é simples determinar a origem de um poluente atmosférico. Deste modo, os padrões de qualidade estabelecidos para o ar são utilizados principalmente para orientar a formulação de planos regionais de controle ou planos de ação de emergência em episódios críticos de 
poluição do ar (GOUVÊA, 1999). Resta, enfim, para o controle da poluição do ar, além dos poucos padrões de emissão, pouco aplicáveis à mineração, a verificação dos efeitos deletérios que os lançamentos causam no meio ambiente.

Mesmo com estas restrições, a avaliação dos impactos de uma mineração sobre a qualidade do ar em diversos pontos de interesse pode ser obtida com a implementação de um programa de monitoramento que possibilite comparações entre as situações anterior e posterior à instalação do empreendimento. De acordo com ESTON (1994), são os seguintes os principais métodos de medição da qualidade do ar aplicáveis à mineração: geoquímico, que mede o acúmulo de metais no solo ou nos vegetais; deposição de poeira e poeira sedimentável; amostradores de grande volume, que medem a concentração de partículas em suspensão no ar; e biológico, que utiliza indicadores biológicos como determinados musgos que possuem alta capacidade de troca catiônica e de retenção de metais presentes no ar.

Para se conhecer a influência real do empreendimento sobre a qualidade do ar, é fundamental que sejam conhecidos os níveis básicos de qualidade nos diversos pontos de interesse antes de sua implantação. Mesmo nos casos em que estes dados não são disponíveis, os resultados dos programas de monitoramento podem ser utilizados para verificação da eficiência de medidas de controle.

A concepção de um plano de monitoramento parte da identificação das fontes e poluentes de interesse, dos locais que deverão ser monitorados, o que depende das condições atmosféricas e das características das áreas potencialmente afetadas, dos métodos e equipamentos adequados e da frequiência e duração das medidas. Trata-se de um conjunto complexo de parâmetros, de difícil conhecimento. Com relação à periodicidade de amostragem, a EPA fixou frequiências mínimas para alguns parâmetros como $\mathrm{SO}_{2}$, poeira em suspensão, $\mathrm{CO}, \mathrm{O}_{3}$ e NO . (DERÍSIO, 1992).

\section{Ruídos e sobrepressão acústica}

Ruídos são sons indesejáveis. Sons são variações de pressão detectáveis pelo ouvido humano. A audibilidade depende basicamente da frequiência da variação de pressão e é diferente de indivíduo para indivíduo. Situa-se, em geral, entre 20 e 20.000 Hz. Dentro deste espectro, o ouvido humano detecta melhor os sons de freqüência entre 1000 e $4000 \mathrm{~Hz}$. 
Além da freqüência, outro parâmetro físico que caracteriza o som é a amplitude da onda sonora, relacionada à pressão sonora. $\mathrm{O}$ ouvido humano apresenta um largo espectro de sensibilidade à pressão sonora (de $20 \mu \mathrm{Pa}$ a $20 \mathrm{~Pa}$ ). A escala logarítmica, utilizada para medir o nível de pressão sonora (NPS), facilita a expressão desta grandeza.

Na escala logarítmica, os níveis de pressão sonora, expressos em decibéis (dB), não podem ser somados aritmeticamente. Por exemplo, dois sons de $60 \mathrm{~dB}$ somados resultam em $63 \mathrm{~dB}$, ou seja, a adição de $3 \mathrm{~dB}$ representa a duplicação do nível de pressão sonora. $\mathrm{O}$ uso da escala logarítmica, embora seja conveniente por permitir que os valores de pressão sonora de interesse estejam dentro de um domínio numérico adequado, pode induzir a erros intuitivos na avaliação da magnitude dos níveis de ruído. É o caso de situações nas quais o padrão ambiental é superado em $3 \mathrm{~dB}$, de $65 \mathrm{~dB}$ para $68 \mathrm{~dB}$, por exemplo. À primeira vista a diferença é inferior a 5\%, mas, na verdade, tratase da duplicação do nível de pressão sonora admissível.

A medida da intensidade do som é ainda afetada por compensações, em geral já embutidas nos equipamentos de medição, que corrigem o nível de pressão sonora de acordo com a frequiência da onda, considerando a variação da sensibilidade auditiva. Existem três curvas de compensação, denominadas A, B e C, sendo que a curva A é a que melhor representa a resposta do ouvido humano.

O sopro de ar ou sobrepressão acústica, associado à detonação de cargas explosivas, assim como o som e o ruído, é uma onda de pressão atmosférica. Grande parte da energia transmitida por estas ondas, no entanto, situa-se na faixa de frequiência não-audível. A intensidade do sopro de ar também é medida em decibéis, porém não se efetua, neste caso, a compensação por meio das curvas A, B ou C. A medida é expressa em decibéis lineares.

O Quadro 3.6 ilustra com alguns exemplos típicos os níveis de pressão sonora produzidos por equipamentos de mineração e outras fontes. 


\begin{tabular}{|l|c|}
\hline \multicolumn{1}{|c|}{ FONTES DE RUÍDO E EXEMPLOS TÍPICOS } & NPS [em dB(A)] \\
\hline Limiar da dor & 120 \\
\hline Concerto de rock & 110 \\
\hline Perfuratriz a ar comprimido (1m) & 110 \\
\hline Caminhão fora-de-estrada (cabina do motorista) & 74 a 109 \\
\hline Trator (cabina do operador) & 84 a 107 \\
\hline Área de pedreira (vários pontos ao ar livre) & 88 a 102 \\
\hline Carregadeira frontal (cabina do operador) & 83 a 101 \\
\hline Britador de mandíbulas (operador) & 90 a 100 \\
\hline Usina de flotação (dentro do galpão) & 63 a 91 \\
\hline Moinho de bolas (operador) & até 100 \\
\hline Campainha de despertador (1 m) & 80 \\
\hline Conversação normal & 60 \\
\hline Casa rural & 40 \\
\hline Queda de uma folha & 10 \\
\hline Limiar de audibilidade & 0 \\
\hline
\end{tabular}

\section{Quadro 3.6: Níveis típicos de ruído}

Fonte: DOWN; STOCKS (1977)

Os problemas causados por ruídos excessivos têm se agravado nos últimos tempos, especialmente em áreas urbanas. A exposição a altos níveis de ruído pode causar desde alterações passageiras até graves defeitos irreversíveis. ASTETE (1979) classifica os efeitos do ruído sobre o sistema auditivo em três tipos:

1) mudança temporária no limiar de audição, ou surdez temporária, que ocorre após a exposição do indivíduo a ruído intenso, mesmo por curto período de tempo;

2) surdez permanente, causada pela exposição repetida, durante longos períodos, a ruídos de intensidade excessiva; e

3) trauma acústico, perda auditiva repentina causada por exposição a ruído intenso de curta duração, como explosões.

Além dos efeitos sobre o aparelho auditivo, o ruído excessivo pode provocar uma série de desordens físicas, mentais e emocionais, como irritabilidade, fadiga, distúrbios do sono, interferência na comunicação oral, queda do nível de atenção etc.

O sopro de ar provocado pela detonação de cargas explosivas pode causar danos a estruturas, que vão desde a quebra de vidraças ao aparecimento de rachaduras no revestimento e até na própria alvenaria. De acordo com DOWN; STOCKS (1977), é consenso universal que a quebra de vidraças precede qualquer outro tipo de dano estrutural. 
Ondas de sobrepressão de intensidade muito inferior à necessária para quebrar vidraças podem, no entanto, causar incômodo às pessoas. Esta sensação, no caso do sopro de ar, é influenciada pelo caráter intermitente das detonações e pela rejeição que a maioria dos indivíduos tem em relação a atividades que envolvem explosivos.

O gerenciamento dos ruídos e do sopro de ar, como no caso de outros poluentes, tem como referência básica os limites legalmente admissíveis. Os dispositivos legais vigentes no Brasil consideram os ruídos em ambientes internos e externos. No primeiro caso, a preocupação é com a saúde ocupacional e a competência é federal, a cargo do Ministério do Trabalho. Neste âmbito, existe a Portaria no 3.214 , do Ministério do Trabalho, de 18.06.78, que aprova normas regulamentadoras relativas à segurança e medicina do trabalho.

No que se refere ao meio externo ou aos níveis de ruído ambiental, SÁNCHEZ (1995e) reporta como primeira regulamentação federal brasileira a Portaria Minter n⿳o 92, de 19.06.80, segundo a qual são considerados prejudiciais à saúde, à segurança e ao sossego público, os sons e ruídos que ultrapassarem em $10 \mathrm{~dB}(\mathrm{~A})$ ou mais o ruído de fundo existente no ambiente externo ao recinto onde se originam, ou ultrapassarem $70 \mathrm{~dB}(\mathrm{~A})$ durante o dia e $60 \mathrm{~dB}(\mathrm{~A})$ durante a noite, no referido ambiente externo, independentemente do ruído de fundo.

Mais restritiva do que a Portaria $n^{0}$ 92, a Resolução Conama $n^{0} 1$, editada em 08.03.90, confere força de lei à norma editada pela ABNT em 1987, a NBR n⿳0 10.151 Avaliação do ruído em áreas habitadas visando ao conforto da comunidade. Os níveis máximos de ruído tolerados, relacionados no Quadro 3.7, variam com o período (diurno ou noturno) e com os diferentes tipos de zona.

\begin{tabular}{|l|c|c|}
\hline \multirow{2}{*}{ USO PREDOMINANTE DO SOLO } & \multicolumn{2}{|c|}{ NÍVEL MÁXIMO (em dB (A)) } \\
\cline { 2 - 3 } & DIA & NOITE \\
\hline Zona residencial; zona hospitalar & 45 & 40 \\
\hline Zona residencial urbana & 55 & 50 \\
\hline Centro da cidade (negócios, comércio, administração etc.) & 65 & 60 \\
\hline Área predominantemente industrial & 70 & 65 \\
\hline
\end{tabular}

\section{Quadro 3.7: Níveis máximos de ruído}

Fonte: ASSOCIAÇÃO... (1987b)

Com relação aos níveis admissíveis para o sopro de ar, a principal referência no País é a norma NBR n⿳ำ 9653, “Guia para avaliação dos efeitos provocados pelo uso de 
explosivos em minerações em áreas urbanas", de dezembro de 1989, que estabelece o valor máximo de $134 \mathrm{~dB}$ (linear pico) para o nível de pressão sonora no ponto receptor (ASSOCIAÇÃO..., 1989). A Cetesb, em São Paulo, adota critérios fixados na norma D7.013, de abril de 1992, intitulada "Mineração por explosivos - procedimento", que limita em 128 dB (linear pico) o nível de pressão sonora medido no receptor. Considerando que esta norma, mesmo tendo sido elaborada em 1992, ainda não foi homologada pela diretoria da Cetesb, conclui-se que não existe, até o momento, instrumento com força de lei disciplinando a matéria.

DOWN; STOCKS (1977) identificam três categorias principais de fontes de ruído na mineração: unidades fixas, unidades móveis e transporte externo. As unidades fixas incluem britadores, moinhos, peneiras, esteiras, silos, equipamentos para tratamento de minérios, ventiladores, geradores elétricos etc. Localizam-se, em geral, em áreas internas da mina e são freqüentemente enclausuradas. As unidades móveis são, em geral, associadas às operações de perfuração, detonação de explosivos, carregamento e transporte interno. $\mathrm{O}$ transporte externo refere-se não somente à remessa do produto da mina, mas também ao suprimento de materiais e movimentação de pessoal. A maior parte deste transporte utiliza caminhões, que são fonte importante de ruído e incômodo para as comunidades do entorno da mina.

A intensidade dos problemas de ruído causados por um empreendimento minerário depende não somente dos níveis de pressão sonora gerados nas fontes fixas e móveis, que por sua vez variam com o tipo de equipamento e volume de produção, mas também da distância entre os pontos de geração e recepção de ruídos e das condições de atenuação existentes no caminho. Conseqüentemente, as medidas mitigadoras aplicáveis a este tipo de poluição baseiam-se em três enfoques principais: redução do ruído gerado na fonte, isolamento da fonte e incremento da atenuação ou absorção do ruído no trajeto entre a fonte e o receptor.

O primeiro grupo de medidas inclui desde a escolha de equipamentos mais silenciosos na fase de projeto ou substituição dos mais ruidosos quando o problema já está instalado, até o emprego de silenciadores ou a correta lubrificação das máquinas e a manutenção e regulagem de motores. Com medidas deste tipo, chega-se a alcançar reduções entre 7 e 15 dB(A) nos níveis de pressão sonora (DOWN; STOCKS, 1977).

$\mathrm{O}$ enclausuramento pode ser aplicado diretamente sobre uma fonte fixa, ou a fonte de ruído excessivo pode ser instalada em recinto fechado. As reduções nos níveis 
de ruído obtidas com esta medida variam de cerca de 3 a $5 \mathrm{~dB}(\mathrm{~A})$, obtidos com a aplicação de revestimento absorvente em superfícies refletoras, até 45 a $50 \mathrm{~dB}(\mathrm{~A})$, obtidos com o emparedamento da fonte com tijolos de $22 \mathrm{~cm}$ (DOWN; STOCKS, op cit.).

Dentre as medidas de atenuação, a primeira baseia-se em uma importante característica da propagação das ondas sonoras. O nível de pressão sonora decai com a distância entre a fonte e o receptor. Deste modo, as fontes fixas devem ser localizadas o mais distante possível das áreas mais sensíveis ao ruído, ou seja, dos limites do empreendimento, das áreas habitadas ou utilizadas para a criação de animais, geralmente sensíveis ao ruído. Este cuidado aplica-se tanto às fontes fixas, como ao traçado dos acessos.

Outro aspecto fundamental relativo à propagação dos ruídos é a influência das condições atmosféricas. Em relação à direção predominante dos ventos, as fonte fixas não devem ser instaladas a montante de áreas externas sensíveis.

Influi, ainda, na propagação das ondas sonoras, a natureza das superfícies sólidas existentes no trajeto. Um piso absorvente, como a grama, chega a reduzir o nível de pressão sonora de 1 a $3 \mathrm{~dB}(\mathrm{~A})$ a cada $30 \mathrm{~m}$ (DOWN; STOCKS, op cit.).

Finalmente, podem-se construir barreiras entre a fonte e o receptor. Estas barreiras podem ser muros, pilhas de estéril, árvores e barreiras acústicas especialmente projetadas. O posicionamento destas barreiras deve ser cuidadosamente estudado, pois a eficiência da medida depende em grande parte deste fator. Barreiras colocadas mais próximas à fonte são, de modo geral, mais eficientes. As barreiras, além de servir para impedir a propagação dos ruídos em determinadas direções, prestam-se a outras finalidades como medida de segurança, redução de impacto visual, solução para a disposição de estéril etc. Embora comumente citadas como medida mitigadora de ruídos, as barreiras vegetais, se não forem adequadamente projetadas (altura, espessura, folhagem etc.), são pouco eficientes para este propósito.

As ondas de pressão associadas à detonação de cargas explosivas têm sua origem em uma área bem definida da mina, a frente de lavra. O sopro de ar é gerado pela liberação para a atmosfera de gases provenientes de explosivos malconfinados e, principalmente, de cordéis detonantes expostos, assim como pela transmissão para o ar da onda de choque propagada no maciço rochoso. 
As medidas recomendadas para a redução do sopro de ar na fonte consistem, basicamente, na execução de um desmonte eficiente, com adequado confinamento dos explosivos, e projetado de modo que a energia produzida na explosão seja aproveitada ao máximo para a fragmentação da rocha e seu lançamento sobre a praça de lavra.

Adicionalmente, considerando que determinados fenômenos meteorológicos, como a inversão térmica e os ventos, podem propiciar a propagação destas ondas de pressão, recomenda-se não realizar detonações de cargas explosivas em condições meteorológicas adversas.

A previsão dos problemas relacionados à poluição sonora e sopro de ar envolve uma grande diversidade de variáveis. São necessárias a identificação das principais fontes e dos receptores externos mais sensíveis; a previsão dos níveis de pressão sonora nos pontos de emissão e de recepção, envolvendo a análise das condições de propagação, atenuação e absorção; e a definição das medidas mitigadoras necessárias e previsão de sua eficiência.

Estes estudos, dependendo do caso, podem requerer o emprego de modelos matemáticos e até a realização de simulações. Mesmo assim, seus resultados irão conter um significativo grau de incerteza. Assim, o plano de monitoramento constitui um instrumento fundamental para o gerenciamento deste tipo de poluição, uma vez que permite avaliar o acerto das previsões, medir a eficiência das medidas mitigadoras e subsidiar a concepção e adoção de medidas complementares.

Particularmente em São Paulo, onde os empreendimentos mineiros situam-se, freqüentemente, muito próximos de centros urbanos, os problemas relacionados ao ruído e ao sopro de ar contribuem de maneira significativa para a instalação e manutenção dos conflitos entre a empresa e as comunidades vizinhas. Estes conflitos, uma vez instalados, são de difícil solução, requerendo a adoção de medidas que vão além da adequação da atividade aos padrões ambientais recomendáveis tecnicamente ou exigíveis legalmente. Daí a importância de uma adequada previsão e monitoramento do problema, permitindo à empresa antecipar-se aos eventuais reclamos da comunidade.

\subsubsection{Vibrações no solo causadas pelo desmonte por explosivos}

No desmonte de rochas por explosivos, cargas explosivas são detonadas no interior do maciço com o objetivo de fragmentar a rocha, lançando-a sobre a bancada em forma de pilha. A fragmentação é necessária para adequar a granulometria da rocha 
às máquinas e equipamentos utilizados nas operações de transporte e britagem. Nem sempre este objetivo é atingido no desmonte do maciço, sendo necessárias, nestes casos, operações de desmonte secundário dos blocos de tamanho superior ao desejado.

Parte da energia liberada na detonação dos explosivos é transmitida para o ambiente, provocando abalos no solo semelhantes aos produzidos por terremotos. A perturbação propaga-se sob a forma de ondas dos seguintes tipos:

1. longitudinais, também denominadas ondas de compressão, primárias ou simplesmente ondas P. Estas ondas provocam, nas partículas do solo, movimentos sucessivos para frente e para trás, ao longo do eixo de avanço da onda, o que corresponde a efeitos de compressão e tração na rocha;

2. transversais ou de cisalhamento, secundárias ou ondas $S$, formadas a partir da reflexão ou refração de ondas $\mathrm{P}$, provocam nas partículas do solo movimentos em um plano perpendicular à direção de propagação das ondas $\mathrm{P}$; e

3. ondas de superfície, dentre as quais se destacam as ondas Rayleigh ou ondas $\mathrm{R}$ como as mais importantes, são geradas quando as ondas $\mathrm{P}$ e $\mathrm{S}$ atingem a interface entre o solo e o ar. O movimento induzido pelas ondas $\mathrm{R}$ nas partículas de solo é elíptico e retrógrado, situando-se em um plano perpendicular à superfície e paralelo à direção de propagação das ondas $\mathrm{P}$.

As frentes de onda propagam-se a velocidades diferentes, dependendo do tipo de rocha e do tipo de onda. As ondas $\mathrm{P}$ são as mais rápidas e atingem velocidades da ordem de 3000 a $6000 \mathrm{~m} / \mathrm{s}$ em formações de rocha dura (DOWN; STOCKS, 1977). Estas ondas são muito úteis na prospecção geofísica, que procura determinar as características do meio atravessado a partir da velocidade de propagação da onda de choque.

Do ponto de vista ambiental, o interesse recai sobre o movimento provocado pela passagem das ondas nos seres e nas estruturas atingidas. Estuda-se, então, o movimento de uma partícula imaginária, solidária ao meio atravessado. Este movimento assemelha-se ao de um objeto flutuando na água que, quando atingido por ondas provocadas pelo vento ou outra fonte de perturbação, move-se em torno de um ponto fixo. O objeto não se desloca com a onda, apenas executa um movimento vibratório em torno do ponto de repouso inicial.

Vários autores (CHAPOT, 1981; LANGEFORS e KIHLSTRÖN, 1978 apud SÁNCHEZ, 1995f) sustentam que a vibração das partículas pode ser representada 
matematicamente por equações do movimento senoidal. Trata-se de uma hipótese simplificadora que, no entanto, não introduz erros significativos.

Os parâmetros fundamentais que caracterizam o movimento vibratório das partículas do solo são: deslocamento, velocidade, aceleração e frequiência. Numerosos estudos foram realizados em vários países buscando correlacionar os parâmetros do movimento vibratório com seus efeitos nas estruturas. Resultados destes estudos, compilados por KONYA (1995), são apresentados no Quadro 3.8.

\begin{tabular}{|l|l|l|}
\hline \multicolumn{1}{|c|}{ AUTOR / ANO } & \multicolumn{1}{|c|}{ PARÂMETRO } & \multicolumn{1}{c|}{ LIMITES } \\
\hline $\begin{array}{l}\text { THOENEN; WINDES / } \\
1942\end{array}$ & Aceleração (a) & $\begin{array}{l}\text { Zona segura: } \mathrm{a}<0,1 \mathrm{~g} \\
\text { Zona de atenção: } 0,1<\mathrm{a}<1,0 \mathrm{~g} \\
\text { Zona de dano: } \mathrm{a}>1,0 \mathrm{~g}\end{array}$ \\
\hline CRANDELL, F. J. / 1949 & $\begin{array}{l}\text { Coeficiente de energia } \\
\text { (Energy Ratio, ER)* }\end{array}$ & $\begin{array}{l}\text { Zona segura: ER }<3 \\
\text { Zona de atenção: } 3<\mathrm{ER}<6 \\
\text { Zona de dano: ER }>6\end{array}$ \\
\hline $\begin{array}{l}\text { LANGEFORS, } \\
\text { KIHLSTERBERG e }\end{array}$ & Velocidade (v) & $\begin{array}{l}\text { Sem dano: } \mathrm{v}<71 \mathrm{~mm} / \mathrm{s} \\
\text { Pequenas fissuras: } 71<\mathrm{v}<109 \mathrm{~mm} / \mathrm{s} \\
\text { Fissuras: } 109<\mathrm{v}<160 \mathrm{~mm} / \mathrm{s} \\
\text { Fissuras intensas: } 160<\mathrm{v}<231 \mathrm{~mm} / \mathrm{s}\end{array}$ \\
\hline $\begin{array}{l}\text { NICHOLS, JOHNSON e } \\
\text { DUVALL / 1971 }\end{array}$ & Velocidade (v) & $\begin{array}{l}\text { Zona segura: } \mathrm{v}<50,8 \mathrm{~mm} / \mathrm{s} \\
\text { Zona de dano: } \mathrm{v}>50,8 \mathrm{~mm} / \mathrm{s}\end{array}$ \\
\hline
\end{tabular}

(*) ER tem a dimensão da velocidade; $\mathrm{ER}=1$ é equivalente à velocidade de partícula igual a 48,3 $\mathrm{mm} / \mathrm{s}$.

\section{Quadro 3.8: Limites de vibração de partículas}

Fonte: KONYA, 1995

De acordo com SÁNCHEZ (1995h), trabalhos realizados em diversos países da Europa, no Canadá e na Austrália chegaram a valores seguros para a velocidade máxima de vibração da partícula variando entre $10 \mathrm{~mm} / \mathrm{s}$ e $20 \mathrm{~mm} / \mathrm{s}$.

Em 1980, o U.S. Bureau of Mines (USBM) publicou o Boletim $n^{0} 8507$ (SISKIND et al., 1980), no qual considerava que a ressonância das estruturas em situações de baixa freqüência de vibração do solo resultava em aumento do deslocamento e da tração. O nível seguro de vibrações, definido como o que não acarreta fissuras ou outros danos em residências, foi definido de acordo com o tipo de estrutura e do nível de freqüência, conforme Quadro 3.9.

\begin{tabular}{|c|c|c|}
\hline TIPO DE & \multicolumn{2}{|c|}{ VELOCIDADE MÁXIMA DE VIBRAÇÃO DE PARTÍCULA } \\
\cline { 2 - 3 } ESTRUTURA & BAIXA FREQÜÊENCIA $(<40 \mathrm{~Hz})$ & ALTA FREQÜÊ̂NCIA $(>40 \mathrm{~Hz})$ \\
\hline Residências modernas & $19,05 \mathrm{~mm} / \mathrm{s}$ & $50,8 \mathrm{~mm} / \mathrm{s}$ \\
\hline Residências antigas & $12,07 \mathrm{~mm} / \mathrm{s}$ & $50,8 \mathrm{~mm} / \mathrm{s}$ \\
\hline
\end{tabular}

Quadro 3.9 Nível seguro de vibrações para estruturas residenciais

Fonte: SISKIND et al.(1980), modificado 
No Brasil, a norma técnica NBR 9653 (ASSOCIAÇÃO..., 1989), especificamente orientada para a prevenção de danos em construções civis recentes, bem projetadas e construídas, e em bom estado de conservação, estabelece que a velocidade de vibração de partícula resultante não deve ultrapassar o valor de $15 \mathrm{~mm} / \mathrm{s}$. Conforme destaca ESTON (1998), esta norma não aborda o aspecto incômodo, não considera faixas de frequiência, importantes para a análise de freqüências naturais das edificações, e apresenta erros conceituais, como a definição de velocidade resultante a partir de suas componentes cartesianas.

De acordo com KONYA (1995), com o avanço da tecnologia de utilização de explosivos, a maioria das operações de desmonte pode ser conduzida com segurança e os danos às estruturas causados por vibrações são perfeitamente evitáveis. No que concerne ao incômodo causado pelas vibrações nos seres humanos, entretanto, o problema é muito mais complexo, uma vez que envolve também fatores subjetivos. Este aspecto é particularmente importante no caso de minerações em áreas urbanas.

Estudos pioneiros publicados em 1931 (REIHER; MEISTER, 1931 apud DOWN; STOCKS, 1977) revelam que a resposta humana às vibrações é complexa, depende de vários fatores, entre os quais a freqüência e a amplitude, e que a sensibilidade é maior quando a vibração é paralela ao eixo do corpo, isto é, vibrações verticais quando o indivíduo está em pé e horizontais quando deitado.

A maior parte dos estudos conduzidos a respeito da resposta humana às vibrações refere-se a vibrações de duração relativamente longa quando comparadas às causadas pelo desmonte de rochas por explosivos. Além disso, estas vibrações geralmente são acompanhadas pelo sopro de ar, que causa o efeito desagradável do ruído, além de provocar trepidação em vidraças. Conseqüentemente, os critérios obtidos a partir do estudo de vibrações de longa duração e não acompanhadas dos efeitos do sopro de ar são dificilmente aplicáveis nas situações de mineração.

Nas conclusões de seu detalhado estudo, SISKIND et al. (1980) afirmam que os fatores limitantes para os níveis de vibrações causadas por desmonte decorrem fundamentalmente das reações humanas, uma vez que em níveis muito inferiores aos necessários para causar danos, as vibrações já são percebidas pelas pessoas. A reação humana depende não só do nível das vibrações, mas também de sua duração. Estes autores concluíram que velocidades de partícula de até $12,7 \mathrm{~mm} / \mathrm{s}$, decorrentes de 
operações típicas de desmonte de rochas (duração de 1 segundo), podem ser consideradas toleráveis por $95 \%$ das pessoas.

O significado deste número pode ser confrontado com os resultados de pesquisa, na qual ESTON (1998) constatou, com base em 58 medidas captadas ao longo de um ano em um ponto situado a cerca de 150 a $250 \mathrm{~m}^{2}$ do local da detonação de uma pedreira, que nenhuma velocidade de partícula superou $12 \mathrm{~mm} / \mathrm{s}$, cerca de $88 \%$ ficaram abaixo de 7,5 mm/s e $97 \%$ abaixo de $10 \mathrm{~mm} / \mathrm{s}$. Apesar de operar abaixo dos limites fixados pela norma NBR no 9653, a pedreira em questão, situada no Estado de São Paulo, ultrapassava os limites fixados pela Cetesb.

Com efeito, no Estado de São Paulo, o estabelecimento de limites de tolerância para as vibrações no solo causadas pelo desmonte por explosivos tem sido objeto de controvérsias entre os órgãos de fiscalização e o setor produtor. Enquanto este último adota como referência a norma $\mathrm{ABNT}, \mathrm{NBR}^{\mathrm{0}}$ 9653, que objetiva a segurança das estruturas, a Cetesb baseia-se em critérios próprios, muito mais restritivos.

Estes critérios constam da norma D7013, de abril de 1992, intitulada "Mineração por Explosivos - procedimento", que preconiza que a velocidade de vibração de partícula medida na componente vertical não pode ser superior a $3 \mathrm{~mm} / \mathrm{s}$. Nos casos em que não se dispuser de equipamento capaz de registrar a componente vertical, o limite passa a ser de $4,2 \mathrm{~mm} / \mathrm{s}$ para a velocidade resultante.

Apesar de concluída em abril de 1992, esta norma ainda não foi homologada pela diretoria da Cetesb. Ainda assim, os limites de tolerância vêm sendo utilizados na fiscalização das operações de desmonte, principalmente quando o órgão recebe reclamações da população do entorno. Nesses casos, o órgão ambiental vale-se de dispositivo previsto no Decreto $\mathrm{n}^{\mathrm{o}}$ 8468/76 (Art. $3^{\mathrm{o}}$, V), que considera poluente, entre outros, qualquer forma de energia lançada no meio ambiente que o torne ou possa tornálo "inconveniente ao bem-estar público; danoso aos materiais, à fauna e à flora; prejudicial à segurança, ao uso e gozo da propriedade, bem como às atividades da comunidade".

A necessidade de manter as operações de desmonte por explosivos sob rígido controle; prever os níveis de vibração que irão atingir as estruturas e a população do entorno e mantê-los abaixo dos níveis de tolerância admissíveis, principalmente no que

\footnotetext{
${ }^{22}$ A variação da distância reflete o deslocamento da bancada com o avanço da lavra, já que o ponto de captação não variou.
} 
se refere ao incômodo, requer, além de um estudo prévio detalhado do fenômeno de geração e propagação destas ondas de choque, um cuidadoso programa de monitoramento das vibrações.

$\mathrm{Na}$ fase de planejamento considera-se que os dois principais fatores que afetam o nível de vibrações são a carga de explosivos por espera e a distância entre o local da detonação e o local da medição. O nível de vibrações cresce com a carga explosiva e decresce com a distância.

Vários estudos foram desenvolvidos buscando estabelecer uma relação entre a velocidade de partícula (V), a carga de explosivo por espera (w) e a distância ao ponto receptor (d). KONYA (1995) apresenta o resultado de dois deles, o do US Bureau of Mines (USBM) e o da Dupont. Em unidades métricas (velocidade em milímetros por segundo (mm/s), distância em metros (m) e carga de explosivos em quilogramas $(\mathrm{kg})$ ), as equações são as seguintes:

$$
\begin{gathered}
\mathrm{V}=714,4[\sqrt{ }(\mathrm{d} / \mathrm{w})]^{-1,6}, \text { para o USBM; e } \\
\mathrm{V}=1143[\sqrt{ }(\mathrm{d} / \mathrm{w})]^{-1,6}, \text { para a Dupont. }
\end{gathered}
$$

Estas equações permitem estimar a velocidade de partícula que será induzida pela detonação de uma carga explosiva em um ponto situado a uma dada distância do local da explosão. A velocidade de partícula calculada utilizando-se a fórmula da Dupont é $60 \%$ maior do que a calculada com a do USBM.

Outro parâmetro utilizado para prever os efeitos do desmonte por explosivos é a distância escalonada (Ds), definida pela relação entre a distância e a raiz quadrada da carga de explosivos (Ds $=\mathrm{d} / \sqrt{\mathrm{w}}$ ). Quanto maior for a distância escalonada, menor será a velocidade de vibração no local considerado.

De acordo com KONYA (op cit), o U. S. Bureau of Mines propõe o valor de 22,7 como limite de segurança, ou seja, situações nas quais a distância escalonada for superior a este valor são consideradas seguras. Trata-se de um limite conservador, uma vez que corresponde à velocidade de partícula de $4,83 \mathrm{~mm} / \mathrm{s}$. Ainda assim, alguns órgãos reguladores nos Estados Unidos (EUA) adotam limite de segurança ainda maior (Ds>27,5).

Qualquer que seja o parâmetro ou equação empírica utilizada, entretanto, o resultado será apenas indicativo. Previsões mais acuradas somente poderão ser obtidas com a realização de estudos específicos na área onde se pretende implantar o empreendimento ou em áreas que apresentem condições geológicas similares. 
A redução dos níveis de vibração de partículas pode ser obtida atuando-se sobre os dois principais fatores que determinam sua intensidade: a carga de explosivos e a distância. A maneira mais usual de se reduzir a carga de explosivos é o uso de retardos, ou seja, uma grande carga de explosivos é detonada como uma série de pequenas cargas, em intervalos de tempo da ordem de milissegundos. Este procedimento faz com que frentes de onda geradas em diferentes detonações separadas por retardos atinjam o ponto receptor em momentos distintos, já que a velocidade de propagação da onda é a mesma. O resultado são distintas vibrações de menor intensidade. Em casos extremos, pode-se efetuar a detonação furo a furo.

Quanto à distância ao ponto receptor, é mais difícil reduzí-la, uma vez que a localização da frente de lavra é determinada pelas características do depósito em explotação. Em projetos novos deve-se evitar a construção de estruturas em áreas sujeitas a riscos e, sempre que possível, recomenda-se adquirir terrenos situados no entorno da futura mina, de modo a evitar sua ocupação, muitas vezes induzida pelo próprio empreendimento.

Especialistas em desmonte de rochas por explosivos recomendam, ainda, vários cuidados para reduzir os níveis de vibração de partículas. De acordo com artigo elaborado por técnicos do Instituto de Pesquisas Tecnológicas do Estado de São Paulo S. A. (IPT), esses cuidados incluem a seleção do tipo de explosivo, a disposição dos furos, a definição das cargas e retardos e a geometria das bancadas, entre outros (INSTITUTO DE PESQUISAS ..., 1985).

Os problemas associados ao desmonte de rochas por explosivos têm estimulado o desenvolvimento de métodos alternativos de fragmentação de rochas. Um destes métodos, conhecido como "drop ball", vem se disseminando em pedreiras nas operações de desmonte secundário (IRAMINA, 1996). O sistema consiste em soltar uma esfera de aço sobre os blocos de rocha obtidos no desmonte do maciço, quebrandoos. Além da redução do incômodo causado pelo desmonte secundário (fogacho), o método apresenta outras vantagens, como a eliminação de interrupções nas operações da mina causadas pelos procedimentos de segurança.

Além deste método, o uso de rompedores hidráulicos acoplados a escavadeiras vem sendo aprovado em pedreiras na Região Metropolitana de São Paulo. Estimativas dos distribuidores apontam que atualmente já existem mais de 130 equipamentos do 
gênero operando no País em pedreiras, cimenteiras, siderúrgicas e construtoras (ANÔNIMO, 1997a).

Equipamento semelhante, porém de maior porte, pode ser utilizado para substituir o uso de explosivos no desmonte primário. É o caso de pedreira do interior de São Paulo que adotou recentemente este sistema e considera os resultados animadores após 350 horas de operação. A eliminação das interrupções e a possibilidade de recuperar frentes de lavra improdutivas devido à presença de explosivos não detonados são citadas como vantagens adicionais à redução dos problemas ambientais e conflitos decorrentes (ANÔNIMO, 1997b). Trata-se, ainda, de pedreira de pequeno porte e experiência pioneira, mas pode estar indicando um caminho ou uma tendência na solução dos conflitos gerados pelas operações de desmonte de rochas por explosivos com as populações instaladas no entorno.

Nos empreendimentos em que o desmonte é feito por explosivos, que constituem a quase totalidade das minerações de rocha dura do Estado de São Paulo, no entanto, é imprescindível a condução de um programa de monitoramento das vibrações. SÁNCHEZ (1995f) salienta que, assim como em qualquer monitoramento ambiental, neste caso deve-se manter um registro de todas as medidas efetuadas, contendo no mínimo as seguintes informações:

- esquema da bancada e sua localização na mina;

- quantidade de explosivo e seqüência de detonação;

- tipo de explosivo, iniciador e demais acessórios utilizados;

- hora da detonação e condições atmosféricas;

- local de captação e distância;

- tipo de sismógrafo empregado;

- resultados obtidos; e

- operador do sismógrafo e técnico responsável pela detonação.

As medidas devem ser tomadas em diversos locais, tendo em vista que o movimento de propagação das ondas de choque varia conforme as condições geológicas do meio. A análise dos registros de medida deverá possibilitar o conhecimento das leis de propagação do maciço. Associando este conhecimento às eventuais reclamações feitas pela comunidade, ter-se-á um indicador local da resposta humana às vibrações. Estas informações constituem valiosos subsídios para alterações no plano de fogo ou mesmo no método de desmonte primário ou secundário. 


\subsection{Impactos sobre o Ecossistema}

"Os vegetais, animais e microorganismos que vivem numa região e constituem uma comunidade biológica estão ligados entre si por uma intrincada rede de relações que inclui o ambiente físico em que existem estes organismos. Estes componentes físicos e biológicos interdependentes formam o que os biólogos designam com o nome de ecossistema” (EHRLICH \& EHRLICH, 1974 apud MOREIRA, 1992). Nesta intrincada rede de relações, cada elemento desempenha um papel e participa ativamente da manutenção do equilíbrio do ecossistema.

Um exemplo desta distribuição de papéis é a organização da chamada cadeia alimentar, cujo funcionamento envolve tanto os organismos - vivos ou mortos, vegetais e animais-, como os componentes abióticos do ecossistema - solo, água, nutrientes e energia. Da complexidade das relações expressas na cadeia alimentar depreende-se facilmente que alterações em qualquer dos elementos de um ecossistema podem refletir-se e ampliar-se levando a conseqüências de difícil previsão e avaliação.

Discutindo a aplicação dos conceitos de biologia na elaboração de projetos, programas e políticas, ORTOLANO (1997) destaca três assuntos freqüentemente presentes na avaliação das transformações causadas por ações humanas nos ecossistemas. São eles:

- biodiversidade e fragmentação de hábitats;

- diversidade de espécies e sua conexão hipotética com a estabilidade dos ecossistemas; e

- espécies significativas, incluindo espécies estruturais e espécies indicadoras.

O termo biodiversidade, ou diversidade biológica, refere-se à variedade e variabilidade de organismos vivos e das comunidades biológicas em que vivem (CANTER, 1996). A biodiversidade pode ser dividida em três categorias hierarquizadas: genes, espécies e ecossistemas.

A diversidade genética refere-se à variação dos genes dentro das espécies, podendo aplicar-se a uma ou várias populações. WORLD RESOURCES...(1992) ilustra este conceito citando as milhares de variedades tradicionais do arroz da Índia. A diversidade genética está relacionada diretamente com a sobrevivência da espécie, na medida em que a disponibilidade de material genético diversificado aumenta as possibilidades de adaptações a novas condições ambientais ou resistência a agentes agressivos. 
A variedade de espécies existentes dentro de uma região define a diversidade de espécies, cuja medida considera não somente o número de espécies em uma dada região, mas também a relação das espécies entre si. Por exemplo, uma ilha com duas espécies de pássaros e uma de lagarto tem maior diversidade de espécies do que uma outra com apenas três espécies de pássaros. Assim, apesar de o número de espécies que vive na terra ser muito maior do que no mar, a diversidade nos ecossistemas marinhos é maior do que nos terrestres porque espécies terrestres estão mais intimamente relacionadas entre si do que as marinhas (WORLD RESOURCES..., 1992).

A diversidade de ecossistemas refere-se à variação na composição, estrutura e funções das comunidades biológicas e seus hábitats. Sua medida é dificultada pela indefinição das fronteiras dos ecossistemas e das associações entre seus componentes.

ORTOLANO (1997) considera ainda uma quarta categoria de biodiversidade, a diversidade regional, que diz respeito às condições que uma região oferece para que as espécies que ali vivem possam deslocar-se. A possibilidade de migração em grandes áreas é condição de sobrevivência para algumas espécies.

A importância da conservação da biodiversidade normalmente é relacionada a avanços, passados e potenciais, em medicina, agricultura e indústria. A existência de muitas espécies de um produto agrícola, cada uma com distinta composição genética, por exemplo, pode tornar possível o desenvolvimento de variedades mais resistentes a determinadas pragas. Mais recentemente, a preservação de ecossistemas naturais tem sido defendida também por razões comerciais ligadas à indústria do ecoturismo, que vem atraindo um número cada vez maior de pessoas no mundo todo.

Todos esses argumentos refletem uma perspectiva antropocêntrica ou utilitarista. Há, porém, grupos que defendem a preservação da diversidade biológica por acreditar que os seres humanos são membros da comunidade biológica e, nesta condição, devem tratar os demais membros com respeito. Muitas pessoas acreditam que os hábitats e espécies devem ser preservados simplesmente porque existem.

Sejam quais forem as razões alegadas, a conservação da biodiversidade é hoje uma das grandes preocupações da humanidade e a fragmentação de hábitats é considerada uma das ameaças significativas a esse objetivo. Projetos lineares, como estradas, linhas de transmissão de eletricidade, dutos para transporte de líquidos, gases ou polpas, freqüentemente dividem hábitats em áreas pequenas demais para as necessidades de espécies que ali vivem. A solução normalmente proposta para este 
problema é a criação de corredores que possibilitem aos animais locomover-se entre as áreas. É uma medida recomendável, porém nem sempre eficaz; o efeito borda, associado à maior extensão de contato entre as áreas naturais e as perturbadas, pode ser danoso ao ecossistema natural, tanto pela alteração de condições climáticas - ventos e temperaturas -, como pela maior exposição das espécies aos predadores.

A diversidade de espécies, de acordo com ORTOLANO (1997), tem sido freqüentemente associada à resiliência dos ecossistemas, ou seja, à habilidade de um ecossistema resistir a pressões ou retornar ao equilíbrio após tê-las sofrido. Muitos biólogos, segundo este autor, acreditam que a estabilidade cresce com a diversidade de espécies. A explicação para esta correlação presumida é que em ecossistemas de alta diversidade as inter-relações entre espécies são complexas e há muitos mecanismos alternativos de ajuste às perturbações.

Ao longo das duas últimas décadas, no entanto, numerosos estudos baseados em modelos matemáticos e observações de campo levaram os biólogos a abandonar a hipótese de conexão entre diversidade e estabilidade em sua forma original. Mesmo assim, conclui o autor, a diversidade de espécies continua a receber atenção em estudos sobre os efeitos de ações humanas sobre ecossistemas.

Tendo em vista o grande número de espécies que geralmente ocorre em um ecossistema, é impraticável a análise dos efeitos das ações humanas em todas as espécies. A escolha de quais espécies estudar recai, geralmente, sobre três grupos: espécies raras, espécies estruturais e espécies indicadoras.

O conceito de raridade não é atribuído somente a espécies, mas também a hábitats. As razões enumeradas para a preservação de espécies e hábitats raros decorrem, principalmente, do desconhecimento do papel que desempenham na manutenção da integridade dos ecossistemas e também de seu valor potencial. O Brasil, assim como diversos países, possui leis específicas de proteção a espécies e hábitats ameaçados de extinção, o que torna obrigatória a análise destes elementos em estudos de impacto ambiental sempre que eles estiverem presentes.

Outro critério de seleção de espécies para estudo é o de espécies estruturais, ou seja, aquelas que, por desempenhar um papel fundamental na dinâmica das relações dentro de um ecossistema, ao serem eliminadas provocam mudanças significativas. Como exemplo, podem-se citar certos predadores cuja ausência favorece a proliferação excessiva de seu alimento - animais ou vegetais - que passam a consumir alimentos 
em taxas superiores às que o meio consegue repor ou ocupar o território impedindo o desenvolvimento de outras espécies.

O terceiro critério, espécies indicadoras, refere-se às espécies que, por responderem mais rapidamente a determinados agentes, permitem a identificação de alterações em um ecossistema, como a presença de poluentes, por exemplo. ORTOLANO (1997) cita o exemplo dos musgos, que sofrem os efeitos da poluição do ar antes de outras plantas por absorverem água e nutrientes diretamente do ar e da água de chuva.

As atividades de mineração afetam os ecossistemas principalmente pela alteração ou destruição de hábitats, o que, por sua vez, resulta em danos à fauna. Nos itens anteriores, foram discutidos diversos impactos da atividade de mineração sobre o meio físico que, dependendo das características de ocupação da área de influência do projeto, podem causar prejuízos ao meio biológico.

Um novo exame do Quadro 3.4 (Poluentes das águas mais comuns em mineração) evidencia os principais efeitos da mineração sobre a biota aquática que, considerada no contexto da cadeia alimentar, pode ter reflexo na avifauna, na fauna terrestre e mesmo nos homens. É o caso, bastante conhecido, da contaminação por mercúrio nos rios e igarapés em áreas de garimpo de ouro, na Amazônia. EYSINK et al. (1988) constataram que, em alguns pontos do rio Ribeira de Iguape e seus afluentes, no Estado de São Paulo, havia chumbo nas águas em níveis até 730 vezes superiores ao limite máximo recomendado para a preservação da vida aquática. Tais concentrações, em virtude da localização dos pontos mais críticos, foram atribuídas, principalmente, à atividade de mineração de chumbo desenvolvida na região em diversas minas desde o início do século XX.

Impacto bastante comum no Estado de São Paulo é o soterramento de comunidades bentônicas por finos provenientes da lavagem de areia em minerações em leito de rio ou em suas margens. BOUCHAUD et al. (1979 apud LEFEUVRE, 1986) compararam populações de organismos bentônicos a montante e a jusante de uma mineração de areia por dragagem em leito de rio e observaram uma redução $52 \%$ e $81 \%$, respectivamente, na densidade numérica e na biomassa desses organismos. Nesta mesma atividade, a presença de sólidos em suspensão atinge vários elementos da cadeia alimentar, resultando no empobrecimento generalizado da população de peixes e na rarefação de certas espécies. 
A falta de um adequado gerenciamento das águas de drenagem das minas em geral pode provocar desde o assoreamento de rios até a contaminação do lençol freático e das águas superficiais, atingindo, num primeiro momento, a fauna aquática e a flora irrigada por estas águas, refletindo-se, em seguida, por toda a cadeia alimentar.

A poluição do ar, conforme destacado no item correspondente, é capaz de causar danos a florestas situadas a distâncias consideráveis dos pontos de emissão. Levando em conta, no entanto, as características da mineração no Estado de São Paulo, cujo principal poluente atmosférico é representado pelo material particulado, os efeitos deste tipo de poluição restringem-se, geralmente, a uma área de influência pequena, uma vez que os particulados tendem a sedimentar-se em um tempo relativamente curto.

Os ruídos e as vibrações transmitidas pelo ar ou pelo solo, provenientes das operações de desmonte de rochas por explosivos, transporte e britagem, entre outras, podem causar prejuízos à fauna, seja afugentando-a das proximidades, seja causando tensão que venha a se refletir na capacidade de procriação ou de cuidar de suas crias.

Os ecossistemas podem ser ainda afetados pela mineração diretamente pela destruição dos hábitats por meio do desmatamento de áreas para a implantação da mina, pilhas de estéril, pátios de manobras, vias internas de circulação, bacias de rejeito e usinas de tratamento de minérios. O desmatamento pode ocorrer ainda fora da área do empreendimento, na abertura de vias de acesso e para escoamento da produção, na implantação de vilas mineiras ou outras atividades induzidas pelo projeto ou para obtenção de madeira para uso energético no processo de produção.

A exploração de granito ornamental em São Paulo freqüentemente requer mais desmatamento para garantir o acesso aos matacões do que para as atividades de extração propriamente ditas. A queima de madeira, nativa ou plantada, em fornos cerâmicos descontínuos, é hoje uma prática menos comum no Estado, até porque os remanescentes florestais estão cada vez mais escassos e a fiscalização está mais presente. No passado, entretanto, esta era uma forma bastante disseminada de destruição de hábitats associada à atividade de mineração.

Outra forma direta de alteração ou destruição de hábitats é o desvio ou barramento de rios, seja para obtenção de água para as atividades de lavra ou tratamento de minérios, seja para permitir o acesso a depósitos minerais subaquáticos.

No Brasil, diversas leis protegem os ecossistemas e a biodiversidade. No âmbito federal, uma das mais importantes e pioneiras é a Lei no 4771 , de 15/09/65 (alterada 
pelas leis $\mathrm{n}^{\text {os }}$ 5106/66, 5868/72, 5870/73 e 7803/89), que instituiu o Código Florestal. Este código limita o exercício do direito de propriedade sobre as florestas e demais formas de vegetação reconhecidas como de utilidade às terras que revestem (Art. $1^{\underline{o}}$ ). Além disso, estabelece várias restrições, sendo as seguintes as que mais afetam as atividades de mineração:

- Art. $2^{\underline{0}}$ - “Consideram-se de preservação permanente, pelo só efeito desta Lei, as florestas e demais formas de vegetação natura 23 ituadas:

a) ao longo dos rios ou de qualquer curso d'água desde o seu nível mais alto em faixa marginal cuja largura seja....;

b) ao redor de lagoas, lagos ou reservatórios d'água naturais ou artificiais;

c) nas nascentes, ainda que intermitentes e nos chamados "olhos d'água", qualquer que seja a sua situação topográfica, num raio mínimo de $50 \mathrm{~m}$ (cinqüenta metros) de largura;

d) no topo dos morros, montes, montanhas e serras;

e) nas encostas ou partes destas, com declividade superior a $45^{\circ}$, equivalente a 100\% na linha de maior declive;

f) nas restingas, como fixadoras de dunas ou estabilizadoras de mangues;

g) nas bordas dos tabuleiros ou chapadas, a partir da linha de ruptura do relevo, em faixa nunca inferior a $100 m$ (cem metros) em projeções horizontais;

h) em altitude superior a $1800 m$ (mil e oitocentos metros), qualquer que seja a vegetação".

- Art. $3^{\underline{0}}$ - "Consideram-se, ainda, de preservação permanente, quando assim declaradas por ato do Poder Público, as florestas e demais formas de vegetação natural destinadas:

a) a atenuar a erosão das terras;

b) a fixar as dunas;

c) a formar faixas de proteção ao longo de rodovias e ferrovias;

d) a auxiliar a defesa do território nacional a critério das autoridades militares;

e) a proteger sítios de excepcional beleza ou de valor científico ou histórico;

f) a asilar exemplares da fauna ou flora ameaçados de extinção;

g) a manter o ambiente necessário à vida das populações silvícolas;

h) a assegurar condições de bem estar público”.

\footnotetext{
${ }^{23}$ O uso do termo natural, na interpretação de técnicos da Secretaria do Meio Ambiente de São Paulo, engloba tanto a vegetação nativa como a plantada.
} 
- Art. $5^{0}$ O Poder Público criará Parques Nacionais, Estaduais e Municipais e Reservas Biológicas, onde fica proibida qualquer forma de exploração dos recursos naturais.

- Art. 26 - Constituem contravenções penais:

a) “destruir ou danificar a floresta considerada de preservação permanente, mesmo em formação, ou utilizá-la com infringência das normas estabelecidas ou previstas nesta Lei;

b) cortar árvores em florestas de preservação permanente, sem permissão da autoridade competente;

g) impedir ou dificultar a regeneração natural de florestas e demais formas de vegetaçã $o^{25,}$

O Código Florestal define, ainda, as situações em que seria admitida a supressão total ou parcial de floresta de preservação permanente e os limites para a derrubada de florestas de domínio privado não sujeitas ao regime de utilização restrita. Muitos destes dispositivos, entretanto, foram superados com a edição do Decreto Federal nº 750 , em 10/02/93, que trata especificamente da vegetação da Mata Atlântica.

A Mata Atlântica é um complexo de florestas que recobria a costa leste do País em área superior a 1,3 milhão de quilômetros quadrados, em 17 Estados brasileiros, ocupando cerca de $15 \%$ do território nacional, dos quais restam hoje poucos remanescentes. No Estado de São Paulo, seus domínios presumivelmente avançavam até o extremo oeste em 1500, restando, em 1995, apenas cerca de 7,6\%, como ilustra a Figura 3.5. (FUNDAÇÃO SOS MATA ATLÂNTICA/INPE/ISA, 1998)

\footnotetext{
${ }^{24}$ Este artigo foi revogado pela Lei $\mathrm{n}^{\mathrm{o}}$ 9.985, de 18/07/2000, que institui o Sistema Nacional de Unidades de Conservação da Natureza (SNUC) e estabelece critérios e normas para a criação, implantação e gestão das unidades de conservação.

${ }^{25}$ Com base nesta alínea, as minerações de areia por dragagem em leito de rio têm sido autuadas no Estado de São Paulo por manterem pilhas, silos, pátios de manobra etc. em área de preservação permanente.
} 


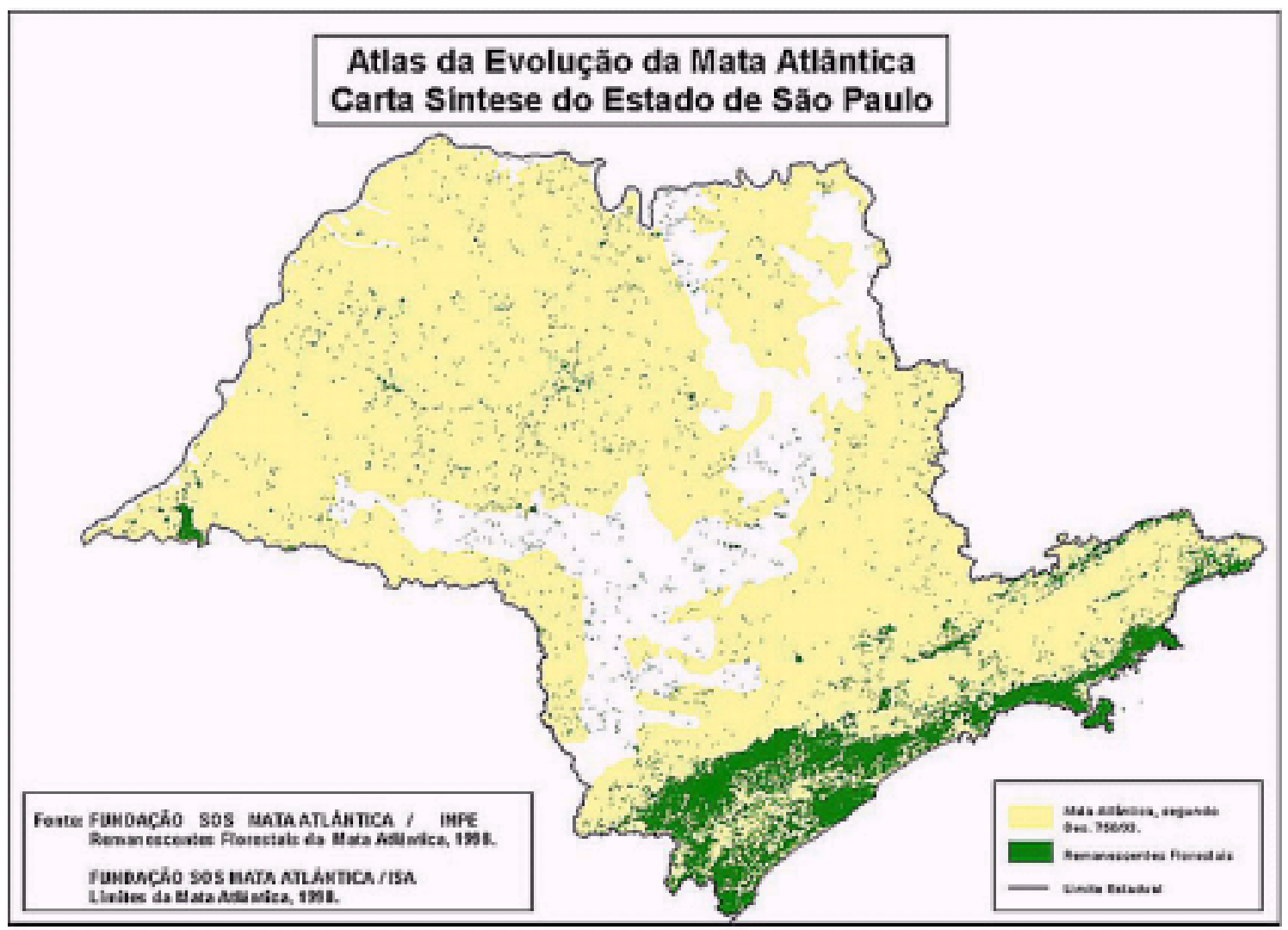

Figura 3.5: Remanescentes Florestais da Mata Atlântica em 1995.

Fonte: FUNDAÇÃO SOS MATA ATLÂNTICA/INPE, 2000

O Decreto Federal nำ 750/93, em seu artigo $1^{\underline{0}}$, proíbe "o corte, a exploração e a supressão de vegetação primária nos estágios avançado e médio de regeneração da Mata Atlântica." O parágrafo único deste artigo, no entanto, admite, em caráter excepcional, a supressão destes tipos de vegetação, quando necessária à execução de obras, planos, atividades ou projetos de utilidade pública ou interesse social, mediante aprovação de estudo de impacto ambiental. Para a Secretaria do Meio Ambiente do Estado de São Paulo toda a atividade de mineração deve ser considerada de utilidade pública e interesse social, uma vez que a Constituição Federal enquadra essa atividade na categoria de interesse nacional (EIGENHEER, 1994 apud DIAS; SÁNCHEZ, 1999).

Além desses dispositivos legais abrangentes, existem os específicos relacionados às unidades de conservação: parques, reservas biológicas, estações ecológicas e áreas de proteção ambiental.

No tocante à proteção à fauna silvestre no território paulista, merece destaque a recente promulgação do Decreto Estadual n⿳⺈ 42.828, de 04/02/98, no qual são declaradas "ameaçadas de extinção" e "provavelmente ameaçadas de extinção", 313 e 213 espécies de animais, respectivamente. 
O gerenciamento dos impactos da mineração no meio biológico inicia-se na fase dos estudos de base e engloba seis tópicos principais, conforme proposto por SÁNCHEZ26.

1. Estudos de base. Compreende a execução de levantamentos adequados (mapeamento de biótipos, levantamentos de vegetação, levantamentos faunísticos terrestres e aquáticos), devidamente registrados, em cooperação com instituições de pesquisa. Nesta fase devem ser escolhidos os indicadores para posterior monitoramento.

2. Minimização das áreas de desmatamento. Alguns preceitos básicos devem ser seguidos na condução de um projeto mineiro: manter áreas de preservação permanente, evitar a formação de ilhas de vegetação pequenas demais para assegurar a viabilidade de populações faunísticas, as áreas remanescentes de vegetação devem ser ligadas por corredores, as áreas sob influência direta da mina devem ser ligadas com outras manchas de vegetação existentes nos arredores, o cronograma de desmatamento deve ser ajustado ao cronograma da lavra, a recuperação das áreas afetadas ou de áreas de compensação deve ser progressiva,

3. Recuperação de áreas degradadas. São os preceitos: utilizar preferencialmente espécies nativas para revegetação, criar e manter viveiro de mudas e utilizar critérios ecológicos na recuperação.

4. Compensação. Compensar a remoção de vegetação pela preservação de áreas nas imediações da mina e recuperar e revegetar áreas degradadas externas à mina.

5. Monitoramento. Acompanhar e registrar sistematicamente os impactos e os resultados das ações de recuperação ambiental.

6. Conscientização e educação. Promover o desenvolvimento ativo de empregados e comunidade.

\subsection{Impactos sobre o Meio Antrópico}

A identificação e avaliação dos impactos de uma ação sobre o meio antrópico pressupõem a compreensão das complexas relações sociais, econômicas e culturais que permeiam a humanidade. Estas relações vão além das trocas de massa e energia e envolvem memória, emoções, crenças e aspirações dos seres humanos. Dificilmente um projeto industrial, seja de mineração ou de outra modalidade qualquer, deixará de causar impactos sobre o meio antrópico.

${ }^{26}$ SÁNCHEZ, L. E. (Epusp) Notas de aula, 1996. 
Tais impactos podem ter caráter benéfico ou adverso e o processo de avaliação deve ser capaz de confrontar uns e outros e chegar a um resultado deste balanço entre custos e benefícios. Neste exercício, entretanto, é de fundamental importância a identificação precisa dos diversos grupos afetados, pois freqüentemente os benefícios são auferidos por grupos diferentes daqueles que arcam com os custos, ou seja, o resultado do balanço pode até ser o equilíbrio, mas as comunidades locais, que vivem no entorno do projeto ficam com os impactos negativos e os benefícios são apropriados por outros grupos.

Os impactos sobre o meio antrópico são usualmente classificados em: sociais, econômicos e culturais. A distinção entre estas categorias nem sempre é fácil e muitos autores preferem tratar os dois primeiros conjuntamente como impactos socioeconômicos. SÁNCHEZ (1995g) considera que esta distinção, apesar de ser às vezes difícil e desnecessária, é importante em muitos casos, por permitir uma análise mais profunda e facilitar a proposição de medidas de atenuação dos impactos negativos ou potencialização dos positivos.

Os impactos sobre o meio antrópico resultantes das atividades de mineração, na maior parte das vezes, são desdobramentos dos impactos no meio físico e nos ecossistemas. Adotando-se a lista sugerida por SÁNCHEZ (op. cit.), o Quadro 3.10 relaciona os principais impactos da atividade, categorizados em sociais, econômicos e culturais.

\begin{tabular}{|l|l|}
\hline \multicolumn{2}{|c|}{ IMPACTOS SOCIAIS } \\
\hline Impacto visual & Alteração da dinâmica demográfica \\
\hline Desconforto ambiental & Remoção de pessoas \\
\hline Impactos sobre a saúde & Qualificação de mão-de-obra \\
\hline Alteração das formas de uso do solo & \\
\hline \multicolumn{2}{|c|}{ IMPACTOS ECONÔMICOS } \\
\hline Aumento da demanda por serviços sociais & Alteração das opções de uso do solo \\
\hline Aumento da demanda por infra-estrutura & Aumento da oferta de empregos \\
\hline Aumento local de preços de bens e serviços & Incremento da atividade econômica \\
\hline Substituição de atividades econômicas & Indução ao desenvolvimento regional \\
\hline Diminuição da produtividade dos ecossistemas & Aumento da arrecadação tributária \\
\hline \multicolumn{2}{|c|}{ IMPACTOS CULTURAIS } \\
\hline Perda de patrimônio & Alteração das relações socioculturais \\
\hline
\end{tabular}

Quadro 3.10: Principais impactos da mineração sobre o meio antrópico Fonte: SÁNCHEZ (1995g) 
Os impactos da mineração sobre o meio antrópico revestem-se de especial importância no Estado de São Paulo devido ao alto grau de ocupação humana peculiar ao território paulista e às características dos bens minerais produzidos — principalmente de uso na construção civil —, usualmente explorados em locais próximos aos centros urbanos.

É o caso, por exemplo, dos impactos visuais, cuja avaliação depende, além da sua magnitude, relacionada aos volumes de rocha e solo movimentados e às dimensões da cava ou frente de lavra, da sua visibilidade, ou seja, do número de pessoas que as vêem (SÁNCHEZ, op. cit.). Considerando os fatores de ocupação e localização mencionados, a maioria dos empreendimentos mineiros no Estado apresenta alta visibilidade. A avaliação dos impactos visuais depende ainda da percepção que as pessoas têm daquela paisagem, o que está relacionado ao senso estético e é fortemente influenciado por fatores culturais e emocionais.

Um caso emblemático da importância deste impacto é o da mineração de ferro no município de Itabira, em Minas Gerais, que eliminou da paisagem da cidade o Pico do Cauê que, com seus 1340 metros, compôs a linha do horizonte da infância e juventude de toda uma geração. Sobre esta perda escreveu o poeta Carlos Drummond de Andrade: "o maior trem do mundo leva meu tempo, minha infância, minha vida, triturada em 163 vagões de minério e destruição ...”.

O desconforto ambiental e os impactos sobre a saúde são causados, geralmente, pela poluição sonora, do ar, da água e do solo, já discutidas nos itens precedentes. É importante destacar, neste sentido, que o desconforto ambiental pode ser sentido mesmo quando as emissões estiverem abaixo dos padrões ambientais estabelecidos. Os impactos sobre a saúde, por outro lado, dificilmente ocorrem quando estes limites são respeitados. Do mesmo modo que o impacto visual, estes são agravados no Estado de São Paulo em face da proximidade entre minerações e áreas habitadas.

A alteração das formas de uso do solo raras vezes tem importância significativa na avaliação de projetos de mineração no Estado de São Paulo. Considerando-se, no entanto, a tendência à formação de pólos de produção, já discutidos anteriormente, podem-se observar áreas extensas nas quais a atividade agrícola foi substituída pela mineração. É o caso de vários pólos de produção de areia para construção civil que transformaram várzeas de rios outrora utilizadas para agricultura em uma sucessão de lagoas. 
Os outros três tipos de impacto social relacionados por SÁNCHEZ (1995g) alteração da dinâmica demográfica, remoção de pessoas e qualificação de mão-de-obra têm importância restrita em São Paulo devido ao alto grau de ocupação do seu território.

A alteração da dinâmica demográfica, representada pela indução de novos fluxos migratórios, pode ser observada em situações específicas como, por exemplo, a atração de trabalhadores de regiões especializadas da Bahia para a produção de pedra de cantaria (paralelepípedos, guias, sarjetas) na região metropolitana de São Paulo. Tratase de atividade artesanal comum em certas regiões produtoras da Bahia, onde é muito mal remunerada, razão pela qual estes trabalhadores treinados são facilmente atraídos para a região sul.

Tendo em vista que as minas em São Paulo são, em geral, de pequeno e médio porte, a remoção de pessoas para implantação de novos projetos tende a ser restrita e pouco comum. O que ocorre, às vezes, é que a presença da mina, em vista dos incômodos que causa, provoca a "expulsão" dos habitantes do entorno.

Os problemas associados à qualificação de mão-de-obra, ou seja, geração de postos de trabalho não compatíveis com a qualificação da mão-de-obra disponível na região e conseqüente atração de trabalhadores de outros locais, são incomuns e específicos em São Paulo, devido às pequenas distâncias entre minas e centros urbanos, além da infra-estrutura rodoviária amplamente distribuída.

Os impactos classificados como econômicos estão muitas vezes intimamente associados aos impactos sociais e, assim como estes, comumente decorrem dos impactos no meio físico e nos ecossistemas. As peculiaridades do setor mineral paulista e suas relações com as demais atividades econômicas e formas de ocupação do solo determinam a maior ou menor significância de determinados tipos de impacto.

Questões relacionadas ao aumento da demanda por serviços sociais e infraestrutura, incluindo infra-estrutura viária, escolas, hospitais, redes de abastecimento de água, redes de esgoto, sistemas de coleta e destinação de resíduos domésticos, são pouco relevantes em decorrência do baixo número de empregos diretos gerados pelos empreendimentos mineiros e sua proximidade aos centros urbanos, o que torna desnecessária a vinda de trabalhadores de outras regiões, exceto em casos específicos. $\mathrm{O}$ mesmo raciocínio se aplica ao aumento local de preços de bens e serviços.

A substituição de atividades econômicas, principalmente atividades tradicionais de baixo impacto ambiental, pode ser considerada um impacto pouco significativo no 
contexto da mineração no Estado, se os projetos forem tratados caso a caso. Uma avaliação por pólos de produção, no entanto, revela profundas alterações na dinâmica social dessas regiões ao longo das últimas décadas.

Decorrente dos impactos no meio físico e biótico, a diminuição da produtividade dos ecossistemas pode atingir a agricultura, a pesca e a criação de animais, com consequiências evidentes na economia local ou regional. A extração de areia em leito de rio, por exemplo, ao lançar poluentes nas águas, causar aumento de turbidez, provocar o soterramento de comunidades bentônicas, causa, freqüentemente, reduções drásticas na população de peixes. Ruídos e vibrações provocados pela detonação de explosivos em pedreiras na área rural podem causar redução na produtividade em criação de aves ou outros animais.

A alteração das opções de uso do solo geralmente está associada às alterações no relevo e nas características do solo na área de influência direta da mina. Na maior parte dos casos, ocorre uma diminuição do número de alternativas de uso, o que não é necessariamente negativo, uma vez que as alternativas de usos finais podem ser melhores do ponto de vista econômico. É o caso de áreas planas ou de relevo suave, inseridas em regiões urbanas ou industriais, resultantes da lavra de areia para construção por desmonte hidráulico. O inverso ocorre no caso da formação de áreas inundadas que, mesmo podendo ser aproveitadas em projetos de recreação, preservação ambiental e outros, apresentam uma gama de alternativas de uso econômico bem mais reduzida do que antes da mineração.

Com relação ao aumento da oferta de empregos, vale destacar que a atividade de mineração gera um número reduzido de empregos quando comparada a outras atividades industriais com valor de investimento equivalente. Nas fases subseqüentes de metalurgia ou industrialização do bem mineral, cresce o número de empregos gerados. Nos pólos de produção mineral existentes em São Paulo, no entanto, a atividade desempenha um papel importante como geradora de empregos, no âmbito local ou regional, contribuindo para a fixação de mão-de-obra fora de centros urbanos.

Do mesmo modo, outro impacto positivo, o incremento da atividade econômica, pode ter expressão do ponto de vista local ou regional no caso dos pólos de produção mineral. Analisado do ponto de vista de um único empreendimento, entretanto, este impacto somente será significativo no Estado de São Paulo em casos excepcionais 
como, por exemplo, em algumas regiões menos desenvolvidas do Estado, onde inexistem alternativas para a economia.

A indução ao desenvolvimento regional também só tem relevância nas regiões pouco desenvolvidas do Estado, como é o caso do Vale do Ribeira. Mesmo assim, os resultados somente são positivos quando existe integração entre o projeto mineiro e a população local, na forma de contratação de mão-de-obra e serviços.

Finalmente, o aumento da arrecadação tributária, que não é exclusividade da mineração, é sempre mencionado entre os impactos positivos da atividade. Na prática, entretanto, este aumento nem sempre ocorre com a magnitude prevista, por duas razões principais. A primeira delas é a evasão fiscal, comum em vários setores da economia, mas acentuada na exploração de minerais de uso na construção civil, cujo mercado tem características que dificultam sobremaneira a fiscalização. Outra razão são os subsídios, diretos ou indiretos, que, embora pouco comuns nas relações entre o poder público e o setor mineral no Estado, podem neutralizar os ganhos com arrecadação tributária por décadas.

Com relação à terceira categoria de impactos sobre o meio antrópico, os impactos culturais, sua avaliação deve ter como ponto de partida a definição de patrimônio cultural dada na Constituição Federal brasileira, em seu artigo 216:

"Constituem patrimônio cultural brasileiro os bens de natureza material e imaterial, tomados individualmente ou em conjunto, portadores de referência à identidade, à ação, à memória dos diferentes grupos formadores da sociedade brasileira, nos quais se incluem:

I. as formas de expressão;

II. os modos de criar, fazer e viver;

III.as criações científicas, artísticas e tecnológicas;

IV.as obras, objetos, documentos, edificações e demais espaços destinados às manifestações artístico-culturais;

$V$. os conjuntos urbanos e sítios de valor histórico, paisagístico, artístico, arqueológico, paleontológico, ecológico e científico".

Trata-se de uma definição abrangente, que considera as várias dimensões da questão cultural, tanto as tangíveis, relacionadas nos itens IV e V, como as intangíveis, referidas nos itens I, II e III. GOODLAND; WEBB (1987) em estudo preparado para o Banco Mundial apresentam duas classificações para o patrimônio cultural. A primeira adota como distinção básica os bens tangíveis e não tangíveis, subdividindo os tangíveis em móveis e imóveis. Constituem os bens intangíveis as linguagens, os costumes, as religiões; tangíveis imóveis são cidades, vulcões, quedas d’água e cavernas, entre outros; tangíveis móveis são os fósseis, artefatos, antigüidades etc. 
A segunda classificação trata especificamente de sítios de interesse cultural, agrupando-os em quatro tipos: arqueológicos, históricos, religiosos e naturais. São exemplos de sítios naturais as cavernas, vulcões, gêiseres, cachoeiras, "canyons", sítios paleontológicos e locais-tipo de formações geológicas.

Além dos princípios básicos expressos na Constituição Federal — "o poder público, com a colaboração da comunidade, promoverá e protegerá o patrimônio cultural brasileiro, por meio de inventários, registros, vigilância, tombamento e desapropriação, e de outras formas de acautelamento e preservação” (Art. 216, $\S 1^{\underline{0}}$ ) - outros dispositivos, de alcance local, regional ou temático conferem proteção ao patrimônio cultural, especialmente aos bens tangíveis imóveis.

Um destes dispositivos é o Decreto Federal nº 99.556, de 1 de outubro de 1990, que torna obrigatória a aprovação de estudo de impacto ambiental para ações ou empreendimentos em áreas de ocorrência de cavidades naturais subterrâneas ou de potencial espeleológico, que possam ser lesivos a essas cavidades. Anteriormente trataram da matéria a Resolução Conama $\mathrm{n}^{-}$5, de 6 de agosto de 1987, estabelecendo que na outorga da concessão mineral deve ser considerada a presença de bens de valor natural, científico e cultural, a fim de estender às atividades de mineração a tarefa de proteção ao patrimônio natural e cultural informando, sempre que for o caso, aos órgãos competentes, e a Portaria Ibama no 887, de 15 de junho de 1990. Esta legislação afeta diretamente numerosos empreendimentos minerários em rochas carbonáticas em todo o território nacional e também no Estado de São Paulo.

As maiores agressões ao patrimônio cultural intangível - linguagens, costumes, religiões - ocorrem quando grandes empreendimentos minerários são implantados em áreas remotas, isoladas, promovendo o contato entre trabalhadores da mineração, vindos de outras regiões, e população local, formada em alguns casos por comunidades indígenas, com hábitos, crenças e valores próprios. De acordo com informações veiculadas pelo Instituto Socioambiental (ISA), apesar de a maior parte das comunidades indígenas (60\%) viver na região da Amazônia Legal, existem ainda em São Paulo, principalmente na faixa litorânea, alguns remanescentes. São grupos das etnias guarani e kaingang que, por viverem em regiões mais ocupadas, em contato com outros segmentos da sociedade brasileira, já perderam parcialmente suas línguas maternas e incorporaram em seu cotidiano bens e produtos industrializados (INSTITUTO SOCIOAMBIENTAL, s.d.a). Além das comunidades indígenas, 
registram-se no Estado, mais precisamente no Vale do Ribeira, cerca de 51 comunidades quilombolas, algumas com atuação destacada na luta pelo reconhecimento de seus direitos, em particular o de propriedade definitiva de suas terras (INSTITUTO SOCIOAMBIENTAL, s.d.b).

Com relação aos bens tangíveis imóveis, a mineração pode afetá-los de diversas formas, sendo a intervenção direta na área de interesse cultural a mais radical, como foi o caso do Parque da Rocha Moutonnée, no município de Salto, cuja rocha foi aproveitada para a fabricação de paralelepípedos, mourões de cerca, pedras de calçamento e brita para construção civil por mais de 40 anos, antes da criação do parque (ALMEIDA; CARNEIRO, 1995). Outra forma de agressão é pela emissão de poluentes capazes de causar danos a monumentos ou edifícios localizados no entorno da mina. As vibrações associadas à detonação de explosivos em pedreiras, por exemplo, podem causar rachaduras ou mesmo provocar o desabamento de edificações antigas, de interesse histórico.

Os bens tangíveis móveis — fósseis, artefatos, antigüidades — são muito ameaçados pela mineração, pela própria natureza da atividade. Este perigo agrava-se pela falta de recursos para execução de um amplo projeto de levantamento e cadastramento dos sítios arqueológicos (históricos e pré-históricos) no Brasil, fazendo com que a grande maioria do território brasileiro permaneça culturalmente desconhecida (CALDARELLI; CALDARELLI, 1991).

No que concerne às técnicas de monitoramento e gestão dos impactos sobre o meio antrópico, SÁNCHEZ (1995g) destaca a importância dos indicadores sociais, cujo uso, todavia, não está ainda tão desenvolvido como o de outros indicadores ambientais.

Com relação à mitigação dos impactos sobre o meio antrópico, as medidas que podem ser adotadas variam desde as medidas técnicas, que reduzem os impactos sobre o meio físico e biótico, evitando as consequiências no meio antrópico, até as que interferem diretamente na questão socioeconômica ou cultural. A seguir, são apresentados e comentados alguns exemplos de medidas mitigadoras, com base em SÁNCHEZ (op. cit.).

Para atenuar os impactos visuais, o mais comum é atuar sobre a visibilidade do empreendimento, reduzindo-a pelo plantio de barreiras vegetais ou pela disposição apropriada de pilhas de estéreis. O uso de estéreis para atenuar os impactos visuais 
apresenta a vantagem de solucionar simultaneamente o problema, ou parte dele, da disposição de estéreis.

Com relação aos problemas de desconforto ambiental, muitas vezes as medidas técnicas são insuficientes, visto que o desconforto persiste mesmo quando os padrões ambientais são respeitados. Neste caso, podem ser adotadas medidas de compensação, negociadas com as comunidades afetadas.

Em muitos casos, as medidas mitigadoras dependem de ações do poder público, ao qual os proponentes do projeto devem fazer gestões e, quando possível, participar da solução dos problemas gerados pelo empreendimento. É o caso do aumento da demanda por serviços sociais e infra-estrutura que, dependendo da sua magnitude, requer a participação da empresa por meio da construção de hospitais, postos de saúde, escolas, creches etc.

No caso de ameaça ao patrimônio cultural, em particular os sítios arqueológicos, deve-se proceder a um levantamento durante a fase dos estudos de impacto ambiental de modo a possibilitar a programação de estudos e, eventualmente, escavações de salvamento.

A correta compreensão e avaliação dos impactos de um empreendimento sobre o meio antrópico na fase de elaboração dos estudos de impacto ambiental permite não somente a proposição de medidas mitigadoras e de compensação adequadas, como podem induzir alterações no próprio projeto, evitando situações futuras de solução muito mais difícil e onerosa. 
Capítulo 4

O UNIVERSO DA PESQUISA E A SELEÇÃO DE CASOS PARA ESTUDO

Embora a AIA tenha sido efetivamente implantada no Brasil em janeiro de 1986, com a promulgação da Resolução Conama $\mathrm{n}^{\mathrm{0}}$ 1/86, os primeiros estudos de impacto ambiental foram submetidos à aprovação da Secretaria do Meio Ambiente de São Paulo em janeiro de 1987, um ano depois 27 .

Dados consolidados até dezembro de 1997, por RONZA (1998), indicam que 470 EIAs foram protocolizados no período, ao final do qual pouco mais de $40 \%$ haviam sido aprovados e cerca de $14 \%$ permaneciam aguardando análise. Os demais, em torno de $45 \%$, haviam sido reprovados, arquivados, devolvidos ou retirados.

A predominância de projetos de mineração é nítida, tendo sido contabilizados 259 EIAs $(55,1 \%)$ ao longo dos onze anos analisados por RONZA (op. cit.), que os agrupou, pela natureza do projeto, em: energia, saneamento, resíduos sólidos, sistemas de transporte, sistemas de drenagem, urbanização e lazer, industrial, agropecuária e mineração. A Tabela 4.1, abaixo, resume os dados do período.

Tabela 4.1: EIAs apresentados no período de janeiro/87 a dezembro/97, por tipo de projeto.

\begin{tabular}{l|c|c}
\hline \multicolumn{1}{c|}{ TIPO DE PROJETO } & $\begin{array}{c}\text { NÚMERO DE } \\
\text { EIAs }\end{array}$ & $\begin{array}{c}\text { PARTICIPAÇÃO } \\
(\boldsymbol{\%})\end{array}$ \\
\hline Mineração & 259 & 55,1 \\
\hline Resíduos sólidos & 46 & 9,8 \\
\hline Sistemas de transporte & 43 & 9,1 \\
\hline Urbanização e lazer & 39 & 8,3 \\
\hline Industrial & 22 & 4,7 \\
\hline Saneamento & 19 & 4,0 \\
\hline Energia & 18 & 3,8 \\
\hline Sistemas de drenagem & 15 & 3,2 \\
\hline Agropecuária & 9 & 1,9 \\
\hline
\end{tabular}

${ }^{27}$ RONZA (1998) esclarece, em nota de rodapé, que o único EIA apresentado em 1986 não constava do banco de dados do Programa de Controle e Tramitação de EIAs e Rimas (CTE), no qual se baseou para traçar o panorama da AIA em São Paulo. 


\begin{tabular}{c|c|c}
\hline TOTAL & $\mathbf{4 7 0}$ & \\
\hline Fonte: RONZA (1998) & \multicolumn{2}{|l}{}
\end{tabular}

\subsection{A AIA em São Paulo desde 1987}

O número de EIAs submetidos anualmente à análise pela Secretaria do Meio Ambiente de São Paulo atingiu seu ápice em 1990, com uma centena de documentos, quando começou a declinar, chegando ao final de 1997 com apenas nove estudos apresentados. Embora este declínio esteja provavelmente relacionado também ao comportamento geral da economia, no âmbito restrito do sistema ambiental paulista, pode ser explicado pela adoção da sistemática de dispensa de apresentação de EIA e sua intensificação a partir da edição das resoluções SMA nº 26/93 e SMA nº 42/94. A evolução dos casos é apresentada na Tabela 4.2, por tipo de projeto.

Tabela 4.2: Evolução do número de EIAs apresentados desde 1987, por tipo de projeto.

\begin{tabular}{l|c|c|c|c|c|c|c|c|c|c|c|c}
\hline \multicolumn{1}{c|}{ TIPO DE PROJETO } & $\mathbf{8 7}$ & $\mathbf{8 8}$ & $\mathbf{8 9}$ & $\mathbf{9 0}$ & $\mathbf{9 1}$ & $\mathbf{9 2}$ & $\mathbf{9 3}$ & $\mathbf{9 4}$ & $\mathbf{9 5}$ & $\mathbf{9 6}$ & $\mathbf{9 7}$ & TOTAL \\
\hline Mineração & 19 & 41 & 23 & 59 & 70 & 31 & 6 & 5 & 2 & - & 3 & 259 \\
\hline Resíduos sólidos & 4 & 11 & 2 & 4 & 7 & 7 & 2 & 3 & 1 & 4 & 1 & 46 \\
\hline Sistemas de transportes & 6 & 1 & 9 & 4 & 8 & 7 & 3 & 2 & - & 1 & 2 & 43 \\
\hline Urbanização e lazer & 2 & 5 & 3 & 8 & 6 & 7 & 3 & 4 & - & 1 & - & 39 \\
\hline Industrial & - & 3 & 1 & 4 & 3 & 4 & 1 & 2 & 2 & 2 & - & 22 \\
\hline Saneamento & 1 & 1 & 3 & 6 & 1 & 2 & 1 & 1 & - & 3 & - & 19 \\
\hline Energia & - & 1 & 1 & 9 & 1 & 2 & - & - & - & 1 & 3 & 18 \\
\hline Sistemas de drenagem & 2 & 3 & - & 4 & 2 & - & 1 & 2 & - & 1 & - & 15 \\
\hline Agropecuária & - & 2 & 5 & 2 & - & - & - & - & - & - & - & 9 \\
\hline TOTAL & $\mathbf{3 4}$ & $\mathbf{6 8}$ & $\mathbf{4 7}$ & $\mathbf{1 0 0}$ & $\mathbf{9 8}$ & $\mathbf{6 0}$ & $\mathbf{1 7}$ & $\mathbf{1 9}$ & $\mathbf{5}$ & $\mathbf{1 3}$ & $\mathbf{9}$ & $\mathbf{4 7 0}$ \\
\hline
\end{tabular}

Fonte: RONZA (1998)

A partir destes dados, é interessante destacar a evolução da participação da mineração no total de EIAs apresentados, ilustrada na Tabela 4.3 e na Figura 4.1.

Tabela 4.3: Participação da mineração no total de EIAs apresentados no período janeiro/87 a dezembro/97

\begin{tabular}{c|c|c|c}
\hline ANO & $\begin{array}{c}\text { EIAs DE } \\
\text { MINERAÇÃO }\end{array}$ & EIAs TOTAIS & $\begin{array}{c}\text { PARTICIPAÇÃO } \\
(\boldsymbol{\%})\end{array}$ \\
\hline 1987 & 19 & 34 & 56 \\
\hline 1988 & 41 & 68 & 60 \\
\hline 1989 & 23 & 47 & 49 \\
\hline 1990 & 59 & 100 & 59 \\
\hline 1991 & 70 & 98 & 71 \\
\hline 1992 & 31 & 60 & 52 \\
\hline 1993 & 6 & 17 & 35 \\
\hline 1994 & 5 & 19 & 26 \\
\hline 1995 & 2 & 5 & 40 \\
\hline 1996 & 0 & 13 & 0 \\
\hline
\end{tabular}




\begin{tabular}{c|c|c|c}
\hline 1997 & 3 & 9 & 33 \\
\hline TOTAL & $\mathbf{2 5 9}$ & $\mathbf{4 7 0}$ & $\mathbf{5 5}$ \\
\hline
\end{tabular}

Fonte: RONZA (1998)

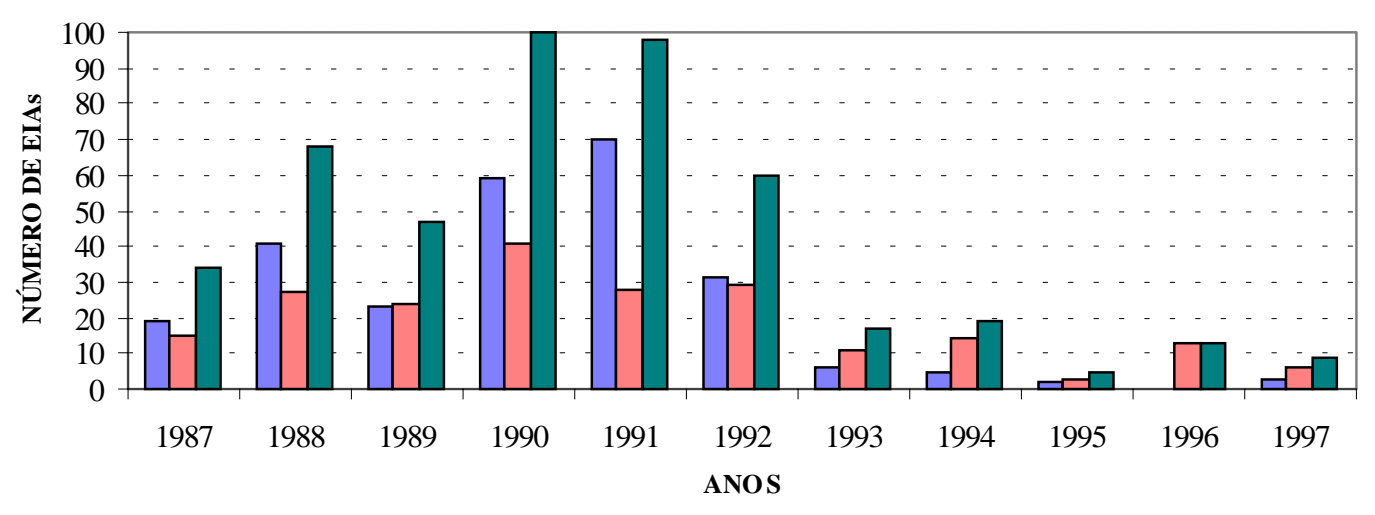

口MINERAÇÃO

$\square$ OUTROS

口TOTAL

Figura 4.1: Evolução do número de EIAs de mineração e de outros projetos no período jan/87 a dez/97

Fonte: RONZA (1998)

Observa-se no gráfico da Figura 4.1 que o declínio do número de EIAs de mineração apresentados inicia-se em 1992 e acentua-se a partir de 1993, quando é ultrapassado largamente pela soma dos estudos relativos a outros tipos de projeto. Alguns fatos ocorridos nesse período podem ser diretamente correlacionados ao fenômeno:

- em 1991, o Daia passou a orientar os escritórios da Cetesb, os consultores especializados e os mineradores, que o procuravam diretamente em busca de informações acerca do processo de AIA, a solicitarem na Cetesb a licença de instalação e somente providenciar a elaboração de estudo de impacto ambiental quando exigido;

- a Cetesb, por sua vez, era orientada a remeter o processo de licenciamento ao Daia para que a necessidade de apresentação de EIA fosse definida por este Departamento;

- em setembro de 1992, foi implantada no Daia a Diretoria de Serviço de Orientação Técnica a Consultas, que passou a coordenar a avaliação preliminar dos impactos ambientais de obras e empreendimentos para definição da necessidade de elaboração de estudo de impacto ambiental; 
- em agosto de 1993 foi editada a Resolução SMA no 26/93 para disciplinar o licenciamento de empreendimentos de mineração no Estado, bem como estabelecer critérios e procedimentos para a exigência de estudos de impacto ambiental.

Não somente na mineração observa-se o declínio do número de EIAs apresentados. Nos demais empreendimentos, este se acentua a partir de 1993, muito provavelmente em decorrência da adoção, nas práticas do Daia, dos procedimentos de triagem que viriam a ser detalhados e formalizados na Resolução n⿳0 42/94.

Esta redução drástica no fluxo de alimentação do sistema foi acompanhada, no entanto, por uma redução no número de EIAs analisados a cada ano, cujo pico ocorreu em 1992, quando o Daia logrou encerrar o trâmite de 84 EIAs, incluindo aprovados, reprovados, arquivados, devolvidos e retirados. A partir de então, esse número caiu anualmente e, embora tenha se mantido superior ao de EIAs apresentados (Tabela 4.4), não foi suficiente para reduzir o "estoque" acumulado, que permanecia, ao final do período, equivalente à soma do número de EIAs apresentados nos cinco anos anteriores.

Tabela 4.4: Evolução do número de EIAs na Secretaria do Meio Ambiente, por situação.

\begin{tabular}{l|c|c|c|c|c|c|c|c|c|c|c|c}
\hline \multicolumn{1}{c|}{ SITUAÇÃOANO } & $\mathbf{8 7}$ & $\mathbf{8 8}$ & $\mathbf{8 9}$ & $\mathbf{9 0}$ & $\mathbf{9 1}$ & $\mathbf{9 2}$ & $\mathbf{9 3}$ & $\mathbf{9 4}$ & $\mathbf{9 5}$ & $\mathbf{9 6}$ & $\mathbf{9 7}$ & TOTAL \\
\hline Apresentados & 34 & 68 & 47 & 100 & 98 & 60 & 17 & 19 & 5 & 13 & 9 & 470 \\
\hline Aprovados & 6 & 19 & 20 & 23 & 42 & 22 & 27 & 6 & 11 & 11 & 6 & 193 \\
\hline $\begin{array}{l}\text { Reprovados, arquivados, } \\
\text { devolvidos ou retirados }\end{array}$ & 1 & 27 & 20 & 8 & 11 & 62 & 27 & 31 & 15 & 5 & 4 & 211 \\
\hline Em análise & 27 & 49 & 56 & 125 & 170 & 146 & 109 & 91 & 70 & 67 & 66 & \\
\hline
\end{tabular}

Fonte: RONZA (1998)

Parte considerável (quase 60\%) desse "estoque" acumulado referia-se a projetos de mineração. Com relação a estes, a redução do número de EIAs analisados a cada ano foi ainda mais notável, tendo passado de 18 em 1995 para 2 no ano seguinte (Tabela 4.5). No próximo item, no qual é discutido em detalhe o universo dos 259 EIAs de mineração aprovados no período, algumas das razões deste comportamento são discutidas.

Dados mais recentes (SÃO PAULO, 2000b) indicam que o "estoque" acumulado de EIAs em análise no Daia foi reduzido, em fevereiro de 2000, a 32 estudos, 12 dos quais $(37,5 \%)$ referentes a atividades de extração mineral. 
Tabela 4.5: Evolução do número de EIAs de mineração na Secretaria do Meio Ambiente, por situação ${ }^{28}$

\begin{tabular}{l|c|c|c|c|c|c|c|c|c|c|c|c}
\hline \multicolumn{1}{c|}{ SITUAÇãOANO } & $\mathbf{8 7}$ & $\mathbf{8 8}$ & $\mathbf{8 9}$ & $\mathbf{9 0}$ & $\mathbf{9 1}$ & $\mathbf{9 2}$ & $\mathbf{9 3}$ & $\mathbf{9 4}$ & $\mathbf{9 5}$ & $\mathbf{9 6}$ & $\mathbf{9 7}$ & TOTAL \\
\hline Apresentados & 19 & 40 & 23 & 58 & 70 & 31 & 5 & 5 & 2 & - & 3 & 256 \\
\hline Aprovados & 2 & 7 & 8 & 10 & 11 & 6 & 19 & 2 & 7 & 2 & 2 & 76 \\
\hline $\begin{array}{l}\text { Reprovados, arquivados, } \\
\text { devolvidos ou retirados }\end{array}$ & - & 23 & 10 & 5 & 5 & 50 & 18 & 19 & 11 & - & 1 & 142 \\
\hline Em análise & 17 & 27 & 32 & 75 & 129 & 104 & 72 & 56 & 40 & 38 & 38 & \\
\hline
\end{tabular}

Fonte: RONZA (1998)

\subsection{Os EIAs de mineração aprovados}

Neste item é apresentado um panorama geral dos estudos de impacto ambiental de empreendimentos minerários aprovados no Estado de São Paulo desde a introdução deste instrumento na sistemática de licenciamento ambiental da atividade.

Os dados foram obtidos em pesquisa direta nos arquivos do Departamento de Avaliação de Impacto Ambiental (Daia), tendo sido preenchidas fichas (Anexo 1) para todos os EIAs aprovados até o mês de outubro de 1997. Foram previstos campos para coleta das seguintes informações: razão social da empresa, nome do empreendimento, município e região administrativa, bacia hidrográfica, substância explorada (principal e associada); produção mensal (ou capacidade instalada); área ocupada; descrição sumária do método de lavra, de beneficiamento e das principais atividades desenvolvidas, situação do projeto (novo, em operação); objeto da licença ambiental (área total, ampliação); audiência pública (houve, não houve); data do protocolo inicial e da decisão final.

A principal fonte dos dados foi o parecer técnico do Daia, suplementado, quando necessário, por informações constantes do processo administrativo, ou seja, correspondências trocadas entre o proponente do projeto ou a empresa de consultoria responsável pela elaboração do EIA e a Secretaria, atas de reunião e outros documentos. Excepcionalmente, consultou-se o EIA ou o Rima quando as informações básicas não constavam do parecer ou do processo.

$\mathrm{Na}$ fase de coleta de dados foi possível observar que várias das informações objetivadas não constavam destes documentos ou não eram apresentadas com a devida clareza. É o caso da bacia hidrográfica, que foi informada em apenas $66 \%$ dos casos.

\footnotetext{
${ }^{28}$ RONZA (1998) apresenta em detalhe apenas os dados referentes aos empreendimentos de mineração privados. Além destes, tramitaram no Daia, no período, três projetos de mineração de responsabilidade do poder público.
} 
Por esta razão, optou-se pela caracterização geográfica baseada na região administrativa, obtida a partir do município.

A substância explorada foi informada em todos os casos, variando o detalhamento da informação. Nos processos mais antigos é comum o emprego do termo "pedra", em referência aos granitos, basaltos ou diabásios empregados na produção de pedras britadas. A produção mensal (ou anual) foi informada em quase todos os processos, porém nem sempre foi possível distinguir-se produção (in situ, lavrada, beneficiada ou comercializada) de capacidade instalada.

A área ocupada constava da maioria dos processos, mas revelou-se um dado pouco confiável, pois os números encontrados, que variaram de 0,5 ha a 300 ha, em alguns casos correspondiam à área da propriedade; em outros, à área do empreendimento; e, em muitos, à área da poligonal requerida para pesquisa ao DNPM, que é notoriamente muito superior à área efetiva de implantação do projeto. Deste modo, esta informação teve de ser descartada na caracterização inicial do universo, sendo retomada na análise dos casos selecionados para estudo.

A descrição dos métodos de lavra, beneficiamento e operações auxiliares, apesar de apresentar muitas imprecisões, propiciou uma idéia geral do tipo de atividade desenvolvida em cada empreendimento.

A situação do projeto, surpreendentemente, revelou-se um dado de difícil obtenção ou pouco confiável. A maioria dos pareceres referiam-se aos empreendimentos como sendo projetos novos. A situação real muitas vezes só era revelada quando o processo continha laudo de vistoria. Em muitos casos, a condição de novo empreendimento baseava-se em aspectos administrativos como mudança de razão social, reativação de área lavrada ou simplesmente empreendimento em operação sem licença ambiental, que era tratado como novo para efeito de licenciamento. Nos casos de ampliação, os dados de produção, área etc. referiam-se, geralmente, ao empreendimento total.

As principais informações coletadas são apresentadas no Anexo 2, na forma de cinco tabelas que contêm os dados considerados confiáveis. A relação nominal das empresas não é apresentada, para evitar a identificação dos casos selecionados para estudo.

Foram 77 EIAs aprovados desde 1987. A Tabela 4.6 mostra a evolução ano a ano do número de EIAs aprovados, referenciados ao ano em que foram protocolizados e 
ao ano em que foram aprovados. Adicionalmente, observa-se a evolução do tempo médio entre estas datas.

Tabela 4.6: Evolução da apresentação e aprovação de EIAs de mineração

\begin{tabular}{c|c|c||c|c|c}
\hline $\begin{array}{c}\text { ANO } \\
\text { DE } \\
\text { ENTRADA }\end{array}$ & $\begin{array}{c}\text { TEMPO } \\
\text { APROVADOS }\end{array}$ & $\begin{array}{c}\text { MÉDIO DE } \\
\text { ANÁLISE } \\
\text { (meses) }\end{array}$ & $\begin{array}{c}\text { ANO DA } \\
\text { APROVAÇÃO }\end{array}$ & $\begin{array}{c}\text { TEMPE DEIAs } \\
\text { APROVADOS }\end{array}$ & $\begin{array}{c}\text { MÉDIO DE } \\
\text { ANÁLISE } \\
\text { (meses) }\end{array}$ \\
\hline 1987 & 6 & 9,0 & 1987 & 2 & 7,7 \\
\hline 1988 & 16 & 11,4 & 1988 & 7 & 4,8 \\
\hline 1989 & 14 & 22,9 & 1989 & 9 & 11,9 \\
\hline 1990 & 21 & 33,6 & 1990 & 11 & 15,7 \\
\hline 1991 & 7 & 28,2 & 1991 & 12 & 18,0 \\
\hline 1992 & 7 & 17,8 & 1992 & 5 & 14,4 \\
\hline 1993 & 5 & 19,0 & 1993 & 18 & 25,7 \\
\hline 1994 & 1 & 28,4 & 1994 & 2 & 29,8 \\
\hline TOTAL & $\mathbf{7 7}$ & & 1995 & 7 & 59,3 \\
\hline MÉDIA & & $\mathbf{2 2 , 2}$ & 1996 & 3 & 37,6 \\
\hline & & & 1997 & 1 & 42,6 \\
\hline & & & TOTAL & $\mathbf{7 7}$ & \\
\hline
\end{tabular}

Percebe-se, da observação destes dados, que grande parte dos EIAs aprovados até o momento foram apresentados à Secretaria nos anos de 88, 89 e 90. Observa-se, ainda, um aumento do tempo de análise que, a partir de 93 superou 2 anos e continuou crescendo até alcançar 5 anos em 1995. A Figura 4.2 ilustra o comportamento destes prazos.

Em que pese a considerável redução do "estoque" acumulado de EIAs de mineração revelada por SÃO PAULO (2000b), a questão dos prazos permanece crítica. Dos 12 EIAs de mineração em análise no Daia, apenas três foram apresentados à SMA há menos de dois anos; cinco EIAs foram submetidos entre dois e cinco anos; e três há mais de cinco anos. O mais antigo foi apresentado em 1990, há mais de dez anos. 


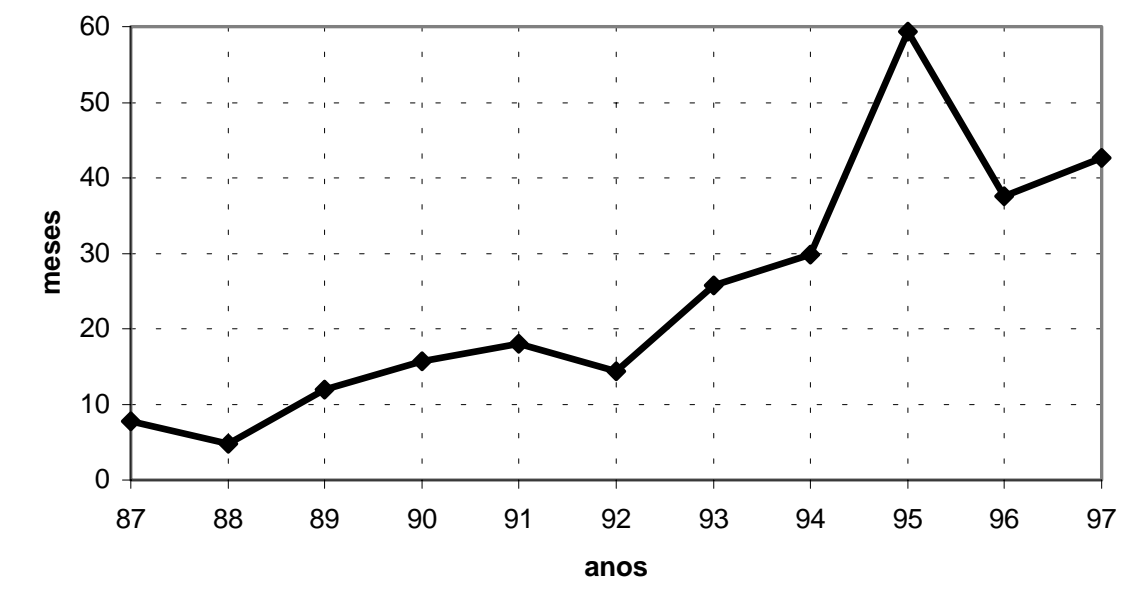

Figura 4.2: Evolução dos prazos de análise por data da aprovação

A maior parte destes estudos tratou de um único empreendimento. Três importantes exceções à regra, no entanto, merecem comentários. Foram os chamados EIAs conjuntos, que, apesar de não previstos na regulamentação, foram aceitos ou mesmo solicitados pela SMA para situações nas quais se configurava um adensamento de empreendimentos similares em uma determinada região geográfica. Os três casos trataram de empreendimentos em funcionamento havia vários anos. $\mathrm{O}$ primeiro deles, apresentado em 1989 pela Associação das Indústrias de Mineração e Extração de Areia do Vale do Paraíba (Aimea I), abrangia 22 portos de areia no município de Jacareí. Em 1993, a Prefeitura Municipal de Araçariguama apresentou o EIA do Distrito Minerário de Araçariguama, abrangendo 11 portos de areia em funcionamento e dois projetados. Ainda em 1993, a Associação dos Extratores de Areia e Argila da Bacia do Rio Jaguari Mirim, nos municípios de Aguaí e São João da Boa Vista, apresentou estudo abrangendo 45 empreendimentos em funcionamento.

Observa-se no Tabela 4.7 a distribuição de EIAs aprovados e número de empreendimentos por substância mineral explorada. A predominância de areia para construção e rocha para produção de brita é marcante. A areia e o quartzito industrial figuram na terceira posição, seguidos por minas de argilas industriais. A argila vermelha comparece isoladamente em apenas dois EIAs aprovados no período, mas é produzida como subproduto da areia para construção em numerosas minas. 
Tabela 4.7: EIAs de mineração aprovados por substância mineral

\begin{tabular}{l|c|c|c|c}
\hline $\begin{array}{c}\text { SUBSTÂNCIA PRINCIPAL } \\
\text { EXPLORADA }\end{array}$ & $\begin{array}{c}\text { NÚMERO } \\
\text { DE EIAs }\end{array}$ & $\%$ & $\begin{array}{c}\text { NÚMERO } \\
\text { DE MINAS }\end{array}$ & $\%$ \\
\hline Areia para construção & 36 & 46,7 & 115 & 73,7 \\
\hline Brita e pedra de talhe & 20 & 26,0 & 20 & 12,8 \\
\hline Areia industrial e quartzito & 8 & 10,4 & 8 & 5,1 \\
\hline Argila industrial & 5 & 6,5 & 5 & 3,2 \\
\hline Argila vermelha & 2 & 2,6 & 2 & 1,3 \\
\hline Calcário dolomítico & 2 & 2,6 & 2 & 1,3 \\
\hline Rocha ornamental & 2 & 2,6 & 2 & 1,3 \\
\hline Turfa & 1 & 1,3 & 1 & 0,6 \\
\hline Bauxita TOTAL & 1 & 1,3 & 1 & 0,6 \\
\hline \multicolumn{1}{c|}{} & $\mathbf{7 7}$ & & $\mathbf{1 5 6}$ & \\
\hline
\end{tabular}

Esta distribuição não reflete o perfil da mineração no Estado de São Paulo; substâncias importantes quanto às quantidades produzidas e valor da produção, como as rochas carbonáticas, aparecem marginalmente, enquanto outras, como as rochas fosfáticas, não aparecem. Tal fato pode ser explicado pelo vínculo entre a AIA e o licenciamento, ou seja, empreendimentos regularmente licenciados pelo órgão ambiental somente submetem EIAs à aprovação no caso de ampliação das atividades.

Muitos dos empreendimentos, entretanto, quando submetidos à aprovação de EIA, já se encontravam em funcionamento havia vários anos, sem as devidas licenças ambientais. A aprovação do EIA era, portanto, necessária para a regularização do empreendimento. Apesar de prevista na ficha de levantamento de dados, a obtenção desta informação não foi possível em grande parte dos casos devido à omissão ou falta de clareza nos registros da Secretaria.

A distribuição geográfica (Tabela 4.8) dos EIAs aprovados também apresenta forte concentração, principalmente se considerado o número de minas incluídas nos estudos. As regiões de Campinas e Limeira apresentam relativa diversidade de substâncias produzidas e destacam-se por incluir a região do rio Jaguari-Mirim com seus 45 portos de areia e extratores de argila. O Vale do Paraíba, região administrativa de São José dos Campos, lidera em número de EIAs aprovados, além de incluir um estudo conjunto de 22 portos de areia no município de Jacareí. Apresenta, também, relativa diversidade de substâncias produzidas, porém a predominância de areia para construção é nítida. Destacam-se, ainda, pelo número de EIAs aprovados e empreendimentos incluídos, as regiões Metropolitana de São Paulo (RMSP) e Sorocaba, que inclui os 13 portos de areia do Distrito Mineral de Araçariguama. 
Tabela 4.8: EIAs de mineração aprovados, por região administrativa e substância produzida.

\begin{tabular}{|c|c|c|c|}
\hline $\begin{array}{c}\text { REGIÃO } \\
\text { ADMINISTRATIVA }\end{array}$ & SUBSTÂNCIA PRODUZIDA & $\begin{array}{l}\text { NÚMERO DE } \\
\text { EIAs }\end{array}$ & $\begin{array}{l}\text { NÚMERO DE } \\
\text { MINAS }\end{array}$ \\
\hline SÃO JOSÉ DOS & Areia para construção & 17 & 39 \\
\hline \multirow[t]{7}{*}{ CAMPOS } & Areia industrial & 1 & 1 \\
\hline & Quartzito industrial & 1 & 1 \\
\hline & Argila bentonítica & 2 & 2 \\
\hline & Brita & 1 & 1 \\
\hline & Argila vermelha & 1 & 1 \\
\hline & Turfa & 1 & 1 \\
\hline & SUBTOTAL & $24(31,2 \%)$ & $46(29,5 \%)$ \\
\hline \multirow{7}{*}{$\begin{array}{l}\text { CAMPINAS E } \\
\text { LIMEIRA }\end{array}$} & Areia para construção & 5 & 50 \\
\hline & Brita & 4 & 4 \\
\hline & Areia industrial & 2 & 2 \\
\hline & Granito ornamental & 1 & 1 \\
\hline & Bauxita & 1 & 1 \\
\hline & Argila cerâmica & 2 & 2 \\
\hline & SUBTOTAL & $15(19,5 \%)$ & $60(38,5 \%)$ \\
\hline \multirow[t]{5}{*}{ RMSP } & Areia para construção & 6 & 6 \\
\hline & Brita & 7 & 7 \\
\hline & Quartzito & 1 & 1 \\
\hline & Argila refratária & 1 & 1 \\
\hline & SUBTOTAL & $15(19,5 \%)$ & $15(9,6 \%)$ \\
\hline \multirow[t]{5}{*}{ SOROCABA } & Areia para construção & 1 & 13 \\
\hline & Calcário dolomítico & 2 & 2 \\
\hline & Brita & 1 & 1 \\
\hline & Argila vermelha & 1 & 1 \\
\hline & SUBTOTAL & $5(6,5 \%)$ & $17(10,9 \%)$ \\
\hline \multirow[t]{4}{*}{ REGISTRO } & Brita & 3 & 3 \\
\hline & Areia para construção & 1 & 1 \\
\hline & Mármore ornamental & 1 & 1 \\
\hline & SUBTOTAL & $5(6,5 \%)$ & $5(3,2 \%)$ \\
\hline \multirow[t]{3}{*}{ CENTRAL } & Areia industrial & 3 & 3 \\
\hline & Areia para construção & 1 & 1 \\
\hline & SUBTOTAL & $4(5,2 \%)$ & $4(2,6 \%)$ \\
\hline SÃO JOSÉ DO RIO & Areia para construção & 2 & 2 \\
\hline \multirow[t]{2}{*}{ PRETO } & Basalto para pedra de talhe & 1 & 1 \\
\hline & SUBTOTAL & $3(3,9 \%)$ & $3(1,9 \%)$ \\
\hline \multirow[t]{3}{*}{ RIBEIRÃO PRETO } & Areia para construção & 1 & 1 \\
\hline & Brita & 1 & 1 \\
\hline & SUBTOTAL & $2(2,6 \%)$ & $2(1,3 \%)$ \\
\hline \multirow[t]{2}{*}{ SANTOS } & Areia para construção & 2 & 2 \\
\hline & SUBTOTAL & $2(2,6 \%)$ & $2(1,3 \%)$ \\
\hline \multirow[t]{2}{*}{$\overline{\text { BAURU }}$} & Brita & 1 & 1 \\
\hline & SUBTOTAL & $1(1,3 \%)$ & $1(0,6 \%)$ \\
\hline \multirow[t]{3}{*}{ MARÍLIA } & Brita & 1 & 1 \\
\hline & SUBTOTAL & $1(1,3 \%)$ & $1(0,6 \%)$ \\
\hline & TOTAL & 77 & 156 \\
\hline
\end{tabular}

Uma análise mais aprofundada dos processos relativos à areia para construção revela os seguintes métodos de lavra adotados: dragagem em leito de rio, dragagem em cava inundada na várzea; desmonte hidráulico e escavação mecanizada. Alguns empreendimentos operavam simultaneamente por dois destes métodos. As faixas de 
produção mensal variaram amplamente, apresentando valores mais elevados nas operações em cava inundada, chegando a atingir cerca de $35.000 \mathrm{~m}^{3} /$ mês de produto. As lavras por desmonte hidráulico mostraram produção na faixa de 3000 a $6000 \mathrm{~m}^{3} / \mathrm{mês}$, enquanto as operações de dragagem em leito de rio, mesmo atingindo cerca de 12.500 $\mathrm{m}^{3} /$ mês, apresentaram as menores produções por empreendimento - a menor é de $600 \mathrm{~m}^{3} /$ mês.

No caso das pedreiras, empregava-se generalizadamente a lavra a céu aberto, por explosivos, independentemente da rocha explorada, que variou conforme a região: granito, diabásio ou basalto. A produção mensal de brita variou em uma ampla faixa, desde $5500 \mathrm{~m}^{3} /$ mês até $110.000 \mathrm{~m}^{3} / \mathrm{mês}$, com média de $28.700 \mathrm{~m}^{3} / \mathrm{mês}$ A região metropolitana de São Paulo concentrava quase $40 \%$ dos casos.

As minas de areia industrial, assim como o quartzito, utilizados principalmente na fabricação de vidros, apresentaram produção mensal variando de 2500 t/mês até

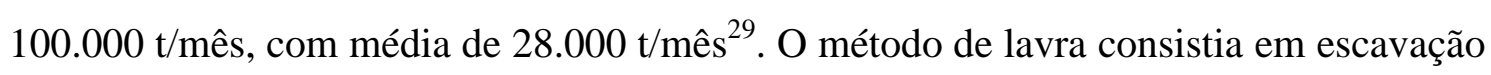
mecanizada associado, em um caso, a desmonte hidráulico. Apenas em uma das minas de quartzito empregava-se o desmonte por explosivos.

As argilas industriais - bentonítica, refratária e cerâmica — eram lavradas a céu aberto, com auxílio de escavadeiras em níveis de produção relativamente baixos, de cerca de 670 t/mês até 3300 t/mês. As argilas vermelhas situavam-se na mesma faixa de produção, utilizando método de lavra semelhante.

As duas minas de calcário dolomítico eram lavradas a céu aberto, com explosivos e produziam 6000 t/mês e 30.000 t/mês, respectivamente. As rochas ornamentais eram lavradas em blocos, com auxílio de explosivos (pólvora) no caso do granito e fio abrasivo no caso do mármore. A produção mensal era de $250 \mathrm{~m}^{3} / \mathrm{mês}$ e 100 $\mathrm{m}^{3} / \mathrm{mês}$, respectivamente.

A produção prevista para a mina de bauxita era de 7000 t/mês, pelo método de escavação mecanizada. A turfa tinha produção prevista de $5600 \mathrm{~m}^{3} / \mathrm{mês}$ por escavação mecanizada.

\footnotetext{
${ }^{29}$ As unidades de medida adotadas são as consagradas no mercado: metros cúbicos para a brita, areia para construção, rochas ornamentais e turfa, e toneladas para os demais.
} 


\subsection{Seleção de casos para estudo}

Previamente à discussão dos critérios para a seleção de casos para estudo e à seleção propriamente dita, cabem algumas considerações a respeito do estudo de caso como método de pesquisa.

O estudo de caso enquadra-se no grupo de métodos de pesquisa denominados qualitativos, que se caracterizam por um foco maior na compreensão dos fatos do que na sua mensuração (LAZZARINI, 1995). De acordo com YIN (1994), o estudo de casos tem sido empregado como método de pesquisa em numerosos campos do conhecimento, notadamente administração e políticas públicas e planejamento urbano e regional, tanto em aplicações práticas como em estudos acadêmicos.

TULL; HAWKINS (1976) destacam como principal característica do método a realização de uma análise intensa de uma situação singular. YIN (op. cit.) acrescenta que o estudo de caso deve cobrir o fenômeno propriamente dito e o contexto no qual ele ocorre, sendo ideal para responder às perguntas "como" e "por que". Na busca da compreensão do fenômeno, os limites entre este e o contexto nem sempre são claramente definidos. Assim, os fatos e seu contexto não se dissociam e as generalizações eventualmente resultantes da pesquisa devem considerar esta limitação.

Reproduzindo um ponto de vista comumente difundido, TULL; HAWKINS (op. cit.) sustentam que o método é mais apropriado em pesquisa exploratória, proporcionando revelações que podem ser utilizadas na formulação de hipóteses. YIN (op. cit.) considera um equívoco esta limitação e defende o emprego do método também para a verificação das hipóteses formuladas. EISENHARDT (1989 apud LAZZARINI, 1995) sugere a utilização do método para ativar um processo de construção teórica.

Um aspecto importante que permeia esta discussão diz respeito aos limites da generalização dos resultados obtidos em estudos de caso. Tendo em mente que os casos em estudo não constituem uma amostra no sentido estatístico, o objetivo do pesquisador deve ser o de formular, expandir ou generalizar teorias (generalização analítica) e não quantificar freqüências (generalização estatística). (YIN, 1994).

A necessidade de se proceder a uma análise profunda de cada caso limita, por razões de prazos e custos, o número de casos a ser estudados. A lógica, neste caso, é a da reprodução do fenômeno.

De acordo com a lógica estatística, um número restrito de indivíduos (a amostra) é assumido como capaz de representar um conjunto maior (a população). Desde que 
precedidos de uma caracterização completa do universo e de procedimentos estatísticos para a seleção da amostra, os dados coletados naquele conjunto restrito de indivíduos podem ser inferidos para toda a população, em um intervalo de confiança definido.

Pelo método escolhido para esta pesquisa, não se trata de selecionar um caso ou um conjunto de casos representativos. Isso não seria possível dada a diversidade do universo em face do grande número de parâmetros que influenciam o resultado.

O estudo de caso como método de pesquisa apresenta duas grandes variantes, o caso único e múltiplos casos. Um único caso pode ser adequado quando se tratar de um caso crítico capaz de confirmar ou refutar uma teoria bem elaborada. Também pode ser utilizado quando for um caso único, extremo ou revelador de determinado fenômeno.

No estudo de casos múltiplos, cada caso estudado é completo em si e revela evidências que se acumulam em diferentes contextos. Deste modo, pode conduzir à reprodução literal, que ocorre quando cada caso apresenta as mesmas evidências, ou à reprodução teórica, quando os casos produzem evidências contrastantes, porém as diferenças podem ser satisfatoriamente explicadas (YIN, 1994).

Nesta pesquisa, em que se pretende avaliar a eficácia de um instrumento de política pública — a avaliação de impacto ambiental — por meio da análise pormenorizada de sua aplicação no contexto do Estado de São Paulo, optou-se por múltiplos casos.

\subsubsection{Critérios para seleção}

Conforme apresentado no item anterior, o conjunto dos EIAs de mineração aprovados desde a implementação do instrumento no Estado é constituído de 77 casos, ou seja, um universo que pode ser classificado como restrito. Se considerados, dentre os parâmetros que influem no tema em estudo, aqueles caracterizados com razoável confiabilidade na fase de levantamento de dados, o universo pode também ser considerado heterogêneo. É possível, contudo, identificar alguns grupos importantes e relativamente homogêneos. Os critérios de seleção dos casos para estudo basearam-se nestes grupos e em alguns critérios de exclusão, expostos e justificados a seguir:

1. EIAs conjuntos. São 5 casos, todos de areia para construção civil e foram excluídos pelo fato de a figura do EIA conjunto não estar prevista na legislação e sua regulamentação, sendo resultado de entendimentos havidos entre o órgão público e 
os proponentes do projeto. Ademais, a avaliação de sua eficácia requereria um estudo específico.

2. EIAs apresentados em 1987. São 6 casos e sua exclusão justifica-se por terem sido os primeiros estudos apresentados e analisados, caracterizando-se pela precariedade do estudo propriamente dito, decorrente da inexperiência das equipes técnicas responsáveis por sua elaboração. Além disso, as equipes técnicas do órgão ambiental, encarregadas da revisão do estudo, também eram inexperientes e os procedimentos ainda não estavam consolidados.

3. Empreendimentos dispensáveis da apresentação de EIA pelos critérios da Resolução $\underline{\text { SMA } n^{0} 26 / 93}$. Embora a aplicação dos critérios de dispensa definidos nesta resolução requeira uma análise pormenorizada do relatório de controle ambiental, pode-se prever, com razoável grau de acerto, que os empreendimentos cuja produção mensal situa-se abaixo de $1000 \mathrm{~m}^{3} /$ mês seriam dispensados da apresentação de EIA pelos critérios atualmente adotados. A aplicação deste critério resultou na exclusão de 6 casos, abrangendo empreendimentos de extração de argila vermelha, mármore e granito ornamentais, areia para construção civil e argila bentonítica.

Com base nestes critérios, foram excluídos 18 casos. Dentre os 59 restantes, a escolha recai nos principais grupos homogêneos por substância explorada. A substância explorada, como se observa dos dados apresentados no item anterior, define o método de lavra e apresenta concentração em determinadas regiões geográficas, devido aos condicionantes geológicos e de mercado.

Definiu-se, então, que seriam estudados seis casos, sendo três de areia para construção, duas pedreiras e uma mina de areia industrial. Do grupo mais importante, areia para construção, cada caso representaria um método de lavra dentre os três mais importantes - desmonte hidráulico, dragagem em cava inundada e dragagem em leito de rio. Dentre as pedreiras seria escolhido um caso em área urbana e outro em área não urbana.

A escolha final dos casos seria feita por meio dos seguintes procedimentos:

1. Ordenação mediante sorteio simples dos casos enquadrados em cada um dos grupos previamente definidos.

2. Escolha do primeiro colocado em cada grupo que satisfizesse as seguintes condições: não estar instalado quando da apresentação e aprovação do EIA, e ter se instalado há pelo menos um ano por ocasião da visita de campo. 
Se não existissem, dentro do grupo objetivado, casos atendendo às condições propostas, estas seriam reavaliadas.

\subsubsection{Escolha final de casos para estudo}

Retomando os principais grupos homogêneos definidos anteriormente a partir das Tabelas 3, 4 e 5 (Anexo 2) e aplicando os critérios de exclusão já discutidos, restaram disponíveis para estudo 24 projetos de lavra de areia para construção civil, sendo 5 por desmonte hidráulico, 10 por dragagem em cava inundada e 9 por dragagem em leito de rio; 18 projetos de lavra de rochas para brita e 5 projetos de lavra de areia industrial.

Estes projetos foram ordenados mediante sorteio simples, utilizando-se a ferramenta Analisar Dados - Amostragem, disponível no aplicativo Microsoft Excel versão 7.0. Foi então realizada nova consulta aos arquivos do Daia, com o propósito de verificar a situação do empreendimento com relação à instalação, tendo-se obtido os seguintes resultados:

\section{Areia para construção com lavra por desmonte hidráulico}

Os três primeiros casos sorteados encontravam-se em operação há vários anos quando da apresentação do EIA, apresentando áreas já impactadas e degradadas. O EIA, nestes casos, formalmente instruía ou um pedido de licença de instalação para ampliação — porém a área lavrada já havia ultrapassado largamente a licenciada —, ou um pedido de licença de instalação de empreendimento então irregular. Ou seja, os três processos visavam à regularização perante o órgão ambiental, de empreendimentos existentes havia vários anos (de 4 a 14 anos).

O quarto caso sorteado não havia sido instalado na época, porém, por meio de contatos com técnicos do Daia, da Cetesb e da empresa consultora responsável pela elaboração do EIA, constatou-se que, apesar de aprovado desde o final de 1989, o empreendimento encontrava-se ainda em fase inicial de implantação.

Finalmente, o quinto e último sorteado não estava implantado quando da apresentação do EIA e, embora tenha iniciado os trabalhos de implantação durante a tramitação do processo, encontrava-se em funcionamento, atendendo satisfatoriamente às condições propostas. 


\section{Areia para construção com lavra por dragagem em cava inundada}

O primeiro empreendimento sorteado atendia satisfatoriamente às condições estabelecidas: não estava implantado antes da apresentação e aprovação do EIA e, de acordo com informações obtidas na regional da Cetesb, havia sido implantado há mais de um ano e operava normalmente até o momento.

\section{Areia para construção com lavra por dragagem em leito de rio}

De acordo com os dados disponíveis no processo Daia e no EIA, bem como os obtidos em contato com a empresa consultora responsável pelo estudo e com o minerador, o primeiro empreendimento da lista havia sido instalado após a aprovação do EIA e encontrava-se em funcionamento normal por ocasião da verificação, atendendo, portanto, satisfatoriamente às condições propostas.

\section{Pedreiras}

Dentre as pedreiras, previa-se, originalmente, estudar um caso em área urbana e outro em área não-urbana. O segundo empreendimento da lista, instalado após a aprovação do EIA, satisfazia as condições e situava-se em área rural. Em área urbana, entretanto, nenhum dos empreendimentos da lista satisfazia a condição de ter-se instalado após a aprovação do EIA.

Embora não prevista, essa situação é facilmente compreensível, uma vez que conflitos com população residente no entorno de antigas pedreiras têm sido responsáveis, nos últimos tempos, até pelo fechamento de alguns empreendimentos nessas áreas, o que não estimula a proposição de novos em condições semelhantes. A solução encontrada foi a reavaliação das condições propostas, tendo sido selecionada, como segundo caso de estudo, uma pedreira instalada após a aprovação do EIA em zona de uso predominantemente industrial (Zupi-1), na região metropolitana de São Paulo. O oitavo empreendimento da lista atendia a essas condições. Quanto aos demais, distribuíam-se em casos de regularização perante o órgão ambiental de empreendimentos instalados havia vários anos; outros empreendimentos novos em área rural e outros empreendimentos novos em área de uso industrial.

\section{Areia industrial}

Dentre os cinco projetos de mineração de areia para fins industriais disponíveis para estudo, a situação encontrada foi a seguinte: 
- O primeiro e o quarto casos sorteados referiam-se a antigas minas em processo de regularização perante o órgão ambiental.

- O segundo empreendimento atendia à condição de não estar instalado quando da apresentação e aprovação do EIA. Informações obtidas na regional da Cetesb revelaram, no entanto, que o empreendimento foi instalado após a aprovação do EIA e obtenção das licenças, porém apenas para a produção de areia para construção. Funcionou por pouco tempo, foi desativado e as atividades haviam sido retomadas havia cerca de 3 meses, ainda produzindo apenas areia para construção. A unidade de beneficiamento prevista no EIA nunca funcionou e os equipamentos teriam se deteriorado, segundo informações da regional da Cetesb. Mesmo constituindo um exemplo interessante de descompasso entre o projeto real e o projeto aprovado, este caso não foi considerado adequado para estudo de caso por estar ainda em processo de instalação, ademais por não ilustrar o grupo de empreendimentos de areia industrial.

- O terceiro sorteado também atendia à condição de empreendimento novo, porém foi implantado e desativado pouco tempo depois.

- O empreendimento selecionado foi, portanto, o quinto sorteado, que atendia a ambas as condições estabelecidas: novo e implantado. De acordo com informações fornecidas pela empresa consultora que acompanhava o projeto na ocasião, a mina estava operando normalmente.

O resumo do plano de escolha e os casos escolhidos são apresentados no Tabela 4.9. Observando-se em conjunto os seis casos selecionados, nota-se que a produção mensal dos empreendimentos varia desde $12.000 \mathrm{~m}^{3}$ até $80.000 \mathrm{~m}^{3}$, enquanto a distribuição geográfica atinge as seguintes regiões administrativas do Estado: Região Metropolitana de São Paulo, dois casos de substâncias diferentes em municípios diferentes, e as regiões de São José dos Campos, São José do Rio Preto, Sorocaba e Campinas. Deste modo, os estudos de caso abrangem empreendimentos com produção minerária variada, bem distribuídos geograficamente. Este último parâmetro propicia a observação de eventuais variações nos procedimentos e rotinas de fiscalização em distintas regionais da Cetesb e DEPRN. 
Tabela 4.9: Ordenação de casos para estudo, por substância mineral explorada.

\begin{tabular}{|c|c|c|c|c|c|c|c|c|c|}
\hline \multicolumn{6}{|c|}{ AREIA PARA CONSTRUÇÃO } & \multirow{2}{*}{\multicolumn{2}{|c|}{ BRITA }} & \multirow{2}{*}{\multicolumn{2}{|c|}{$\begin{array}{c}\text { AREIA } \\
\text { INDUSTRIAL }\end{array}$}} \\
\hline \multicolumn{2}{|c|}{$\begin{array}{c}\text { DESMONTE } \\
\text { HIDRÁULICO }\end{array}$} & \multicolumn{2}{|c|}{$\begin{array}{c}\text { CAVA } \\
\text { INUNDADA }\end{array}$} & \multicolumn{2}{|c|}{ LEITO DE RIO } & & & & \\
\hline casos & ordem & casos & ordem & casos & ordem & casos & ordem & casos & ordem \\
\hline 16 & 49 & 27 & 45 & 7 & 34 & 10 & 53 & 15 & 39 \\
\hline 18 & 31 & 36 & 41 & 9 & 7 & 12 & 25 & 19 & 19 \\
\hline 31 & 54 & 41 & 52 & 13 & 57 & 21 & 40 & 28 & 28 \\
\hline 49 & 18 & 42 & 67 & 31 & 32 & 22 & 68 & 29 & 29 \\
\hline \multirow[t]{14}{*}{54} & 16 & 43 & 27 & 32 & 13 & 23 & 21 & 39 & 15 \\
\hline & & 44 & 36 & 34 & 62 & 24 & 50 & & \\
\hline & & 45 & 43 & 35 & 31 & 25 & 75 & & \\
\hline & & 47 & 42 & 57 & 9 & 40 & 12 & & \\
\hline & & 52 & 44 & 62 & 35 & 50 & 55 & & \\
\hline & & 61 & 61 & & & 53 & 24 & & \\
\hline & & 67 & 47 & & & 55 & 69 & & \\
\hline & & & & & & 68 & 70 & & \\
\hline & & & & & & 69 & 23 & & \\
\hline & & & & & & 70 & 74 & & \\
\hline & & & & & & 71 & 71 & & \\
\hline & & & & & & 73 & 22 & & \\
\hline & & & & & & 74 & 10 & & \\
\hline & & & & & & 75 & 73 & & \\
\hline $\mathrm{n}:$ & SO & los & tud & & & & & & \\
\hline
\end{tabular}




\section{Capítulo 5}

\section{ESTUDOS DE CASO}

Os seis casos selecionados para estudo foram submetidos a uma análise detalhada, cujos procedimentos, definidos inicialmente em linhas gerais, foram refinados simultaneamente ao estudo do primeiro caso. Deste modo, o primeiro caso estudado acumulou a função de caso piloto, fornecendo elementos para a programação detalhada de coleta e tratamento das informações.

O Quadro 5.1 resume as principais características dos empreendimentos selecionados para estudo. Escolhidos de acordo com os critérios expostos no capítulo anterior, os seis casos abrangem empreendimentos de porte pequeno a médio, localizados nas principais regiões administrativas do Estado.

\begin{tabular}{|l|ll|}
\hline Caso 1 & $\begin{array}{l}\text { Substância: areia para construção civil } \\
\text { Método de lavra: desmonte hidráulico } \\
\text { Capacidade instalada: } 7500 \mathrm{~m}^{3} / \mathrm{mês}\end{array}$ & Área: 50 ha \\
\hline Caso 2 & $\begin{array}{l}\text { Substância: areia para construção civil } \\
\text { Método de lavra: dragagem em leito de rio } \\
\text { Capacidade instalada: } 5000 \mathrm{~m}^{3} / \mathrm{mês}\end{array}$ & Área: 24 ha \\
\hline Caso 3 & $\begin{array}{l}\text { Substância: pedra britada } \\
\text { Método de lavra: a céu aberto, com explosivos } \\
\text { Capacidade instalada: } 80.000 \mathrm{~m}^{3} / \mathrm{mês}\end{array}$ & Área: 5 ha \\
\hline Caso 4 & $\begin{array}{l}\text { Substância: areia para construção civil } \\
\text { Método de lavra: dragagem em cava inundada } \\
\text { Capacidade instalada: } 24.000 \mathrm{~m}^{3} / \mathrm{mês}\end{array}$ & Área: 42 ha \\
\hline Caso 5 & $\begin{array}{l}\text { Substância: areia industrial } \\
\text { Método de lavra: a céu aberto, escavação mecânica } \\
\text { Capacidade instalada: } 30.000 \mathrm{t} / \mathrm{mês}\end{array}$ & Área: 24 ha \\
\hline Caso 6 & $\begin{array}{l}\text { Substância: pedra britada } \\
\text { Método de lavra: a céu aberto, com explosivos } \\
\text { Capacidade instalada: } 50.000 \mathrm{~m}^{3} / \mathrm{mês}\end{array}$ & Área: 3 ha \\
\hline
\end{tabular}

\section{Quadro 5.1: Casos selecionados para estudo}

Com relação às datas de apresentação à SMA, merece destaque o fato de que em todos os casos selecionados para estudo, o EIA/Rima foi protocolizado na SMA entre os anos de 1988 e 1990 e sua aprovação ocorreu entre os anos de 1989 e 1991. Este fato é uma decorrência não programada dos critérios e procedimentos adotados para a seleção 
dos casos para estudo. Com efeito, pelo segundo critério de exclusão, os estudos apresentados antes de 1988 foram descartados e, pelo segundo procedimento de escolha dos casos, o empreendimento não poderia estar instalado quando da apresentação e aprovação do EIA e teria de estar instalado há mais de um ano por ocasião da visita de campo.

O processo de seleção de casos revelou que os estudos apresentados e aprovados mais recentemente tratavam de regularização de empreendimentos já instalados e em operação há vários anos ou, quando novos, não haviam iniciado ou concluído a etapa de instalação. O fato de os casos estudados terem tido seus EIAs aprovados há vários anos pode ser avaliado como positivo para a pesquisa, pois ampliou o período de observação das ações relativas à implementação das decisões oriundas do processo de AIA, como pode ser observado nos itens subseqüentes deste capítulo.

A partir do primeiro caso, ou caso piloto, desenvolveu-se um formulário para registro das informações coletadas em cada caso. Esse formulário, intitulado "Roteiro e Ficha para Coleta de Dados", é apresentado no Anexo 1 e foi organizado nos seguintes itens:

1. Identificação para contatos posteriores;

2. Documentos consultados;

3. Precedentes;

4. Motivação;

5. Cronologia do processo;

6. Caracterização do empreendimento aprovado no processo de AIA;

7. Medidas mitigadoras e de monitoramento propostas e sua localização nos documentos;

8. Ata de reunião e deliberação do Consema;

9. Processo(s) Cetesb;

10. Processo(s) DEPRN;

11. Mina.

Para cada caso estudado foram consultados todos os documentos que constituem o processo administrativo SMA/Daia, duas coletâneas de atas do Consema disponíveis em publicações e os vários processos existentes nas unidades regionais da Cetesb. Quanto ao DEPRN, das várias tentativas de localização de processos empreendidas, apenas uma teve sucesso. No caso do Dusm, cujo campo de atuação restringe-se aos empreendimentos situados em Áreas de Proteção de Mananciais da Região Metropolitana de São Paulo, nenhum processo foi localizado. 
Além da consulta aos documentos, foram feitas visitas às minas para a observação da implementação do projeto e das medidas mitigadoras e compensatórias definidas no processo de AIA. Foram feitas apenas cinco visitas, um vez que um dos mineradores recusou a autorização para a pesquisa. Nesse caso, a coleta de dados restringiu-se aos documentos disponíveis nos órgãos oficiais, que são de livre consulta pública.

As informações obtidas, registradas no formulário "Roteiro e Ficha para Coleta de Dados", subsidiaram a elaboração de relatórios preliminares para cada um dos casos estudados. Esses relatórios continham a caracterização geral do empreendimento; a descrição dos principais documentos examinados; uma análise preliminar da cronologia do processo; a tipificação das medidas propostas no EIA, no Rima, nos relatórios complementares, no parecer do Daia e na deliberação do Consema; a avaliação da atuação dos órgãos encarregados do acompanhamento da implantação e operação dos empreendimentos após aprovação do EIA/Rima; a avaliação da situação da mina com relação às medidas mitigadoras e de monitoramento definidas no processo de AIA e observações preliminares sobre o caso estudado. Considerando não ser esta a forma de apresentação final da discussão dos casos estudados, procurou-se armazenar nestes relatórios o máximo de informações e observações, relegando-se a plano secundário questões de forma.

Com base nas informações registradas nesses relatórios, procedeu-se, então, à consolidação dos resultados da pesquisa, que é apresentada a seguir.

\subsection{Principais documentos examinados}

O primeiro arquivo consultado, que já havia sido utilizado para a caracterização do universo da pesquisa e seleção de casos para estudo, foi o arquivo do Daia. Sua consulta é livre e não foi necessária autorização do proponente do projeto, bastando uma solicitação formal emitida pela Escola Politécnica, com a devida exposição de motivos. Os principais documentos ali consultados foram: ficha do protocolo, processo administrativo, EIA, Rima, complementações e parecer do Daia.

Para exame das deliberações do Consema, não foi necessária a consulta aos seus arquivos, uma vez que foram publicadas duas coletâneas, a primeira referente ao período compreendido entre os anos de 1983 e 1992 (SÃO PAULO, 1993) e a segunda relativa aos cinco anos seguintes (SEARA FILHO, 1998). 
Nos arquivos da Cetesb, foram consultados os processos de licenciamento e de contravenções, relatórios de inspeção e outros documentos. Para esta consulta, optou-se por apresentar autorização do proponente do projeto, evitando-se deste modo entraves burocráticos. Em apenas um dos casos estudados, por recusa de autorização do empreendedor, a consulta foi solicitada diretamente à agência regional da Cetesb.

A consulta aos arquivos do DEPRN também foi feita mediante autorização do proponente do projeto para evitar entraves burocráticos. No único caso não autorizado, não houve necessidade de consulta, pois não havia processo referente ao projeto no DEPRN.

Com relação ao Dusm, apesar de um dos casos selecionados para estudo estar inserido nos limites de jurisdição da Lei de Proteção aos Mananciais da Região Metropolitana de São Paulo, não havia processo referente ao empreendimento naquele departamento, razão pela qual seus arquivos não foram examinados.

A seguir, são descritos e comentados os principais documentos examinados.

\section{Ficha do protocolo do Daia}

Contém os dados de identificação do processo (número de registro e data de abertura); a razão social e o endereço do empreendedor; a localização (município) do empreendimento; o nome e o endereço da empresa consultora responsável pela elaboração do EIA e o registro de recebimento e envio de documentos relativos ao processo. Em alguns casos, além dos documentos que tramitaram até a aprovação do EIA, a ficha registra a entrega e encaminhamento de relatórios de monitoramento.

\section{Processo administrativo Daia}

Contém as diversas correspondências trocadas entre a SMA e o proponente ou outros órgãos consultados, tais como ofícios de encaminhamento de documentos técnicos, solicitações de complementação ou esclarecimentos, atas de reuniões, correspondências enviadas por parlamentares ou autoridades de governo à SMA manifestando apoio ao projeto ou solicitando agilidade na concessão das licenças ambientais, correspondências enviadas à SMA pelo Ministério Público solicitando informações sobre o processo etc. 


\section{$\boldsymbol{E I A}$}

Elaborado por empresa contratada pelo proponente, o EIA fornece informações detalhadas sobre o empreendimento proposto e área objetivada, além de avaliar os impactos ambientais positivos e negativos associados à implantação do projeto e propor medidas para mitigar ou compensar os impactos negativos. É um documento de conteúdo predominantemente técnico, preparado por equipe multidisciplinar e vem acompanhado de mapas, plantas, croquis, boletins de análise etc.

Apresentados em um ou dois volumes, com número de páginas variando de 41 a 233, os EIAs examinados não seguiram um padrão rígido para a organização dos itens e sua denominação. Com algumas variações, no entanto, foi possível identificar em todos eles os seguintes itens: caracterização do empreendimento, diagnóstico ambiental, impactos ambientais, medidas mitigadoras e plano de monitoramento.

O item referente à recuperação da área estava presente em apenas quatro dos casos estudados. Em um deles esta omissão era justificada por tratar-se de projeto destinado ao suprimento de pedras britadas para estrada em construção, prevendo-se que, mesmo após a conclusão da estrada, o empreendimento poderia ser reaberto, já que as reservas não estariam exauridas.

Em um dos casos estudados, não foi possível examinar o EIA e o Rima originais, bem como suas complementações, por terem sido devolvidos ao proponente em troca de novos documentos. O EIA examinado neste caso era o resultado de um processo de negociação entre o Daia e o proponente e consolidava os documentos originais e dois relatórios complementares solicitados. O resultado foi um EIA muito bem estruturado para a época, definindo claramente as fases de diagnóstico, identificação e avaliação de impactos, proposição de medidas mitigadoras, plano de monitoramento e plano de recuperação.

\section{Rima}

Assim como o EIA, o Rima é elaborado por empresa contratada pelo proponente e deve traduzir, para linguagem acessível ao público não-especializado, as conclusões do estudo. Nos casos estudados, no entanto, o Rima apresentado era apenas uma versão empobrecida do EIA, ou seja, suprimiam-se partes do texto, algumas tabelas, boletins de análises, figuras, mapas etc. O resultado era um documento mais compacto, mas sua linguagem não era, necessariamente, mais acessível ao público não-especializado. 


\section{Complementações}

Também de responsabilidade de empresa consultora contratada pelo proponente, o relatório complementar presta-se ao esclarecimento de dúvidas formuladas pelo Daia ou à apresentação de resultados de estudos complementares solicitados por aquele Departamento. Dentre os casos estudados, em apenas um não foram solicitadas complementações e, portanto, não houve relatório complementar.

Em outro dos casos, apesar de mencionado na ficha do protocolo e referido no processo administrativo, o relatório complementar não foi encontrado em nenhum dos arquivos examinados. Também não foi possível examinar o relatório complementar no caso já referido em que o EIA, o Rima e as complementações foram devolvidos ao proponente em troca de novos documentos. Nesse caso, foi examinado um relatório complementar solicitado após a apresentação da segunda versão do EIA e do Rima.

Nos cinco relatórios complementares examinados (em um dos casos havia dois relatórios), constatou-se a inexistência de padrão de organização para o documento, porém a tendência era a de adotar a mesma sequiência do pedido de complementação. Pode-se dizer que o relatório complementar é um documento de resposta e, como tal, junta discussão dos problemas, cálculos, reformulação de projeto ou de medidas ambientais, questionamento de exigências formuladas, esclarecimentos, proposição de novas medidas ambientais ou detalhamento das propostas formuladas no EIA. São apresentados textos, desenhos, mapas, resultados de ensaios e análises, documentos, fotos etc.

Os pedidos de complementação também não obedecem a um padrão de organização e tendem a transferir para o proponente todas as preocupações dos vários técnicos que examinaram o EIA, bem como as questões por eles formuladas. Em alguns casos, nota-se um esforço no sentido de direcionar os estudos de modo a sair do campo das declarações de intenção para o de assunção de compromissos ou mesmo apontar erros conceituais. Utilizam-se expressões como: "apontar concretamente as medidas...; apontar claramente quais são os procedimentos...; detalhar método e local para...; caracterização mapeada de...; apresentar análise de água dos seguintes parâmetros...; a empresa incluiu medidas mitigadoras no plano de monitoramento". Um dos pedidos de complementação examinados é quase um roteiro para elaboração de EIA, enquanto outro focaliza itens específicos, aprofundando a discussão sobre determinados temas. 
Apesar de introduzir alterações tanto no projeto como nas medidas mitigadoras, no plano de monitoramento e no plano de recuperação, em dois dos casos nos quais foi possível examinar os relatórios complementares, o proponente forneceu apenas uma cópia do documento, que ficou retida no Daia. Nos outros dois casos, foram entregues seis vias, tal como exigido na época para o EIA e o Rima.

\section{Parecer do Daia}

Traduz o resultado da análise efetuada pela equipe técnica do Daia e, além de conter uma síntese das informações fornecidas pelo proponente (nos vários documentos técnicos) ou obtidas em vistorias ou consultas a outros órgãos, recomenda a aprovação do projeto e sugere medidas ambientais complementares às propostas pelo empreendedor.

Com número de páginas variando de 9 a 18, em todos os casos estudados, com pequenas variações, o parecer do Daia é organizado nos seguintes itens: introdução, caracterização do empreendimento, diagnóstico ambiental, impactos ambientais, medidas mitigadoras, plano de recuperação, monitoramento e conclusões. Em um dos casos, o parecer traz ainda anexos extraídos do EIA ou suas complementações.

\section{Deliberação do Consema}

As deliberações do Consema registram as decisões tomadas pelos conselheiros, podendo acrescentar, na forma de exigências, novos condicionantes à aprovação do projeto. São documentos concisos, em linguagem padronizada, que aprovam o EIA/Rima com base no parecer do Daia e obrigam o empreendedor a cumprir, além das medidas mitigadoras propostas no EIA, exigências que relaciona.

Em dois dos casos estudados, no entanto, a deliberação do Consema não afirma a obrigação de cumprir as medidas mitigadoras propostas no EIA, limitando-se a aprová-lo com base no parecer do Daia e fixar exigências. Em um dos casos, o Consema obriga o empreendedor a cumprir apenas as medidas mitigadoras e exigências contidas no parecer do Daia, além de fixar novas exigências.

\section{Processos Cetesb}

O principal é o processo de licenciamento, que contém sempre um Memorial de Caracterização do Empreendimento (MCE), no qual são registradas, em formulário padrão, as principais características do projeto, tais como área objeto do pedido de 
licença, horário de funcionamento, produtos e rejeitos, quantidades produzidas, efluentes líquidos e resíduos sólidos etc. Além disso, são registrados os vários contatos entre a Cetesb, o solicitante da licença e os diversos órgãos do sistema, em especial o Daia, DEPRN e Consema; pareceres técnicos, relatórios complementares, a licença de instalação e a licença de funcionamento.

Para cada solicitação de licença de ampliação do empreendimento é aberto um novo processo. Sob a denominação de ampliação, a Cetesb inclui as ampliações propriamente ditas, de área ou de quantidades produzidas, e as alterações de processo ou a aquisição de novos equipamentos.

Em outros processos ou pastas, a Cetesb registra as contravenções e os autos de inspeção, além de documentos variados como registros de reclamações da população, processos da antiga Secretaria dos Negócios Metropolitanos, laudos de vistoria do DEPRN e relatórios de acompanhamento encaminhados pelo empreendedor em atendimento a exigências do processo de AIA, entre outros.

Os procedimentos variam entre as regionais da Cetesb, e a localização de todos os registros referentes a cada empreendimento requer uma pesquisa nos arquivos, que às vezes é dificultada por alterações na razão social do empreendedor ou pelaexistência de vários projetos da mesma empresa no município. A título de ilustração, destaca-se que em um dos casos estudados a atuação da Cetesb encontrava-se registrada em numerosos documentos organizados em 18 pastas, sendo nove referentes a processos de licenciamento, um processo de imposição de penalidade e oito pastas administrativas de controle.

\section{Processos DEPRN}

Os processos DEPRN tratam de autorizações para supressão de vegetação e intervenções em áreas de preservação permanente, com ou sem supressão de vegetação. Registram as solicitações, os laudos de vistoria, trocas de despachos entre as várias equipes técnicas do órgão, contatos com o Ibama e com a Cetesb.

\subsection{A cronologia do processo}

Conforme relatado no capítulo anterior, o tempo médio de análise dos EIAs aprovados até o ano de 1997 foi de 22,2 meses. Embora os primeiros estudos aprovados tenham tido tramitação mais breve, a partir de 1992 esse tempo cresceu, tendo chegado a quase 5 anos em 1995. Nos anos seguintes, recuou um pouco, mas manteve-se 
superior a 3 anos. A análise dos seis casos revelou detalhes dos trâmites e possibilitou melhor compreensão dos fatores que contribuíram para esse quadro.

Além dos prazos de tramitação dos EIAs, desde sua apresentação à SMA até sua aprovação, foram analisados os tempos requeridos para a emissão das licenças de instalação e funcionamento. Os resultados são resumidos na Tabela 5.1 e no gráfico da Figura 5.1, a seguir.

Tabela 5.1: Cronologia do processo

\begin{tabular}{|c|c|c|c|c|}
\hline \multirow{2}{*}{ CASO } & \multicolumn{4}{|c|}{ PRAZO (em meses) } \\
\cline { 2 - 5 } & $\begin{array}{c}\text { Aprovação do } \\
\text { EIA }\end{array}$ & Emissão da LI & Emissão da LF & TOTAL \\
\hline $\mathbf{1}$ & 19 & 18 & 5 & 42 \\
\hline $\mathbf{2}$ & 16 & 2 & 88 & 106 \\
\hline $\mathbf{3}$ & 14 & 2 & 36 & 52 \\
\hline $\mathbf{4}$ & 14 & 15 & 56 & 85 \\
\hline $\mathbf{5}$ & 7 & 2 & 18 & 27 \\
\hline $\mathbf{6}$ & 13 & 9 & $100^{*}$ & $122^{*}$ \\
\hline
\end{tabular}

* Neste caso, como a LF ainda não havia sido concedida por ocasião da pesquisa, o tempo registrado corresponde ao decorrido até a emissão de um parecer técnico favorável a sua concessão.

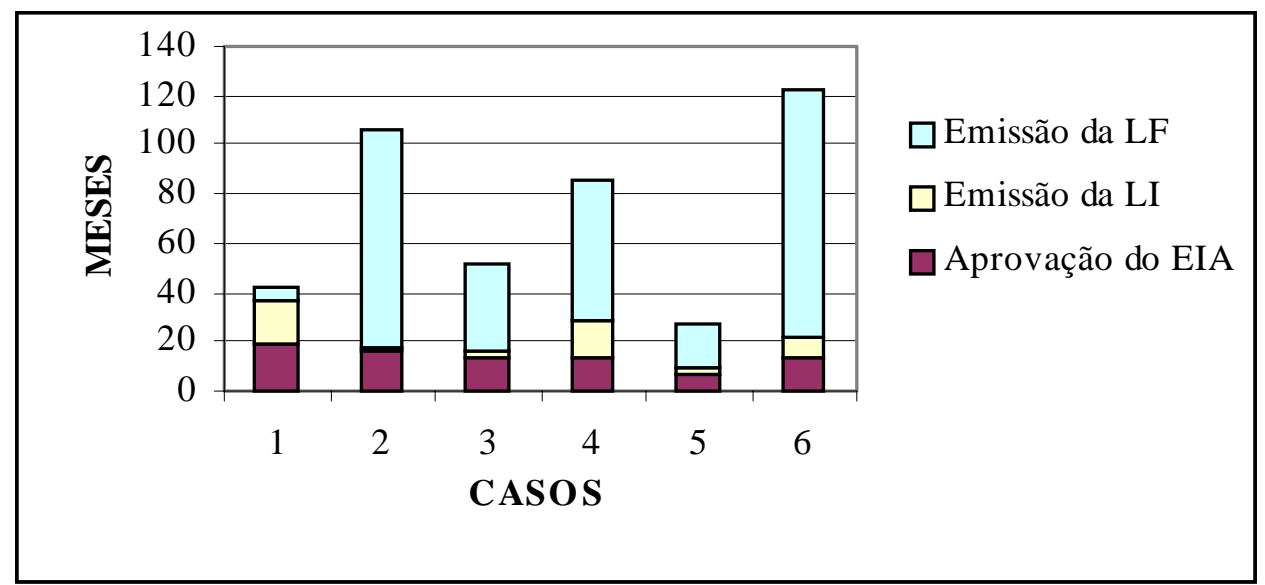

\section{Figura 5.1: Cronologia do processo}

Como se observa, o prazo total para a obtenção da licença de funcionamento variou, nos casos estudados, de 27 a 122 meses, sendo que, para a aprovação do EIA foram consumidos de 7 a 19 meses.

Com relação ao prazo para aprovação do EIA, para facilitar a comparação, adotou-se como marco zero do processo a apresentação do EIA à SMA, embora em alguns casos o início dos trâmites tenha sido anterior a esse momento. O tempo consumido nas etapas iniciais variou de zero a dois meses em cinco dos casos 
estudados, mas chegou a 19 meses em um deles. Neste caso, aproximadamente 11 meses foram utilizados pelo proponente do projeto para a elaboração do EIA.

O tempo decorrido entre a apresentação do EIA à SMA e sua aprovação pelo Consema foi consumido, nos vários casos, em análises por equipes do Daia; consultas a outros órgãos do sistema, incluindo a Cetesb e o DEPRN; vistorias; reuniões com o proponente; solicitação de informações complementares; elaboração de relatórios complementares; elaboração de pareceres do Daia e tramitação no Consema. Em parte desse tempo, o controle do andamento do processo esteve a cargo do proponente, particularmente na elaboração de estudos complementares solicitados, mas, de modo geral, os tempos consumidos pelos órgãos ambientais superaram largamente os despendidos pelo empreendedor. O Quadro 5.2 mostra em detalhe a distribuição do tempo de análise entre proponente e órgão ambiental.

\begin{tabular}{|c|c|c|c|}
\hline \multirow{2}{*}{ CASO } & \multicolumn{3}{|c|}{ PRAZO (em meses) } \\
\cline { 2 - 4 } & Aprovação do EIA & Proponente & Órgãos ambientais \\
\hline $\mathbf{1}$ & 19 & 3 & 16 \\
\hline $\mathbf{2}$ & 16 & 2 & 14 \\
\hline $\mathbf{3}$ & 14 & 5 & 9 \\
\hline $\mathbf{4}$ & 14 & 9 & 5 \\
\hline $\mathbf{5}$ & 7 & 3 & 4 \\
\hline $\mathbf{6}$ & 13 & 0 & 13 \\
\hline
\end{tabular}

\section{Quadro 5.2: Prazos para aprovação do EIA $\square$}

Com relação aos prazos para a emissão das licenças de instalação e de funcionamento, não foi possível distinguir com precisão os períodos nos quais o andamento do processo dependeu exclusivamente dos órgãos ambientais, daqueles consumidos pelo empreendedor no cumprimento de suas obrigações. Esta dificuldade deveu-se principalmente à imprecisão dos registros — reuniões e solicitações nem sempre documentadas - e ao espaçamento excessivo entre as vistorias da Cetesb, que impossibilitou a definição do períodos nos quais o empreendimento funcionava regularmente. Em alguns períodos, ou o empreendedor tinha pendências em relação às suas obrigações, ou a Cetesb deixava de vistoriar o empreendimento e a situação real não era registrada no processo. O Quadro 5.3 resume os prazos totais para a emissão das

\footnotetext{
${ }^{30}$ Refere-se ao tempo médio de análise dos EIAs aprovados no mesmo ano do caso em estudo, conforme dados apresentados no capítulo anterior (Tabela 4.6).
} 
licenças de instalação e de funcionamento, assim como sua distribuição aproximada entre o proponente e os órgãos ambientais.

\begin{tabular}{|c|c|c|c|}
\hline \multirow{2}{*}{ CASO } & \multicolumn{3}{|c|}{ PRAZO (em meses) } \\
\cline { 2 - 4 } & Emissão da LI e LF & Proponente & Órgãos ambientais \\
\hline $\mathbf{1}$ & 23 & 5 & 18 \\
\hline $\mathbf{2}$ & 90 & 87 & 3 \\
\hline $\mathbf{3}$ & 38 & 21 & 17 \\
\hline $\mathbf{4}$ & 71 & 48 & 23 \\
\hline $\mathbf{5}$ & 20 & 20 & 0 \\
\hline $\mathbf{6}$ & 109 & 89 & 20 \\
\hline
\end{tabular}

Quadro 5.3: Prazos para a emissão das licenças de instalação e de funcionamento

Ao contrário dos prazos para aprovação do EIA, estes foram predominantemente de responsabilidade do proponente. Os longos períodos decorridos entre a aprovação do EIA pelo Consema e a emissão da licença de funcionamento devem-se, principalmente aos seguintes fatores:

1. Maior rigor na formulação das exigências para a obtenção das licenças, em parte devido ao processo de AIA.

2. Necessidade de ajustes e reformulação das exigências oriundas do processo de AIA, de modo a torná-las mais precisas e exeqüíveis.

3. Complacência ou omissão por parte da Cetesb, permitindo o funcionamento de empreendimentos sem as licenças devidas.

4. Atitude reativa por parte do empreendedor, que somente implementava as medidas mitigadoras fixadas no processo de AIA quando notificado ou ameaçado de multa ou paralisação de atividades.

5. Desarticulação entre os vários órgãos ambientais envolvidos no processo de licenciamento.

O gráfico da Figura 5.2 representa o cômputo geral dos tempos despendidos pelo proponente e pelos órgãos ambientais desde a apresentação do EIA à SMA até a obtenção da licença de funcionamento. Merece destaque a constatação de que a maior parte desse tempo foi consumida pelo proponente na elaboração e complementação dos estudos ambientais e na implementação das medidas definidas no processo de AIA.

\footnotetext{
${ }^{31}$ No caso 6, como a LF ainda não havia sido concedida por ocasião da pesquisa, o tempo registrado corresponde ao decorrido até a emissão de um parecer técnico favorável a sua concessão.
} 


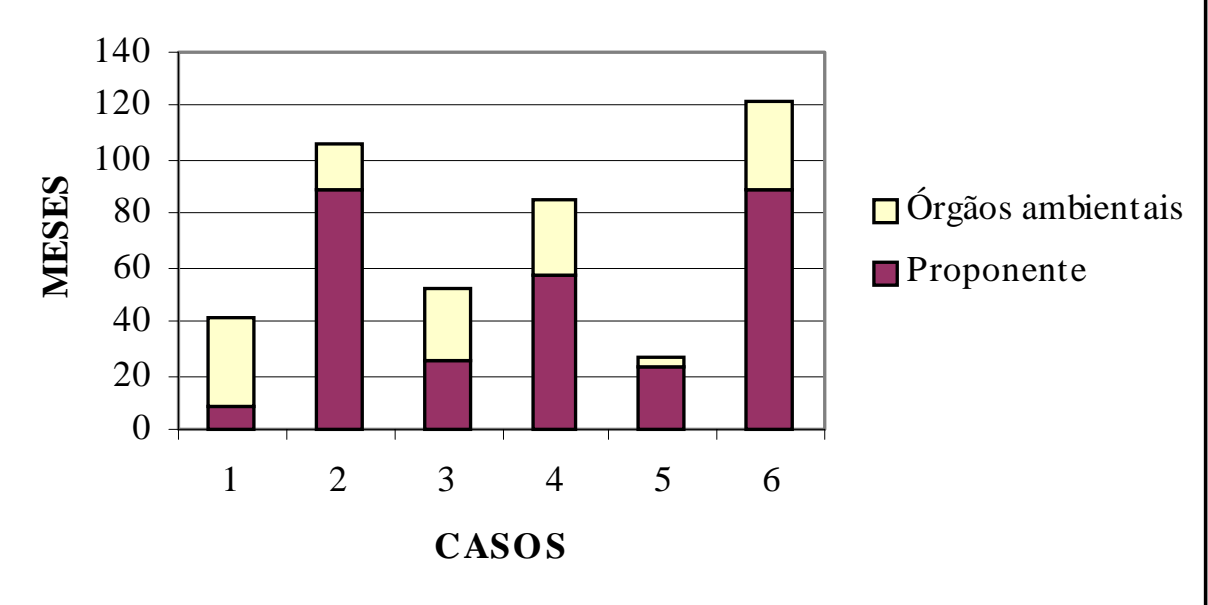

Figura 5.2: Distribuição geral dos prazos de aprovação de EIA e emissão das licenças ambientais.

\subsection{Condicionantes à aprovação do projeto}

A licença prévia, implícita na aprovação do EIA, é condicionada ao cumprimento das medidas ambientais propostas no estudo de impacto ambiental e das exigências formuladas pelo Consema. Além disso, é lícito supor que o projeto aprovado é o descrito no EIA e em outros documentos que o complementam. Nesta pesquisa, procurou-se resgatar estas informações dos documentos examinados e analisar aspectos que pudessem comprometer a eficácia da etapa de acompanhamento do processo de AIA. Procurou-se observar, especialmente, a evolução dos entendimentos, o fluxo de informações e a precisão na formulação das medidas ambientais.

Em cada um dos documentos examinados, foram pesquisadas principalmente as características do projeto e as medidas mitigadoras, de monitoramento e de recuperação propostas. Estas medidas foram analisadas quanto a sua localização no documento e quanto à precisão de sua formulação.

A localização no documento é importante, pois está estreitamente relacionada com o fluxo de informações, ou seja, o acesso à descrição da medida ambiental por parte dos técnicos encarregados da fiscalização depende do item do documento no qual a medida é apresentada. Esta relação já era presumida desde o início das pesquisas e foi confirmada no decorrer de sua realização, como ficará demonstrado nos próximos itens.

Com relação à precisão de linguagem com que as medidas ambientais são formuladas, considerou-se que esta depende do seu nível de detalhamento e dimensionamento, ou seja, da fixação de limites quantitativos ou semiquantitativos para 
parâmetros selecionados. Vale lembrar que o detalhamento e dimensionamento das medidas ambientais contribuem para facilitar sua fiscalização, reduzindo a necessidade de avaliações subjetivas por parte dos fiscais. Em certos níveis, no entanto, o alto grau de detalhamento e o dimensionamento das medidas ambientais podem não ser apropriados para a fiscalização, uma vez que sua verificação requereria a presença do agente fiscal no momento da execução dos trabalhos. Em última análise, dependendo de sua formulação, procurou-se classificar as medidas ambientais em fiscalizáveis e nãofiscalizáveis.

\subsubsection{Medidas propostas no EIA}

O número total de medidas propostas no EIA variou de 17 a 63 conforme o caso estudado. De modo geral, as medidas foram apresentadas nos itens medidas mitigadoras, monitoramento ou recuperação da área, embora freqüentemente este enquadramento não correspondesse ao seu conteúdo. Assim, muitas medidas apresentadas no item medidas mitigadoras eram, na realidade, medidas de monitoramento ou de recuperação de área, o mesmo se observando em outros itens.

O exame completo dos documentos revelou ainda várias medidas de caráter ambiental formuladas em outros itens, particularmente na caracterização do empreendimento. A maior parte destas medidas foi reapresentada no item apropriado, porém nem sempre com o mesmo nível de detalhe. A Tabela 5.2 mostra o número e a distribuição das medidas propostas em cada caso.

Tabela 5.2: Medidas propostas no EIA e sua localização no documento

\begin{tabular}{l|c|c|c|c|c|c}
\hline \multicolumn{1}{c|}{ ITEM } & Caso 1 & Caso 2 & Caso 3 & Caso 4 & Caso 5 & Caso 6 \\
\hline $\begin{array}{l}\text { Caracterização do empreendi- } \\
\text { mento e outros itens }\end{array}$ & 6 & 23 & 8 & 1 & 38 & 10 \\
\hline Medidas mitigadoras & 13 & 9 & 17 & 3 & 20 & 11 \\
\hline Monitoramento & 3 & 3 & 9 & 0 & 5 & 1 \\
\hline Recuperação da área & 5 & 8 & 1 & 13 & 0 & 0 \\
\hline \multicolumn{1}{c}{ TOTAL } & 27 & 43 & 35 & 17 & 63 & 22 \\
\hline
\end{tabular}

Com relação ao aspecto precisão de linguagem, observou-se que a maior parte das proposições eram formuladas em linguagem vaga e imprecisa e muitas não poderiam sequer ser classificadas como medidas ambientais, uma vez que se limitavam a expor critérios de projeto, declarações de intenção genéricas ou mesmo destacar aspectos positivos do empreendimento. Alguns exemplos de afirmações com estas 
características, extraídos dos EIAs analisados, dos itens medidas mitigadoras, monitoramento ou recuperação de áreas, são apresentados a seguir:

1. "Conduzir os trabalhos de lavra distante de áreas habitadas".

2. "Utilização, sempre que possível, de mão-de-obra local".

3. "Reabilitar as áreas mineradas".

4. "Verificar se os trabalhos de lavra e de reabilitação estão sendo executados dentro de suas respectivas programações".

5. "Não serão afetadas as matas ciliares que se encontram nas imediações do projeto".

6. "Disposição dos bota-fora de modo a não interferirem com a rede de drenagem".

7. "Não interferência com a mata de preservação permanente e sua preservação nos entornos do empreendimento".

8. "Deverá se proceder ao plantio de árvores nas vias de acesso".

9. "Manutenção de canaletas de drenagem".

10. "Limpeza da bacia de decantação".

11. "Manutenção das bermas e taludes pela recomposição vegetal e retaludamento".

12. "Acompanhamento e readaptação das espécies plantadas".

13. "Os ruídos dos equipamentos de processo de beneficiamento .... não serão de grande impacto, porque estarão dentro de construções de paredes espessas".

14. "Evitar a erosão como medida contra o assoreamento".

15. "Boa regulagem dos motores de modo a reduzir a emissão de material sólido e de ruídos".

16. "Evitar dragar próximo às margens".

17. "Não liberar muitas partículas durante a operação de dragagem, evitando assim contribuir para o aumento da turbidez".

18. "Seções batimétricas e análises granulométricas regulares".

19. "Não dragar em um só trecho para que não ocorra desestabilização das laterais".

20. "Cerca de $95 \%$ da mão-de-obra virá da região".

21. "Colocação de alevinos nos lagos após o período de secamento dos mesmos".

22. "Manutenção da área por funcionários".

23. "Os cortes e aterros serão executados de modo cauteloso, sem deixar o solo exposto por muito tempo".

Uma pequena parcela das medidas propostas nos EIAs era dimensionada ou apresentava descrição detalhada das ações e procedimentos propostos. O fato de uma medida estar dimensionada não garante a viabilidade de sua fiscalização, embora facilite a implantação do empreendimento de acordo com o projeto. A descrição detalhada, quando presente, freqüentemente estava incluída no item caracterização do empreendimento (ou outros) e reapresentada de forma resumida em um dos itens reservados para medidas ambientais. Exemplos desta condição são apresentados a seguir:

1. No item medidas mitigatórias, a medida proposta é: "o estéril deverá ser estocado convenientemente para futuro aproveitamento na remodelação da cava e também o solo orgânico ou vegetal, conforme as normas já citadas no item caracterização do empreendimento". No item referido, nada menos do que 12 propostas tratam do assunto, o estéril é subdividido em solo vegetal e solo estéril e os procedimentos são discutidos em detalhe. 
2. No item medidas mitigadoras, tem-se: "as lagoas de decantação deverão ter seu fundo e paredes impermeabilizadas, conforme já descrito no item caracterização do empreendimento". Neste item, a formulação é a seguinte: "o fundo das lagoas de decantação deverá ser impermeabilizado com argila compactada com $5 \mathrm{~cm}$ de espessura, com manta plástica, ou de poliéster, ou ainda com camada asfáltica. Tal impermeabilização é fundamental em vista do terreno subjacente às lagoas ser extremamente poroso e com alta permeabilidade".

3. Com a frase "todos os efluentes resultantes do processo de lavra, tratamento ou de serviços auxiliares serão conduzidos à lagoa de decantação, tanques neutralizadores ou fossas sépticas antes de serem reciclados ou enviados ao córrego (conforme especificado no item caracterização do empreendimento)" foram resumidas pelo menos onze propostas sobre o assunto, que descrevem todo o sistema de drenagem das águas pluviais nas áreas de lavra, beneficiamento e auxiliares, o tratamento de efluentes do beneficiamento em um conjunto de lagoas de decantação, a separação de óleos e graxas das áreas de oficinas e o tratamento dos efluentes sanitários.

Nem sempre o detalhamento encontrava-se em outro item. Dentro do próprio item medidas mitigadoras, por exemplo, foi apresentada um proposta que tratava do plantio de espécies regionais para servir de banco de sementes e explicava os vários mecanismos de dispersão esperados (por exemplo: quiropterocórico, descrito como disseminação feita por morcegos) que agilizariam o repovoamento florestal. Ou seja, além de confundir a apresentação da medida mitigadora com a discussão dos seus objetivos, tenta descrever o processo, o que resulta em um texto didático, de várias páginas, abordando fundamentos teóricos.

Foram encontradas ainda propostas muito detalhadas, definindo não somente o equipamento e local de implantação, como os procedimentos de operação. Tal detalhamento, embora apropriado para um documento técnico elaborado para servir como guia da implementação do projeto, é inadequado para a fiscalização, uma vez que seu acompanhamento exigiria a presença do agente fiscal no momento da execução dos trabalhos. É o caso de detalhamento de projetos de recuperação com especificação de tipos de peixes, espécies arbóreas, técnicas de adubação e plantio etc. São exemplos dessa condição:

1. Proposta que estabelece largura de bermas, altura e ângulo de inclinação de taludes e dos furos para desmonte, material e espessura adotados para o tamponamento dos furos, especificação de retardos e procedimentos para a cobertura do cordel detonante.

2. "Construção de coletores de sedimentos para os finos abatidos no processo de britagem. Tanque revestido com gabiões dentro da área de britagem com volume de $300 \mathrm{~m}^{3}$, que recebe as águas superficiais do pátio e pilha de produtos. Quando o tanque estiver 50\% assoreado, remover o material com escavadeira, deixar secar e depositar no bota-fora. A água acumulada no coletor é utilizada na lavagem de brita".

3. "No início da operação da pedreira, medir os níveis de vibrações, impacto de ar e velocidade de partículas a 500 e 1000 metros da frente de lavra, utilizando sismógrafo marca SINCO, modelo S-3 ou similar. Caracterizar a carga utilizada no desmonte, as condições meteorológicas do dia e as condições geológicas do ponto de captação. A cada seis meses novo ensaio deve ser efetuado nos mesmos locais".

4. "Os furos deverão ser iniciados com espoleta de retardo Mantinel". 
5. "Não efetuar detonações quando ocorrerem fortes ventos com velocidades superiores a $15 \mathrm{~km} / \mathrm{h}$ ”.

Outro tipo de situação observada na formulação das medidas ambientais foram as medidas que extrapolavam a competência do proponente. São exemplos desta condição:

1. Medida de monitoramento, que dependia de um convênio a ser firmado com a própria Cetesb para a medição e avaliação da poluição do ar. Eram definidos o método, o equipamento, os pontos de amostragem e a periodicidade da coleta.

2. "Proibição de transformação da área em depósito de lixo doméstico e industrial, devido às suas características de várzea de rio".

3. "Cascalhamento e aplainamento da estrada a ser realizados pelos proprietários do porto e/ou pela Prefeitura".

Várias das medidas propostas nos EIAs, além de precárias quanto à qualidade da formulação tratavam de questões ligadas à saúde e segurança do trabalhador, extrapolando a competência dos órgãos de fiscalização vinculados à Secretaria do Meio Ambiente. São exemplos:

1. “Os operários na frente de lavra e área de britagem deverão usar máscaras de poeira com filtros que coletem no mínimo $90 \%$ da poeira fina”.

2. "Os operadores de equipamentos deverão usar fones de ouvido".

3. “Antes de cada detonação a mineradora deverá estabelecer um perímetro de segurança em relação à área de detonação".

4. "Os operários que necessitarem trabalhar dentro de ambientes com grande intensidade sonora deverão usar protetores auriculares".

5. "Incentivo permanente aos cuidados relativos à higiene e segurança do trabalho através da Cipa".

Foram observadas ainda "medidas mitigatórias" que propunham a execução de estudos complementares, como análise de solo para fins de monitoramento ou a medição da intensidade sonora a diversas distâncias dos equipamentos para determinar em quais áreas da indústria os operários deveriam utilizar protetores auriculares.

Finalmente, merece destaque pelo seu ineditismo e ausência de fundamento técnico, uma proposta surpreendente encontrada em um dos casos estudados: "Já desativada a cava, esta deverá permanecer seca por dois meses para que seja exposta ao sol, pois funcionará como antisséptico, isto é, o sol se encarregará de acabar com organismos indesejáveis".

No cômputo geral, eliminando-se as repetições, já que muitas vezes a mesma medida é apresentada mais de uma vez, com pequenas variações de formulação, em diversos itens do EIA, o número de medidas propostas variou de 17 a 24, totalizando 122 medidas nos seis casos estudados. Quanto à exeqüibilidade de fiscalização, as medidas distribuíram-se em: 34\% (41 medidas) fiscalizáveis, 19\% (23 medidas) não 
fiscalizáveis e 48\% fiscalizáveis, porém requerendo interpretação e avaliações subjetivas por parte dos agentes de fiscalização e, conseqüentemente, sujeitas a controvérsias e contestações. A Tabela 5.3 resume o cômputo geral das medidas propostas no EIA e sua classificação quanto à formulação para cada caso estudado.

Tabela 5.3: Medidas propostas no EIA e sua classificação quanto à formulação

\begin{tabular}{l|c|c|c|c|c|c|c}
\hline \multicolumn{1}{c|}{ CLASSIFICAÇÃO } & Caso 1 & Caso 2 & Caso 3 & Caso 4 & Caso 5 & Caso 6 & Total \\
\hline Fiscalizável & 9 & 4 & 13 & 4 & 8 & 3 & 41 \\
\hline Não-fiscalizável & 9 & 3 & 2 & 4 & 5 & 0 & 23 \\
\hline Parcialmente fiscalizável & 3 & 12 & 7 & 9 & 11 & 16 & 58 \\
\hline \multicolumn{1}{c}{ TOTAL } & 21 & 19 & 22 & 17 & 24 & 19 & 122 \\
\hline
\end{tabular}

\subsubsection{Medidas propostas no Rima}

As medidas ambientais propostas no Rima tinham, em sua maioria, formulação idêntica à do EIA. Em alguns casos, no entanto, houve supressão de parágrafos nos quais os procedimentos eram mais bem detalhados e em outros a formulação das propostas, já vaga e imprecisa, ficou ainda mais confusa, misturando a apresentação da proposta com a discussão do impacto. São exemplos desta condição:

1. "Para os problemas de ruído e pó nas operações de carregamento e transporte de material, a aspersão de água no percurso contorna parcialmente o problema".

2. “Colocação de bicos aspersores na unidade de britagem diminui sensivelmente a emissão de material particulado".

Em apenas um dos casos estudados, no entanto, foram observadas diferenças consideráveis com relação às propostas apresentadas no EIA: duas propostas foram retiradas e cinco outras foram acrescentadas ou apresentadas com formulação diferente.

Considerando-se que o Rima destina-se a um público não especializado e que as equipes técnicas do órgão ambiental utilizam em geral o EIA, tido como mais completo e tecnicamente mais preciso para fundamentar sua análise e atuação, as propostas apresentadas somente no Rima podem exercer influência no processo de decisão e ficar de fora da etapa de acompanhamento.

\subsubsection{Medidas propostas no relatório complementar}

O número total de medidas propostas nos relatórios complementares variou de 9 a 38 nos quatro casos em que foi possível examinar este documento. Apesar de intitulados complementares, três dos relatórios examinados apresentavam conteúdo nitidamente substitutivo, abordando todos os aspectos já discutidos no EIA e reapresentando, modificadas ou não, as medidas ali propostas, além de formular novas. 
Com relação à formulação das medidas mitigadoras, de monitoramento ou de recuperação, persistiram vários dos problemas observados nos EIAs, tais como linguagem vaga e imprecisa, declarações de intenção ou critérios de projeto apresentados como medidas mitigadoras, propostas genéricas etc. São exemplos de medidas ambientais propostas nos relatórios complementares:

1. "Privilegiar o desmonte das frentes de lavra mais instáveis".

2. "Reduzir a infiltração de água precipitada e promover a drenagem de água de superfície para prevenir escorregamentos mais extensos ou envolvendo maiores volumes do que os esperados na extração, especialmente em época de chuvas".

3. "Evitar perdas de água para os mananciais e para o solo através da operação das bacias de decantação".

4. “Acompanhamento do desempenho com eventual correção das medidas mitigadoras implantadas".

5. "Não será feita dragagem próximo às lagoas marginais".

Observaram-se, ainda, problemas relacionados à localização das informações no documento, tais como medidas dimensionadas ou detalhadas em itens reservados à caracterização do empreendimento, apresentadas juntamente com cálculos e discussão do problema e apenas citadas nos itens relativos a medidas ambientais. Além disso, ocorreram divergências entre as formulações de uma mesma medida em itens distintos do documento. Como exemplo, cita-se a localização do depósito de armazenagem de combustíveis a "60 metros da margem do rio" em um trecho do relatório e apenas "afastado da margem do rio, fora do alcance das enchentes" no tópico relativo às medidas mitigadoras. No caso da pilha de estocagem, a localização preconizada era a "45 metros da margem" no item de caracterização do empreendimento e a "30 metros" em um item relativo a medidas de recuperação imediata.

Por tratar-se de documento de resposta, muitas medidas foram apresentadas com alto nível de detalhe, com definição de procedimentos, especificação de equipamentos e insumos. Eram textos adequados como guia para a implementação das medidas, porém seu acompanhamento por parte da fiscalização seria difícil por exigir a presença do fiscal durante os trabalhos. Foi o caso de procedimentos descritos para a construção de pilhas de estéril, em várias etapas, começando pela limpeza do terreno até a compactação do material em camadas e definição do ângulo máximo dos taludes. Estas medidas, embora não fiscalizáveis, podem ser auditáveis se houver procedimentos apropriados, como por exemplo, documentação fotográfica da construção da pilha, registro de movimentação de estéreis etc. 
No cômputo geral, eliminando-se as repetições, o número de medidas variou de 9 a 35, totalizando 86 medidas nos quatro casos examinados. Destas, 14\% (12 medidas) foram classificadas como fiscalizáveis, 26\% (22 medidas) não-fiscalizáveis e 60\% (52 medidas) fiscalizáveis, porém requerendo interpretação e avaliações subjetivas por parte dos agentes de fiscalização. A Tabela 5.4 resume o cômputo geral das medidas propostas no relatório complementar e sua classificação quanto à formulação para os casos examinados.

Tabela 5.4: Medidas propostas no relatório complementar e sua classificação quanto à formulação

\begin{tabular}{l|c|c|c|c|c|c|c}
\hline \multicolumn{1}{c|}{ CLASSIFICAÇÃO } & Caso 1 & Caso 2 & Caso 3 & Caso 4 & Caso 5 & Caso 6 & Total \\
\hline Fiscalizável & 1 & 6 & 0 & 5 & ND & ND & 12 \\
\hline Não-fiscalizável & 15 & 4 & 0 & 3 & ND & ND & 22 \\
\hline Parcialmente fiscalizável & 19 & 13 & 9 & 11 & ND & ND & 52 \\
\hline \multicolumn{1}{c}{ TOTAL } & 35 & 23 & 9 & 19 & ND & ND & 86 \\
\hline
\end{tabular}

ND: não-disponível. Nesses casos, o relatório complementar não foi elaborado ou não foi encontrado

\subsubsection{Medidas registradas no parecer do Daia}

O parecer do Daia é o registro da análise efetuada pela equipe técnica multidisciplinar e de suas conclusões a respeito da viabilidade ambiental do empreendimento proposto. Além de apresentar um resumo da caracterização do empreendimento, do diagnóstico ambiental da área e dos impactos ambientais previstos, procura reproduzir ordenadamente as medidas mitigadoras, de monitoramento e de recuperação de área formuladas pelo empreendedor no EIA e em suas complementações. O parecer propõe, ainda, sob a designação de exigências, novas medidas ambientais como condicionantes à aprovação do projeto.

Com relação ao primeiro grupo de medidas, cuja origem são os documentos elaborados pelo proponente, procurou-se observar se todas as propostas formuladas pelo empreendedor foram reproduzidas integralmente e corretamente no parecer. De modo geral, constatou-se que, em maior ou menor intensidade, conforme o caso estudado, ocorreram falhas na transmissão destas informações. Em alguns casos houve omissão, total ou parcial, de medidas; em outros, distorção do seu conteúdo; e, em outros ainda, o Daia acrescentou detalhes ou mesmo medidas sem esclarecer que se tratava de exigências.

A omissão de informações está quase sempre presente, uma vez que, ao resumir a proposta, o Daia suprime detalhes de dimensionamento de equipamentos e instalações 
ou definição de procedimentos. Assim, mesmo as poucas medidas apresentadas com detalhe nos documentos do proponente, são reproduzidas de modo impreciso no parecer do Daia, ou seja, o resumo empobrece o texto, reduzindo muitas vezes o alcance da proposta. Em vários casos, o texto do parecer faz menção a detalhes da proposta presentes no EIA, nas complementações ou em determinados mapas ou plantas, ou seja, o conhecimento integral da proposta dependeria da consulta a toda a documentação. A título de ilustração, vale destacar o seguinte trecho encontrado em um dos pareceres: "O estudo aponta uma série de medidas que deverão ser implementadas a fim de minimizar a ação impactante do empreendimento sobre o meio ambiente. Na sua maioria, são genéricas, de difícil fiscalização, mas essa deficiência é compensada no Plano de Recuperação e Monitoramento". Ocorre que tal documento não se encontrava apensado a nenhum dos processos consultados e, tampouco existia registro de sua apresentação a qualquer dos órgãos do sistema. A seguir, são apresentados e comentados casos de omissão total ou parcial de medidas contidas nos documentos elaborados pelo proponente:

1. Com relação aos horários das detonações de explosivos, a determinação formulada no EIA e complementações era de que "estes horários deverão ser amplamente divulgados a todos os funcionários e comunidade vizinha". No parecer do Daia ficou reduzida a "...... em horários predeterminados e conhecidos dos funcionários", ou seja, a comunidade vizinha foi excluída.

2. A construção de coletores de sedimentos, já comentada no item relativo às medidas propostas no EIA, por seu alto nível de detalhe ficou reduzida, no parecer do Daia, a "construção de coletores de sedimentos para os finos abatidos no processo de britagem e de material carreado pelas águas pluviais, que serão reciclados em circuito fechado". Deixou-se de mencionar os materiais de construção, as dimensões dos coletores e os procedimentos para sua operação.

3. Em outra medida, a redação dada pelo Daia elimina a especificação de marca e modelo de sismógrafo, optando por uma descrição genérica do equipamento: “... sismógrafo com duas estações, uma para o geofone de vibração e outra para o sensor de impacto de ar ...”. Esta abordagem, no entanto, não prevaleceu no caso do sistema de inicialização da detonação, para o qual o Daia manteve a formulação "utilização de espoleta de retardo Mantinel".

4. Em um dos casos estudados, nada menos do que nove das propostas apresentadas no texto de complementações não foram reproduzidas no parecer do Daia. Neste mesmo caso, no entanto, uma das exigências formuladas estabelecia que o empreendedor deveria executar "as medidas mitigadoras apresentadas no EIA/Rima e complementações", revelando que o texto do parecer não esgotava o assunto. 
Em alguns dos pareceres examinados, a tentativa de resumir as propostas formuladas pelo empreendedor é desastrada e resulta em textos confusos, juntando vários assuntos em uma única formulação, transcrições com erros e modificação do sentido da proposta. São exemplos desta condição:

1. "Os impactos gerados pelo decapeamento da jazida e disposição do estéril e solo vegetal serão em leiras drenadas, estabilizadas e contidas visando remodelação futura da lavra”.

2. “As águas pluviais da área do beneficiamento serão encaminhadas para as lagoas de decantação". No EIA previa-se que estas águas iriam para a lagoa de água limpa.

3. “A área de lavra deverá ser dotada de sistema de drenagem para direcionamento das águas fluviais (sic).....".

4. "Os impactos gerados pelo tratamento dos efluentes serão mitigados através da impermeabilização das lagoas e reaproveitamento das águas em circuito fechado".

5. "Os efeitos do ruído nos locais de maior incidência serão mitigados com o uso de protetores circulares (sic)".

6. Enquanto o EIA previa a "colocação de aspersores na unidade de britagem, diminuindo sensivelmente a emissão de material particulado", o parecer do Daia preconizava que "durante o beneficiamento, o desprendimento de poeiras será reduzido com a aspersão de água através de sistema apropriado de filtros de ar ligados ao britador".

7. A linguagem adotada nos pareceres é, em certos trechos, confusa e rebuscada: "o plano de fogo prevê cargas de espera aptas a não induzir vibrações superimpostas de maneira sobreposta no maciço geológico, indicando não existir conseqüências indesejáveis no entorno da pedreira, visto a inexistência de habitantes, edificações e pastagens num raio da ordem de 1,0 km”.

Dentre as medidas anunciadas nos pareceres do Daia como tendo origem no EIA ou em suas complementações, foram encontradas novas propostas ou detalhes adicionais não presentes nos documentos do proponente. Os seguintes exemplos ilustram esta condição:

1. “Observância da norma ABNT que especifica para a sobrepressão do ar, em locais além da operação da mina, o limite máximo correspondente a um nível de pressão acústica de pico de $130 \mathrm{~dB}$ e para velocidade de partícula o máximo de $15 \mathrm{~mm} / \mathrm{s}$ ". Vale lembrar que a norma ABNT provavelmente referida (ABNT,1989) estabelece 134 dB para o nível máximo de pressão acústica.

2. “Observação do mapeamento da cobertura vegetal e das determinações do DEPRN, direcionando os desmatamentos, no sentido sudoeste, sobre uma área já bastante degradada, de modo a manter a integridade das manchas de mata ao redor da pedreira, que se encontram em melhor estado de preservação”. Não são anexados ao parecer os mapas de cobertura vegetal referidos no texto. 
3. "Recomposição vegetal com gramíneas nos taludes do pátio da unidade de britagem e plantio de vegetação de porte arbóreo ao longo das vias de acesso".

O segundo grupo de medidas enumeradas no parecer do Daia, intitulado exigências técnicas, também merece comentários. Juntamente com medidas mitigadoras, compensatórias, de recuperação de área ou de monitoramento, o Daia inclui sob esta designação a manifestação de preocupações ou a reafirmação de procedimentos vigentes e distribuição de competências. São exemplos ilustrativos desta condição, os seguintes:

1. "Nas bacias de decantação, deverão ser despendidos cuidados especiais no controle do assoreamento basal e infiltrações eventuais no fundo ("underflow"), capazes de potencialmente induzir anomalias localizadas na superfície do lençol freático".

2. "Que exigências aqui apresentadas sejam condicionantes para as etapas seguintes do licenciamento, principalmente, quando da emissão da licença de instalação pela Cetesb, a qual deverá observar seu cumprimento e fiscalizá-los".

3. “O empreendedor deverá executar as medidas mitigadoras apresentadas no EIA/Rima e complementações".

Ainda com relação às exigências técnicas, a mais comum é a obrigatoriedade de apresentação de relatórios de monitoramento periódicos, sem definir, no entanto, a quem compete analisá-los. Algumas exigências são formuladas para o empreendedor, como a solicitação de estudos técnicos adicionais, enquanto outras são dirigidas à Cetesb, como a transferência de atribuição de avaliá-los. Em alguns casos, o Daia propõe novas medidas mitigadoras ou novas formulações para medidas propostas pelo empreendedor. A seguir, são apresentados e comentados alguns exemplos de exigências técnicas presentes nos pareceres examinados:

1. "Aprovação pela Cetesb do sistema de tratamento de esgotos, de óleos e graxas, bem como do projeto de drenagem da mina e retenção de sedimentos".

2. “A emissão da LF pela Cetesb deverá estar vinculada à apresentação do contrato proposto pelo estudo para monitoramento da poeira em suspensão àquela empresa”.

3. “Implementação efetiva de medidas para a prevenção de infiltração no fundo das barragens e nas bacias de decantação (recobrimento do fundo com geomembranas, drenagem subterrânea, impermeabilização etc.)". Trata-se, neste caso, da proposição, de maneira vaga e imprecisa, de medida mitigadora no mínimo discutível que, além de onerosa, pode interferir na eficiência do processo de disposição de rejeitos. 
4. Em um dos casos, tratando do tema impermeabilização de lagoas de decantação, o Daia inclui na forma de exigências o seguinte texto: "acompanhamento da eficiência do sistema de impermeabilização: caso sejam verificadas infiltrações, recomendamos o revestimento das lagoas com camada de $20 \mathrm{~cm}$ constituída pela mistura bentonita-cimento, na proporção 2:1".

Eliminando-se as repetições e impropriedades, o número total de medidas ambientais apresentadas nos pareceres do Daia examinados variou de 13 a 32, incluindo tanto aquelas supostamente propostas pelo empreendedor como as denominadas exigências técnicas, formuladas pelo Daia. Quanto à exeqüibilidade de fiscalização, as 128 medidas distribuíram-se em: 30\% (39 medidas) fiscalizáveis, 18\% (23 medidas) não fiscalizáveis e 52\% (66 medidas) fiscalizáveis, porém requerendo interpretação e avaliações subjetivas por parte dos agentes de fiscalização. A Tabela 5.5 resume o cômputo geral das medidas propostas no parecer do Daia e sua classificação quanto à formulação.

Tabela 5.5: Medidas propostas no parecer do Daia e sua classificação quanto à formulação

\begin{tabular}{l|c|c|c|c|c|c|c}
\hline \multicolumn{1}{c|}{ CLASSIFICAÇÃO } & Caso 1 & Caso 2 & Caso 3 & Caso 4 & Caso 5 & Caso 6 & Total \\
\hline Fiscalizável & 7 & 4 & 12 & 5 & 9 & 2 & 39 \\
\hline Não-fiscalizável & 7 & 4 & 6 & 2 & 2 & 2 & 23 \\
\hline Parcialmente fiscalizável & 11 & 10 & 14 & 7 & 15 & 9 & 66 \\
\hline \multicolumn{1}{c|}{ TOTAL } & 25 & 18 & 32 & 14 & 26 & 13 & 128 \\
\hline
\end{tabular}

\subsubsection{Medidas expressas na deliberação do Consema}

Em todos os casos examinados, o Consema esclarece em sua deliberação de aprovação do EIA/Rima que esta decisão baseou-se no parecer do Daia. Em três dos casos estudados é explicitada a obrigatoriedade de o empreendedor cumprir as medidas mitigadoras propostas no EIA/Rima, mas em um caso o texto limita esta obrigação às medidas constantes do parecer do Daia e em dois casos não há referência a esta obrigação. Em nenhum dos casos há qualquer menção às formulações apresentadas pelo proponente em documentos complementares. Além das medidas mitigadoras propostas no EIA/Rima, a deliberação do Consema estabelece exigências adicionais que em alguns casos têm origem no parecer do Daia e em outros provém de sugestões formuladas na reunião plenária de aprovação do estudo. Algumas destas medidas são formuladas como condição à obtenção das licenças de instalação ou de funcionamento.

Deste modo, considerando-se que a deliberação do Consema é um documento de decisão sobre a viabilidade ambiental do empreendimento proposto, identificam-se dois 
grupos de condicionantes para sua aprovação. O primeiro grupo é o das medidas propostas no EIA, não transcritas neste documento final. O segundo grupo é o das exigências, transcritas do parecer do Daia ou formuladas na reunião do Consema.

Com relação às medidas propostas no EIA e assumindo a hipótese de que os documentos complementares constituem parte integrante do EIA, o conhecimento destes condicionantes requereria o exame dos vários documentos técnicos apresentados pelo proponente, assim como o parecer do Daia. Conforme exposto nos itens precedentes, esta é uma tarefa difícil, tanto no que concerne à localização das informações como a sua interpretação.

Quanto às exigências expressas no texto da deliberação do Consema, seu número variou entre 2 e 10 propostas, conforme o caso estudado. A maior parte destas medidas foi transcrita do parecer do Daia literalmente ou com ligeiras alterações. Em alguns casos houve a transformação de recomendações do Daia em exigências. Dentre as exigências consideradas novas, foram encontradas as seguintes situações:

1. Exigência que introduz alterações profundas no plano de recuperação da área minerada proposto, além de ser de difícil fiscalização, uma vez que determina as espécies de peixes a ser introduzidas no povoamento dos lagos remanescentes na área recuperada.

2. Exigências que apenas reafirmam a obrigatoriedade de implementação do Prad ou a necessidade de implementá-lo simultaneamente ao desenvolvimento das atividades de lavra. Além de se constituírem em diretrizes gerais, são repetitivas em relação aos documentos anteriores, em particular ao parecer do Daia.

3. Exigências cujo conteúdo corresponde a um novo pedido de complementação, já que solicitavam detalhamento de estudos ou novos estudos e modificações em parâmetros de projeto. Como esta complementação deveria ser entregue ao Daia, este emitiu um novo parecer contendo sete exigências adicionais.

4. Solicitação de informação que pode ser considerada básica para a avaliação do projeto (classificação do córrego adjacente à área do projeto).

5. Exigência de submissão do projeto ao órgão competente para aprovação e controle das medidas de proteção à saúde do trabalhador.

\subsection{A etapa de acompanhamento}

No âmbito do sistema ambiental do Estado de São Paulo, após a aprovação do EIA, que corresponde à obtenção da licença prévia, o empreendimento depende ainda da licença de instalação (LI) e de funcionamento (LF) outorgadas pela Cetesb; de 
autorizações de desmatamento ou de ocupação de área de preservação permanente emitidas pelo DEPRN; e de licença do Dusm, no que toca à Lei de Proteção aos Mananciais da RMSP. Deve, em princípio, ser fiscalizado por estes três órgãos, além do Daia, cada um cuidando dos aspectos de sua competência.

O órgão mais atuante em todos os casos estudados foi a Cetesb, seguido pelo DEPRN. Com relação ao Dusm, apesar de um dos casos selecionados para estudo estar inserido nos limites de jurisdição da Lei de Proteção aos Mananciais da Região Metropolitana de São Paulo, não havia processo referente ao empreendimento naquele departamento, razão pela qual seus arquivos não foram examinados.

O Daia, nesta etapa posterior à aprovação do EIA, aparentemente limitou-se a registrar o recebimento dos relatórios semestrais de monitoramento, encaminhando alguns para a Cetesb, outros para o DEPRN e arquivando os demais. Não existem registros de aprovação ou mesmo de análise destes relatórios.

\subsubsection{A atuação da Cetesb}

A atuação da Cetesb no controle ambiental dos empreendimentos estudados iniciou-se com a abertura do processo de licenciamento, que em três casos precedeu a apresentação do EIA/Rima à SMA. Em um dos casos, durante a tramitação do estudo, a Cetesb realizou vistorias e constatou que o empreendimento não havia sido implantado, em outro, porém, arquivou o processo e não fez vistorias durante os cerca de 16 meses decorridos entre o pedido de licença e a aprovação do EIA. Ao final deste período, constatou que a "indústria encontrava-se completamente instalada", o que pode evidenciar que a empresa iniciou suas atividades antes da aprovação do EIA e concessão da LI.

No terceiro caso em que a atuação da Cetesb precedeu a apresentação do EIA, a abertura do processo de licenciamento ocorreu cerca de 17 meses antes da protocolização do estudo. Nesse período e durante a tramitação do EIA, a Cetesb intermediou os contatos entre o proponente do projeto e a SMA e inspecionou a área. Apesar de ter constatado que a instalação fora iniciada sem a devida licença, não aplicou penalidade. 
Nos demais casos, a abertura do processo de licenciamento e, portanto, a atuação da Cetesb, iniciou-se formalmente após a aprovação do EIA/Rima. O tempo decorrido entre estes dois eventos variou de dois a oito meses, conforme o caso.

Conforme exposto nos itens precedentes, depende de consulta aos vários documentos que compõem o processo de AIA - o EIA, o Rima, as complementações, o parecer do Daia e a deliberação do Consema - o conhecimento do projeto aprovado, bem como das medidas ambientais definidas no processo de AIA, essencial para sua fiscalização. Apesar disso, o exame dos processos Cetesb revelou que os únicos documentos incorporados ao processo de licenciamento em todos os casos foram o parecer do Daia e a deliberação do Consema, embora nem sempre completos. Em um dos casos estudados, três das exigências enumeradas no parecer do Daia reportavam-se a mapas ou plantas que não foram apensados ao processo, tornando a fiscalização do seu cumprimento no mínimo mais difícil. Os outros documentos encontravam-se arquivados na regional em apenas três dos casos estudados.

Quanto aos demais, em um deles constava do processo Cetesb o registro de recebimento do EIA e do Rima, mas os técnicos encarregados da fiscalização do empreendimento não conheciam o estudo e não sabiam onde havia sido arquivado. Em dois outros não havia sequer registro de recebimento. Os técnicos encarregados da fiscalização do empreendimento havia vários anos desconheciam o EIA, o Rima e as complementações e não souberam informar se existiam cópias destes documentos no escritório regional. Todo o seu conhecimento a respeito do processo de AIA restringiase ao conteúdo do parecer do Daia e da deliberação do Consema.

Nos processos de licenciamento simples, quando a licença de instalação não é precedida de aprovação de EIA, a Cetesb analisa o projeto com base nas informações constantes do memorial de caracterização do empreendimento e em inspeções que realiza, além de eventuais consultas a setores especializados dentro da própria companhia. O resultado desta análise é a identificação dos aspectos do projeto potencialmente causadores de poluição das águas, do ar ou do solo, abrangidos pela Lei Estadual nº 997/76 e Decreto Estadual nº 8468/76 que a regulamenta, e a formulação de exigências que são expressas na LI. O cumprimento destas exigências é acompanhado e constitui requisito obrigatório para a obtenção da licença de funcionamento que, por sua 
vez, contém outras exigências que norteiam a fiscalização ao longo da vida útil do empreendimento.

Nos casos estudados, a Cetesb procurou incorporar às exigências da LI os condicionantes originados no processo de AIA, baseando-se nos textos da deliberação do Consema e do parecer do Daia. O número de exigências constantes da LI variou de três a nove, parte delas originadas do processo de AIA, como mostra a Tabela 5.6.

Tabela 5.6: Exigências formuladas na licença de instalação (LI)

\begin{tabular}{l|c|c|c|c|c|c}
\hline \multicolumn{1}{c|}{ ORIGEM } & Caso 1 & Caso 2 & Caso 3 & Caso 4 & Caso 5 & Caso 6 \\
\hline Processo de AIA & 4 & 2 & 5 & 2 & 1 & 2 \\
\hline Legislação de controle da poluição & 2 & 2 & 3 & 7 & 2 & 3 \\
\hline TOTAL & 6 & 4 & 8 & 9 & 3 & 5 \\
\hline
\end{tabular}

Como se observa, apenas uma pequena parte das medidas ambientais formuladas no parecer do Daia e deliberação do Consema foi transformada em exigência na LI. As demais foram contempladas em formulações abrangentes como "a empresa deverá cumprir as demais exigências constantes na deliberação do Consema" ou "a empresa deverá cumprir as demais exigências preconizadas no parecer técnico do Daia, que acompanha a deliberação do Consema", ou ainda, "a entidade deverá atender integralmente às exigências contidas no parecer do Daia”. Em nenhum dos casos estudados foi formulada exigência de cumprimento das medidas propostas no EIA, Rima e complementações.

Quanto às medidas formuladas no parecer do Daia ou na deliberação do Consema e posteriormente transformadas em exigências na LI, algumas foram simplesmente transcritas, enquanto outras foram reformuladas pela Cetesb. Esta reformulação buscava, em alguns casos, detalhar a medida, tornando sua fiscalização menos dependente de interpretações e avaliações subjetivas, e em outros, suprimir detalhes, ampliando as possibilidades de emprego de soluções alternativas para a atenuação do impacto objetivado. São exemplos destas condições:

1. "Implantar 03 (três) poços de monitoramento do lençol freático, cujos perfis geológicos e construtivos deverão ser apresentados à Cetesb, na construção dos mesmos, os quais deverão ser locados conforme croquis constante da página .......do Processo $\mathrm{n}^{\mathrm{o}}$...... e deverão estar implantados e em condições de serem vistoriados por ocasião da Licença de Funcionamento." Na deliberação do Consema, esta medida referia-se apenas a "poços circunvizinhos", sem especificação do número, método construtivo ou localização. 
2. “Instalar piezômetro geotécnico multinível na crista das barragens, destinado a monitorar a sua estabilidade geomecânica (modificação das condições de fluxo natural, formação de 'piping', carreamento de finos etc.). A profundidade do piezômetro deverá se estender até o seccionamento das camadas de sedimentos e de regolito, com o posicionamento adequado dos sensores. Neste piezômetro deverão ser efetuadas as amostragens de água para análises periódicas.” A deliberação do Consema apenas recomendava que "os diques e barragens deverão ser criteriosa e periodicamente monitorados, no que se refere à ocorrência de 'piping' eventual, infiltrações, rachaduras de acomodação dos maciços etc."

3. “Adotar medidas de umectação nos pátios de movimentação de veículos automotores, bem como nas áreas descobertas ou de armazenagem ao ar livre de produtos acabados, de modo a impedir o arraste, pela ação dos ventos, dos materiais pulverulentos" e "instalar sistema de umectação permanente, com base na melhor tecnologia prática disponível para controle de material particulado, proveniente das operações de transporte em correias transportadoras, moagem de pedras em britadores e peneiramento". No parecer do Daia, o sistema de umectação era especificado, carros-pipa nas "estradas de serviço" e pulverização por sistema de bicos aspersores nas "etapas de britagem e peneiramento de rochas".

4. “Com respeito à segurança das edificações vizinhas, deverão ser adotados os valores estabelecidos pela NBR 9653, da ABNT”. O parecer do Daia não mencionava o número da norma e reproduzia parcialmente os valores de referência: "nível de pressão acústica de pico de 130 dB e para a velocidade de partícula o máximo de $15 \mathrm{~mm} / \mathrm{s}$ ". Conforme comentado anteriormente, a norma ABNT estabelece o nível máximo de $134 \mathrm{~dB}$ para a pressão acústica.

5. “Os efluentes líquidos domésticos deverão ser tratados e dispostos segundo a NBR 7229 da ABNT". Pelo parecer do Daia os efluentes domésticos seriam "dispostos em um sistema de fossa séptica/poço absorvente".

6. "Instalar sistema de controle de poluição atmosférica, baseado na melhor tecnologia prática disponível para as operações de britagem, rebritagem, classificação, transporte por correias e pontos de transferência" e "tomar medidas adequadas a fim de evitar a emissão de poluentes na atmosfera que possam causar incômodos à vizinhança, provenientes das operações de desmonte de rochas por explosivos, carregamentos e descarregamentos de caminhões". Pelo parecer do Daia, a emissão de poeira "na operação de carregamento e transporte de material será minimizada através de aspersão de água no percurso e durante o beneficiamento, o desprendimento de poeiras será reduzido com a aspersão de água através de sistema apropriado de filtros de ar ligados ao britador”.

Após a concessão da LI, a atuação da Cetesb concentrou-se, de modo geral, na fiscalização do cumprimento das exigências formuladas na licença, o que incluía medidas de controle de poluição e medidas originadas do processo de AIA. Além destas exigências, a Cetesb acompanhou a instalação do empreendimento, focalizando especialmente os aspectos abrangidos pela Lei Estadual n ${ }^{0}$ 997/76 e seu regulamento. A 
eventual ocorrência de reclamações de vizinhos também contribui para desviar as atenções da fiscalização, concentrando-a nos aspectos objeto das queixas.

Ao tratar dos aspectos de prevenção e controle da poluição, abrangidos por leis e regulamentos, no entanto, algumas das medidas propostas no processo de AIA eram retomadas, nem sempre com o mesmo conteúdo. Os processos administrativos analisados registram em várias ocasiões mudanças de orientação dadas pela Cetesb em relação ao cumprimento de medidas mitigadoras e de monitoramento definidas no processo de AIA. Em nenhum dos casos há registro de que as alterações tenham sido comunicadas ao Daia ou ao Consema. São exemplos de alterações:

1. Uma das exigências propostas pelo Daia e referendadas pelo Consema era a de "aprovação pela Cetesb do sistema de tratamento de esgotos, de óleos e graxas, bem como do projeto de drenagem da mina e retenção de sedimentos". Logo após a primeira inspeção, a Cetesb dispensou a empresa do cumprimento da parte da exigência relativa a óleos e graxas, substituindo-a por um controle do destino destes materiais.

2. A exigência de contratação de serviços da Cetesb para o monitoramento das poeiras em suspensão é substituída pela aquisição pela empresa de um equipamento (High Volume Sampler - Hivol) e apresentação de plano de monitoramento. De acordo com o técnico da Cetesb encarregado do acompanhamento da empresa, este monitoramento foi feito durante os dois primeiros anos de funcionamento, quando a Cetesb passou a fazer inspeções de rotina.

3. A instalação de uma estação meteorológica para evitar detonações em condições adversas foi substituída por aquisição dos dados de estação existente próximo ao local.

4. A "execução de análises mensais, nos dois corpos d'água que drenam a área", com observação de seis parâmetros de qualidade, é considerada desnecessária e exagerada pelos técnicos da Cetesb e nunca foi exigida da empresa.

5. Especificações de materiais e procedimentos para impermeabilização do fundo de uma lagoa de decantação são substituídas pela exigência de um sistema de captação e tratamento de finos adequado para impedir a poluição das coleções hídricas, com destaque para os padrões de lançamento de efluentes em coleções hídricas.

6. A descrição dos materiais e métodos empregados no desmonte por explosivos é substituída por especificação dos limites máximos de pressão sonora e velocidade de vibração admitidos.

7. O sistema de impermeabilização de fundo de algumas lagoas de decantação de efluentes do beneficiamento, apesar de ter sido uma das grandes preocupações durante o processo de AIA, não é cobrado, mas a Cetesb exige a instalação de piezômetros para monitoramento da contaminação do freático, solicita estudos sobre condições de estabilidade dos diques de contenção, além de ensaios de caracterização dos lodos sedimentados. 
8. Apesar de o empreendimento ter sido instalado e funcionar há vários anos, as exigências relativas ao “acompanhamento da qualidade das águas através de análises periódicas de suas características físico-químicas (cor, turbidez, óleos e graxas, pH e resíduos sólidos totais) a intervalos regulares de seis meses" e "seções batimétricas e análises granulométricas a cada ano" somente passaram a ser cobradas pela Cetesb após a emissão da LF.

Medidas consideradas fora da área de competência do órgão ou tidas como desnecessárias por seus técnicos simplesmente não foram acompanhadas ou exigidas. É o caso das questões que envolviam vegetação, que somente foram tratadas quando diretamente relacionadas ao controle de processos erosivos que pudessem favorecer o carreamento de sólidos em suspensão para corpos d'água adjacentes à área. Em um dos casos estudados, nos primeiros anos após a concessão da LI, algumas medidas enumeradas no parecer do Daia chegaram a ser acompanhadas, mas a interpretação dos técnicos era confusa e equivocada. Transformava, por exemplo, a determinação do Consema de não permitir a extração de areia nas proximidades das lagoas marginais ao rio, de longe a questão mais debatida durante aquele processo de AIA, em proibição de lavrar sobre as tais lagoas, que de todo modo nunca foi fiscalizada por falta de equipamento (barco).

Em que pesem as diferenças observadas nas várias regionais visitadas, a Cetesb esteve presente e atuante na fiscalização das empresas, mas pautou-se por seus próprios instrumentos e critérios, acompanhando apenas burocraticamente o atendimento, não ao conjunto dos condicionantes do processo de AIA, mas apenas às exigências contidas na deliberação do Consema ou às medidas enumeradas no parecer do Daia. Com efeito, a atuação da Cetesb com relação aos condicionantes do processo de AIA, salvo poucas exceções, limitou-se a registrar nos autos a necessidade de verificar seu cumprimento, ou reproduzir declarações de representantes do empreendedor garantindo que as medidas estavam sendo "cumpridas paulatinamente".

Apesar de presente e atuante, na maior parte dos casos a Cetesb teve uma atitude marcada pela tolerância, ou seja, permitiu que empreendimentos funcionassem sem licença por longos períodos - até nove anos em um dos casos -; ou, após o esgotamento dos prazos concedidos em licenças de funcionamento a título precário e, mesmo tendo lavrado muitos autos de infração, raramente os converteu em multa.

Os técnicos encarregados da fiscalização dos empreendimentos estudados foram unânimes em afirmar que faltam instrumentos jurídicos e administrativos para exigir o 
cumprimento das medidas mitigadoras preconizadas no EIA/Rima quando estas não se enquadram na legislação de controle da poluição, ou seja, não basta a exigência, é preciso "estar na lei". Além disso, alguns técnicos mostraram-se insatisfeitos com a articulação entre a Cetesb, DEPRN e Daia para a fiscalização dos empreendimentos.

Um dos técnicos consultados considera que o EIA é útil para a Cetesb na identificação dos aspectos que devem ser acompanhados, porém o acompanhamento é dinâmico e específico, dependendo do desempenho da empresa e de eventuais reclamações, entre outros fatores. De acordo com este técnico, a Cetesb faz o mesmo acompanhamento de empresas que não foram submetidas ao processo de AIA, controlando a poluição do ar, da água, ruídos e vibrações, apoiada na legislação vigente, em particular nos dispositivos da Lei $n^{0}$ 997/76 e do Decreto $n^{0}$ 8468/76.

\subsubsection{A atuação do DEPRN}

Apesar de muitas das medidas mitigadoras e de monitoramento estabelecidas nos vários processos de AIA estudados tratarem de assuntos da esfera de competência do DEPRN, somente em um dos casos foi localizado nesse órgão o processo relativo ao empreendimento. Nos demais, a atuação do DEPRN restringiu-se à etapa inicial do

processo, quando elaborou parecer técnico definindo condicionantes para o empreendimento, dentro de sua área de competência. Os pareceres técnicos foram localizados dentro do processo administrativo do Daia, porém o processo administrativo correspondente não foi encontrado no DEPRN.

Em dois dos casos estudados, mesmo não tendo sido localizado o processo no DEPRN, foram encontradas evidências de atividades de fiscalização, embora não sistemática. Em uma das minas visitadas, os funcionários da empresa relataram que um técnico do Órgão havia inspecionado a área e dado orientação verbal sobre o cumprimento das medidas mitigadoras de competência do DEPRN relacionadas no parecer do Daia. Em outro caso, foi apensada ao processo Cetesb cópia de um laudo de vistoria referido como inserido em um "Programa de Fiscalização de Empreendimentos Minerários” destinado à "verificação da implementação do EIA/Rima”. No escritório do DEPRN, no entanto, não foram encontrados registros desta iniciativa.

O laudo afirmava que "o empreendimento implementou e vem implementando satisfatoriamente as medidas propostas para a mitigação dos impactos ambientais e 
recuperação da área degradada pela mineração", destacando algumas das medidas: cortina vegetal; remoção e estocagem adequada do solo vegetal na operação de decapeamento e seu emprego na recuperação da área minerada. O laudo tratava também de assuntos alheios à esfera de competência do DEPRN, como poluição de águas, coleta de óleos e graxas provenientes da manutenção dos equipamentos e construção de fossa séptica de acordo com norma ABNT.

Surpreendentemente, o laudo concluía com elogios ao empreendimento: "é um dos raros empreendimentos minerários que, até agora, cumpriu com as propostas apresentadas no EIA/Rima, inclusive aquelas sociais relativas à geração de empregos. $\mathrm{O}$ porto, tal como vem sendo operado, demonstra a viabilidade da operação, minimização de impactos e recuperação simultânea da área degradada e desmente afirmações de alguns mineradores de ser impossível tal procedimento. Recomenda-se usar o porto como exemplo para as minerações que utilizam a mesma forma de explotação mineral e características semelhantes".

No único caso em que o processo administrativo relativo ao empreendimento foi localizado no DEPRN, constatou-se que sua existência deveu-se a uma modificação no projeto original aprovado no processo de AIA. Embora o projeto original, constante do processo de avaliação de impacto ambiental, contemplasse a instalação de bacia de sedimentação com $400 \mathrm{~m}^{2}$ fora de área de preservação permanente, o empreendedor constatou posteriormente que somente dispunha de espaço para a instalação deste equipamento em área de várzea, junto à lagoa natural formada após cheias do rio. Um projeto alternativo - caixas de decantação ocupando $120 \mathrm{~m}^{2}$ - foi encaminhado ao DEPRN para autorização de construção em área de preservação permanente.

Ao pedido de autorização e memorial descritivo do projeto foram anexadas cópias do parecer técnico do Daia e da deliberação do Consema, informando o DEPRN que a solicitação destinava-se a cumprir exigência decorrente do processo de avaliação de impacto ambiental. Em laudo de vistoria, no entanto, o responsável destacava apenas que a solicitação visava a cumprir exigência da Cetesb e que o local situava-se "dentro de área de preservação permanente, não em relação ao rio, mas devido à presença de lagoas naturais formadas após cheias do rio, caracterizando áreas de várzea", mas "a caixa de decantação não causará degradação ambiental". 
O processo foi remetido a instância superior com recomendação de consulta ao Ibama, retornando com orientação expressa para "atentar para as medidas mitigadoras expostas na deliberação Consema". Estabeleceu-se uma polêmica sobre procedimentos internos que retardou o atendimento à solicitação, porém, ao fim de dez meses foi emitido um atestado de regularidade florestal com a exigência de recuperação da área de preservação permanente com plantio de espécies nativas e frutíferas adequadas à fauna silvestre e ictiofauna. A formulação imprecisa da exigência dificultaria a fiscalização de seu cumprimento, o que foi destacado em laudo de vistoria posterior, elaborado por outro técnico do órgão.

Às solicitações de manifestação formuladas pela Cetesb sobre os aspectos do plano de recuperação, medidas mitigadoras e plano de monitoramento estabelecidos no processo de avaliação de impacto ambiental, o DEPRN responde laconicamente informando que "não houve plantio de essências nativas ou enriquecimento da vegetação natural no local". Vale lembrar que, das 18 medidas enumeradas no parecer do Daia, oito podiam ser consideradas de competência do DEPRN, por tratarem da cobertura vegetal, áreas de preservação permanente, tratamento do solo e plantio de espécies nativas.

No entender do técnico do DEPRN, a fiscalização do órgão não tem de ser periódica ou sistemática, e sim quando solicitada pelo Ministério Público ou pela Cetesb. Mesmo assim, o técnico entende que o DEPRN tem suas próprias prioridades e não pode atuar a reboque da Cetesb, do Daia e do Consema. Não existe, a partir da aprovação do EIA, um procedimento de fiscalização sistemática das medidas mitigadoras e outras, mesmo quando na esfera de competência do DEPRN.

\subsubsection{A atuação do Daia}

O Daia, nesta etapa posterior à aprovação do EIA, praticamente saiu de cena. Em dois dos casos estudados, não foram encontrados registros de sua atuação ou mesmo de contatos posteriores com a Cetesb ou DEPRN. Mesmo os relatórios de acompanhamento exigidos em parecer do Daia, aparentemente não foram entregues e tampouco cobrados.

Em dois outros casos, o Daia, após a emissão do parecer que fundamentou a aprovação do EIA, limitou-se a receber e arquivar ou encaminhar para a Cetesb os 
relatórios de monitoramento entregues em cumprimento de exigências formuladas no referido parecer e na deliberação do Consema. Em um caso em que o relatório de monitoramento foi encaminhado à Cetesb, o Daia solicitava manifestação daquele órgão quanto aos aspectos de sua competência, esclarecendo que questões relativas à "estabilidade de diques e barragens" seriam analisadas pelo Daia e "revegetação" pelo DEPRN. Nenhum documento de avaliação do relatório foi encontrado. Em outro caso, de seis relatórios recebidos pelo Daia, apenas o primeiro foi analisado e recebeu parecer, os demais foram remetidos à Cetesb, que analisou os primeiros e limitou-se a arquivar os seguintes.

Em um dos casos examinados, está registrado na ficha de protocolo do Daia o recebimento de uma correspondência propondo alteração do teor de uma das medidas de monitoramento, e de duas vias do primeiro relatório semestral de monitoramento. Tanto a correspondência como o relatório encontram-se arquivados junto com os demais documentos e têm carimbos de recebimento, porém não foram encontradas evidências de análise, resposta ou outra providência.

No único caso em que o Daia realmente atuou, a ficha de protocolo apresentava três registros posteriores à aprovação do EIA, sendo que o primeiro deles ocorreu mais de sete anos após este evento. O Daia foi acionado pela Cetesb, que constatou que o empreendedor estava em débito com exigências formuladas na deliberação do Consema. Por orientação do Daia, a Cetesb exigiu do empreendedor um plano de recuperação da área degradada que faltava no processo original e, ao recebê-lo, encaminhou-o ao Daia para análise. O Daia, então, analisou o histórico do empreendimento, fez vistoria e analisou o Prad, constatando várias irregularidades. O parecer emitido na ocasião resume a situação e aponta caminhos para a regularização do empreendimento.

\subsubsection{A atuação do Dusm}

Apenas um dos casos selecionados para estudo estava inserido nos limites de jurisdição da Lei de Proteção aos Mananciais da Região Metropolitana de São Paulo. A licença do Dusm, no entanto, não foi solicitada e o único registro do empreendimento existente naquele Departamento correspondia à solicitação de orientação sobre as restrições à ocupação da área, cujo parecer, denominado Análise de Orientação, havia sido incluído no relatório complementar ao EIA e encaminhado ao Daia. De acordo com o parecer do Daia, a verificação da compatibilidade do projeto com as restrições 
constantes da análise de orientação somente seria verificada pelo órgão competente após a aprovação do EIA e mediante solicitação que, ao que tudo indica, nunca foi feita.

\subsection{0 empreendimento real}

Com o propósito de examinar as características do empreendimento instalado e as medidas ambientais implementadas, confrontado-as com os condicionantes definidos no processo de AIA, foram feitas visitas às minas. Foram apenas cinco visitas, uma vez que um dos mineradores não autorizou a pesquisa. As visitas, com duração de cerca de duas a três horas, foram acompanhadas por representantes do minerador, o que possibilitou que as observações diretas fossem complementadas por informações e esclarecimentos fornecidos, ora por um dos sócios proprietários do empreendimento, ora por engenheiro, geólogo ou encarregado de produção da empresa.

Em dois dos empreendimentos, a visita foi guiada por pessoa que acompanhava o processo desde o início e conhecia bem os aspectos ambientais do projeto, bem como detalhes do processo de AIA e do processo de licenciamento. Já em dois outros, os profissionais que acompanharam a visita trabalhavam como consultores da empresa há tempo relativamente curto e, embora a representassem perante os órgãos ambientais, ignoravam os documentos iniciais do processo de AIA (EIA, Rima, complementações) e conheciam apenas precariamente o parecer do Daia e a deliberação do Consema, assim como os procedimentos de avaliação de impacto e licenciamento. No caso restante, o profissional, além de trabalhar há pouco tempo na empresa, não tratava diretamente das questões ambientais, que eram conduzidas por empresa de consultoria especializada.

Além das dificuldades associadas ao tempo disponível para a visita e ao nível de conhecimento que a pessoa destacada para acompanhá-la detinha 32 , em duas das minas visitadas, o sistema de britagem estava parado para manutenção, o que restringiu as observações diretas às atividades de desmonte primário e carregamento do material já britado anteriormente. Em outra mina, a visita foi rápida e somente foram mostrados aspectos gerais das áreas de lavra e atividades ao ar livre; as instalações de beneficiamento não foram visitadas.

\footnotetext{
${ }^{32}$ É importante esclarecer que esta etapa da pesquisa dependia basicamente da colaboração voluntária dos mineradores, que, portanto, determinaram datas, pessoas, tempo disponível e abrangência da visita.
} 
Apesar desses problemas, foi possível encontrar numerosas evidências de nãocumprimento ou cumprimento insatisfatório das medidas definidas no processo de AIA, bem como de falhas nas atividades de fiscalização. A seguir, são apresentados alguns exemplos ilustrativos:

1. Embora preocupações com os métodos construtivos das barragens de rejeito, em particular os aspectos de segurança e impermeabilização de fundo, tenham marcado o processo de AIA, dando origem a exigências de estudos complementares e várias medidas de mitigação e monitoramento, tanto no parecer do Daia como na deliberação do Consema, a construção destas barragens não obedecia a nenhum esquema de projeto e o monitoramento de sua estabilidade limitava-se a inspeções visuais para observação de infiltrações. Por exigência da Cetesb, três piezômetros chegaram a ser instalados na primeira barragem, mas foram soterrados quando de sua desativação. Nas barragens construídas posteriormente, não foram instalados novos piezômetros, assim como nenhum tipo de impermeabilização de fundo foi executado antes do enchimento, como havia sido definido no processo de AIA.

2. Conforme definido no processo de AIA, haviam sido perfurados poços para monitoramento do lençol freático e eram feitas análises periódicas da qualidade física e química das águas do corpo d'água receptor, a montante e a jusante. Estas medidas, entretanto, eram utilizadas apenas pelos consultores para elaboração dos relatórios de monitoramento entregues ao Daia. O proprietário e demais envolvidos no gerenciamento da mina não tomavam conhecimento dessas informações e, conseqüentemente, não as utilizavam na condução do empreendimento.

3. Apesar de estabelecido no parecer do Daia, não havia sinais de implantação de cobertura vegetal nas estruturas de contenção, diques e barragens, e a cortina vegetal, que deveria atuar como barreira visual em todo o perímetro da mina, em alguns trechos era constituída de uma única fileira de pinheiros ou bananeiras, claramente insuficiente para o objetivo almejado (Foto 1).

4. O sistema de tratamento das águas provenientes de pilhas de areia, aprovado no processo de AIA, consistia em bacia de sedimentação sem revestimento, com $400 \mathrm{~m}^{2}$, localizada fora da área de preservação permanente. O sistema construído consistia em quatro caixas de concreto, com área total de $120 \mathrm{~m}^{2}$, e situava-se em área de preservação permanente (Foto 2).

5. Embora presente entre as medidas ambientais enumeradas no parecer do Daia, reafirmada com ênfase como exigência tanto neste documento como na deliberação do Consema, revelando a importância atribuída à questão na avaliação dos impactos, a proibição de minerar nas imediações das lagoas marginais e das margens do rio não somente não é obedecida, como é completamente desconhecida dos responsáveis pela produção da mina.

6. Contrariamente a várias medidas de proteção à área de inundação definidas no processo de AIA, vários galões de combustível encontravam-se próximo à linha d'água, a manutenção das dragas era feita dentro d'água, favorecendo a contaminação das águas do rio por óleos e graxas, o material 
sedimentado nas caixas de decantação era depositado para secagem em área de inundação, próximo à linha d'água (Fotos 3, 4, 5 e 6).

7. Apesar de o empreendimento encontrar-se instalado há vários anos, a barreira vegetal plantada na divisa da propriedade com a estrada não passa de uma fileira única de árvores jovens, recémplantadas, que não cumpre nenhum dos objetivos a que se prestava, ou seja, atenuar os impactos visuais, o ruído e a poeira. Também são em número insuficiente e de introdução recente as essências nativas plantadas para enriquecimento da vegetação ciliar (Fotos 7 e 8),

8. Previstos no processo de AIA e constatados em várias inspeções da Cetesb, os sistemas de aspersão de água nas operações de britagem e nas estradas de serviço não estavam operando no dia da visita. O primeiro encontrava-se em manutenção e não foi possível observar seu funcionamento, exceto por meio de evidências indiretas, como o acúmulo de material fino úmido depositado sob o sistema de correias transportadoras. O único caminhão pipa existente na mina que, segundo os funcionários da empresa, funciona ininterruptamente, umectando as vias externas (desde o entroncamento com a estrada), as vias internas e o pátio de carregamento para expedição, encontrava-se em manutenção no início da visita, mas retomou sua atividade em tempo de ser observado ( Fotos 9 e 10).

9. As várias exigências relacionadas às operações de detonação não estavam sendo cumpridas da maneira como foram formuladas em razão dos avanços tecnológicos havidos desde a avaliação do empreendimento. Ademais, as especificações constantes das exigências eram muito detalhadas, conforme já comentado. Assim, empregava-se no empreendimento, por ocasião da visita, o sistema conhecido como "retardo Exel", que vem a ser um sucedâneo da "espoleta Mantinel" proposta inicialmente. Do mesmo modo, o recobrimento do cordel detonante com material fino deixou de ser necessário, uma vez que não se usava mais o cordel detonante (Foto 11).

10. A estação meteorológica proposta desde o início do processo e considerada imprescindível para evitar detonações com condições adversas não foi instalada em razão de seu alto custo. De acordo como os funcionários da empresa, os dados meteorológicos eram obtidos por telex ou telefone em estação meteorológica próxima. Em decorrência desta alteração de exigência, as medições na estação, com periodicidade diária, previstas no processo de AIA, nunca foram executadas.

11. Um convênio com a Cetesb para monitoramento da qualidade do ar foi substituído pela aquisição de um Hivol, com o qual foi conduzido um programa de monitoramento sistemático durante os três primeiros anos (duas vezes por semana), quando as medições passaram a ser feitas esporadicamente.

12. Embora previsto no processo de AIA como medida de implementação imediata, vários anos após a aprovação do EIA, o plantio de "espécies vegetais locais" em talude sujeito a erosão e escorregamentos limitava-se a algumas árvores, que se encontravam ainda mal desenvolvidas, e capim napier em meio a vegetação rasteira de crescimento espontâneo (Foto 12).

13. As medidas de início de recuperação das áreas, detalhadas em quatro itens no parecer do Daia, não estão sendo executadas pois são consideradas impraticáveis, um vez que existe apenas um grande 
anfiteatro e o trânsito de máquinas no local é contínuo. Segundo os funcionários que acompanharam a visita, não existe área onde se possa iniciar a recuperação.

14. Embora estabelecido no processo de AIA, não era feito registro permanente do histórico das atividades da mineração, acompanhamento dos dados obtidos pela da estação meteorológica e por análises de água efetuadas, bem como inventário florístico anual. Parte destas atividades havia sido executada nos primeiros anos para preparação de relatórios de monitoramento, que deixaram de ser apresentados.

15. Embora os procedimentos para a disposição do estéril tenham sido bastante detalhados nos vários documentos que compõem o processo de AIA, a mina não tem camada de estéril, seu capeamento, pouco espesso, é integralmente constituído de solo fértil, que é removido e disposto em leiras para aproveitamento posterior. As dimensões e os procedimentos definidos no processo de AIA são ignorados (Foto 13).

16. O sistema de tratamento de efluentes em lagoas de decantação foi modificado com a redução do número de lagoas, possibilitada pela introdução de um espessador (Foto 14).

17. Não é feito nenhum tipo de controle da poeira fugitiva nas pilhas de produto, tampouco aplicado qualquer produto que favoreça a formação de película superficial, como preconiza o parecer do Daia. Segundo seus funcionários, a empresa não considera significativa a emissão de poeira nesta fonte, em razão do isolamento da área.

18. O projeto de arborização, que previa cercas vivas e plantios isolados, com mudas obtidas no Instituto de Botânica de São Paulo, para mitigar a ocorrência de poeiras fugitivas, ruído e degradação visual da paisagem resume-se ao plantio de eucaliptos em quantidade e posicionamento claramente insuficiente e inadequado para os propósitos almejados (Foto 15).

19. O plantio de espécies regionais (o parecer do Daia define as espécies que seriam empregadas), agrupadas em maciços, que deveria funcionar como banco de sementes para a fase de recuperação das áreas exploradas, foi iniciado na época da implantação do empreendimento, mas nunca foi utilizado como banco de sementes. A empresa não conta com profissional da área agronômica ou florestal e considera esta medida ineficaz. Quando necessita de sementes de espécies nativas, adquire no mercado. O "viveiro de mudas nativas" exigido pelo Consema existe e serve para o armazenamento de mudas adquiridas no mercado.

20. O projeto de revegetação proposto no processo de AIA vem sendo implementado parcialmente, na medida em que coincide com os requisitos de uso futuro das áreas, ou seja, pastos. As técnicas empregadas não são necessariamente as descritas no parecer do Daia. Quanto às árvores nativas que deveriam suceder a vegetação rasteira, apenas algumas árvores isoladas foram plantadas.

21. O monitoramento da poeira é parcial. Os jarros de deposição de poeira sedimentável previstos no processo de AIA chegaram a ser instalados próximo à mata ciliar, mas não se mostraram funcionais, talvez por deficiência em sua operação. 
22. A pedreira produz, atualmente, cerca de três vezes a quantidade prevista no processo de AIA e as detonações para desmonte primário, além de ocorrerem duas vezes por semana em vez de uma, conforme previsto no processo de AIA, não obedecem a horários predeterminados e a população vizinha não é informada com antecedência sobre a freqüência e horário das detonações. De acordo com as declarações do engenheiro responsável, em pedreiras deste porte, não é possível manter uma programação regular de detonações.

23. A informação fornecida no processo de AIA acerca da inexistência de habitantes, edificações e pastagens num raio de $1 \mathrm{~km}$ não corresponde à realidade. $\mathrm{Na}$ verdade, existem habitantes e edificações muito mais próximas da área do empreendimento, porém pertencem ao proprietário da fazenda de quem a área da mina é arrendada (Foto 16).

24. Com relação ao sistema de drenagem das águas pluviais, previsto no processo de AIA, existem canaletas ao redor da área de lavra, porém estão obstruídas por falta de limpeza, e a lagoa de decantação nunca foi impermeabilizada segundo o método descrito no parecer do Daia (“fundo impermeabilizado por compactação de solo-cimento e recobrimento com lona plastificada de PVC"). Trata-se de uma lagoa de pequenas dimensões (aproximadamente $250 \mathrm{~m}^{2}$, por $2,5 \mathrm{~m}$ de profundidade), totalmente assoreada no momento da visita. As águas de drenagem superficial provenientes do pátio de britagem, classificação e expedição, assim como os efluentes da operação de lavagem da brita para expedição, não são conduzidos para a bacia de drenagem, mas fluem desordenadamente em direção ao córrego (Fotos 17, 18, 19, 20 e 21).

25. O monitoramento das detonações previsto no EIA foi feito durante um ano, porém a Cetesb não aceitou os dados e a empresa parou de monitorar. Apenas um relatório de monitoramento foi entregue, embora o Consema tenha exigido periodicidade anual (a mina foi licenciada há cerca de nove anos).

26. A oficina de manutenção dos veículos, a área de lavagem de máquinas e equipamentos, o escritório, o refeitório e os sanitários, que no projeto original estariam situados fora da área do empreendimento, na fazenda vizinha, foram construídos próximo à pedreira. Além de não constar do processo de AIA, estas áreas construídas não foram incluídas no processo de licenciamento da Cetesb. No dia da visita, a caixa separadora de óleos e graxas, instalada próximo da oficina e galpão para lavagem de máquinas e veículos, transbordava e o efluente misturava-se às águas de drenagem (Fotos 22 e 23).

No decorrer da visita, procurou-se, ainda, conhecer a opinião dos mineradores acerca do processo de AIA. Em um dos casos, constatou-se que o proprietário tinha um discurso bastante afinado com os cuidados com o meio ambiente, demonstrando conhecimento e preocupação com a questão no âmbito local e mundial. Embora crítico dos órgãos governamentais, que considerava burocráticos, e de suas exigências, muitas vezes descabidas, reconhecia a importância de sua atuação para coibir abusos e a degradação do meio ambiente. 
Em outros casos, aparentemente menos sensibilizados com as questões ambientais, os mineradores consideravam-se "vítimas" dos órgãos ambientais e adotavam atitude claramente reativa, executando as medidas ambientais somente quando exigidas pelos órgãos fiscalizadores (Cetesb e DEPRN). Além disso, o cumprimento das exigências era apenas "burocrático", ou seja, beneficiando-se da falta de especificação detalhada, as medidas são executadas não para atingir os objetivos de mitigação originais, mas para possibilitar o registro de atendimento nos laudos de inspeção. Com a falta de atuação do DEPRN, as medidas relativas à cobertura vegetal foram muitas vezes abandonadas.

Na opinião de um dos entrevistados, o empreendimento era bem conduzido do ponto de vista ambiental (apesar de terem sido notadas numerosas irregularidades) e as dificuldades encontradas para sua regularização perante os órgãos ambientais decorriam de incompetência e má fé dos técnicos destes órgãos, que não estariam dando orientação segura e constante ao empreendedor a respeito de suas obrigações.

Na opinião de alguns dos representantes dos mineradores, a Cetesb, em razão do processo de AIA, vinha sendo muito mais exigente com a empresa do que com seus concorrentes que já estavam instalados no entorno. A fiscalização era mais intensa e a Cetesb mais presente, porém não aplicava aos demais o mesmo padrão de controle exigido da empresa. Portanto, o processo de AIA teria feito diferença, mas apenas na empresa, não influindo no padrão local de atuação da Cetesb. 
Capítulo 6

\section{AS DEFICIÊNCIAS NA ETAPA DE ACOMPANHAMENTO: SUAS ORIGENS E CAMINHOS PARA O APRIMORAMENTO}

Confirmando amplamente as expectativas que motivaram a realização da pesquisa, sua última etapa, visita às minas, revelou numerosas evidências de que as condições estabelecidas no processo de AIA para aprovação dos projetos propostos não foram, de modo geral, satisfatoriamente cumpridas nas fases de instalação e operação dos empreendimentos.

As características dos empreendimentos reais freqüentemente não correspondiam às descritas nos documentos técnicos, apresentando diferenças em parâmetros como volume de produção, área ocupada, arranjo espacial dos elementos da mina, processo de extração ou beneficiamento do minério, equipamentos etc. Muitas das medidas mitigadoras previstas não haviam sido implantadas ou sua implantação destinara-se apenas a cumprir formalmente as exigências, ou seja, visavam não aos objetivos de mitigação originais, mas a possibilitar o registro de atendimento nos laudos de inspeção. Esta situação - execução pro forma de medidas ambientais - repetiu-se várias vezes, principalmente em questões relacionadas à cobertura vegetal.

Diferenças entre o projeto aprovado e sua implementação têm sido constatadas com freqüência por vários estudiosos da aplicação da AIA em todo o mundo e constituem um dos fortes argumentos empregados na defesa do fortalecimento da etapa de acompanhamento. ARTS (1998) analisou vários estudos sobre a implementação da AIA e chama a atenção para o fato de que são raros os casos em que os impactos ambientais são reavaliados à luz da experiência, após a instalação do projeto. Do mesmo modo, modificações introduzidas nos projetos aprovados raramente são objeto de consulta às partes interessadas.

Constatou-se, ainda, nesta pesquisa, que os programas de monitoramento ambiental, quando implementados, eram conduzidos apenas para atender a exigências formais e seus dados utilizados exclusivamente para a elaboração de relatórios 
destinados aos órgãos ambientais. Estes dados, que poderiam ser utilizados pela própria empresa para identificar impactos não previstos, verificar a eficiência dos sistemas de controle de poluição e fundamentar ações corretivas, não eram sequer conhecidos pelos responsáveis pela operação das minas. Estes profissionais, de modo geral, simplesmente ignoravam os documentos técnicos do processo de AIA - EIA, Rima, complementações —, assim como o conjunto de medidas mitigadoras propostas, ou mesmo as características do projeto aprovado.

Os mineradores, ou seus representantes, mesmo aqueles que demonstraram sensibilidade com relação às questões ambientais, eram críticos com relação à atuação dos órgãos ambientais, considerando-os no mínimo burocráticos e ineficientes. Colocando-se como "vítimas" destes órgãos, adotavam atitude claramente reativa, ou seja, executavam as medidas ambientais apenas quando exigidas pelos órgãos fiscalizadores. Ademais, entendiam que o fato de terem sido submetidos ao processo de AIA os tornara alvo preferencial da fiscalização e que as exigências a eles impostas não eram estendidas às demais mineradoras da região, colocando-os em desvantagem competitiva em relação a estas.

As razões que determinaram esta situação podem ser localizadas, em um primeiro momento, nas deficiências de atuação dos órgãos fiscalizadores, que não são capazes de garantir o cumprimento dos termos e condições estabelecidos na aprovação do EIA. Este diagnóstico condiz com o padrão arraigado na administração pública brasileira, segundo o qual "o poder público obedece a uma estratégia pouco efetiva: identifica problemas ambientais e institui dispositivos legais para solucioná-los, mas pouca atenção dispensa aos mecanismos que garantam os resultados almejados" (GUIMARÃES et al., 1997). A análise detalhada das diversas etapas do processo de AIA, no entanto, revela uma cadeia de imperfeições que atinge praticamente todas as etapas do processo.

\subsection{Etapa de acompanhamento}

O processo de AIA envolve questões que, ultrapassando os limites do controle da poluiçãa do ar, da água e do solo, incluem a avaliação dos impactos ambientais sobre os meios físico, biológico e antrópico. Por esta razão, a realização do EIA e sua análise técnica são tarefas para equipes multidisciplinares. Até a etapa de decisão, esta característica da AIA é reconhecida e participam do processo, além do Daia, com suas 
equipes multidisciplinares, diversos órgãos de governo, como o Consema, a Cetesb, o Dusm e o DEPRN, cuja atuação é analisada com destaque nos capítulos iniciais. Estes órgãos, apesar de integrarem a estrutura da Secretaria do Meio Ambiente, já existiam antes da criação da SMA e a ela se juntaram, formando um mosaico com suas missões, prioridades, corpo técnico e procedimentos desenvolvidos e cristalizados em diferentes graus. GEORGE (2000) observa que é comum em países de média e baixa renda que o órgão encarregado da condução do processo de AIA tenha sido criado recentemente e suas responsabilidades estejam maldelimitadas, superpondo-se com as de outros órgãos.

Na etapa pós-decisão, a pesquisa revelou que a tarefa de acompanhamento da implementação dos projetos aprovados ficou praticamente a cargo da Cetesb, com registros de atuação episódica do Daia e do DEPRN. Considerando que muitas das medidas mitigadoras e de monitoramento estabelecidas nos vários processos tratavam de assuntos da esfera de competência do DEPRN, a falta de atuação sistemática deste órgão pode explicar a acentuada negligência com que foram tratadas as medidas mitigadoras relacionadas à vegetação.

Quanto à Cetesb, sua participação nas etapas que antecedem a decisão no processo de AIA é restrita. Se e quando consultada, emite pareceres técnicos a respeito de aspectos de sua competência e participa da decisão final na condição de membro do Consema. Não foram encontradas evidências de participação sistemática e abrangente da Cetesb na análise técnica do EIA, no exame das medidas mitigadoras e de monitoramento propostas ou na formulação de novas medidas, na forma de exigências.

Deste modo, além de concentrar praticamente toda a atividade de fiscalização do empreendimento, o que inclui vários aspectos alheios à prevenção e controle da poluição, tais como vegetação, higiene e segurança do trabalho, impactos socioeconômicos da atividade etc., mesmo dentro de sua área de competência, a Cetesb enfrenta dificuldades nesta empreitada, já que nem sempre seus técnicos estão de acordo com os termos e compromissos definidos no processo de AIA. De modo geral, a Cetesb procura incorporar os condicionantes do processo de AIA às exigências da LI ou da LF, porém destaca apenas algumas e contempla as demais por meio de formulações abrangentes do tipo - "a empresa deverá cumprir as demais exigências constantes da deliberação do Consema". 
Com relação às medidas que destaca ou mesmo a outras, nos trâmites processuais subseqüentes a Cetesb reformula, adapta, suprime ou acrescenta detalhes, dispensa ou substitui propostas, ajustando a decisão do processo de AIA aos seus padrões e critérios de importância. Ao mesmo tempo, abandona gradativamente a cobrança de medidas fora de sua área de competência e concentra sua atuação nos aspectos abrangidos pela Lei Estadual nº 997/76 e seu regulamento, ou seja, poluição do ar, da água e do solo, com especial ênfase em questões objeto de queixas da população.

Esta atitude levou a equiparar os empreendimentos submetidos ao processo de AIA aos mesmos padrões de fiscalização aplicados aos demais. Em alguns casos, questões que haviam recebido grande atenção durante o processo de AIA acabaram simplesmente abandonadas — não implantadas e não exigidas — enquanto outras, consideradas importantes pela Cetesb, seja por motivo de reclamações de vizinhos, seja por critérios técnicos próprios, foram acompanhadas cuidadosamente, mesmo figurando sem nenhum destaque nos documentos da AIA.

Problemas relacionados à transferência de responsabilidades nas muitas etapas da AIA e à fragmentação das competências administrativas entre diversos órgãos de governo são apontados por vários autores. No Canadá, por exemplo, as atividades de acompanhamento são, em muitos casos, repassadas para o processo de licenciamento depois de aprovado o EIA (WLODARCZYC, 2000). Ao comparar cinco sistemas de AIA nos Estados Unidos (EUA), Europa e Austrália, HOLLICK (1981) observa que a responsabilidade pela verificação da conformidade entre os projetos aprovados e sua implementação é fragmentada entre numerosas autoridades, resultando em sobreposição e conflitos entre órgãos de governo, bem como falhas, pois alguns fatores não são de responsabilidade direta de nenhum órgão. Além disso, cada órgão reavalia o desempenho do projeto sob seu ponto de vista, mas não ocorre a reavaliação integrada de todos os aspectos, a exemplo do que sucede no processo de AIA. Ao que tudo indica, nessas jurisdições, as principais atividades de acompanhamento também se restringem ao controle da poluição do ar, da água, do solo e sonora. Sobre outros temas, dependem de pressão da população sobre os órgãos do governo ou de ações na justiça.

A alegação dos técnicos, de que não dispõem de instrumentos jurídicos e administrativos para exigir o cumprimento das medidas preconizadas no EIA quando estas não se enquadram nas normas e regulamentos, provavelmente não resiste à análise 
de especialistas na matéria, mas reflete a realidade da fiscalização. Afinal, o fato de os técnicos encarregados da fiscalização não se julgarem competentes para garantir o cumprimento dos compromissos, já é razão suficiente para prejudicar a priori sua atuação. Este aspecto, a insuficiência ou inadequação de instrumentos jurídicos e administrativos para garantir o cumprimento das condições fixadas no processo de AIA, é particularmente recorrente na análise de eficácia dos diversos sistemas. Nos EUA, por exemplo, o judiciário chegou a manifestar-se considerando o EIA um documento meramente informativo, não exigível (HOLLICK, 1981). Para superar este problema, o Council on Environmental Quality criou um documento legalmente exigível denominado "Record of Decision (ROD)", que, segundo o autor citado, enumera as medidas mitigadoras, o programa de monitoramento e a emissão de relatórios periódicos. Conforme destaca McCALLUM (1987), apesar de sua importância, as atividades de acompanhamento da implementação de projetos submetidos à AIA, na ausência de mecanismos de exigência mais eficazes, são conduzidas por meio de persuasão.

Outro ponto que compromete a atuação da Cetesb na etapa de acompanhamento refere-se ao conhecimento, ou à falta deste, do conjunto de condições fixadas no processo de AIA. Embora todos os documentos técnicos do processo - EIA, Rima, complementações, parecer do Daia e deliberação do Consema —, sejam regularmente encaminhados às regionais da Cetesb, esta fundamenta sua atuação apenas nos dois últimos, que são incorporados ao processo de licenciamento. Ou seja, a Cetesb fiscaliza no máximo o cumprimento das medidas apresentadas no parecer do Daia e na deliberação do Consema, quando não se limita ao texto desta última.

Ora, o parecer do Daia e a deliberação do Consema não refletem as conclusões do processo de maneira completa e, portanto, não são documentos hábeis para nortear a fiscalização. Ademais, apresentam os mesmos problemas de formulação observados nos demais documentos de AIA. De modo geral, exigências formuladas pela Cetesb são mais precisas, referenciam-se a parâmetros mensuráveis e estão associadas a padrões de emissão ou de qualidade ambiental, objeto de normas e regulamentos. As medidas formuladas no processo de AIA, por outro lado, são vagas e imprecisas e requerem interpretação e avaliações subjetivas por parte dos agentes de fiscalização, ficando, deste modo, sujeitas a controvérsias e contestações. 
Mesmo não se transformando em realidade, as condições impostas na aprovação do EIA têm influência marcante no processo de licenciamento e são responsáveis, em grande medida, pelo alongamento dos prazos para concessão das licenças de instalação e de funcionamento. Conforme exposto no capítulo anterior, o tempo decorrido entre a aprovação do EIA e a emissão da licença de funcionamento variou de 20 a 109 meses nos casos estudados. A maior parte deste tempo foi consumida pelo proponente do projeto no atendimento às exigências formuladas pela Cetesb, parte delas oriundas do processo de AIA. A necessidade de ajustes e reformulação destas exigências, de modo a torná-las precisas e exequíiveis, a atitude reativa por parte do empreendedor, que somente implementava as medidas quando notificado ou ameaçado de multa ou paralisação de atividades, e a complacência ou omissão da Cetesb, que permitia o funcionamento de empreendimento sem as licenças devidas, são os fatores mais importantes que determinaram a dilatação dos prazos de concessão das licenças.

\subsection{A etapa de análise detalhada}

Esta etapa inclui, entre outras atividades, a elaboração do EIA e do Rima, sua análise técnica, a consulta pública e a decisão final. A elaboração dos termos de referência (TR) não é comentada em destaque nesta discussão porque na época em que os casos estudados foram submetidos ao processo de AIA, os procedimentos vigentes no Estado de São Paulo não incluíam a elaboração do TR. Em cada uma das outras etapas, no entanto, a pesquisa tornou possível a identificação de imperfeições que se refletem na etapa de acompanhamento.

\subsubsection{O EIA e o Rima}

O EIA é o principal documento técnico do processo e sua análise fundamenta o parecer do Daia sobre a viabilidade ambiental do empreendimento. O EIA contém a caracterização do empreendimento e do meio onde se pretende implantá-lo; a identificação, previsão e avaliação dos impactos ambientais prováveis; a proposição de medidas capazes de atenuar os impactos negativos e potencializar os positivos. Sua concepção, que encadeia informações, discussão e conclusões, é apropriada para subsidiar a tomada de decisões.

A forma de apresentação do EIA, no entanto, não pode ser considerada adequada para nortear a etapa de acompanhamento, pois os numerosos aspectos do projeto que 
asseguram sua viabilidade ambiental encontram-se dispersos nos vários itens do documento e sua formulação carece de precisão e detalhamento. É comum encontrar-se no item reservado à caracterização do empreendimento a descrição detalhada de medidas de caráter ambiental que, quando são reapresentadas nos itens apropriados, o são de forma resumida, sem o mesmo nível de detalhe.

A localização das informações no documento é importante, pois está estreitamente relacionada com o fluxo de informações, ou seja, somente as medidas apresentadas nos itens Medidas mitigadoras ou de monitoramento são transportadas para o parecer do Daia e daí para o processo de licenciamento da Cetesb. Enfim, informações contidas no item Caracterização do empreendimento na prática não chegam aos técnicos encarregados da fiscalização ou chegam de forma resumida.

Com relação à precisão de linguagem, observou-se que a maior parte das medidas propostas era formulada em linguagem vaga e imprecisa; muitas das proposições não poderiam sequer ser classificadas como medidas mitigadoras conquanto limitavam-se a expor critérios de projeto ou declarações de intenção genéricas; em alguns casos a apresentação era confusa, misturando a discussão do impacto com a apresentação da medida mitigadora. Apenas uma pequena parcela das medidas era dimensionada, ou seja, fixava parâmetros e limites quantitativos ou semiquantitativos, de modo a facilitar a verificação do seu cumprimento, reduzindo a necessidade de avaliações subjetivas por parte dos fiscais.

Algumas das medidas propostas no EIA extrapolavam a competência do proponente, ou seja, teriam de ser executadas por terceiros que não haviam sido consultados e, portanto, poderiam não concordar em executá-las.

Em alguns casos, as medidas eram apresentadas com detalhamento excessivo, fixando não somente o equipamento (marca e modelo) e local de implantação, como os procedimentos de operação. Tal detalhamento, embora apropriado para um documento guia da implementação do projeto, é inadequado para a fiscalização, uma vez que seu acompanhamento exigiria a presença do agente fiscal no momento da execução dos trabalhos. Além disso, ao fixar o equipamento (marca e modelo) ao invés do efeito esperado ou exigido, a adoção da melhor alternativa tecnológica em cada momento pode ficar prejudicada. 
A ênfase no emprego de determinadas tecnologias em detrimento da fixação de padrões de desempenho evita problemas que podem advir quando as medidas mitigadoras propostas não apresentam na prática a eficiência esperada. HOLLICK (1981) sustenta a idéia, no entanto, de que esta abordagem dificulta a atuação dos órgãos de fiscalização. Comparando estas duas abordagens, conformidade com relação ao projeto aprovado ou desempenho medido por meio de indicadores ambientais, ARTS et al. (2000) defendem a segunda, já que, ao final, não são os efeitos previstos, mas sim os reais que são relevantes para o meio ambiente.

Quanto ao Rima, em tese deveria ser redigido em linguagem acessível ao público em geral, porém, nos casos estudados constituía-se apenas em uma versão mutilada do EIA. As medidas ambientais propostas tinham ou formulação idêntica à do EIA, ou apresentavam supressão de parágrafos nos quais os procedimentos eram mais bem detalhados. Em um dos casos, o Rima apresentou medidas que não constavam do EIA. O acréscimo de medidas ambientais no Rima pode levar a uma distorção do processo, já que este documento não é utilizado pelas equipes técnicas em sua análise e, por conseguinte, tais medidas não influem na decisão e não são transportadas para o parecer do Daia ou para o processo de licenciamento. Deste modo, o público em geral recebe uma informação enganosa, ou seja, toma conhecimento de medidas que, na prática, ficam de fora do processo de decisão e da etapa de acompanhamento.

Em suma, o EIA e o Rima não são utilizados pelos técnicos responsáveis pela fiscalização da implementação do empreendimento e das medidas mitigadoras propostas, porém, se o fossem, exigiriam destes um trabalho de localização e interpretação de informações incompatível com o tempo de que dispõem para a tarefa e mesmo com o nível de preparo técnico que possuem.

O reconhecimento de que o EIA não é um documento adequado para nortear atividades de acompanhamento da implementação de projetos é quase uma unanimidade entre os autores dedicados ao tema. ARTS (1998), por exemplo, considera que os EIAs são, em geral, documentos descritivos e que as afirmações e previsões neles contidas são freqüentemente vagas, imprecisas, incompletas e pouco rigorosas. Esta característica decorre, em parte, do fato de que sempre existirão incertezas e lacunas de conhecimento na etapa de realização da AIA e tomada de decisão. McCALLUM (1987) afirma que a descrição dos projetos nos EIAs é muitas vezes incorreta ou incompleta e 
que modificações são introduzidas durante a construção. Ademais, as previsões feitas durante a avaliação são vagas e não verificáveis.

\subsubsection{A análise técnica}

A partir do exame dos estudos elaborados pelo proponente - o EIA e o Rima - , de vistoria ao local pretendido para o empreendimento e de consultas a outros órgãos do sistema, o Daia pode solicitar complementação dos estudos, alterações no projeto ou nas medidas mitigadoras, ou ainda formular exigências. A legislação prevê a possibilidade de consulta ao público nesta etapa, porém isso não ocorreu nos casos estudados. Mesmo assim, dada sua importância no processo de AIA, a questão da participação pública nesta etapa e em outras é comentada em item específico.

O atendimento às solicitações do Daia é consolidado em um relatório complementar. Este relatório normalmente é estruturado como um documento de resposta e contém alterações na concepção do projeto e das medidas mitigadoras. Além de trazer os mesmos problemas de linguagem observados no EIA na formulação das medidas mitigadoras, acentua o problema das medidas excessivamente detalhadas, que são mais freqüentes e evidentes.

Apesar de intitulados complementares, alguns destes relatórios apresentaram conteúdo nitidamente substitutivo, abordando aspectos já discutidos no EIA e reapresentando, modificadas ou não, as medidas ali propostas, além de formular novas. Mesmo assim, não foi registrado no processo administrativo correspondente que o relatório complementar substituía o EIA, permanecendo ambos válidos, o que contribuiu para aumentar a dificuldade de localização e interpretação dos condicionantes à aprovação do projeto.

As várias imperfeições presentes no EIA, no Rima e nas complementações poderiam ser corrigidas no parecer do Daia. Este documento é um registro da análise efetuada pela equipe técnica do Daia e de suas conclusões. Contém uma síntese dos dados fornecidos pelo proponente (nos vários documentos técnicos), o que inclui a caracterização do projeto, os impactos ambientais previstos e as medidas mitigadoras, de monitoramento e de recuperação propostas. Além disso, o parecer apresenta informações obtidas em vistorias ou consultas a outros órgãos, propõe, sob a designação de exigências, novas medidas ambientais como condicionantes à aprovação do projeto e 
emite um juízo de valor acerca da viabilidade ambiental do empreendimento. Nos casos estudados, recomenda sua aprovação pelo Consema.

De modo geral, os pareceres do Daia não foram capazes de reproduzir ordenadamente as medidas ambientais propostas pelo empreendedor, tendo apresentado numerosas falhas na transmissão de informações, tais como: omissão, total ou parcial, de medidas; distorção do seu conteúdo; acréscimo de detalhes ou mesmo medidas novas apresentadas como sendo de autoria do proponente; supressão de detalhes de dimensionamento das medidas, tornando-as mais imprecisas etc. Em alguns casos, os textos fazem referências a mapas, plantas ou mesmo explanações contidas no EIA ou no relatório complementar, porém não os incorpora ao parecer na forma de anexos e estas informações acabam não chegando aos agentes fiscais. Em suma, ao resumir as propostas, o parecer do Daia empobrece o texto, torna-o mais confuso e ainda menos adequado para nortear as atividades de fiscalização.

Também com relação às exigências introduzidas pelo Daia, além dos problemas de formulação já comentados para as medidas propostas pelo empreendedor, ocorrem outros como a inclusão, sob esta designação, de manifestações de preocupação com determinadas questões, reafirmação de procedimentos vigentes ou definição de atribuições. Além disso, é no mínimo questionável a inclusão, neste momento, de medidas que podem não ser tecnicamente viáveis ou implicar custos excessivos para o empreendimento. Considerando que a partir deste momento o proponente não tem mais a oportunidade de discutir a viabilidade técnica e econômica da medida, ou de contrapor argumentos que provem que a mesma não é necessária ou pode ser substituída por outra com vantagens, a imposição de novas exigências pode gerar problemas nas etapas seguintes, particularmente durante o acompanhamento da implantação do projeto.

\subsubsection{Consulta pública}

A participação pública é uma das marcas características do processo de AIA, podendo ser considerada como o grande diferencial entre este e o licenciamento simples. No Estado de São Paulo, as possibilidades de participação pública foram ampliadas com a edição da Resolução SMA nº 42/94 que possibilitou a solicitação de audiências públicas também na fase de aprovação dos termos de referência. $\mathrm{Na}$ época em que tramitaram os processos estudados nesta pesquisa, entretanto, as audiências públicas eram realizadas somente na etapa de análise técnica, para subsidiá-la, e desde 
que solicitadas nos termos da lei. Nenhum dos casos estudados foi objeto de audiência pública.

Esta não é uma exceção no cenário da aplicação dos procedimentos de AIA ao setor mineral no Estado de São Paulo. Das 51 audiências públicas (FERRER, 1998) realizadas desde a implantação do processo no Estado, até dezembro de 1997, apenas três referiam-se a projetos de mineração, apesar da nítida predominância desses projetos entre os EIAs apresentados — 55,1\% no mesmo período (RONZA, 1998). Nos três casos o EIA tratava de situações que configuravam adensamento de empreendimentos em uma dada região, ou seja, nenhum dos EIAs simples, relativos a um único empreendimento, aprovados no período foi objeto de audiência pública, apesar de terem sido aprovados 72 EIAs de mineração nessa condição.

Deste modo, a participação pública no processo de AIA relativo à mineração no Estado de São Paulo restringiu-se, na maior parte dos casos, às reuniões do Consema, onde o público pode comparecer, mas não tem direito de voz e voto. Além de insuficiente, esta participação é sem dúvida tardia no processo, uma vez que as principais questões já estão definidas.

Este quadro se reflete na etapa de acompanhamento, pois as partes interessadas, em particular a população do entorno da área da mina, não só perdem a oportunidade de influir na decisão, como ficam privadas das informações relativas aos termos e compromissos assumidos pelo proponente. Esta grave deficiência, na prática, impede que o público interessado exerça seu papel na fiscalização, cobrando dos órgãos ambientais e do proponente o cumprimento dos compromissos assumidos.

\subsubsection{Decisão}

As deliberações do Consema, que registram as decisões tomadas pelos conselheiros, não contribuíram, nos casos estudados, para corrigir as imperfeições na transmissão de informações observadas ao longo do processo. Documentos concisos, em linguagem padronizada, limitam-se a aprovar o EIA/Rima com base no parecer do Daia, afirmando a obrigatoriedade de cumprir as medidas propostas no EIA/Rima. Algumas das deliberações analisadas sequer mencionam o EIA/Rima, limitando-se a exigir o cumprimento das medidas contidas no parecer do Daia. Não fazem menção aos relatórios complementares. Além das medidas propostas no EIA/Rima ou contidas no 
parecer do Daia, os conselheiros formulam novas exigências ou transformam recomendações do Daia em exigências.

A enumeração de algumas poucas exigências em um documento conciso como a deliberação do Consema confere destaque injustificável a questões nem sempre tão importantes. Com efeito, mesmo os estudos de impacto ambiental mais precários geralmente contemplam as questões mais importantes e, se não o fazem, a equipe encarregada da análise técnica corrige os rumos da avaliação ao solicitar estudos complementares ou propor alterações no projeto ou nas medidas ambientais. Assim, é lícito supor que as questões incluídas como exigências ou recomendações no parecer do Daia, eventualmente transformadas em exigências na deliberação do Consema, sejam no máximo um complemento, surgido, às vezes na própria reunião plenária do Conselho, sem discussão com as partes interessadas.

Enfim, pelo destaque recebido, as exigências enumeradas na deliberação do Consema, apesar de sua importância secundária, atraem a atenção dos órgãos de fiscalização em detrimento de questões mais substantivas e fundamentais.

\subsection{As etapas iniciais}

Embora a relação entre as imperfeições existentes nas etapas iniciais do processo de AIA e as constatadas na etapa de acompanhamento não seja tão evidente quanto nas demais etapas, este vínculo é determinante quando se propõem soluções para os problemas detectados. Falhas nos mecanismos de triagem foram responsáveis, em grande parte, pela forte predominância numérica de projetos de mineração entre os EIAs apresentados desde a implantação dos procedimentos de AIA no Estado. De fato, a proporção entre EIAs de mineração e de outras atividades — resíduos sólidos, sistemas de transporte, urbanização e lazer, atividades industriais, saneamento, energia, sistemas de drenagem, agropecuária - não condiz com o potencial de impactos ambientais associado aos projetos mineiros, especialmente tendo em vista as características da mineração no Estado de São Paulo.

Desde a regulamentação da AIA no Brasil pela Resolução Conama $n^{0}$ 1/86, a extração mineral foi incluída com destaque entre as atividades que deveriam ser objeto de estudo de impacto ambiental. Na verdade, naquele momento não havia triagem de 
projetos de mineração, a lista positiva da Resolução abrangia todos, "inclusive os da classe II, definida no Código de Mineração”.

A primeira norma editada no Estado de São Paulo (Resolução SMA no 18/89) ampliou mais ainda este universo, ao considerar que minerações em atividade sem as devidas licenças ambientais deveriam submeter-se ao processo de AIA para sua regularização perante os órgãos ambientais. Embora defensável sob certos enfoques, como o de não privilegiar empresas que se instalaram em desacordo com a legislação, a Resolução 18 acabou desvirtuando a aplicação do instrumento em sua essência, ou seja, seu caráter prévio. Caberiam, nesses casos, ações corretivas que poderiam ser exigidas no âmbito da aplicação de outros instrumentos de gestão, como auditoria ambiental ou sistema de gestão ambiental, ou por meio da exigência de outros documentos técnicos como o Prad, cujo escopo, tal como definido na citada Resolução SMA nº 18/89, além de abordar a recuperação final da área degradada, como indica sua denominação, trata do gerenciamento ambiental do empreendimento ao longo de sua vida útil remanescente.

Anos mais tarde, quando a avalanche de estudos de impacto ambiental de projetos de mineração já havia comprometido grande parte dos recursos humanos e de infra-estrutura disponíveis para análise técnica no Daia, alguns mecanismos de triagem começaram a ser praticados; primeiramente apoiados na legislação federal, que havia editado a Resolução Conama $n^{0}$ 10/90 criando a figura da dispensa de EIA/Rima, e depois em norma estadual, a Resolução SMA nº 26/93. O resultado foi um acentuado declínio do número de EIAs de mineração apresentado a cada ano, não somente em termos absolutos, mas também com relação às demais atividades.

A Resolução 26 fixou critérios para exigência de EIA/Rima de empreendimentos minerários que dependiam da avaliação inicial caso a caso, com aplicação do poder discricionário da autoridade ambiental, no caso o Daia, exceto para os empreendimentos considerados grandes. São considerados grandes os projetos cuja área a licenciar iguala ou supera 100 ha ou cuja produção iguala ou ultrapassa $5.000 \mathrm{~m}^{3} /$ mês. Estes critérios foram mantidos em sua essência nos regulamentos editados posteriormente, que trataram mais da articulação entre os órgãos do sistema.

Observando-se o perfil dos empreendimentos que tiveram EIA aprovado no período de janeiro de 1987 a dezembro de 1997, constata-se que a maior parte seria 
considerada grande pela definição da Resolução 26 e, por conseguinte, teria de submeter-se ao processo completo de AIA. Além disso, vários dispositivos, como o Decreto Federal n⿳0 750/93 e a Portaria Ibama nº 887/90, reduzem ainda mais o poder discricionário do órgão ambiental.

Editada recentemente, a Resolução SMA no 3/99 acrescentou um novo e importante critério de dispensa: projetos de mineração localizados em áreas definidas como zonas minerárias regularmente aprovadas. Ou seja, a exemplo do que já ocorre com os distritos industriais, submete-se a proposta de zoneamento minerário ao processo de AIA, que fixa diretrizes para o licenciamento dos empreendimentos, evitando-se a avaliação de impacto ambiental caso a caso.

\subsection{Caminhos para o aperfeiçoamento da etapa de acompanhamento}

Superar as deficiências da etapa de acompanhamento requer intervenções em várias das etapas do processo de AIA em duas frentes distintas e complementares: fortalecimento do processo completo de AIA e aprimoramento dos mecanismos de triagem. Em outras palavras, as etapas iniciais devem ser capazes de eleger para submissão ao processo completo de AIA apenas os projetos cujos impactos ambientais não puderem ser adequadamente gerenciados pelo licenciamento simples. Ou seja, a aplicação do processo completo de AIA deve ser a exceção, não a regra. Para os casos selecionados, entretanto, o processo tem de ser aprimorado, mesmo que isto implique a necessidade de alocação de maiores recursos humanos e de infra-estrutura dos órgãos ambientais.

\subsubsection{Fortalecimento do processo de AIA}

Grande parte dos problemas associados à localização de informações e precisão de linguagem na formulação das medidas ambientais pode ser solucionada com a criação de um documento de aprovação do projeto. Esse documento, a ser elaborado pela equipe técnica multidisciplinar do Daia e apresentado ao Consema juntamente com seu parecer sobre o empreendimento, deve conter os principais parâmetros de caracterização do projeto - área ocupada, produção, equipamentos e instalações, distribuição espacial expressa graficamente etc.- e a descrição de todas as medidas ambientais que devem ser implementadas para garantir a viabilidade ambiental do empreendimento, bem como a designação do órgão encarregado de sua fiscalização. 
Cada medida ambiental deve ser tratada como um compromisso, sua formulação deve ser clara, incluindo, sempre que possível, indicadores por meio dos quais possa ser verificado o seu cumprimento, assim como um cronograma.

AU; SANVICENS (1995), com base na experiência de Hong Kong, afirmam que o sucesso das ações de acompanhamento da implementação do projeto depende em grande medida de uma adequada tradução dos termos e compromissos estabelecidos no decorrer das várias etapas do processo de AIA. Antes de qualquer outra providência, é preciso que as condições para aprovação do projeto sejam claramente definidas e registradas em documento escrito. Na mesma direção, WLODARCZYK (2000), discutindo o sistema federal canadense, garante que a afirmação clara e explicitamente documentada dos compromissos para mitigação dos impactos ambientais conforme negociado e estabelecido no processo de AIA é pré-requisito imprescindível para o sucesso da etapa de acompanhamento.

GOODLAND; MERCIER (1999 apud GEORGE, 2000) sugerem, em uma abordagem mais radical, que o plano de gerenciamento ambiental, que contém a descrição de todas as ações relevantes a ser implementadas pelo proponente, incluindo o monitoramento dos impactos e a demonstração de capacidade de gerenciá-los desde a implantação do empreendimento até sua completa desativação, seja o documento principal de aprovação do empreendimento. Nestas condições, a previsão dos impactos ambientais e a demonstração da necessidade e adequação das medidas mitigadoras seriam parte de um anexo, útil principalmente para subsidiar a tomada de decisão.

Conforme mencionado anteriormente neste Capítulo, para superar a falta de suporte legal que facultasse à autoridade ambiental exigir a implementação das medidas de gerenciamento ambiental previstas no processo de AIA, a legislação dos EUA criou um documento legalmente exigível denominado "Record of Decision (ROD)".

A partir da aprovação do EIA e emissão da licença prévia, que deverá integrar esse documento de aprovação, é preciso garantir que todos os órgãos participantes da aprovação do projeto e das medidas ambientais, e não apenas a Cetesb, fiscalizem sua execução, cada um de acordo com suas atribuições. Embora o documento de aprovação contemple a designação do órgão ambiental encarregado da fiscalização de cada medida ambiental, o papel do Daia não pode se encerrar com a aprovação do projeto; sua 
atuação na coordenação da fiscalização e no tratamento de medidas que não se enquadram nas atribuições dos demais órgãos é imprescindível.

A participação — da Cetesb, DEPRN e demais órgãos — deve ser intensificada e ocorrer de forma sistemática e abrangente já nas fases anteriores à decisão, na análise e formulação final das medidas ambientais. Deste modo, eventuais divergências a respeito da concepção do projeto ou das medidas ambientais podem ser dirimidas na etapa de análise técnica, diminuindo a necessidade de adaptações posteriores à concessão da licença. Desde que justificadas, tais adaptações poderão ser feitas em comum acordo entre o órgão encarregado do acompanhamento da medida e o responsável pelo empreendimento, mas terão de ser comunicadas ao Daia e ao Consema, que poderão aceitá-las ou não. Tendo em vista que a AIA é baseada em concepções preliminares do projeto, que são detalhadas posteriormente, bem como em previsões de impacto ambiental com variados graus de incerteza, são necessárias provisões para alterações tanto do projeto como das medidas de gerenciamento ambiental, que poderão se revelar insuficientes ou pouco eficazes (HOLLICK, 1981; ARTS, 1998; GEORGE, 2000).

A introdução deste documento de aprovação deve ser acompanhada de provisão de sanções a ser aplicadas quando os compromissos estabelecidos não forem cumpridos. No caso de impactos abrangidos por legislação específica, como a de controle da poluição, as sanções previstas são em geral suficientes, mas na ausência destas, sanções específicas devem ser estabelecidas (GEORGE, 2000). Referindo-se à fiscalização do meio ambiente no Estado de São Paulo, GUIMARÃES et al. (1997) afirmam que "toda a experiência estrangeira alerta-nos no sentido de observar que a ausência de multas, penalidades, instrumentos de comprovação e avaliação de dano ambiental e de outros quesitos reduz acentuadamente a 'disposição' para cumprir-se a legislação”. As penalidades a que estão sujeitas as empresas que não cumprirem os compromissos definidos no processo de AIA devem ser expressamente definidas e divulgadas para conhecimento dos empreendedores e dos técnicos dos órgãos ambientais, em todos os níveis, mas especialmente aqueles envolvidos com atividades de fiscalização.

Desde o início do processo, na etapa de elaboração do EIA, a preocupação com a formulação dos compromissos deve estar presente. Em outras palavras, sem prejuízo da apresentação do projeto, do diagnóstico do meio proposto para sua implantação, da 
identificação, previsão e avaliação dos impactos e do plano de gestão, o EIA deve conter uma versão preliminar do documento de aprovação. Por ser dirigido a um público não-especializado, o Rima pode ser redigido em linguagem menos técnica, mas deve reproduzir, na íntegra, a versão preliminar do documento de aprovação, de modo a garantir uma base comum de informações objetivas para todos os interessados.

$\mathrm{Na}$ fase de análise técnica do EIA, todos os documentos emitidos pelo proponente do projeto - relatórios complementares —, ou pelos órgãos participantes da análise — solicitações de complementação ou exigências —, quando implicarem alterações nos compromissos definidos na versão preliminar do documento de aprovação, devem destacar esta condição formalizando propostas de inclusão, exclusão ou substituição de itens no referido documento.

Ainda na fase de análise técnica, a realização de audiência pública deve ser estendida a todos os projetos submetidos ao processo completo de AIA. Mais do que permitida ou tolerada, a participação pública deve ser estimulada como forma de transformar o público em um aliado na fiscalização do empreendimento. Para tanto, é necessário que uma versão atualizada do documento de aprovação, contendo as alterações acertadas entre o proponente e o órgão ambiental, seja divulgada em tempo hábil para conhecimento e compreensão por parte do público.

AUSTIN (2000) sustenta que a atividade de acompanhamento do processo de AIA, ao envolver as comunidades locais, representa, mais do que um exercício científico ou administrativo, uma oportunidade de melhoria do conhecimento e atenção da comunidade sobre o meio ambiente e sobre o projeto em si. AU; SANVICENS (1995) destacam que a eficácia do acompanhamento do processo de AIA cresce consideravelmente quando o envolvimento das comunidades afetadas é facilitado e estimulado. De acordo com GEORGE (2000), as ONGs e o público têm um papel valioso a desempenhar na etapa de acompanhamento, especialmente em países de média e baixa renda; mais do que permitir, os planos de gerenciamento têm de prever medidas de incentivo à participação do público.

O texto final do documento de aprovação deve ser encaminhado ao Consema juntamente com o parecer do Daia e todos os compromissos nele expressos devem ser conhecidos e aprovados pelo proponente e pelos órgãos encarregados da fiscalização. $\mathrm{Na}$ etapa de decisão final, exigências de última hora eventualmente formuladas por 
membros do Consema deverão ter definição de órgão responsável por sua fiscalização e somente poderão ser incluídas no documento de aprovação com anuência do proponente e do órgão fiscalizador.

\subsubsection{Aprimoramento dos mecanismos de triagem}

O fortalecimento do processo de AIA e da fiscalização de suas decisões tem de ser acompanhado do aprimoramento das etapas iniciais e do aperfeiçoamento do processo de licenciamento simples para o qual serão remetidos todos os projetos cujos impactos não forem considerados significativos ou passíveis de atenuação com a implementação de medidas mitigadoras de eficiência conhecida e comprovada.

Os procedimentos de AIA são complexos e o sucesso de sua aplicação exige pessoal altamente qualificado e recursos materiais expressivos. Se o processo for fortalecido e os mecanismos de triagem não forem aperfeiçoados, um número desnecessariamente alto de projetos de mineração continuará a ser submetido ao processo completo de AIA, sobrecarregando ainda mais os já escassos recursos humanos e materiais. Nessas condições, o objetivo de melhoria da qualidade da AIA dificilmente será atingido.

Os critérios de exigência de EIA para projetos de mineração de grande porte atualmente vigentes devem ser revistos, pois os parâmetros escolhidos — volume de produção e área da concessão mineral — não guardam, necessariamente, relação direta com o potencial do empreendimento de acarretar impactos ambientais. O limite de $5.000 \mathrm{~m}^{3}$ mensais define, principalmente para o setor de agregados, empreendimentos de pequeno ou médio porte, cujo potencial de causar impactos significativos está associado, fundamentalmente, à sua localização. Quanto à área da concessão mineral, por razões alheias aos procedimentos do licenciamento ambiental, esta não corresponde, na prática, à área afetada pelo empreendimento. Definir critérios taxativos com base nesse parâmetro implica exigir EIA da quase totalidade dos empreendimentos de mineração.

Ademais, os empreendimentos em operação sem as devidas licenças ambientais não devem ser submetidos ao processo de AIA, uma vez que esse instrumento de política ambiental tem caráter essencialmente preventivo, ou seja, presta-se a auxiliar a tomada de decisão de implantar ou não um projeto. Se o empreendimento já está em 
operação, há que se aplicar instrumentos de política ambiental apropriados para o controle ambiental da atividade e a recuperação das áreas. Para tanto, são necessárias alterações nas normas de aplicação dos procedimentos de AIA.

Contudo, para que a redução da parcela de empreendimentos submetida ao processo completo de AIA não implique prejuízos ao meio ambiente, é preciso que o processo de licenciamento simples seja aprimorado.

O caminho sinalizado pela Resolução SMA no 3/99, dispensar do processo completo de AIA o licenciamento de empreendimentos em zonas minerárias devidamente aprovadas, é promissor desde que o licenciamento de tais zonas seja o resultado de uma avaliação de impactos ambientais cumulativos e defina diretrizes para o desenvolvimento da atividade.

Mesmo para empreendimentos não incluídos em zonas minerárias é urgente que padrões de operação sejam definidos ou aperfeiçoados. Em um primeiro momento, tais padrões podem ser extraídos das normas, regulamentos e práticas dos órgãos ambientais (Cetesb, DEPRN, Dusm), para em seguida, gradativamente, ser aprimorados com base em estudos e pesquisas aplicadas.

A existência de diretrizes e padrões de operação aplicáveis aos tipos mais comuns de empreendimentos minerários implica um tratamento caso a caso, por meio do processo de AIA, apenas das questões relevantes não contempladas. Em outras palavras, um grande número de questões ambientais importantes pode e deve ser equacionado no âmbito do processo de licenciamento simples, reservando-se ao processo de AIA situações que dependam de juízo de valor. 


\section{CONCLUSÕES}

São inegáveis os benefícios associados à introdução da avaliação de impacto ambiental como instrumento da política nacional do meio ambiente no Brasil. Apesar de suas limitações, que emergiram à luz da experiência, a AIA possibilitou a integração dos múltiplos aspectos ambientais associados aos projetos de desenvolvimento e privilegiou, de maneira inédita no País, a participação pública no processo decisório.

Especificamente com relação aos projetos de mineração, a aplicação dos procedimentos de AIA como subsídio ao licenciamento ambiental, e por conseguinte à obtenção dos direitos minerários, logrou resgatar a preocupação com os interesses coletivos, até então submersos em meio ao emaranhado de leis, normas e regulamentos que regem o acesso aos bens minerais. $\mathrm{O}$ balanço entre os impactos ambientais positivos e negativos dos projetos, considerado o significado moderno do termo meio ambiente, que inclui aspectos socioeconômicos, abriu espaço para que a concessão de direitos minerários deixasse de ser o resultado natural de um processo burocrático e passasse a ser outorgada em benefício da sociedade.

O grande potencial representado pelo novo instrumento de política ambiental não foi, contudo, plenamente atingido em sua aplicação, como aliás sucede com grande parte das leis brasileiras: avançadas e meritórias em sua concepção, mas carentes de mecanismos para garantir sua efetividade. Nas diversos jurisdições onde a AIA foi introduzida, as primeiras análises de seus resultados focalizaram principalmente os aspectos metodológicos da previsão e avaliação de impactos, a qualidade dos estudos elaborados e os trâmites do processo de avaliação, em especial as etapas iniciais e a participação pública.

Mais recentemente, as atenções se voltaram para a etapa de acompanhamento da implantação dos projetos aprovados, que passou a ser considerada de importância crucial principalmente para: (i) a análise dos erros e acertos do processo de previsão e avaliação de impactos; (ii) a modificação ou concepção de novas medidas de 
gerenciamento dos efeitos adversos do projeto sobre o meio ambiente e (iii) a garantia do cumprimento dos termos e compromissos estabelecidos no processo. Este terceiro ponto é especialmente relevante no Brasil, tendo em vista os inúmeros exemplos de desobediência legal e não-cumprimento de obrigações que povoam a história e o cotidiano do País.

Esta foi, precisamente, a principal constatação proporcionada pela análise meticulosa da aplicação dos procedimentos de AIA a projetos de mineração no Estado de São Paulo: as condições estabelecidas para a aprovação dos projetos não são, de modo geral, satisfatoriamente cumpridas nas etapas de instalação e operação dos empreendimentos. A análise possibilitou, ainda, a identificação de numerosos pontos fracos e imperfeições desde as etapas iniciais do processo até as atividades de acompanhamento desenvolvidas posteriormente à aprovação do projeto.

Os critérios e procedimentos de triagem, inexistentes nos primeiros anos de aplicação, mesmo com as melhorias introduzidas a partir do início dos anos 90, ainda são inadequados para garantir que apenas os projetos potencialmente causadores de significativo impacto ambiental sejam submetidos ao processo completo de AIA. Ao contrário, além de empreendimentos cujos impactos potenciais não são significativos ou são passíveis de atenuação com a implementação de medidas mitigadoras de eficiência conhecida e consagrada, no Estado de São Paulo estão sujeitos ao processo completo de AIA também empreendimentos em operação, muitas vezes há vários anos, mas que apresentam situação irregular perante o órgão ambiental.

A principal consequiência das imperfeições existentes nos critérios e mecanismos de triagem é que um número desnecessariamente alto de projetos de mineração é submetido ao processo completo de AIA, consumindo grande parte dos escassos recursos humanos e materiais disponíveis no órgão ambiental. Como reação a este quadro, o órgão ambiental tem dispensado aos estudos de impacto ambiental de projetos de mineração um tratamento simplificado, negligenciando, principalmente, os aspectos relacionados à participação pública. Em outras palavras, muitos projetos de mineração passam por uma avaliação de impacto ambiental menor, apenas para cumprir as exigências da legislação.

Os estudos de impacto ambiental analisados, além de apresentarem deficiências de conteúdo, tanto na caracterização do projeto e do meio em que se pretende implantá- 
lo, como na identificação, previsão e avaliação dos impactos, têm graves problemas de organização e linguagem. São documentos descritivos, adequados, quando muito, a subsidiar a aprovação do projeto. Os numerosos aspectos do projeto e as medidas de gerenciamento que asseguram sua viabilidade ambiental encontram-se dispersos nos vários itens do documento e sua formulação carece de precisão e detalhamento. Além disso, ao longo da etapa de análise técnica, alterações e complementações são apresentadas, sem que um documento de consolidação seja elaborado.

Ao final das etapas de análise técnica e decisão, com o acréscimo de exigências sugeridas pela equipe técnica responsável ou formuladas por membros do Consema, o conhecimento detalhado das características do projeto e das medidas de gerenciamento ambiental aprovadas, essencial para nortear a etapa de acompanhamento da instalação e funcionamento do empreendimento, dependeria de um trabalho de pesquisa para o qual os profissionais encarregados não só não estão qualificados e treinados, como não dispõem do tempo necessário. Ademais, a falta de precisão na formulação das medidas exige dos agentes fiscais avaliações subjetivas, sujeitas a controvérsias e contestação.

Não bastassem estas dificuldades, na etapa pós-decisão, a tarefa de acompanhamento da implementação dos projetos aprovados é transferida para a Cetesb e, em menor escala, para o DEPRN. Estes órgãos têm participação restrita nas etapas anteriores e suas atribuições não abrangem a totalidade dos aspectos contemplados na avaliação de impacto ambiental. Ou seja, não têm uma visão integrada do projeto e não participaram da definição dos condicionantes para sua aprovação. Mesmo assim, são encarregados de fiscalizá-los.

Os instrumentos jurídicos e administrativos disponíveis para exigir o cumprimento das medidas preconizadas no EIA são tidos como insuficientes e inadequados pelos técnicos encarregados de sua aplicação, que apresentam uma atitude geral burocrática e legalista. De modo geral, procuram enquadrar os condicionantes emanados do processo de AIA nas leis e normas de proteção ao meio ambiente e só assim as exigem dos empreendedores. Ou seja, as medidas de gerenciamento realmente exigidas poderiam sê-lo independentemente do processo de AIA.

Ademais, os órgãos fiscalizadores, por padecerem de uma falta de recursos humanos e materiais crônica, elegem suas prioridades para atuação principalmente com base em reclamações do público, que, conforme já comentado, praticamente não 
participa no processo de AIA de empreendimentos de mineração no Estado de São Paulo. Deste modo, as comunidades afetadas pelo projeto desconhecem os condicionantes estabelecidos para a sua aprovação e não têm como exercer seu papel na etapa de acompanhamento da instalação e operação.

Vários caminhos poderiam ser sugeridos para o aperfeiçoamento da etapa de acompanhamento, com vistas a assegurar que os condicionantes à aprovação do projeto, estabelecidos no processo de AIA sejam efetivamente respeitados. O mais óbvio deles é a injeção de recursos humanos e materiais nos órgãos encarregados da tarefa que, bem treinados e comprometidos com o intrumento, atuariam sob coordenação do Daia. Sem prejuízo da defesa desta valorização dos órgãos ambientais do Estado de São Paulo, algumas idéias são lançadas para debate e aperfeiçoamento.

A superação das deficiências da etapa de acompanhamento requer intervenções em duas frentes distintas e complementares: aprimoramento dos mecanismos de triagem e fortalecimento do processo completo de AIA.

A etapa de triagem deve ser capaz de eleger para submissão ao processo completo de AIA apenas os projetos cujos impactos ambientais não puderem ser adequadamente gerenciados por meio do licenciamento simples. Para alcançar este objetivo, é necessário:

1) o desenvolvimento de diretrizes e padrões de operação aplicáveis aos tipos mais comuns de empreendimentos. Estas diretrizes e padrões de operação podem ser extraídos das normas, regulamentos e práticas dos órgãos ambientais (Cetesb, DEPRN, Dusm) em um primeiro momento e ser aprimorados com base em estudos e pesquisas aplicados.

2) reformular os critérios de exigência de EIA/Rima baseados em volume de produção e área da concessão mineral. O caminho da aplicação dos procedimentos de AIA para a definição de diretrizes para o desenvolvimento de projetos em zonas minerárias, já sinalizado pela Resolução SMA nº 3/99, é promissor neste sentido.

Para os casos selecionados para submissão ao processo completo de AIA, este deve ser aprimorado e a preocupação com a etapa de acompanhamento deve estar presente desde as primeiras atividades. Neste sentido, propõe-se que: 
1) o EIA inclua, em destaque, uma versão preliminar ou minuta do que, ao final das etapas de análise e decisão, irá transformar-se em documento de aprovação. Este documento deverá conter os principais parâmetros de caracterização do projeto área ocupada, produção, equipamentos e instalações, distribuição espacial expressa graficamente etc. - e a descrição de todas as medidas ambientais previstas para assegurar a viabilidade ambiental do empreendimento. A formulação das medidas deve ser clara e incluir, sempre que possível, indicadores por meio dos quais possa ser verificado seu cumprimento, além do cronograma de sua implantação.

2) ao longo da etapa de análise técnica, todas as alterações na concepção do projeto ou das medidas mitigadoras negociadas com o proponente sejam incorporadas à minuta do documento de aprovação na forma de inclusão, exclusão ou substituição de propostas.

3) a realização de audiência pública seja estendida a todos os projetos submetidos ao processo completo de AIA. Todos os esforços devem ser envidados para incentivar a participação pública, em especial das comunidades mais afetadas pelo empreendimento. Por ocasião da audiência pública, uma versão atualizada da minuta do documento de aprovação terá de ser divulgada em tempo hábil para conhecimento e compreensão pelas partes interessadas.

4) ao final da análise técnica, seja incorporado ao documento de aprovação a designação do órgão encarregado de sua fiscalização. Esta designação deve ser precedida de entendimentos com os órgãos de fiscalização, que devem auxiliar na formulação das medidas propostas. O texto final do documento deve ser encaminhado ao Consema juntamente com o parecer do Daia e seu conteúdo deve ser conhecido e aceito pelo proponente.

5) na etapa de decisão final, as exigências eventualmente acrescentadas por membros do Consema sejam formuladas seguindo os mesmos padrões definidos para o documento de aprovação, quais sejam: clareza e precisão, inclusão de indicadores para verificação do cumprimento, cronograma e órgão responsável pela fiscalização. As exigências de última hora, sugeridas na etapa de decisão final, somente poderão ser incluídas no documento de aprovação mediante anuência do proponente e do órgão fiscalizador, ambos representados na reunião final do Consema. 
O documento de aprovação pode constituir-se em um anexo às licenças de instalação e funcionamento ou pode assumir a forma de um contrato, firmado pelo órgão ambiental e pelo proponente. Em qualquer caso, devem ser estabelecidas sanções para o caso do não-cumprimento dos termos e compromissos enumerados.

Finalmente, é prudente que alterações nos procedimentos de AIA sejam implementadas em caráter experimental para somente então, com base nos resultados alcançados e efetuados os ajustes necessários, passarem a constituir-se em novos regulamentos. Esta precaução, sempre recomendável em um processo democrático, pode evitar a edição de novas normas e regulamentos imperfeitos ou inadequados, como tantos que já existem.

As idéias aqui expostas evidentemente carecem de detalhamento e devem ser objeto de discussões que envolvam as várias partes interessadas. De todo modo, constituem um ponto de partida para o aprimoramento dos procedimentos de AIA aplicados ao setor mineral paulista, especialmente com relação à etapa de acompanhamento da implantação e funcionamento dos projetos aprovados. Várias destas sugestões podem ser aplicadas também em outros tipos de empreendimentos, cujos problemas de acompanhamento, acredita-se, não diferem muito dos projetos de mineração.

Enfim, se o procedimentos não forem aperfeiçoados, de modo a garantir o cumprimento dos termos e compromissos definidos, bem como o aprendizado com os erros e acertos de cada caso, um poderoso instrumento de política ambiental poderá ficar desacreditado e converter-se em apenas mais um dos já numerosos entraves burocráticos que dificultam o acesso aos bens minerais no País, mas não são eficazes para assegurar que seu aproveitamento se dê em beneficio da sociedade. 


\section{ANEXOS}





\section{ANEXO A}

Modelo de ficha utilizada para o levantamento de dados sobre os EIAs de mineração aprovados no Estado de São Paulo desde 1996. 



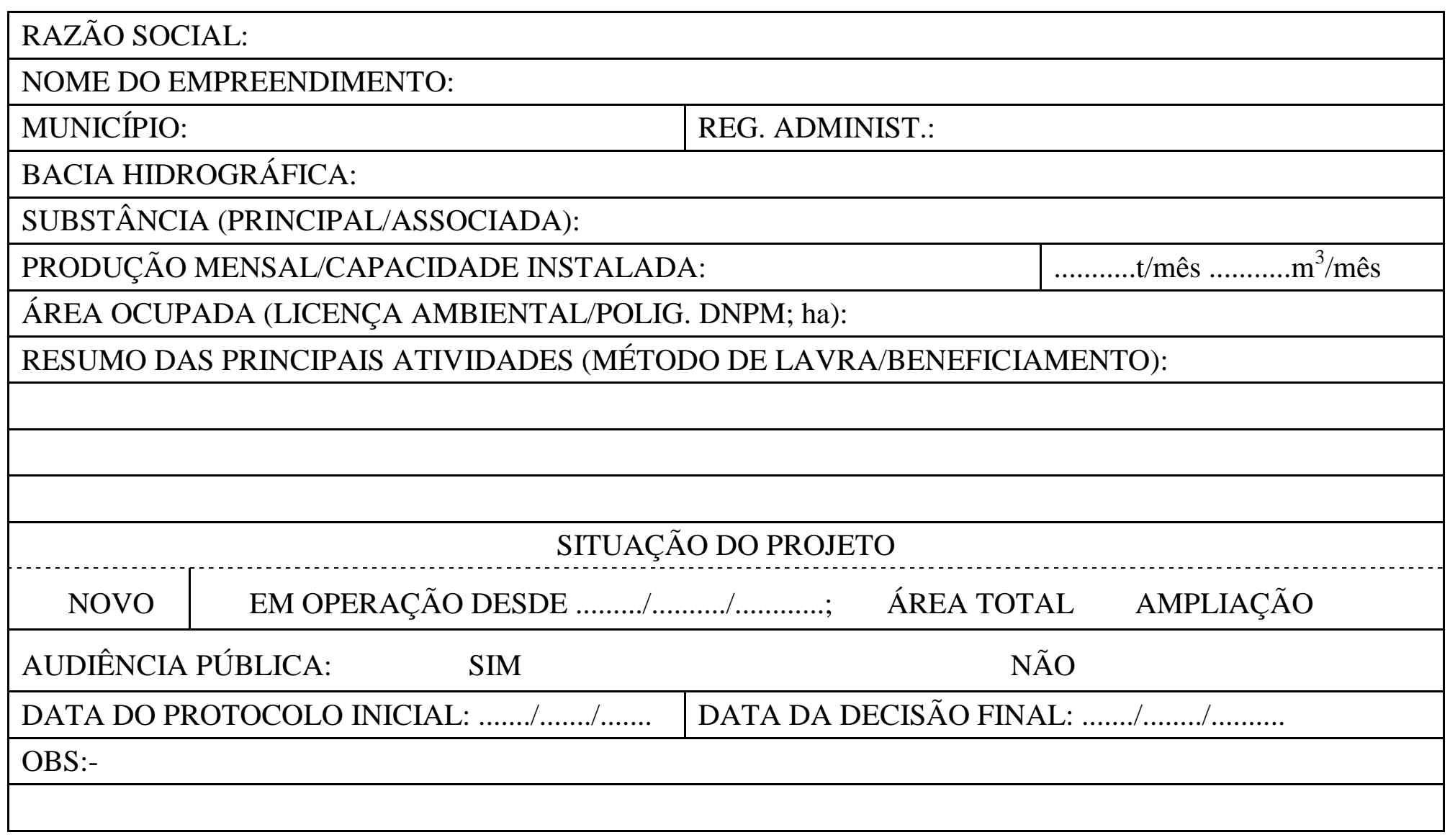





\section{ANEXO B}

Dados coletados sobre os EIAs de mineração aprovados no Estado de São Paulo desde 1996. 

Tabela 1: Evolução dos prazos de análise por data de aprovação

DATA DA ENTRADA

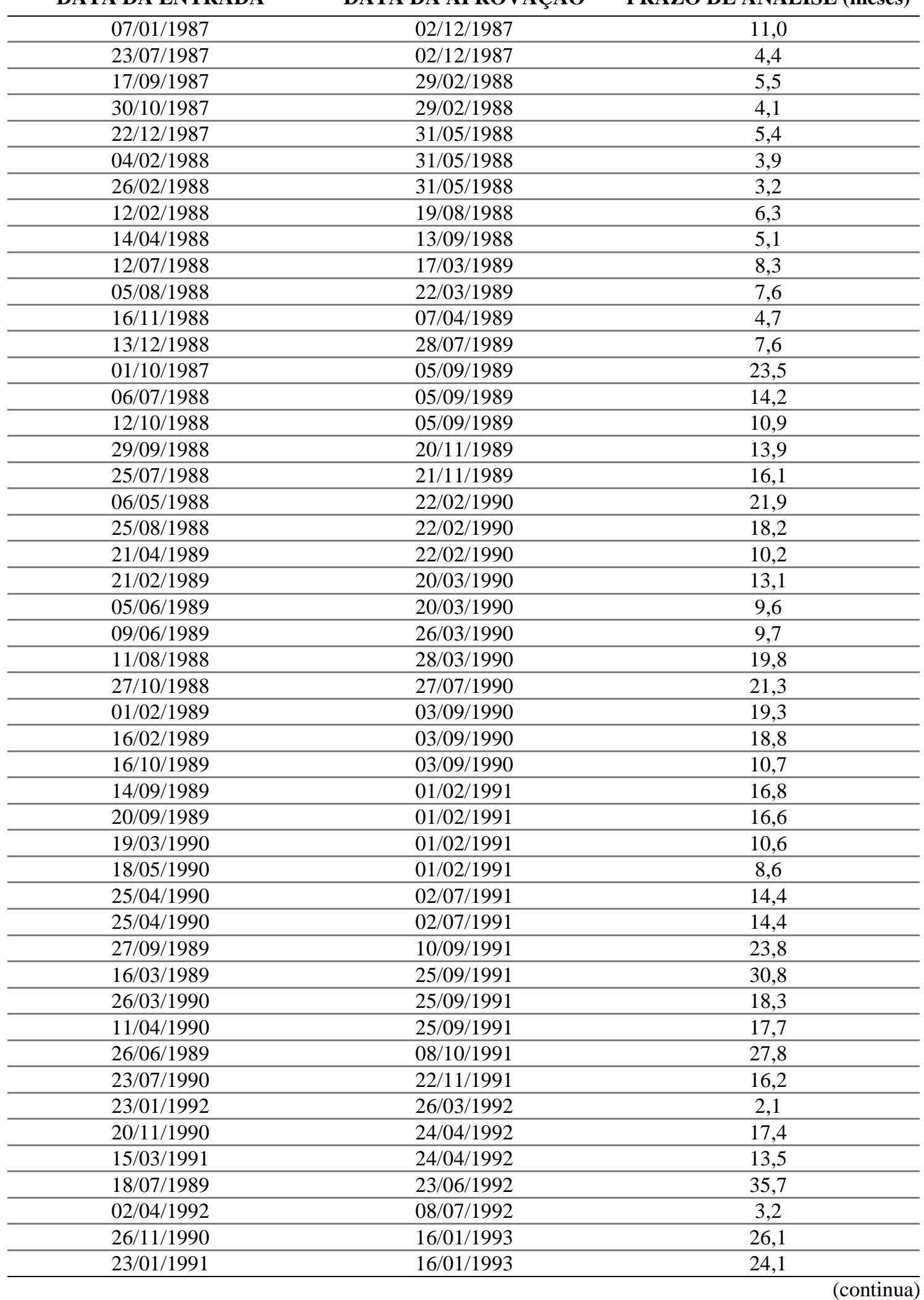


Tabela 1: Evolução dos prazos de análise por data de aprovação

(continuação)

\begin{tabular}{|c|c|c|}
\hline DATA DA ENTRADA & DATA DA APROVAÇÃO & PRAZO DE ANÁLISE (meses) \\
\hline 26/06/1991 & $11 / 02 / 1993$ & 19,9 \\
\hline 05/02/1992 & 29/03/1993 & 13,9 \\
\hline $20 / 02 / 1990$ & $07 / 07 / 1993$ & 41,1 \\
\hline $28 / 06 / 1990$ & 07/07/1993 & 36,8 \\
\hline $09 / 10 / 1990$ & 07/07/1993 & 33,4 \\
\hline 20/02/1991 & $07 / 07 / 1993$ & 28,9 \\
\hline $12 / 11 / 1992$ & $07 / 07 / 1993$ & 7,9 \\
\hline 06/04/1990 & 20/08/1993 & 41,1 \\
\hline $17 / 10 / 1990$ & $10 / 09 / 1993$ & 35,3 \\
\hline $19 / 12 / 1990$ & $10 / 09 / 1993$ & 33,2 \\
\hline 22/03/1991 & $10 / 09 / 1993$ & 30,1 \\
\hline $14 / 08 / 1991$ & $10 / 09 / 1993$ & 25,3 \\
\hline 07/01/1993 & $10 / 09 / 1993$ & 8,2 \\
\hline $13 / 01 / 1993$ & $10 / 09 / 1993$ & 8,0 \\
\hline $09 / 02 / 1993$ & $10 / 09 / 1993$ & 7,1 \\
\hline $18 / 04 / 1990$ & 29/09/1993 & 42,0 \\
\hline $15 / 06 / 1992$ & 28/01/1994 & 19,7 \\
\hline $30 / 10 / 1990$ & $09 / 02 / 1994$ & 39,9 \\
\hline 17/01/1990 & 15/09/1995 & 68,9 \\
\hline $07 / 06 / 1990$ & $15 / 09 / 1995$ & 64,2 \\
\hline $04 / 11 / 1992$ & $15 / 09 / 1995$ & 34,8 \\
\hline $23 / 06 / 1989$ & $30 / 10 / 1995$ & 77,3 \\
\hline $14 / 05 / 1990$ & $30 / 10 / 1995$ & 66,5 \\
\hline $06 / 12 / 1990$ & $30 / 10 / 1995$ & 59,6 \\
\hline $02 / 04 / 1992$ & $30 / 10 / 1995$ & 43,5 \\
\hline $21 / 11 / 1993$ & $09 / 04 / 1996$ & 29,0 \\
\hline $19 / 12 / 1991$ & $02 / 07 / 1996$ & 55,2 \\
\hline $10 / 08 / 1994$ & $10 / 12 / 1996$ & 28,4 \\
\hline $21 / 10 / 1993$ & $22 / 04 / 1997$ & 42,6 \\
\hline
\end{tabular}


Tabela 2: EIAs aprovados; por substância e localização

\begin{tabular}{|c|c|c|c|c|}
\hline ORDEM & SUBSTÂNCIA PRINCIPAL & №/MINAS & MUNICÍPIO & $\begin{array}{c}\text { REG. } \\
\text { ADMINISTRATIVA }\end{array}$ \\
\hline 65 & AREIA P/ CONSTRUÇÃO & 45 & AGUAÍ & CAMPINAS \\
\hline 32 & AREIA P/ CONSTRUÇÃO & 1 & ARARAS & CAMPINAS \\
\hline 51 & AREIA P/ CONSTRUÇÃO & 1 & CHARQUEADA & CAMPINAS \\
\hline 14 & AREIA PI CONSTRUÇÃO & 1 & LOUVEIRA & CAMPINAS \\
\hline 30 & AREIA P/ CONSTRUÇÃO & 1 & RINCÃO & CENTRAL \\
\hline 38 & AREIA P/ CONSTRUÇÃO & 2 & PIRASSUNUNGA & LIMEIRA \\
\hline 3 & AREIA PI CONSTRUÇÃO & 1 & SETE BARRAS & REGISTRO \\
\hline 33 & AREIA P/ CONSTRUÇÃO & 1 & SÃO SIMÃO & RIBEIRÃO PRETO \\
\hline 2 & AREIA P/ CONSTRUÇÃO & 1 & GUARULHOS & RMSP \\
\hline 49 & AREIA P/ CONSTRUÇÃO & 1 & GUARULHOS & RMSP \\
\hline 18 & AREIA P/ CONSTRUÇÃO & 1 & ITAPECERICA DA SERRA & RMSP \\
\hline 54 & AREIA P/ CONSTRUÇÃO & 1 & MOGI DAS CRUZES & RMSP \\
\hline 31 & AREIA P/ CONSTRUÇÃO & 1 & MOGI DAS CRUZES & RMSP \\
\hline 16 & AREIA P/ CONSTRUÇÃO & 1 & MOGI DAS CRUZES & RMSP \\
\hline 35 & AREIA P/ CONSTRUÇÃO & 1 & BERTIOGA/SANTOS & SANTOS \\
\hline 5 & AREIA P/ CONSTRUÇÃO & 1 & CUBATÃO & SANTOS \\
\hline 62 & AREIA P/ CONSTRUÇÃO & 1 & MONTE APRAZÍVEL & S. J. DO RIO PRETO \\
\hline 34 & AREIA P/ CONSTRUÇÃO & 1 & NOVA GRANADA/ICÉM & S. J. DO RIO PRETO \\
\hline 7 & AREIA P/ CONSTRUÇÃO & 1 & CAÇAPAVA & S. J. DOS CAMPOS \\
\hline 6 & AREIA P/ CONSTRUÇÃO & 1 & CAÇAPAVA & S. J. DOS CAMPOS \\
\hline 36 & AREIA P/ CONSTRUÇÃO & 1 & CAÇAPAVA & S. J. DOS CAMPOS \\
\hline 27 & AREIA P/ CONSTRUÇÃO & 1 & CAÇAPAVA & S. J. DOS CAMPOS \\
\hline 44 & AREIA P/ CONSTRUÇÃO & 1 & CAÇAPAVA & S. J. DOS CAMPOS \\
\hline 13 & AREIA PI CONSTRUÇÃO & 1 & CARAGUATATUBA & S. J. DOS CAMPOS \\
\hline 67 & AREIA P/ CONSTRUÇÃO & 1 & JACAREÍ & S. J. DOS CAMPOS \\
\hline 26 & AREIA P/ CONSTRUÇÃO & 22 & JACAREÍ & S. J. DOS CAMPOS \\
\hline 42 & AREIA P/ CONSTRUÇÃO & 1 & JACAREÍ & S. J. DOS CAMPOS \\
\hline 43 & AREIA P/ CONSTRUÇÃO & 1 & PINDAMONHANGABA & S. J. DOS CAMPOS \\
\hline 47 & AREIA P/ CONSTRUÇÃO & 1 & SÃO JOSÉ DOS CAMPOS & S. J. DOS CAMPOS \\
\hline 45 & AREIA P/ CONSTRUÇÃO & 1 & TAUBATÉ & S. J. DOS CAMPOS \\
\hline 41 & AREIA P/ CONSTRUÇÃO & 1 & TAUBATÉ & S. J. DOS CAMPOS \\
\hline 9 & AREIA P/ CONSTRUÇÃO & 2 & TAUBATÉ/CAÇAPAVA & S. J. DOS CAMPOS \\
\hline 52 & AREIA P/ CONSTRUÇÃO & 1 & TREMEMBÉ & S. J. DOS CAMPOS \\
\hline 57 & AREIA P/ CONSTRUÇÃO & 1 & TREMEMBÉ & S. J. DOS CAMPOS \\
\hline 61 & AREIA P/ CONSTRUÇÃO & 1 & TREMEMBÉ & S. J. DOS CAMPOS \\
\hline 76 & AREIA P/ CONSTRUÇÃO & 13 & ARAÇARIGUAMA & SOROCABA \\
\hline
\end{tabular}


Tabela 2: EIAs aprovados; por substância e localização

\begin{tabular}{|c|c|c|c|c|}
\hline ORDEM & SUBSTÂNCIA PRINCIPAL & №/MINAS & MUNICÍPIO & $\begin{array}{c}\text { REG. } \\
\text { ADMINISTRATIVA }\end{array}$ \\
\hline 69 & BRITA - BASALTO & 1 & JAÚ & BAURU \\
\hline 23 & BRITA - BASALTO & 1 & AMERICANA & CAMPINAS \\
\hline 68 & BRITA - BASALTO & 1 & PARAGUAÇU PAULISTA & MARÍLIA \\
\hline 50 & BRITA - BASALTO & 1 & JARDINÓPOLIS & RIBEIRÃO PRETO \\
\hline 71 & BRITA - DIABÁSIO & 1 & RIO CLARO & CAMPINAS \\
\hline 70 & BRITA - DIABÁSIO & 1 & SANTA BÁRBARA D'OESTE & CAMPINAS \\
\hline 55 & BRITA - DIABÁSIO & 1 & LIMEIRA & LIMEIRA \\
\hline 25 & BRITA - DIABÁSIO & 1 & PORTO FELIZ & SOROCABA \\
\hline 74 & BRITA - GRANITO & 1 & CAJATI & REGISTRO \\
\hline 73 & BRITA - GRANITO & 1 & JUQUIÁ & REGISTRO \\
\hline 75 & BRITA - GRANITO & 1 & MIRACATU & REGISTRO \\
\hline 10 & BRITA - GRANITO & 1 & ARUJÁ & RMSP \\
\hline 12 & BRITA - GRANITO & 1 & ARUJÁ & RMSP \\
\hline 4 & BRITA - GRANITO & 1 & CAIEIRAS & RMSP \\
\hline 22 & BRITA - GRANITO & 1 & GUARULHOS & RMSP \\
\hline 53 & BRITA - GRANITO & 1 & GUARULHOS & RMSP \\
\hline 40 & BRITA - GRANITO & 1 & GUARULHOS & RMSP \\
\hline 24 & BRITA - GRANITO & 1 & SANTA ISABEL & RMSP \\
\hline 21 & BRITA - GRANITO & 1 & IGARATÁ & S. J. DOS CAMPOS \\
\hline 63 & PEDRA DE TALHE & 1 & SANTA CLARA D'OESTE & S. J. DO RIO PRETO \\
\hline 19 & AREIA INDUSTRIAL & 1 & ANALÂNDIA & CAMPINAS \\
\hline 15 & AREIA INDUSTRIAL & 1 & ANALÂNDIA & CAMPINAS \\
\hline 28 & AREIA INDUSTRIAL & 1 & DESCALVADO & CENTRAL \\
\hline 39 & AREIA INDUSTRIAL & 1 & DESCALVADO & CENTRAL \\
\hline 29 & AREIA INDUSTRIAL & 1 & DESCALVADO & CENTRAL \\
\hline 1 & AREIA INDUSTRIAL & 1 & CAMPOS DO JORDÃO & S. J. DOS CAMPOS \\
\hline 37 & QUARTZITO & 1 & PIRAPORA DO BOM JESUS & RMSP \\
\hline 11 & QUARTZITO INDUSTRIAL & 1 & SÃO BENTO DO SAPUCAÍ & S. J. DOS CAMPOS \\
\hline 60 & ARGILA BENTONÍTICA & 1 & PINDAMONHANGABA & S. J. DOS CAMPOS \\
\hline 59 & ARGILA BENTONÍTICA & 1 & TAUBATÉ & S. J. DOS CAMPOS \\
\hline 64 & ARGILA P/ CERÂMICA & 1 & MOGI MIRIM & CAMPINAS \\
\hline 77 & ARGILA P/ CERÂMICA & 1 & MOGI MIRIM & CAMPINAS \\
\hline 56 & ARGILA REFRATÁRIA & 1 & SALEZÓPOLIS & RMSP \\
\hline 8 & ARGILA VERMELHA & 1 & JACAREÍ & S. J. DOS CAMPOS \\
\hline 72 & ARGILA VERMELHA & 1 & SOROCABA & SOROCABA \\
\hline 46 & CALCÁRIO DOLOMÍTICO & 1 & BONSUCESSO DO ITARARÉ & SOROCABA \\
\hline 66 & CALCÁRIO DOLOMÍTICO & 1 & RIBEIRÃO BRANCO & SOROCABA \\
\hline 58 & GRANITO ORNAMENTAL & 1 & CAMPINAS & CAMPINAS \\
\hline 20 & MÁRMORE ORNAMENTAL & 1 & BARRA DO TURVO & REGISTRO \\
\hline 17 & TURFA & 1 & SÃO JOSÉ DOS CAMPOS & S. J. DOS CAMPOS \\
\hline 48 & BAUXITA METÁLICA & 1 & DIVINOLÂNDIA & CAMPINAS \\
\hline
\end{tabular}


Tabela 3: EIAs de areia para construção civil por método de lavra e produção

\begin{tabular}{|c|c|c|c|}
\hline ORDEM & №/MINAS & PRODUÇÃO MENSAL & MÉTODO DE LAVRA \\
\hline 2 & 1 & $3.125 \mathrm{~m} 3 / \mathrm{mês}$ & DESMONTE HIDRÁULICO \\
\hline 54 & 1 & $5.000 \mathrm{~m} 3 / \mathrm{mês}$ & DESMONTE HIDRÁULICO \\
\hline 31 & 1 & $5.615 \mathrm{~m} 3 / \mathrm{mês}$ & DESMONTE HIDRÁULICO \\
\hline 49 & 1 & $5.833 \mathrm{m3} / \mathrm{mês}$ & DESMONTE HIDRÁULICO \\
\hline 18 & 1 & $6.000 \mathrm{~m} 3 / \mathrm{mês}$ & DESMONTE HIDRÁULICO \\
\hline 16 & 1 & $15.000 \mathrm{~m} 3 / \mathrm{mês}$ & DESMONTE HIDRÁULICO E DRAGAGEM EM CAVA INUNDADA \\
\hline 76 & 13 & & DESMONTE HIDRÁULICO \\
\hline 42 & 1 & & DESMONTE HIDRÁULICO \\
\hline 6 & 1 & $5.000 \mathrm{~m} 3 / \mathrm{mês}$ & DRAGAGEM EM CAVA INUNDADA \\
\hline 52 & 1 & $5.000 \mathrm{~m} 3 / \mathrm{mês}$ & DRAGAGEM EM CAVA INUNDADA \\
\hline 36 & 1 & $6.000 \mathrm{~m} 3 / \mathrm{mês}$ & DRAGAGEM EM CAVA INUNDADA \\
\hline 27 & 1 & $11.250 \mathrm{~m} 3 / \mathrm{mês}$ & DRAGAGEM EM CAVA INUNDADA \\
\hline 44 & 1 & 12.000 m3/mês & DRAGAGEM EM CAVA INUNDADA \\
\hline 45 & 1 & $12.000 \mathrm{~m} 3 / \mathrm{mês}$ & DRAGAGEM EM CAVA INUNDADA \\
\hline 47 & 1 & $16.000 \mathrm{~m} 3 / \mathrm{mês}$ & DRAGAGEM EM CAVA INUNDADA \\
\hline 43 & 1 & $20.000 \mathrm{~m} 3 / \mathrm{mês}$ & DRAGAGEM EM CAVA INUNDADA \\
\hline 61 & 1 & $20.000 \mathrm{~m} 3 / \mathrm{mês}$ & DRAGAGEM EM CAVA INUNDADA E NO LEITO DO RIO \\
\hline 41 & 1 & $25.000 \mathrm{~m} 3 / \mathrm{mês}$ & DRAGAGEM EM CAVA INUNDADA \\
\hline 67 & 1 & 34.740 m3/mês & DRAGAGEM EM CAVA INUNDADA \\
\hline 26 & 22 & & DRAGAGEM EM CAVA INUNDADA (18)/EM LEITO DE RIO (1)/DESMONTE HIDRÁULICO (3) \\
\hline 51 & 1 & $600 \mathrm{m3} / \mathrm{mês}$ & DRAGAGEM EM LEITO DE RIO \\
\hline 13 & 1 & $1.000 \mathrm{~m} 3 / \mathrm{mês}$ & DRAGAGEM EM LEITO DE RIO \\
\hline 7 & 1 & $3.300 \mathrm{~m} 3 / \mathrm{mês}$ & DRAGAGEM EM LEITO DE RIO \\
\hline 38 & 2 & $3.500 \mathrm{m3} / \mathrm{mês}$ & DRAGAGEM EM LEITO DE RIO \\
\hline 62 & 1 & $3.750 \mathrm{~m} 3 / \mathrm{mês}$ & DRAGAGEM EM LEITO DE RIO \\
\hline 3 & 1 & $4.400 \mathrm{~m} 3 / \mathrm{mês}$ & DRAGAGEM EM LEITO DE RIO \\
\hline 30 & 1 & $6.000 \mathrm{m3} / \mathrm{mês}$ & DRAGAGEM EM LEITO DE RIO \\
\hline 32 & 1 & $7.200 \mathrm{~m} 3 / \mathrm{mês}$ & DRAGAGEM EM LEITO DE RIO \\
\hline 35 & 1 & $10.000 \mathrm{~m} 3 / \mathrm{mês}$ & DRAGAGEM EM LEITO DE RIO \\
\hline 34 & 1 & & DRAGAGEM EM LEITO DE RIO \\
\hline 57 & 1 & $6.000 \mathrm{~m} 3 / \mathrm{mês}$ & DRAGAGEM EM LEITO DE RIO E EM CAVA INUNDADA NA VÁRZEA \\
\hline 9 & 2 & $12.000 \mathrm{~m} 3 / \mathrm{mês}$ & DRAGAGEM EM LEITO DE RIO E EM CAVA INUNDADA NA VÁRZEA \\
\hline 5 & 1 & $12.500 \mathrm{~m} 3 / \mathrm{mês}$ & DRAGAGEM EM LEITO DE RIO E EM DIQUES DO DAEE C/ ESCAVADEIRA OU DRAG-LINE \\
\hline 65 & 45 & & DRAGAGEM EM LEITO DE RIO \\
\hline 33 & 1 & $1.000 \mathrm{m3} / \mathrm{mês}$ & ESCAVAÇÃO MECANIZADA \\
\hline 14 & 1 & $9.270 \mathrm{m3} / \mathrm{mês}$ & ESCAVAÇÃO MECANIZADA \\
\hline
\end{tabular}


Tabela 4: EIAs de brita e pedra de talhe por método de lavra e produção

\begin{tabular}{|c|c|c|c|c|}
\hline ORDEM & №/MINAS & SUBSTÂNCIA PRINCIPAL & PRODUÇÃO MENSAL & MÉTODO DE LAVRA \\
\hline 63 & 1 & BASALTO P/ PEDRA DE TALHE & $40.000 \mathrm{~m} 3 / \mathrm{mês}$ & $\begin{array}{l}\text { C.A., AMARROAMENTO OU } \\
\text { FOGO SECUNDÁRIO }\end{array}$ \\
\hline 50 & 1 & BRITA - BASALTO & $5.500 \mathrm{~m} 3 / \mathrm{mês}$ & C.A. C/ EXPL.; BRIT.; CLASSIF. \\
\hline 69 & 1 & BRITA - BASALTO & $8.500 \mathrm{~m} 3 / \mathrm{mês}$ & C.A. C/ EXPL.; BRIT.; CLASSIF. \\
\hline 68 & 1 & BRITA - BASALTO & 9.750 m3/mês & C.A. C/ EXPL.; BRIT.; CLASSIF. \\
\hline 23 & 1 & BRITA - BASALTO & $10.000 \mathrm{~m} 3 / \mathrm{mês}$ & C.A. C/ EXPL.; BRIT.; CLASSIF. \\
\hline 71 & 1 & BRITA - DIABÁSIO & 8.000 m3/mês & C.A. C/ EXPL.; BRIT.; CLASSIF. \\
\hline 55 & 1 & BRITA - DIABÁSIO & $10.000 \mathrm{~m} 3 / \mathrm{mês}$ & C.A. C/ EXPL.; BRIT.; CLASSIF. \\
\hline 70 & 1 & BRITA - DIABÁSIO & $12.000 \mathrm{~m} 3 / \mathrm{mês}$ & C.A. C/ EXPL.; BRIT.; CLASSIF. \\
\hline 25 & 1 & BRITA - DIABÁSIO & $25.200 \mathrm{~m} 3 / \mathrm{mês}$ & C.A. C/ EXPL.; BRIT.; CLASSIF. \\
\hline 75 & 1 & BRITA - GRANITO & $6.500 \mathrm{~m} 3 / \mathrm{mês}$ & C.A. C/ EXPL.; BRIT.; CLASSIF. \\
\hline 74 & 1 & BRITA - GRANITO & 8.450 m3/mês & C.A. C/ EXPL.; BRIT.; CLASSIF. \\
\hline 73 & 1 & BRITA - GRANITO & 9.100 m3/mês & C.A. C/ EXPL.; BRIT.; CLASSIF. \\
\hline 22 & 1 & BRITA - GRANITO & $10.000 \mathrm{~m} 3 / \mathrm{mês}$ & C.A. C/ EXPL.; BRIT.; CLASSIF. \\
\hline 10 & 1 & BRITA - GRANITO & $15.000 \mathrm{~m} 3 / \mathrm{mês}$ & C.A. C/ EXPL.; BRIT.; CLASSIF. \\
\hline 21 & 1 & BRITA - GRANITO & $17.200 \mathrm{~m} 3 / \mathrm{mês}$ & C.A. C/ EXPL.; BRIT.; CLASSIF. \\
\hline 24 & 1 & BRITA - GRANITO & $50.000 \mathrm{~m} 3 / \mathrm{mês}$ & C.A. C/ EXPL.; BRIT.; CLASSIF. \\
\hline 53 & 1 & BRITA - GRANITO & $53.800 \mathrm{~m} 3 / \mathrm{mês}$ & C.A. C/ EXPL.; BRIT.; CLASSIF. \\
\hline 40 & 1 & BRITA - GRANITO & $57.000 \mathrm{~m} 3 / \mathrm{mês}$ & C.A. C/ EXPL.; BRIT.; CLASSIF. \\
\hline 12 & 1 & BRITA - GRANITO & $80.000 \mathrm{~m} 3 / \mathrm{mês}$ & C.A. C/ EXPL.; BRIT.; CLASSIF. \\
\hline 4 & 1 & BRITA - GRANITO & 110.000 m3/mês & C.A. C/ EXPL.; BRIT.; CLASSIF. \\
\hline
\end{tabular}

Tabela 5: EIAs de outras substâncias por método de lavra e produção

\begin{tabular}{cclcl}
\hline ORDEM & No/MINAS & \multicolumn{1}{c}{ SUBSTÂNCIA PRINCIPAL } & PROD. MENSAL & \multicolumn{1}{c}{ MÉTODO DE LAVRA } \\
\hline 11 & 1 & QUARTZITO INDUSTRIAL & $2.500 \mathrm{t} / \mathrm{mês}$ & C.A. C/ EXPL.; BRIT.; CLASSIF. \\
\hline 37 & 1 & QUARTZITO & $10.000 \mathrm{t} / \mathrm{mês}$ & ESCAVAÇÃO MECANIZADA \\
\hline 28 & 1 & AREIA INDUSTRIAL & $12.500 \mathrm{t} / \mathrm{mês}$ & ESCAVAÇÃO MECANIZADA \\
\hline 39 & 1 & AREIA INDUSTRIAL & $20.000 \mathrm{t} / \mathrm{mês}$ & ESC. MEC./DESM. HIDR. \\
\hline 19 & 1 & AREIA INDUSTRIAL & $20.000 \mathrm{t} / \mathrm{mês}$ & ESC. MEC./DESLAM./SEC. \\
\hline 1 & 1 & AREIA INDUSTRIAL & $30.000 \mathrm{t} / \mathrm{mês}$ & ESCAVAÇÃO MECANIZADA \\
\hline 15 & 1 & AREIA INDUSTRIAL & $30.000 \mathrm{t} / \mathrm{mês}$ & ESC. MEC./DESLAM./SEC. \\
\hline 29 & 1 & AREIA INDUSTRIAL & $100.000 \mathrm{t} / \mathrm{mês}$ & ESC. MEC./DESLAM./SEC. \\
\hline 60 & 1 & ARGILA BENTONÍTICA & $1.400 \mathrm{t} / \mathrm{mês}$ & ESCAVAÇÃO MECANIZADA \\
\hline 59 & 1 & ARGILA BENTONÍTICA & $666 \mathrm{t} / \mathrm{mês}$ & ESCAVAÇÃO MECANIZADA \\
\hline 64 & 1 & ARGILA P/ CERÂMICA & $2.500 \mathrm{t} / \mathrm{mês}$ & C.A., EM TIRAS, C/RETROESC. \\
\hline 77 & 1 & ARGILA P/ CERÂMICA & $2.500 \mathrm{t} / \mathrm{mês}$ & C.A., EM TIRAS, C/RETROESC. \\
\hline 56 & 1 & ARGILA REFRATÁRIA & $3.333 \mathrm{t} / \mathrm{mês}$ & ESCAVAÇÃO MECANIZADA \\
\hline 72 & 1 & ARGILA VERMELHA & $3.000 \mathrm{t} / \mathrm{mês}$ & ESCAVAÇÃO MECANIZADA \\
\hline 8 & 1 & ARGILA VERMELHA & $750 \mathrm{~m} 3 / \mathrm{mês}$ & ESC. MEC./SEC./QUEIMA \\
\hline 66 & 1 & CALCÁRIO DOLOMÍTICO & $30.000 \mathrm{t} / \mathrm{mês}$ & C.A. C/ EXPL.; BRIT.; CLASSIF.; \\
\hline 46 & 1 & CALCÁRIO DOLOMÍTICO & $6.000 \mathrm{t} / \mathrm{mês}$ & C.A./EXPL;BRIT;MOAG;CLAS.. \\
\hline 58 & 1 & GRANITO ORNAMENTAL & $250 \mathrm{~m} 3 / \mathrm{mês}$ & C/ EXPL. (PÓLVORA) \\
\hline 20 & 1 & MÁRMORE ORNAMENTAL & $100 \mathrm{~m} 3 / \mathrm{mês}$ & C/ FIO ABRASIVO \\
\hline 17 & 1 & TURFA & $5.611 \mathrm{~m} 3 / \mathrm{mês}$ & ESC MEC/EXTRUSÃO/SEC. NAT. \\
\hline 48 & 1 & BAUXITA METÁLICA & $7.000 \mathrm{t} / \mathrm{mês}$ & ESCAVAÇÃO MECANIZADA \\
\hline
\end{tabular}




\section{ANEXO C}

Roteiro e ficha para coleta de dados. 



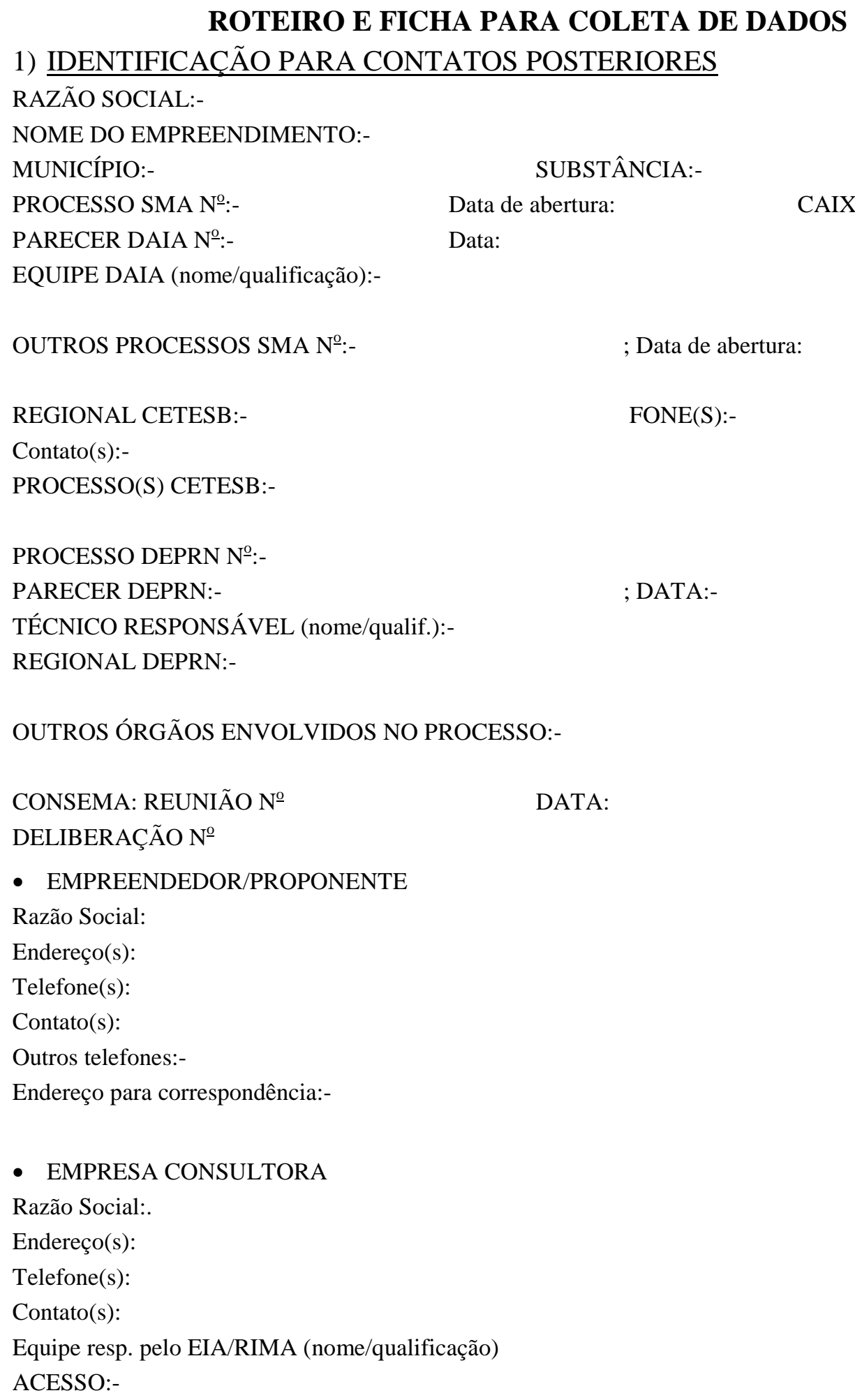


-238 -

2) DOCUMENTOS CONSULTADOS (nº de referência; localização; conteúdo e apresentação) Ex:- EIA/Rima, complementações, parecer Daia, parecer DEPRN, Ibama, Condephaat, atas de audiências públicas, atas de reuniões Consema, deliberação Consema, pareceres jurídicos, pareceres técnicos, relatórios de vistoria, manifestações do público em geral (vizinhos, observadores etc.). No caso do EIA, Rima, Complementações etc., anotar $\mathrm{n}^{\mathrm{o}}$ de volumes, páginas, figuras, plantas, mapas, quadros...... Copiar sumário. 
3) PRECEDENTES (identificação dos eventos que precederam à protocolização do EIA/Rima, existência de termo de referência, EIA/Rima anterior devolvido ou reprovado, RCA, PCA, PRAD)

4) MOTIVAÇÃO (origem da exigência de apresentação e aprovação do EIA/Rima: exigência DNPM, convênio Cetesb/Eletropaulo, atuação de rotina da Cetesb, atuação de rotina do DEPRN/Polícia Florestal, iniciativa do proponente ou consultor, Ministério Público, Prefeitura)

5) CRONOLOGIA DO PROCESSO (desde as primeiras iniciativas até a decisão do Consema, obtenção de LI e LF) 
6) CARACTERIZAÇÃO DO EMPREENDIMENTO APROVADO NO PROCESSO DE AIA (com base no EIA/Rima, complementações, parecer Daia, deliberação Consema, processo Cetesb e vistoria)

SUBSTÂNCIA (PRINCIPAL/ASSOCIADA):PRODUÇÃO MENSAL:CAPACIDADE INSTALADA:ÁREA OCUPADA:-

MÉTODO DE LAVRA:-

MÉTODO DE BENEFICIAMENTO:-

OUTRAS OPERAÇÕES:-

DISPOSIÇÃO DE ESTÉREIS E REJEITOS:-

ESCOAMENTO DA PRODUÇÃO:-

CAPTAÇÃO DE ÁGUA LIMPA:-

JORNADA DE TRABALHO:- 
7) MEDIDAS MITIGADORAS E DE MONITORAMENTO PROPOSTAS E SUA LOCALIZAÇÃO NOS DOCUMENTOS.

7.1) EIA

\begin{tabular}{|c|c|c|}
\hline MEDIDAS MITIGADORAS E DE MONITORAMENTO & ITEM & OBS. \\
\hline & & \\
\hline & & \\
\hline & & \\
\hline & & \\
\hline & & \\
\hline & & \\
\hline & & \\
\hline & & \\
\hline & & \\
\hline & & \\
\hline & & \\
\hline & & \\
\hline & & \\
\hline & & \\
\hline & & \\
\hline & & \\
\hline & & \\
\hline & & \\
\hline & & \\
\hline & & \\
\hline & & \\
\hline & & \\
\hline & & \\
\hline & & \\
\hline & & \\
\hline
\end{tabular}


7.2) RIMA

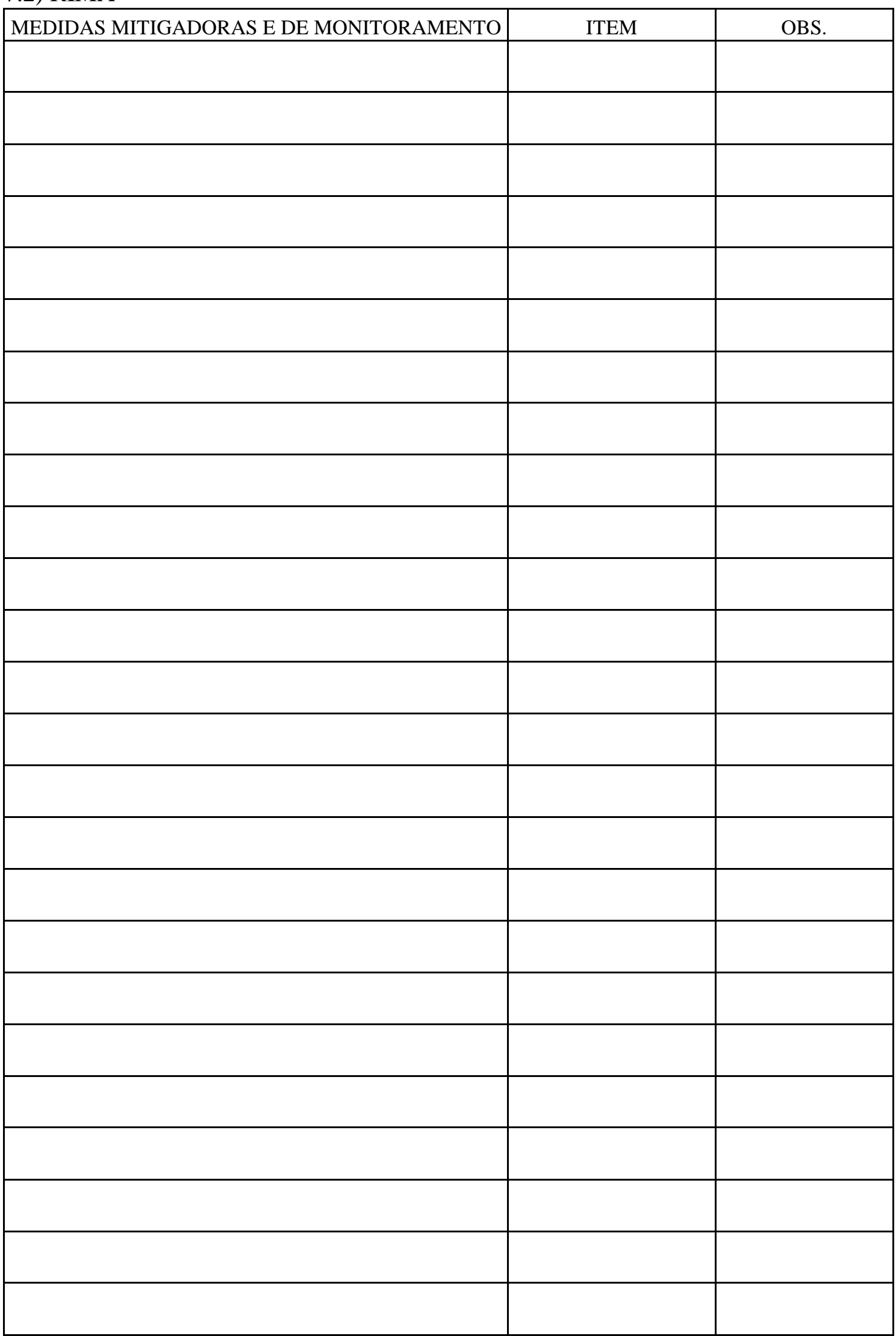




\section{3) COMPLEMENTAÇÕES}

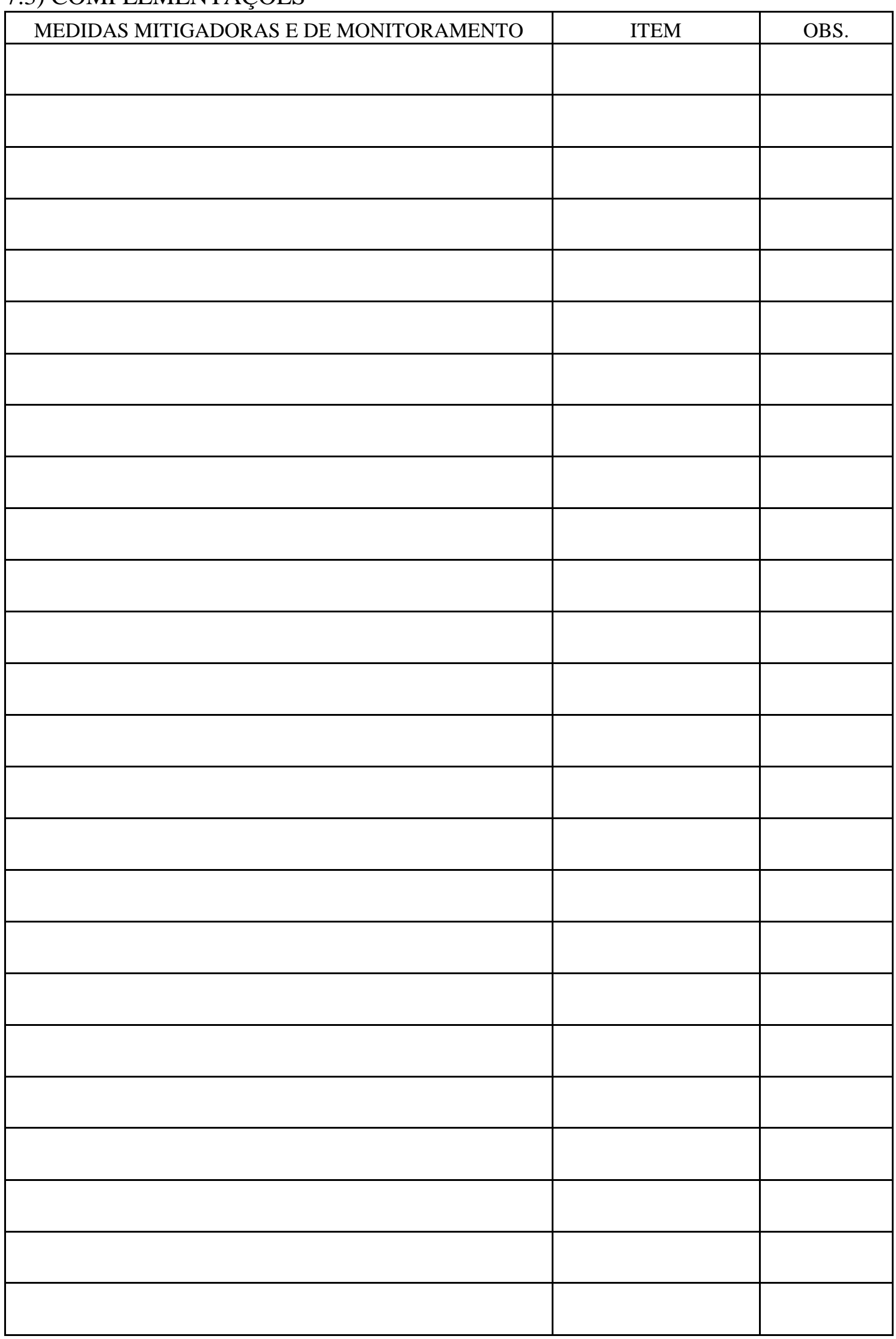


7.4) PARECER DAIA

\begin{tabular}{|c|c|c|}
\hline MEDIDAS MITIGADORAS E DE MONITORAMENTO & ITEM & OBS. \\
\hline & & \\
\hline & & \\
\hline & & \\
\hline & & \\
\hline & & \\
\hline & & \\
\hline & & \\
\hline & & \\
\hline & & \\
\hline & & \\
\hline & & \\
\hline & & \\
\hline & & \\
\hline & & \\
\hline & & \\
\hline & & \\
\hline & & \\
\hline & & \\
\hline & & \\
\hline & & \\
\hline & & \\
\hline & & \\
\hline & & \\
\hline & & \\
\hline
\end{tabular}


7.5) DELIBERAÇÃO CONSEMA (o empreendedor deve cumprir 3 exigências) MEDIDAS MITIGADORAS E DE MONITORAMENTO 
7.6) LICENÇA DE INSTALAÇÃO

\begin{tabular}{|l|l|}
\hline MEDIDAS MITIGADORAS E DE MONITORAMENTO & OBS. \\
\hline & \\
\hline & \\
\hline & \\
\hline & \\
\hline & \\
\hline & \\
\hline & \\
\hline & \\
\hline & \\
\hline
\end{tabular}


8) ATA DA REUNIÃO E DELIBERAÇÃO DO CONSEMA: conteúdo e apresentação, exigências adicionais.

9) PROCESSO(S) CETESB:- iniciativas anteriores ao protocolo do EIA/Rima, interações entre o processo Cetesb e o processo SMA, eventos posteriores à aprovação do Consema: emissão de LI, emissão de LF, fiscalização, ocorrências (autos de infração, notificações, advertências, multas), interação com DEPRN, DNPM, Prefeitura.

Forma de transcrição das medidas mitigadoras e de monitoramento no processo e nas licenças. Procedimentos e rotinas de fiscalização.

10) PROCESSO(S) DEPRN (iniciativas anteriores ao protocolo do EIA/Rima, interações entre os processos, eventos posteriores: autorização de desmatamento, fiscalização, ocorrências.

Forma de transcrição das medidas mitigadoras e de monitoramento no processo e nas licenças. 
$-248-$

11) MINA:

Evidências de implementação das medidas mitigadoras e de monitoramento Aderência entre o empreendimento e o projeto aprovado. 


\section{ANEXO D}

Documentação fotográfica. 



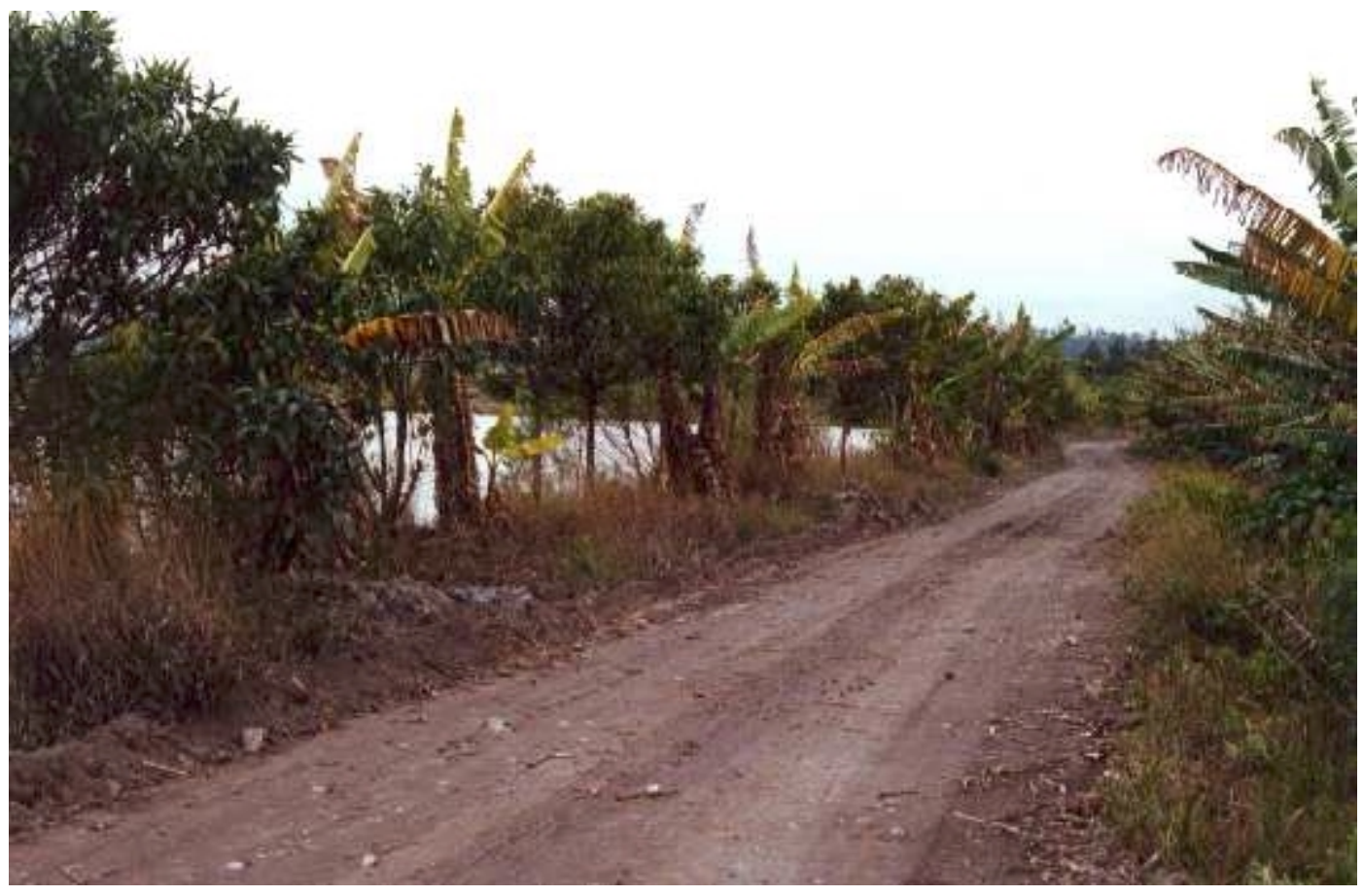

FOTO 1 - Aspectos de cortinas vegetais que circundam empreendimento.

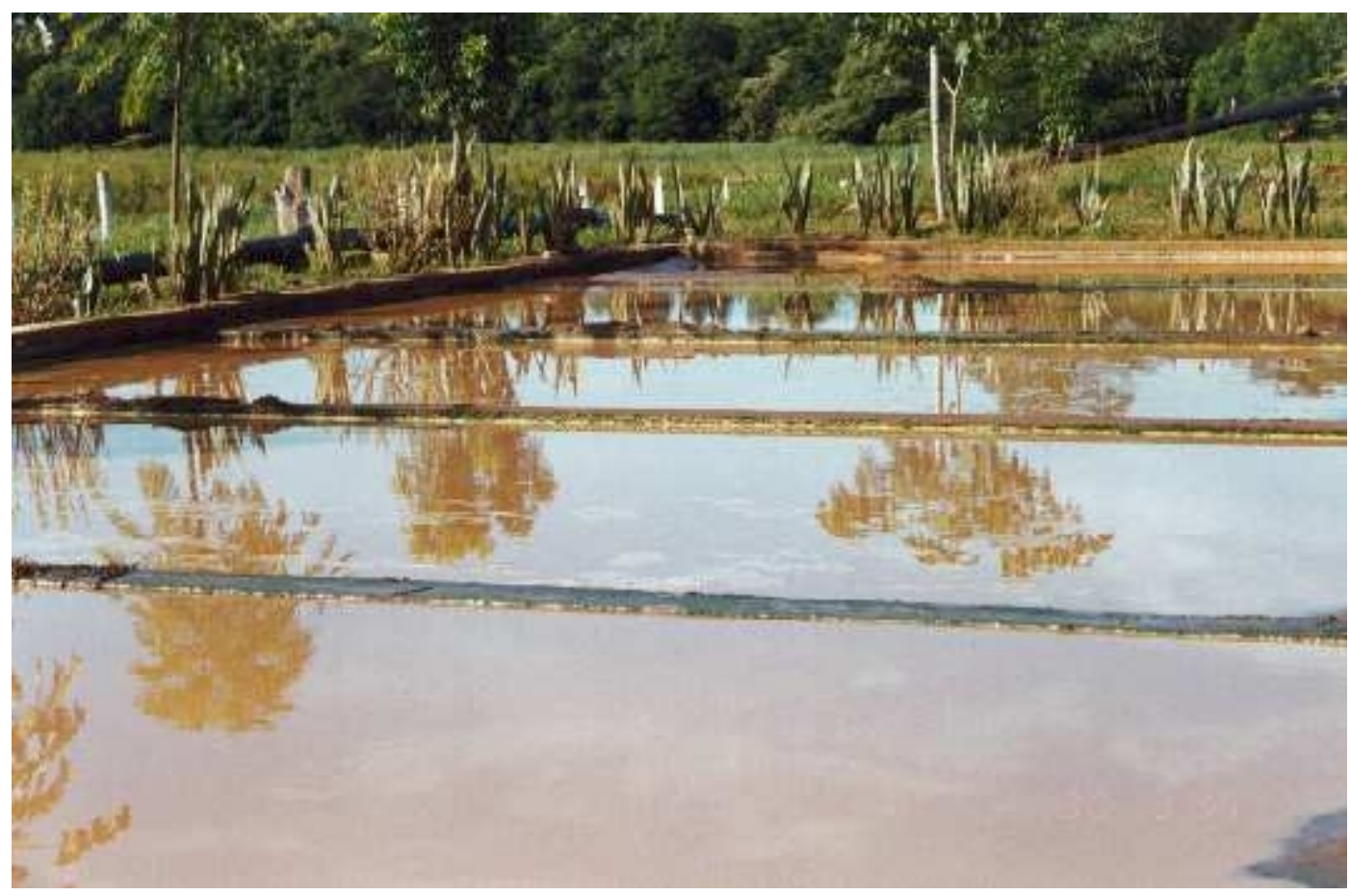

FOTO 2 - Caixa de decantação de finos, utilizada para clarificação de águas provenientes de pilhas de areia. 



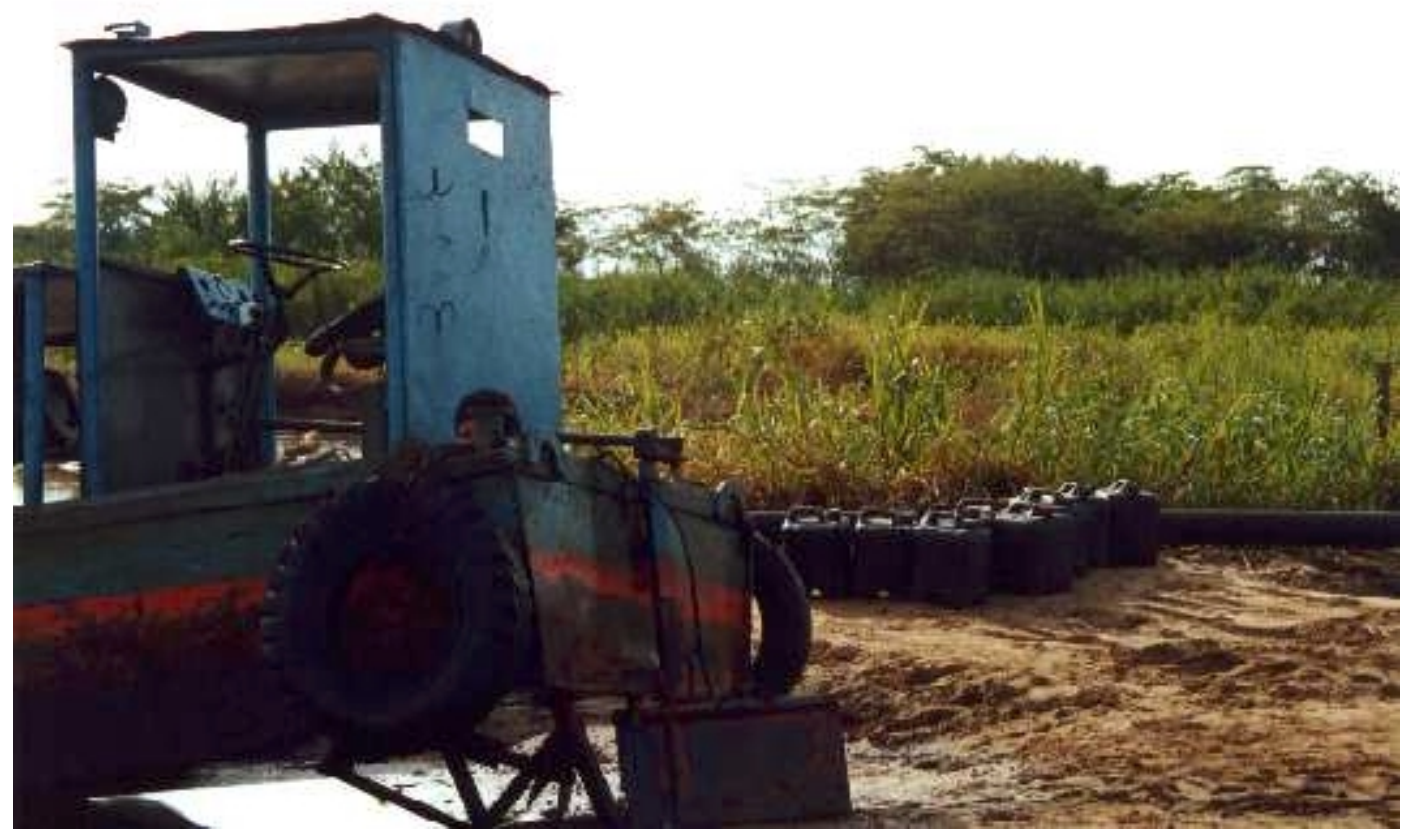

FOTO 3 - Armazenagem de combustíveis próximo de linha d'água, em área de inundação, além de equipamentos em manutenção.

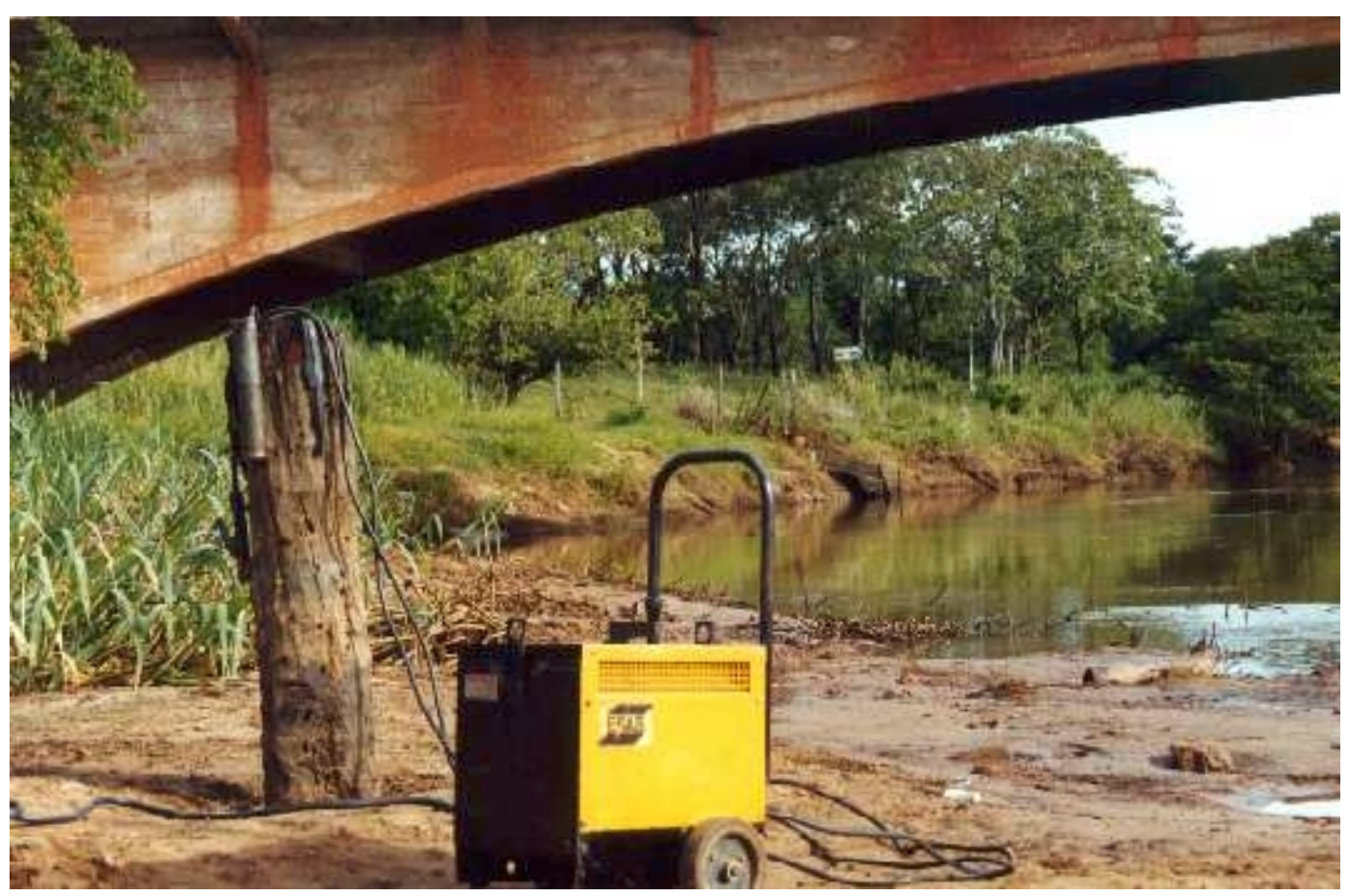

FOTO 4 - Área de operação de empreendimento próxima de linha d'água e de pilar de ponte. 



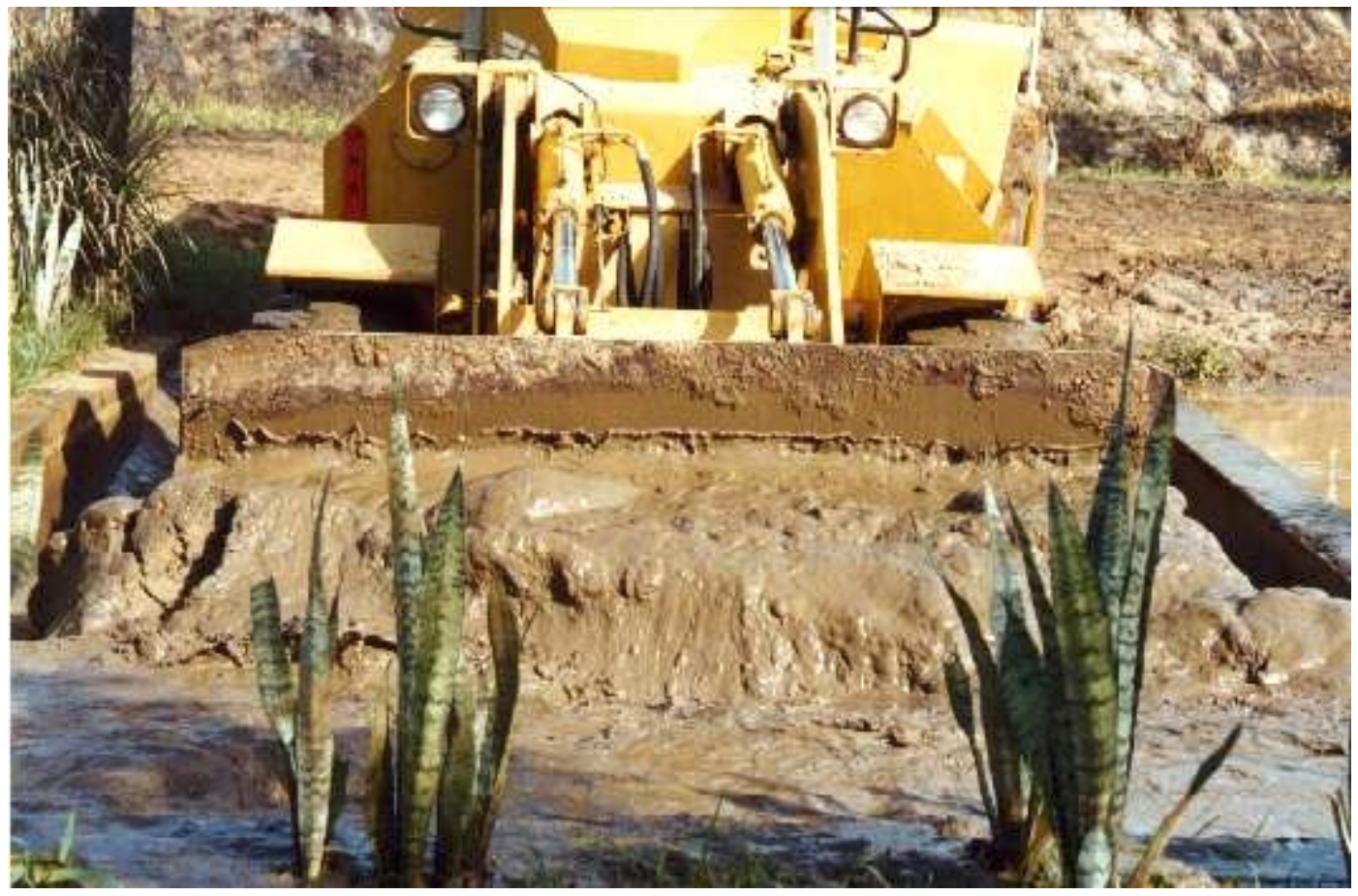

FOTO 5 - Material fino sedimentado é retirado de caixa de decantação e em seguida depositado em pilha próxima de linha d'água, em área de APP.

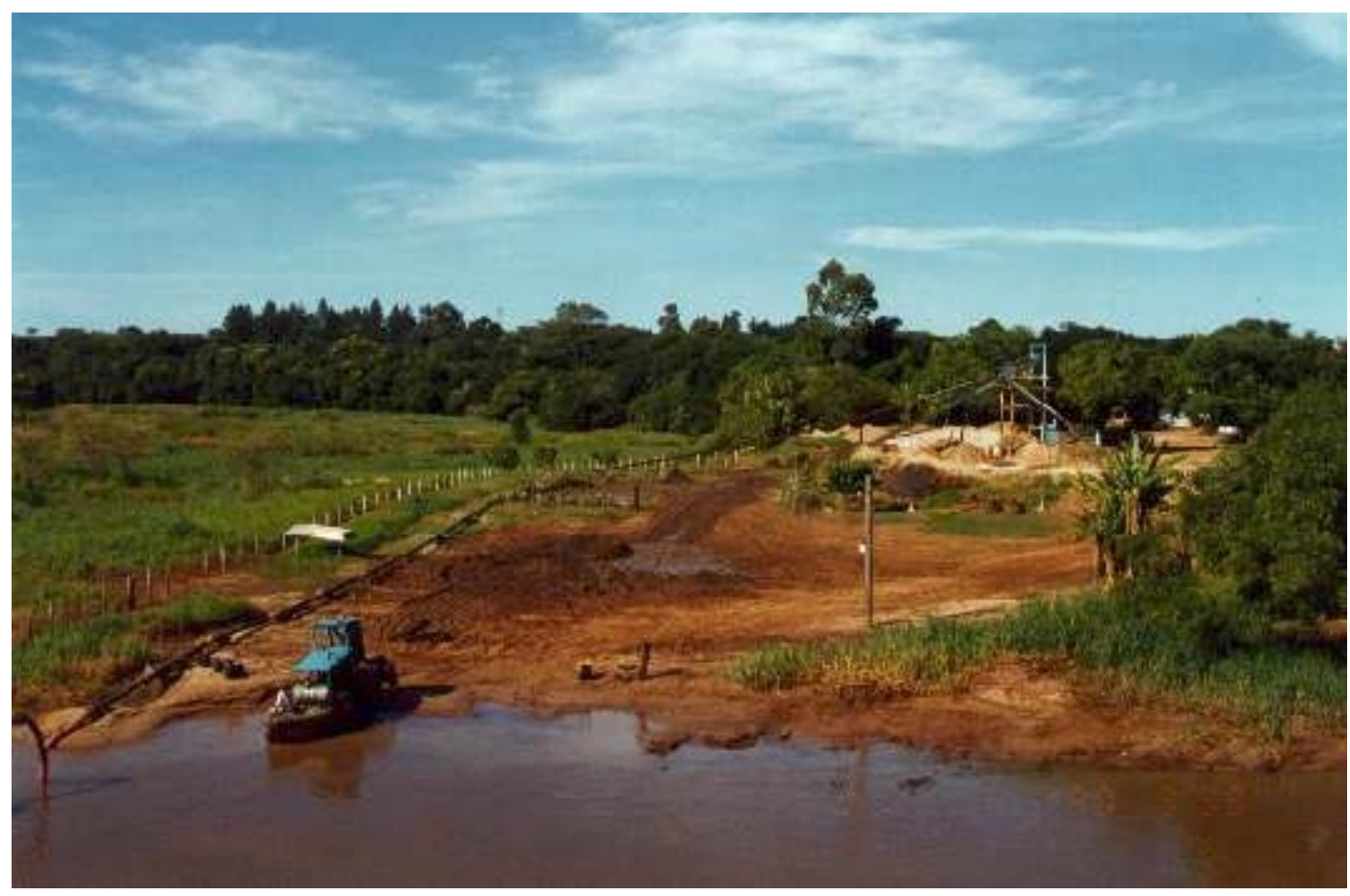

FOTO 6 - Vista geral de empreendimento. No centro da foto, destaca-se área utilizada para deposição temporária de material fino retomado de caixa de decantação. 



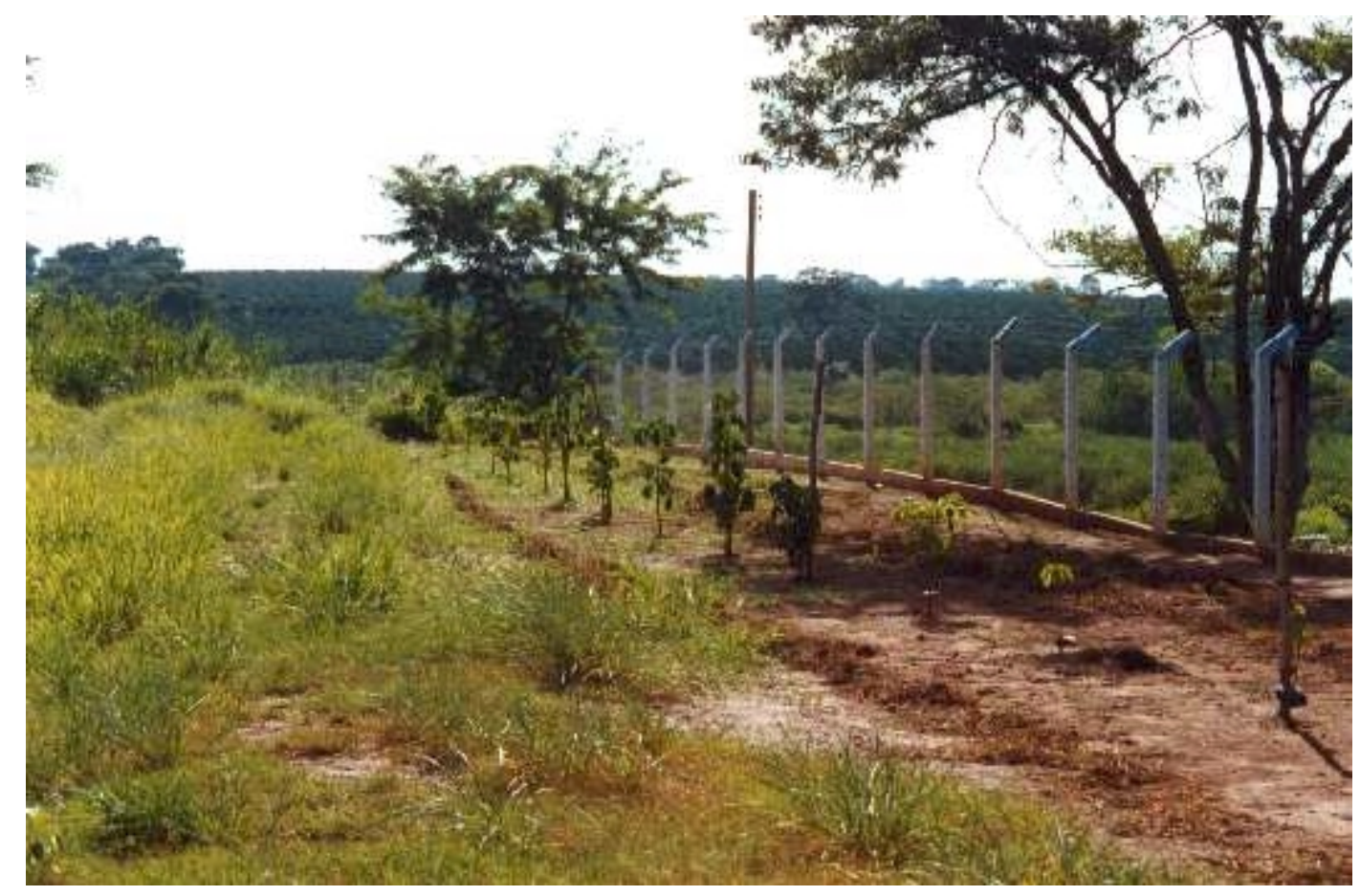

FOTO 7 - Barreira vegetal formada com essências nativas.

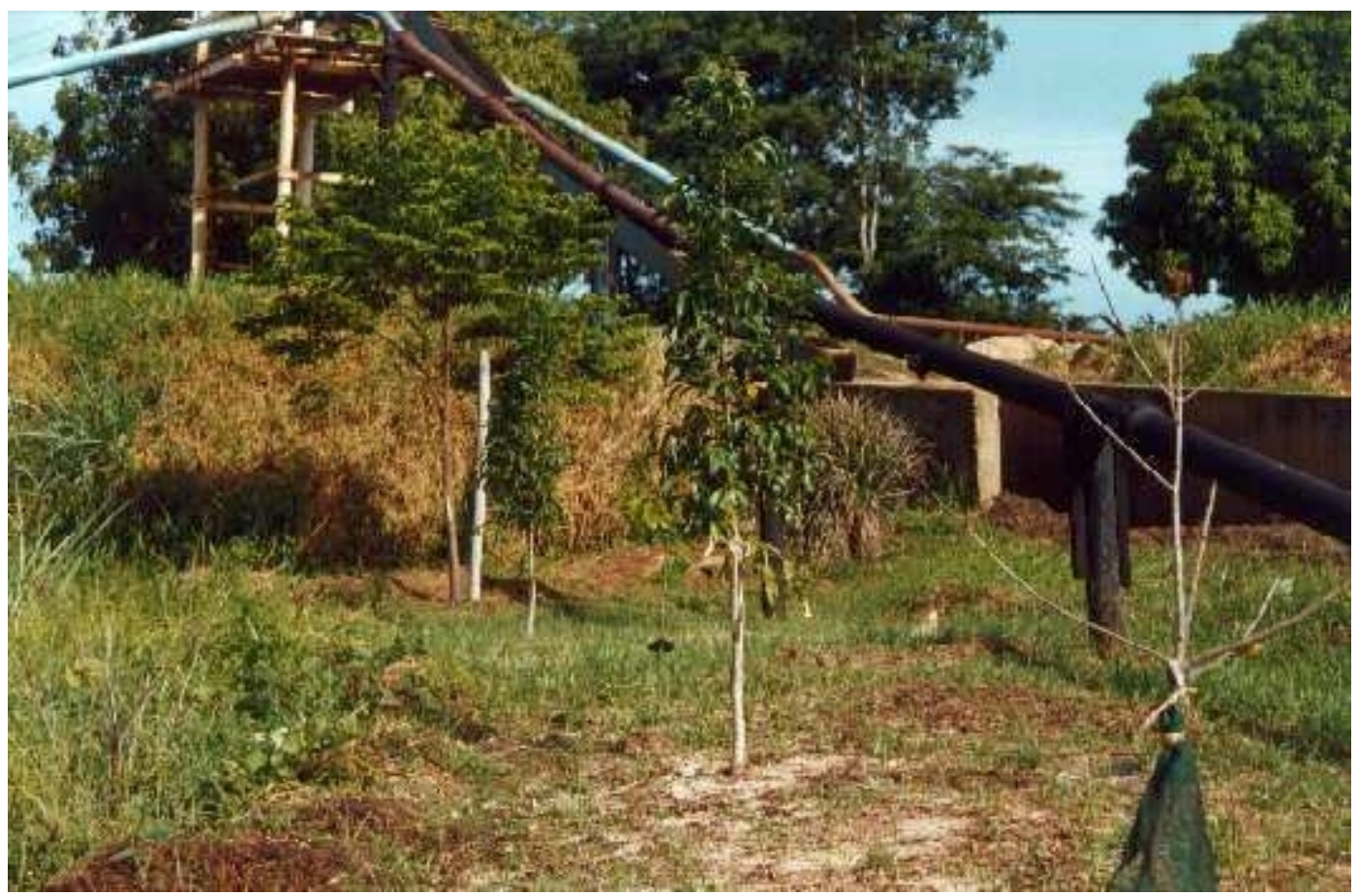

FOTO 8 - Essências nativas plantadas como medida de enriquecimento de vegetação ciliar. 



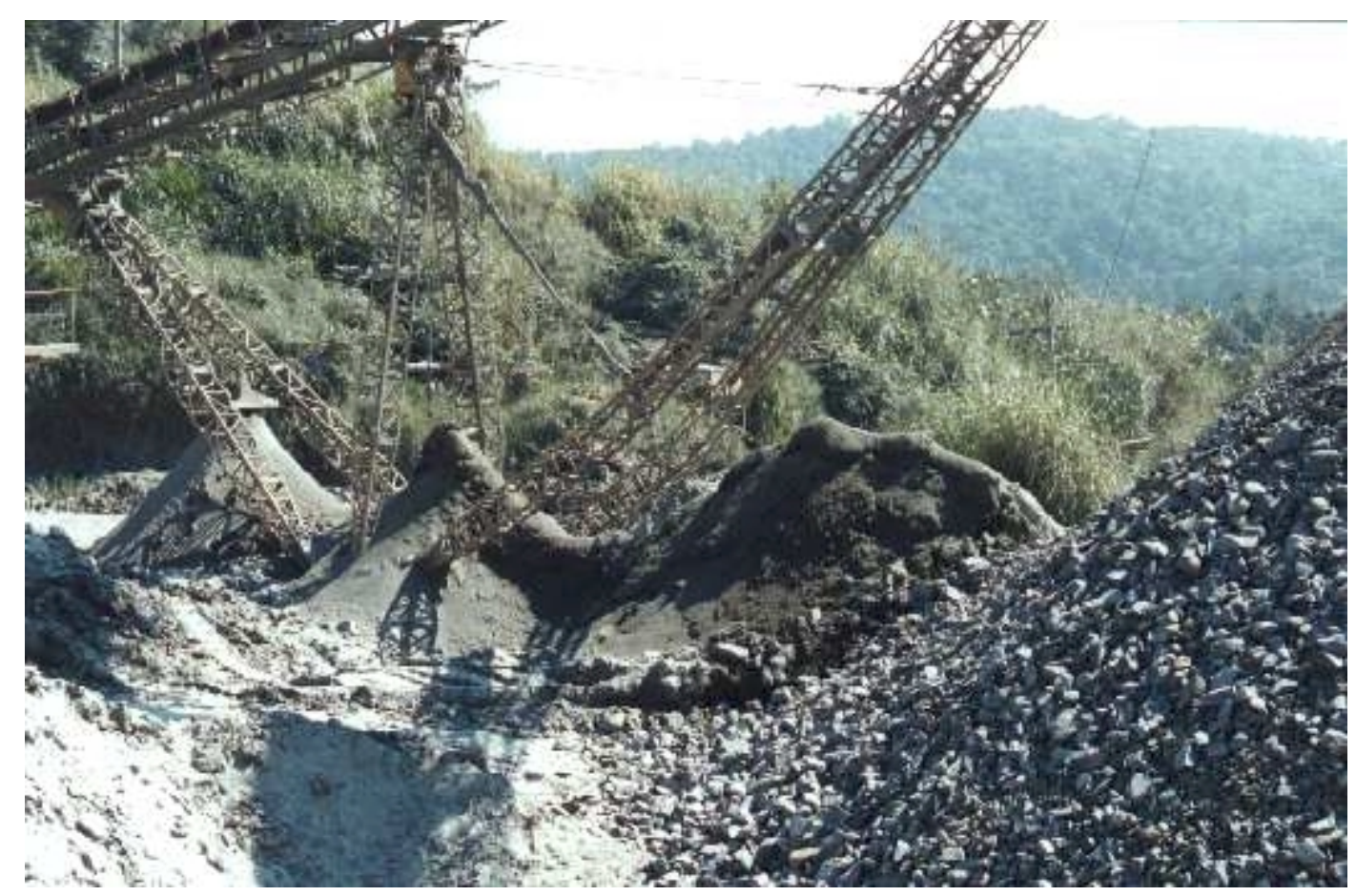

FOTO 9 - Acúmulo de material úmido depositado sob correia transportadora devido à ação de aspersão de água sobre poeira.

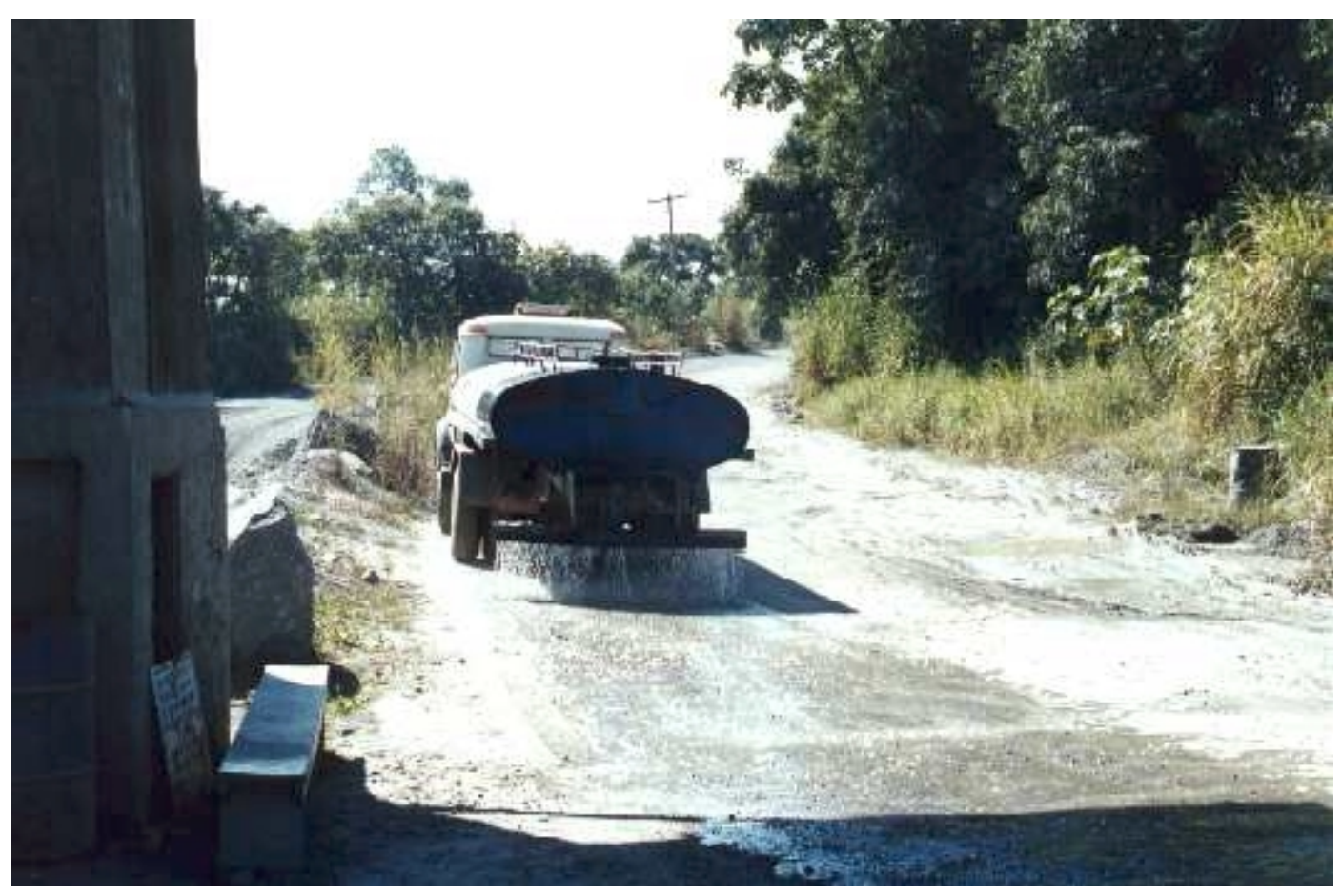

FOTO 10 - Caminhão-pipa em funcionamento. 



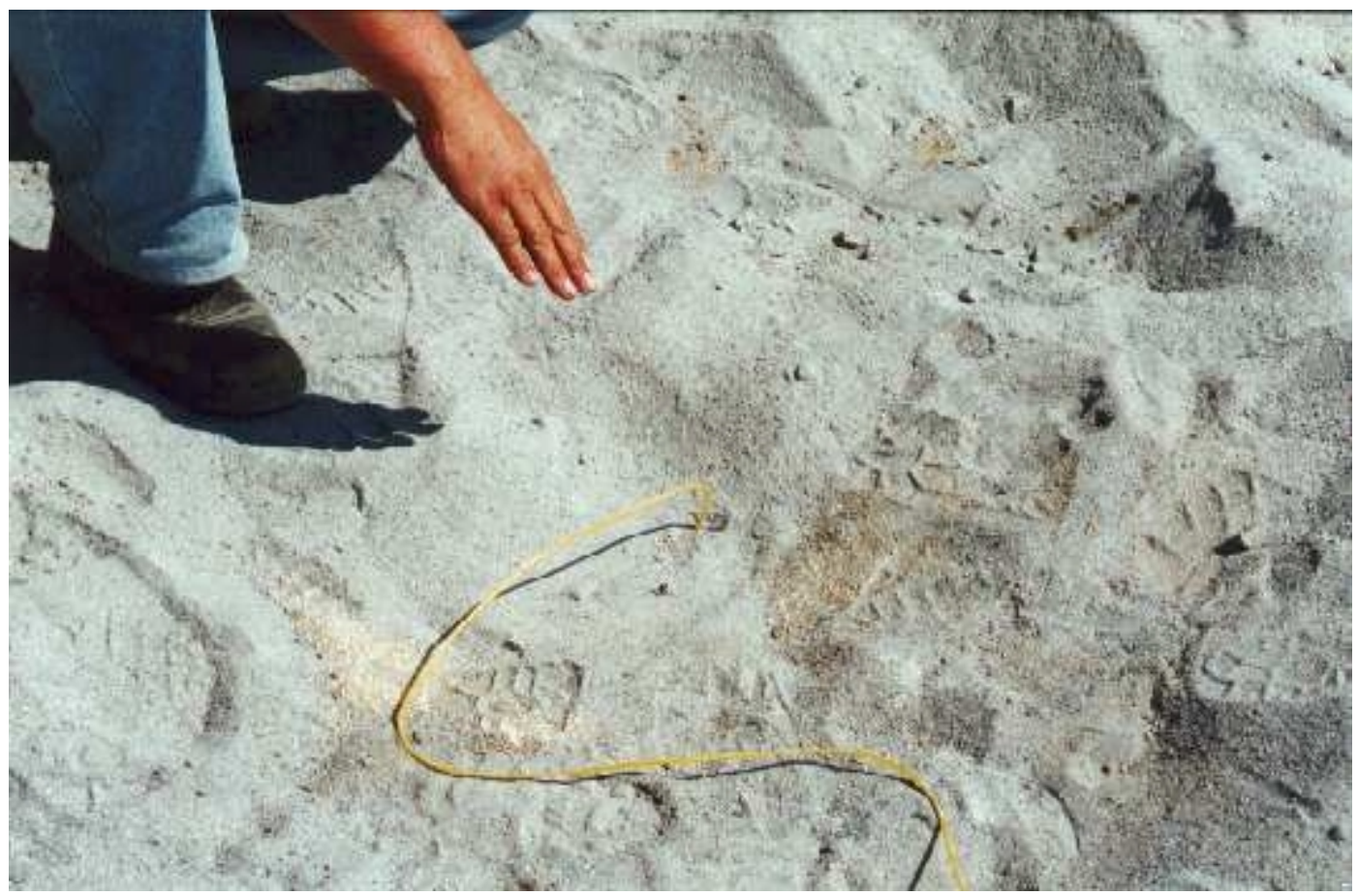

FOTO 11 - Detalhe de sistema de iniciação não-elétrica por tubo de choque ("espoleta Exel") e de furo tamponado com material fino.

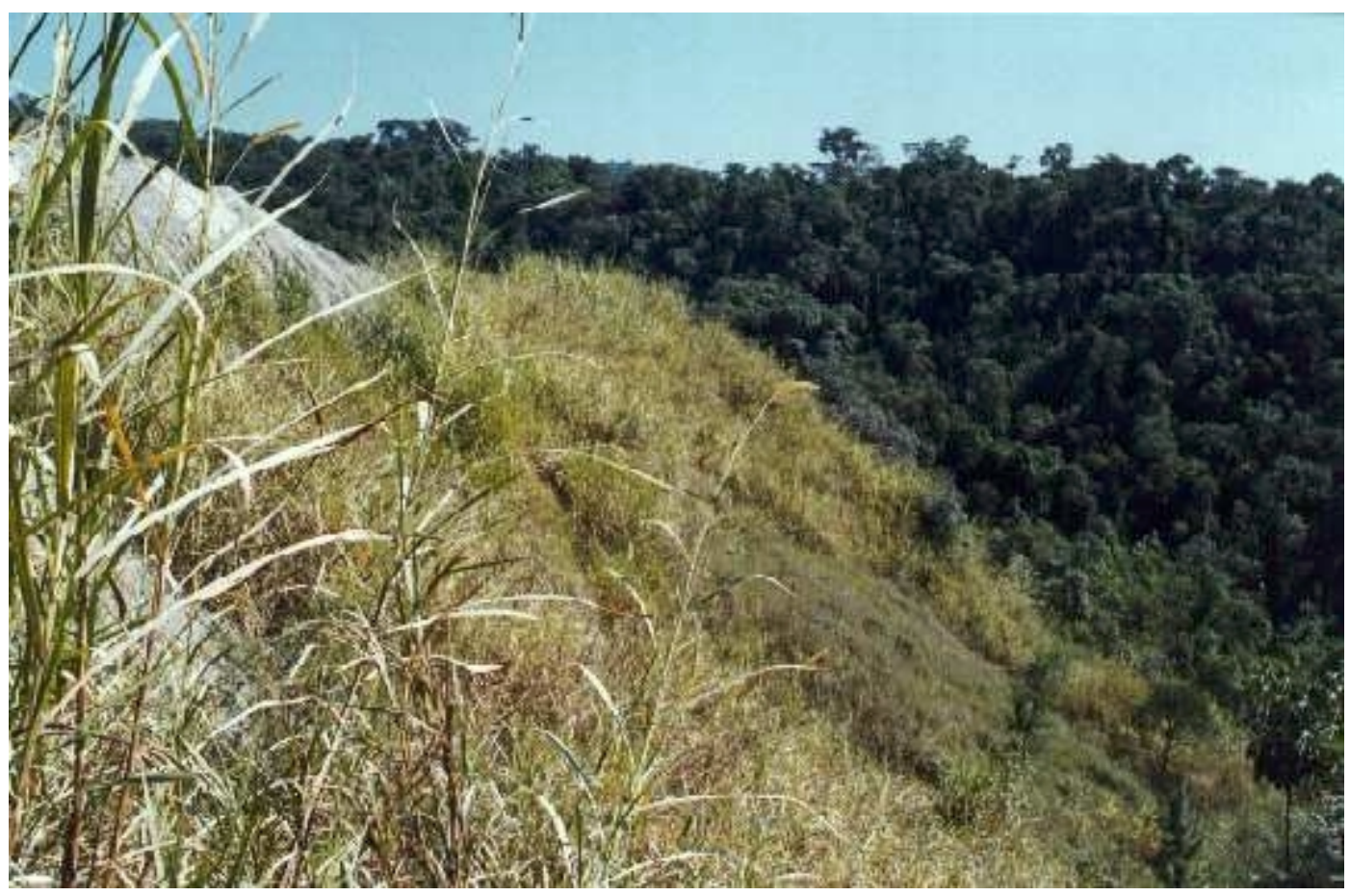

FOTO 12 - Vegetação rasteira de crescimento espontâneo, capim napier e algumas árvores plantadas para a proteção de talude sujeito à erosão e escorregamentos, próximo à drenagem e contígüo à mata nativa. 



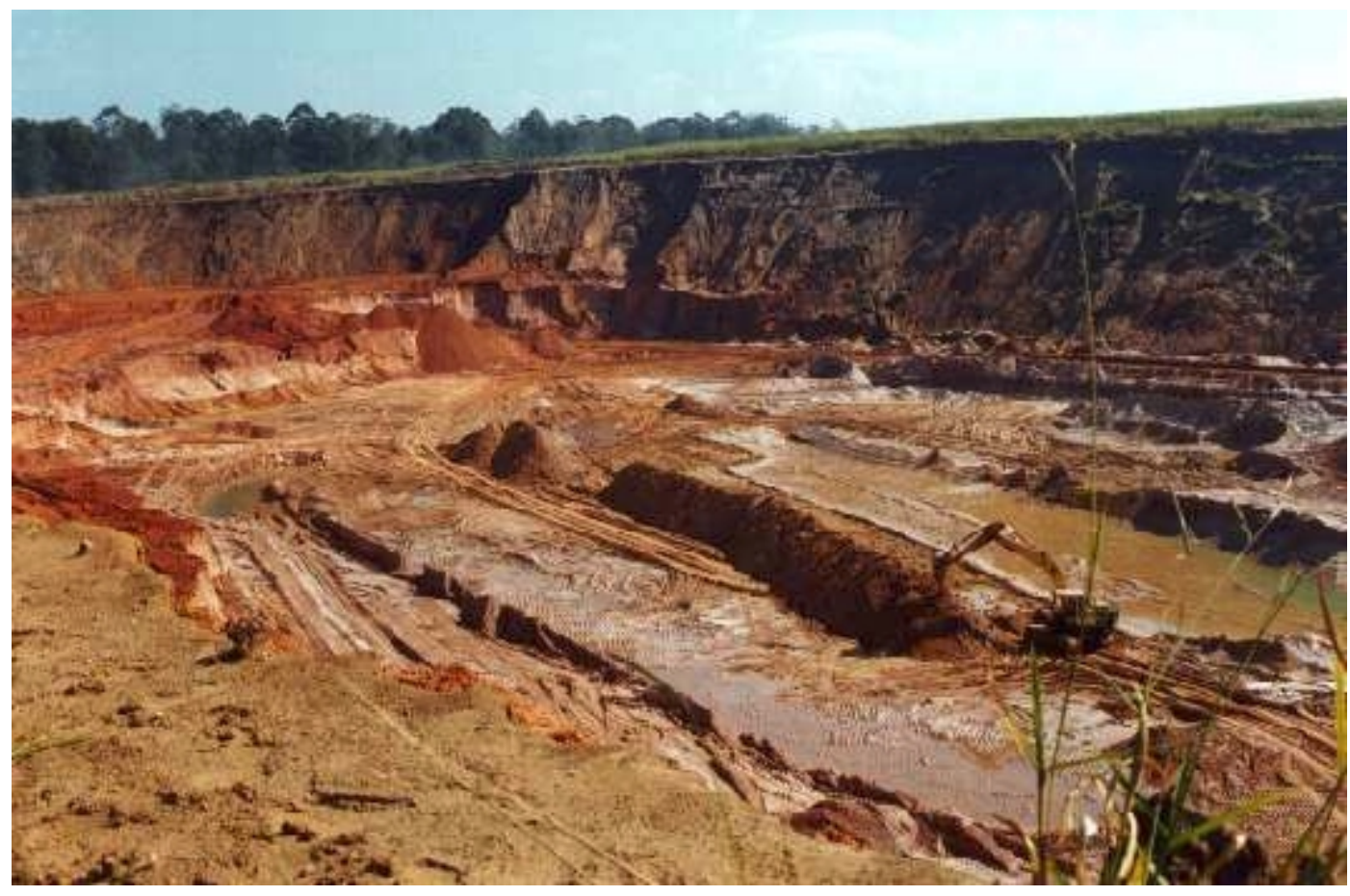

FOTO 13 - Panorâmica de frente de lavra onde se observa que o capeamento do depósito é pouco espesso e constituído de solo fértil.

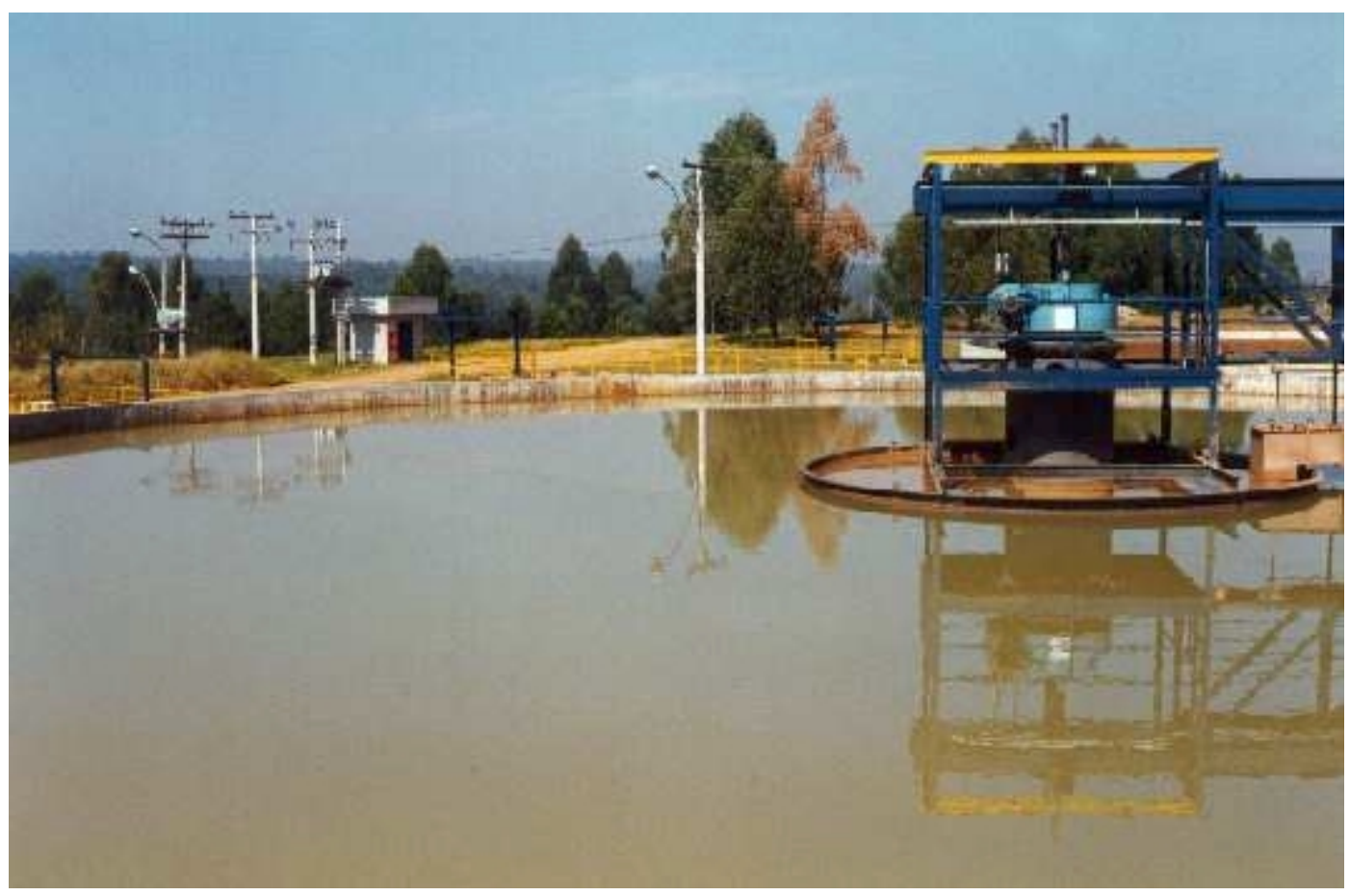

FOTO 14 - Espessador utilizado para clarificar efluentes de usina de beneficiamento, possibilitando redução do número de lagoas de sedimentação. 



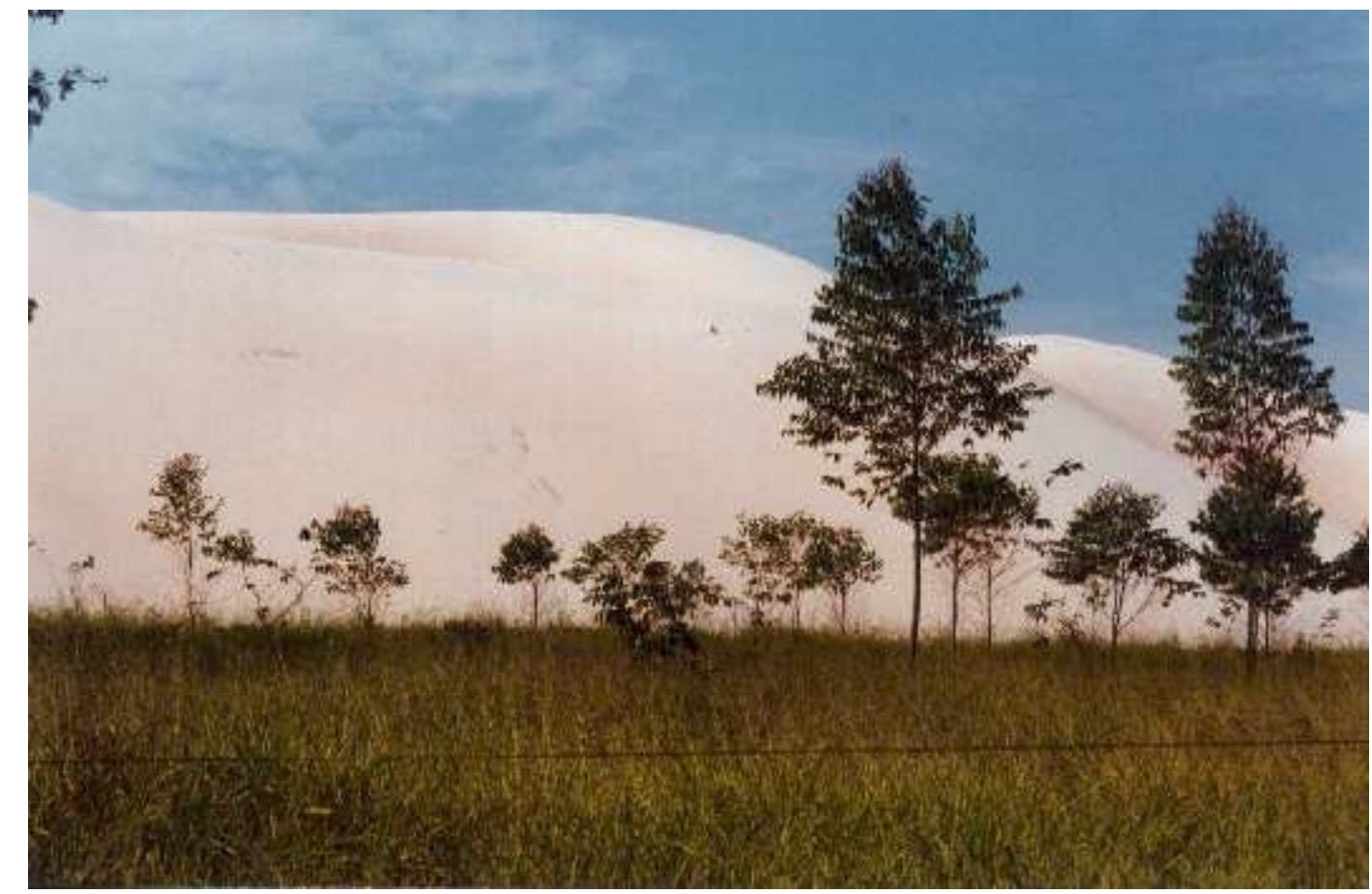

FOTO 15 - Vista pelo lado de fora, a "cerca-viva" deveria mitigar a ocorrência de poeiras fugitivas, ruído e degradação visual.

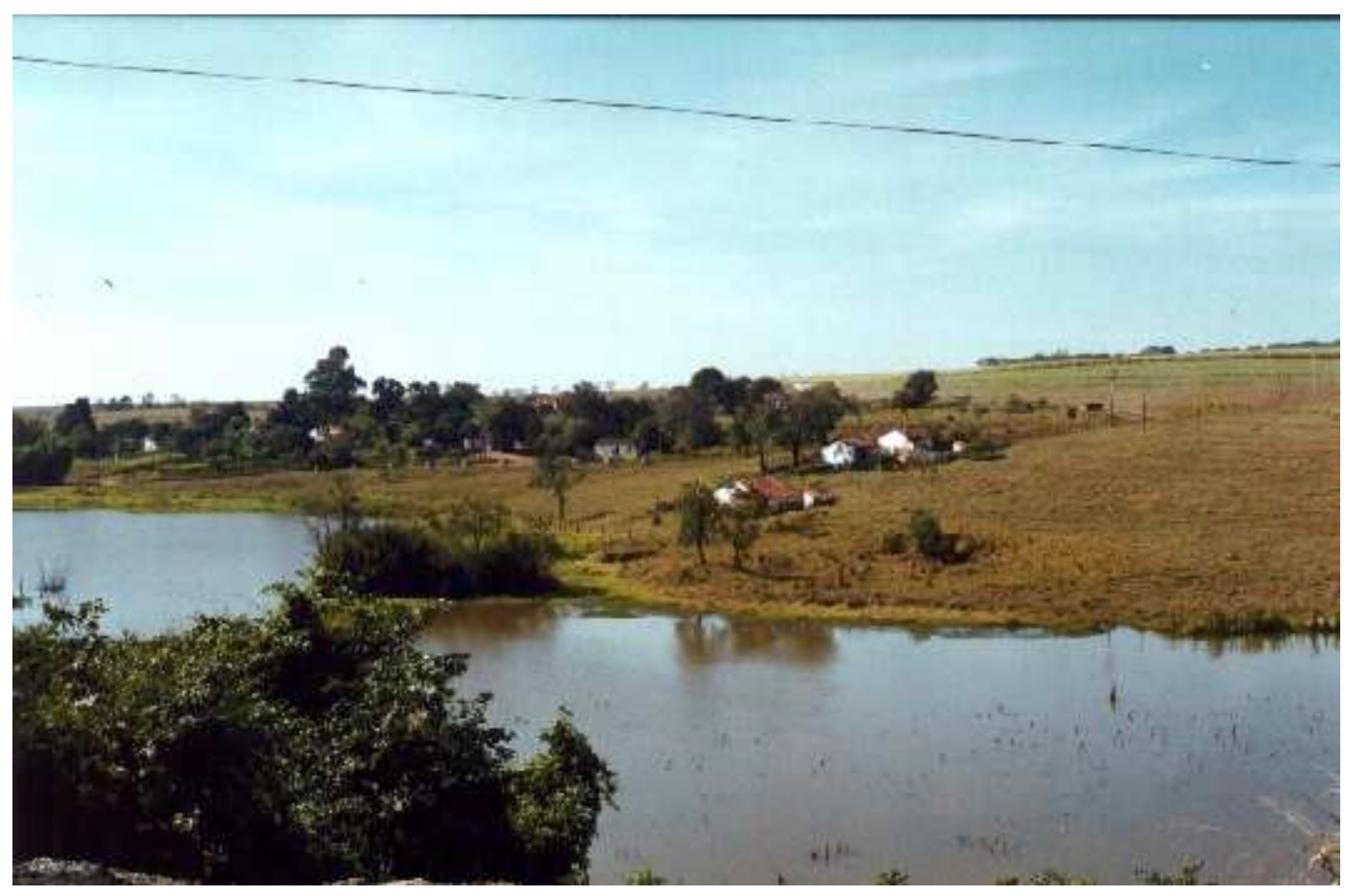

FOTO 16 - Vista, a partir de área de expedição de mina, de aglomerado de casas de propriedade de fazendeiro de quem área de empreendimento é arrendada. 



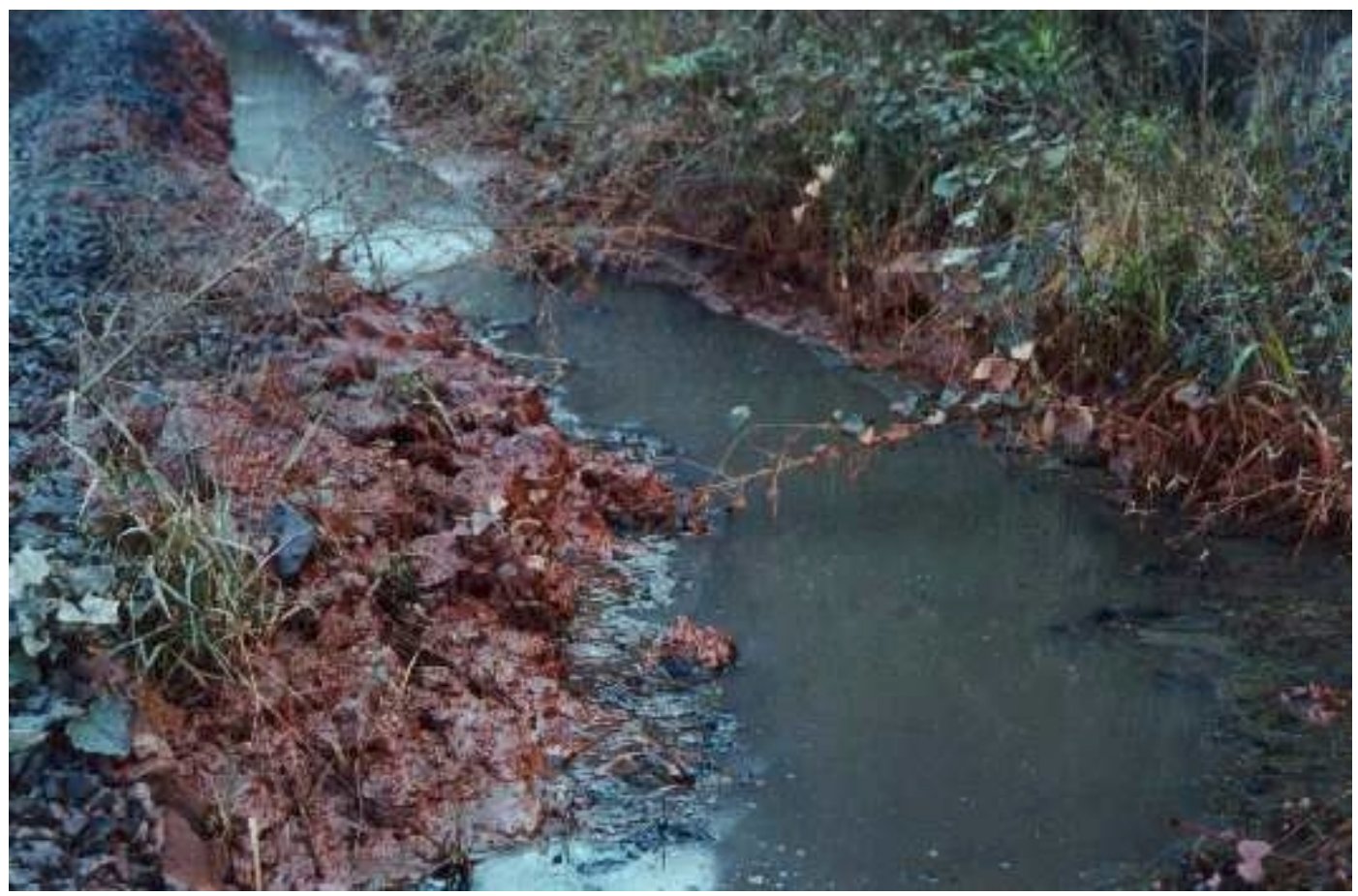

FOTO 17 - Água acumulada à beira de via interna em razão de obstrução de canaletas de drenagem por falta de limpeza.

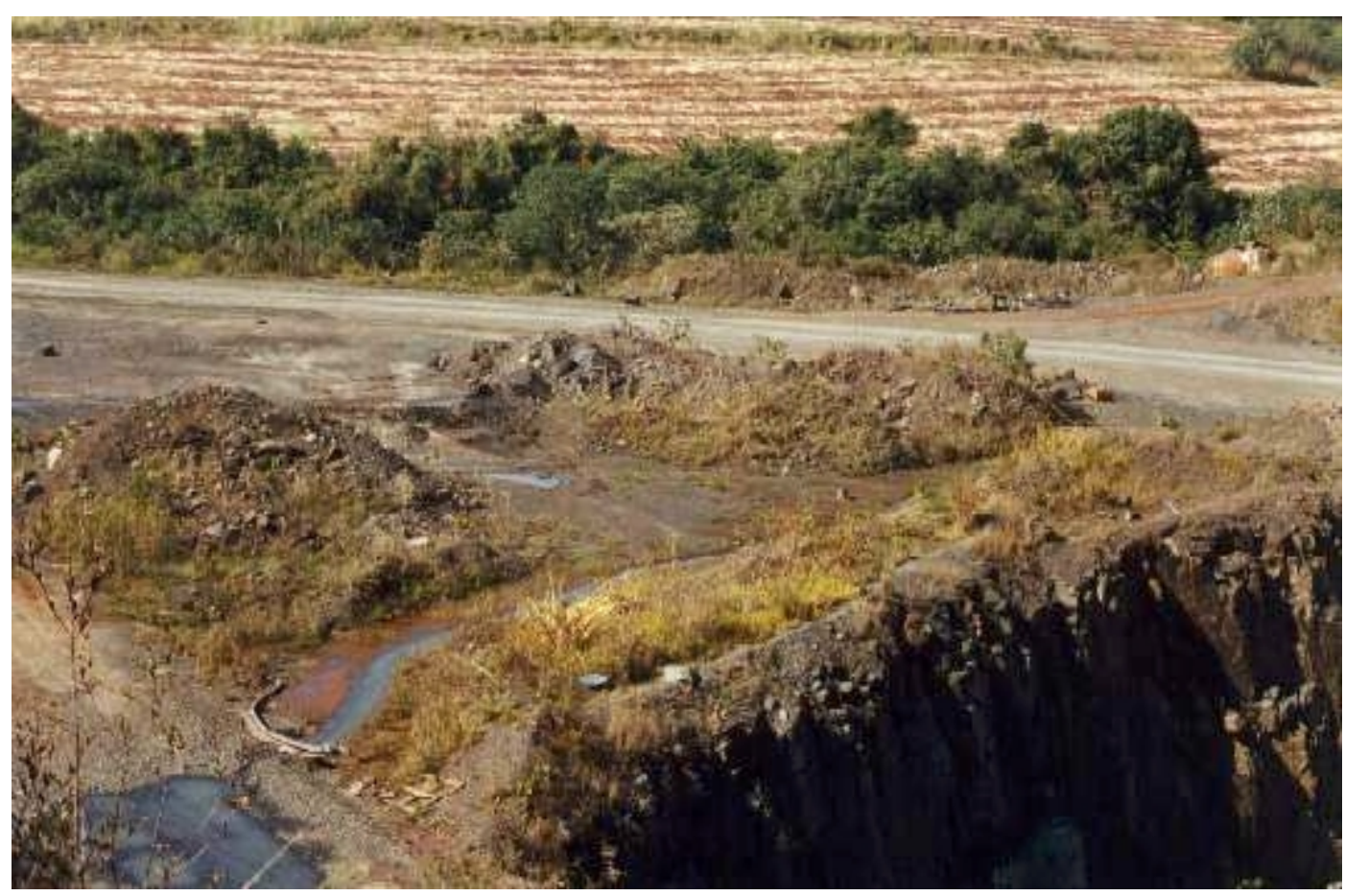

FOTO 18 - Bacia (lagoa) de drenagem para decantação de finos totalmente assoreada. 



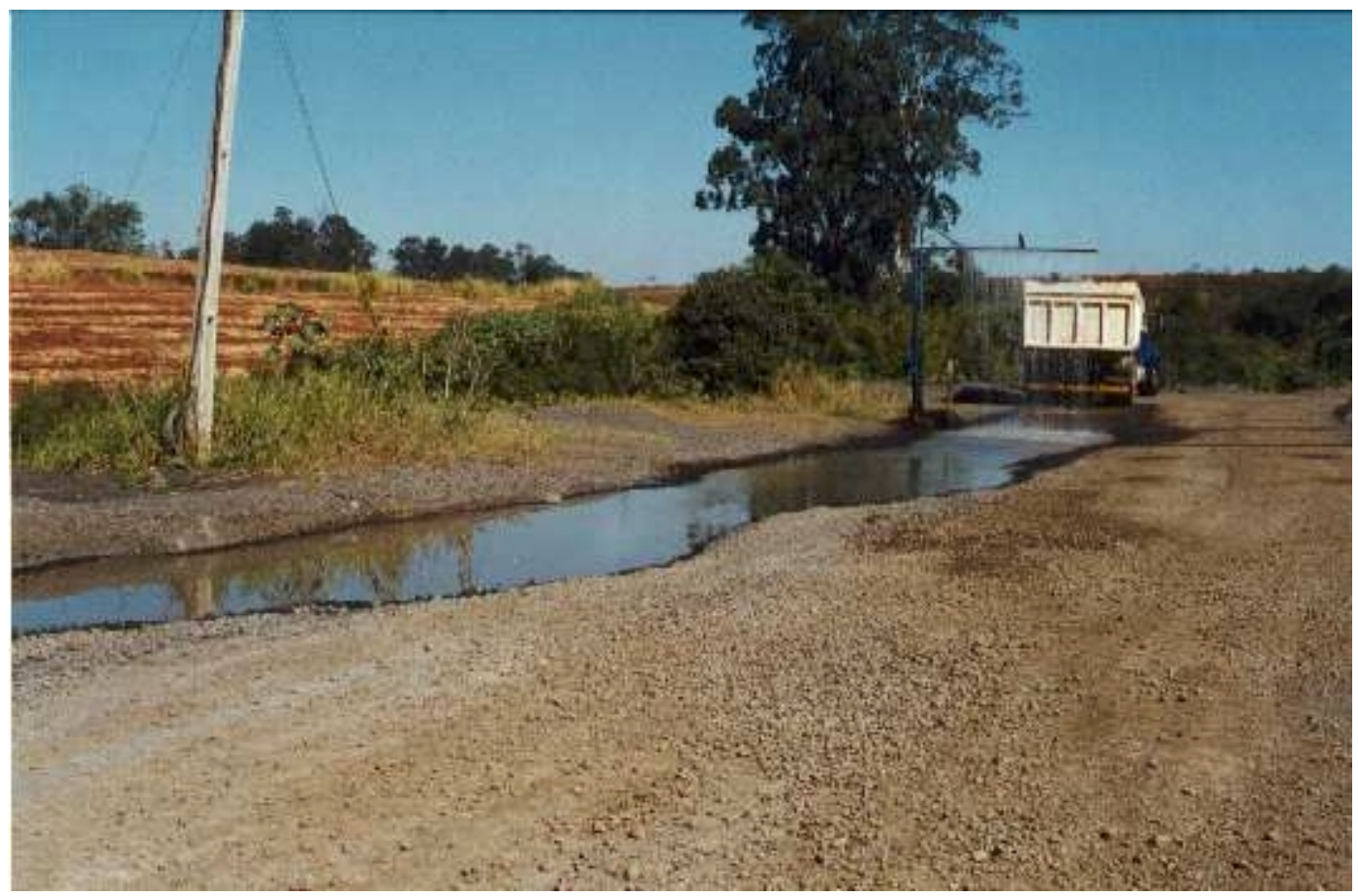

FOTO 19 - Chuveiro para lavagem de brita para expedição e água correndo em direção ao corpo d'água.

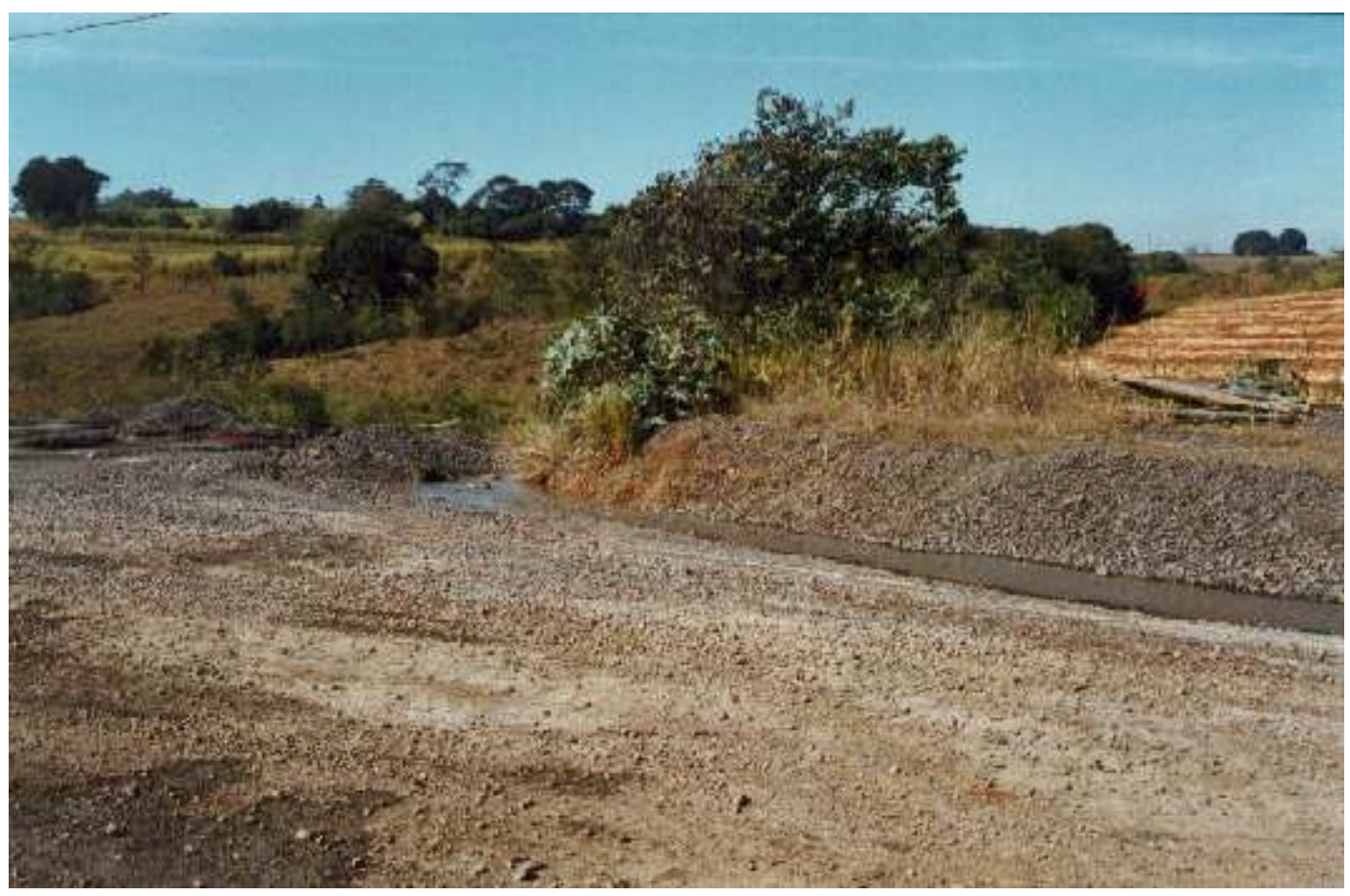

FOTO 20 - Água de lavagem de brita correndo em direção a corpo d'água. 



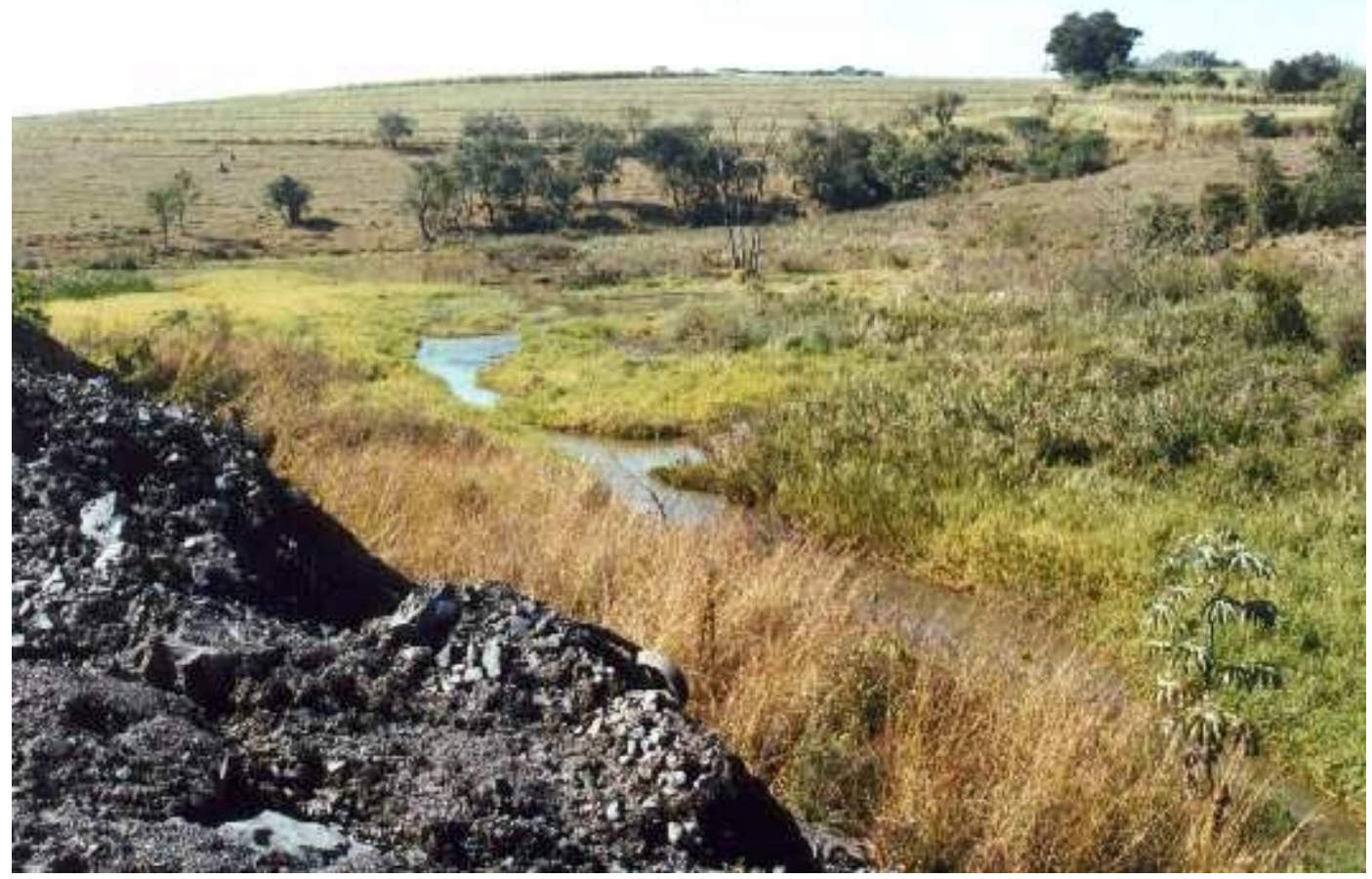

FOTO 21 - Córrego que margeia propriedade junto de área de britagem e recebe água de lavagem de brita e águas de drenagem superficial em geral.

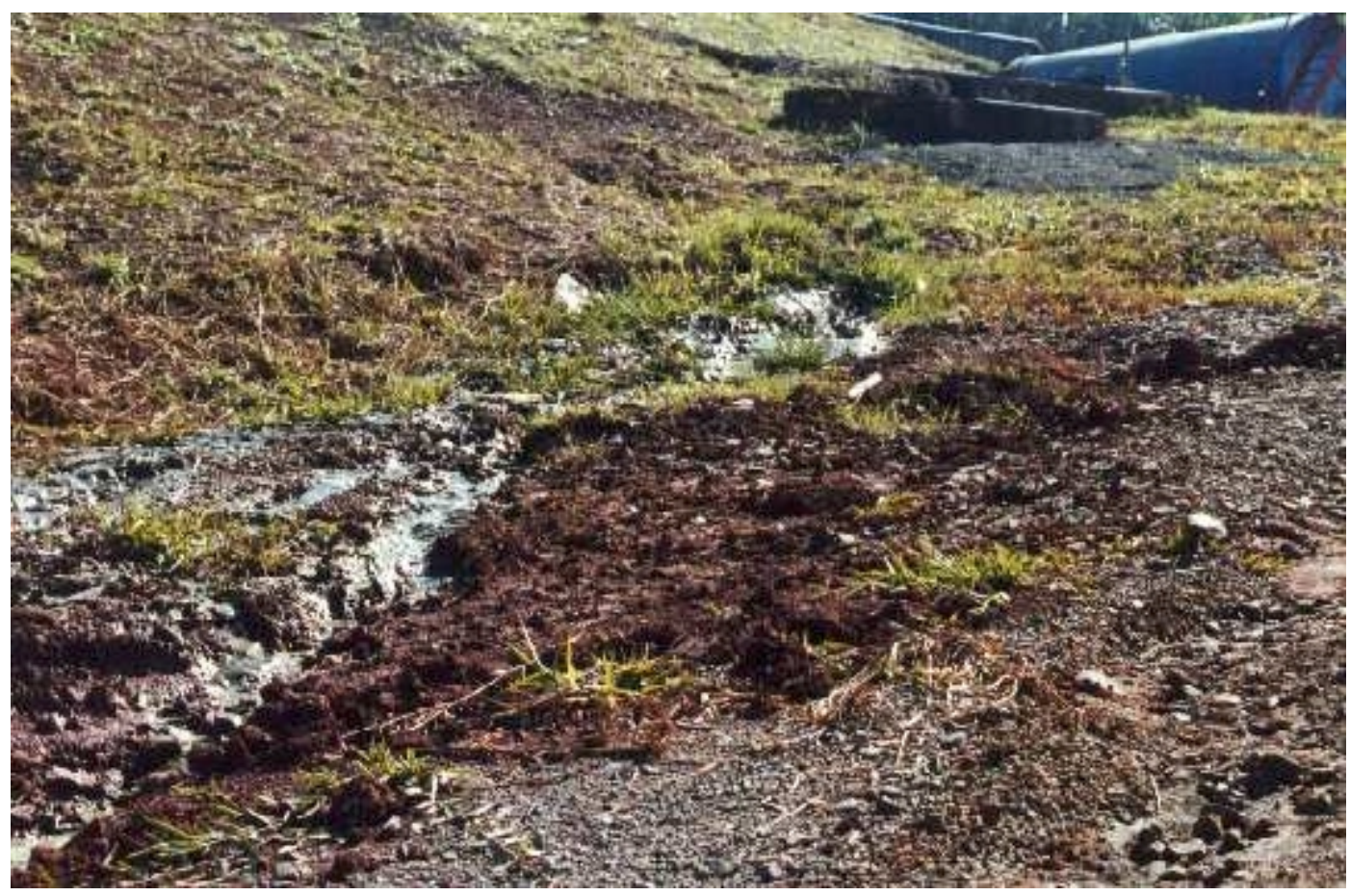

FOTO 22 - Transbordamento de caixa separadora de óleos e graxas instalada próximo de oficina e galpão para lavagem de máquinas e veículos. 



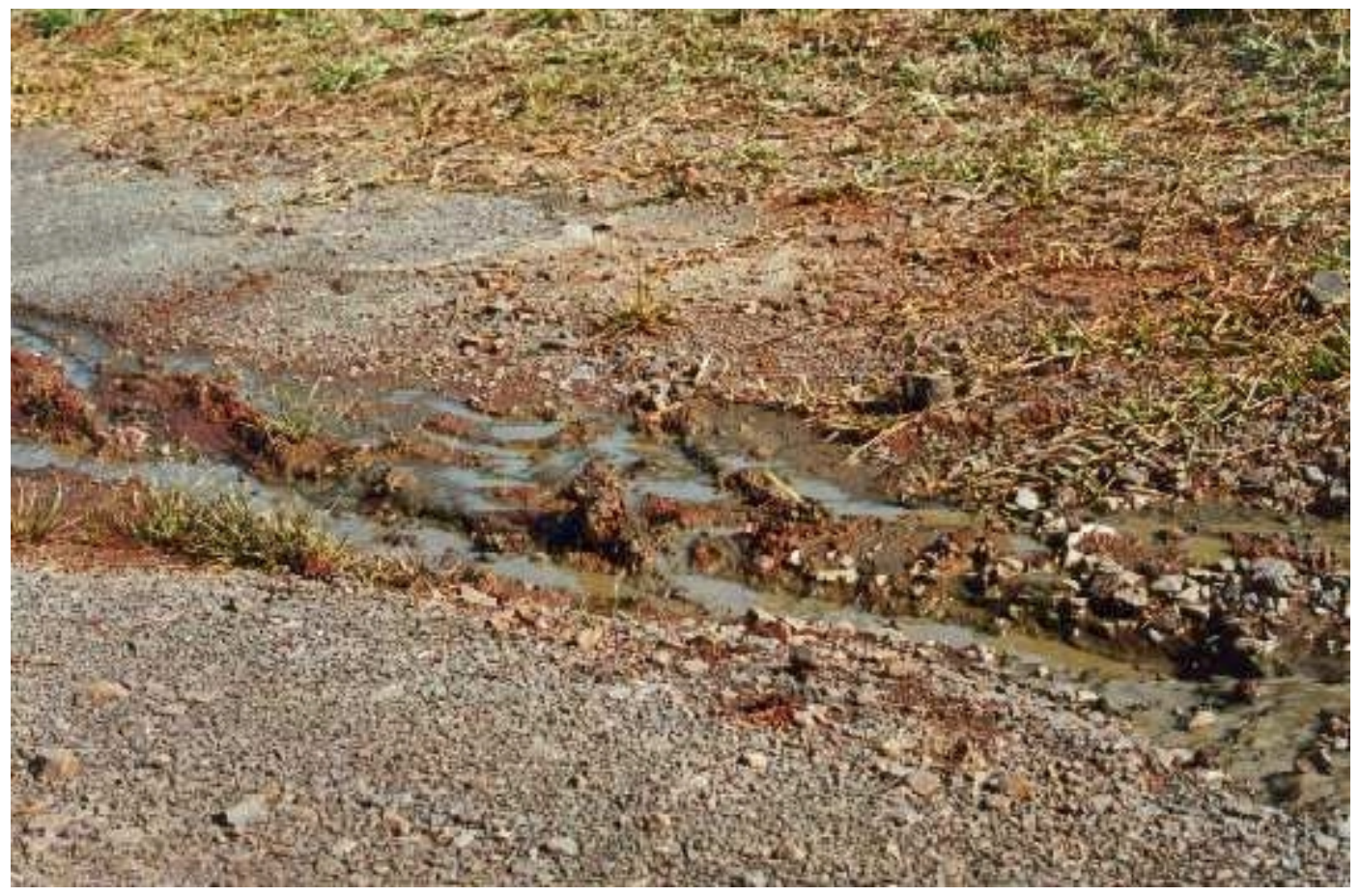

FOTO 23 - Água proveniente de transbordamento de caixa separadora de óleos e graxas anexa a oficina e galpão para lavagem de máquinas e veículos. 



\section{REFERÊNCIAS}

AGRICOLA, G. De re metallica. New York, Dover, 1950.

AGUDO, E.G. et al. Guia de coleta e preservação de amostras de água. São Paulo, CETESB, 1988.

ALMEIDA, A.S. et al. Controle e recuperação ambiental na mina de Cana Brava Goiás. São Paulo, IPT, 1992. (Boletim IPT, 66).

ALMEIDA, F.F.M.; CARNEIRO, C.D.R. Geleiras no Brasil: os parques glaciais de Salto e Itu. Ciência Hoje, v. 19, n. 112, p. 24-31, ago. 1995.

ALMEIDA, I. T. A poluição atmosférica por material particulado na mineração a céu aberto. São Paulo, 1999. 194 p. Dissertação (Mestrado) - Escola Politécnica, Universidade de São Paulo.

ANÔNIMO. A grande São Paulo e o papel do SPAM. Revista SPAM, n. 1, p. 4-12, abr. 1980.

ANÔNIMO. Fim do desmonte secundário. Minérios: Extração e Processamento, n. 215, p. 41, jan./fev. 1997a.

ANÔNIMO. Até no desmonte primário. Minérios: Extração e Processamento, n. 215, p. 43, jan./fev. 1997b.

ANUÁRIO MINERAL BRASILEIRO. [on line] Brasília, v. 26, 1997. Disponível através de http://www.dnpm.gov.br. [Arquivo capturado em 13 de abril de 2000]

ARTS, J. EIA follow-up: on the role of ex post evaluation in environmental impact assessment. Groningen, Geopress, 1998.

ARTS, J.; CALDWELL, P.; TACHÉ, M. EIA follow-up: good practice and future directions. In: ANNUAL MEETING OF THE INTERNATIONAL ASSOCIATION FOR IMPACT ASSESSMENT, 20, Hong Kong, 2000. /Selected papers/ Fargo, IAIA, 2000. n.p.

ASSOCIAÇÃO BRASILEIRA DE NORMAS TÉCNICAS. Resíduos sólidos - NBR 10.004. Rio de Janeiro, 1987a.

ASSOCIAÇÃO BRASILEIRA DE NORMAS TÉCNICAS. Avaliação do ruído em áreas habitadas visando o conforto da comunidade - NBR 10.151. Rio de Janeiro, 1987b.

ASSOCIAÇÃO BRASILEIRA DE NORMAS TÉCNICAS. Minerações em áreas urbanas com uso de explosivos - redução de riscos - NBR 9653. Rio de Janeiro, 1989.

ASTETE, M. W. Ruído e vibrações. Saúde Ocupacional, v. 7, n. 27, p. 12-26, jul/set. 1979.

AU, E.; SANVICENS, G. EIA follow up monitoring and management. [on line] In: EIA PROCESS STRENGTHENING WORKSHOP, Canberra, 1995. Report. 1996. 
p.1-17. Disponível através de http//www.erin.gov.au/net/eianet.html. [Arquivo capturado em 13 de dezembro de 1999]

AUSTIN, D. E. Community participation in EIA follow-up. In: ANNUAL MEETING OF THE INTERNATIONAL ASSOCIATION FOR IMPACT ASSESSMENT, 20, Hong Kong, 2000. /Selected papers/ Fargo, IAIA, 2000. n.p.

BEANLANDS, G. E. Scoping methods and baseline studies in EIA. In: WATHERN, P., org. Environmental impact assessment: theory and practice. London, Unwin Hyman, 1988. p. 33-46.

BEANLANDS, G. E. Environmental assessment requirements at the World Bank. In: SIMPÓSIO SOBRE AVALIAÇÃO DE IMPACTO AMBIENTAL: SITUAÇÃO ATUAL E PERSPECTIVAS, São Paulo, 1991. Avaliação de impacto ambiental; org. por L.E. Sánchez. São Paulo, EPUSP, 1993. p. 91-101.

BENJAMIN, A. H. V. Introdução ao direito ambiental brasileiro. In: CONGRESSO INTERNACIONAL DE DIREITO AMBIENTAL, 3., São Paulo, 1999. Anais. São Paulo, IMESP, 1999. p. 76-124.

BISSET, R.; TOMLINSON, P. Monitoring and auditing of impacts. In: WATHERN, P., org. Environmental impact assessment: theory and practice. London, Unwin Hyman, 1988. p. 117-28.

BLIGHT, G.E.; WILLIAMSON, J.R.G. Tailings dams and the environment in South Africa. International Water Power \& Dam Construction, p. 22-7, Oct. 1994.

BRANCO, S.M. Hidrobiologia aplicada à engenharia sanitária. 3.ed. São Paulo, CETESB/ ASCETESB, 1986.

BRASIL. Ministério do Meio Ambiente. Instituto Brasileiro do Meio Ambiente e dos Recursos Naturais Renováveis. Diretoria de Controle Ambiental:- Edital. [on line] Diário Oficial da União, Brasília, 6 ago. 1999. Disponível através de http://ww2.in.gov.br/netacgi/nph-brs"s1=D03+e+.../Diario Oficial. html\&SECT1=DOFI. [Arquivo capturado em 09/03/2000]

BUCKLEY, R. Cumulative environmental impacts. In: PORTER, A. L.; FITTIPALDI, J. J. eds. Environmental methods review: retooling impact assessment for the New Century. Fargo, AEPI, 1998. p. 95-9.

CABRAL JUNIOR., M.; ALMEIDA, E. B. Geologia e principais aplicações dos minerais industriais no Estado de São Paulo. In: ENCONTRO DE MINERADORES E CONSUMIDORES, 7., Rio Claro, 1999. Atas. Rio Claro, ABC, 1999. p. 13.

CALDARELLI, C. E.; CALDARELLI, S. B. Política ambiental e legislação relativa ao patrimônio cultural brasileiro. In: ENCONTRO NACIONAL DE ESTUDOS SOBRE O MEIO AMBIENTE, 3, Londrina, 1991. Anais. Londrina, Universidade Estadual de Londrina, 1991. v. 1, p. 295-301.

CANADA. Natural Resources. Sustainable development of minerals and metals. Ottawa, Natural Resources Canada, 1995.

CANADA. Canadian Environmental Assessment Agency. Cumulative effects assessment: practitioners guide. Quebec, 1997a. [Draft for discussion]

CANADA. Natural Resources. Sustainable development of minerals and metals. Ottawa, Natural Resources Canada, 1997b. (Monograph, n. 4) 
CANTER, L. W. Environmental impact assessment. New York, McGraw-Hill, 1996.

CANTER, L. W. Concepts and principles of cumulative effects assessment. In: WORKSHOP ON CUMULATIVE EFFECTS ASSESSMENT, São Paulo, 1997. Cumulative effects assessment. São Paulo, AEAS/ABES, 1997. Cap. 1, p. 1-1/1-18.

CHAPOT, P. Etude des vibrations provoquées par les explosifs dans les massifs rocheux. Paris, LCPC, 1981. (Rapport de Recherche, n. 105)

CLÁUDIO, C. B.; KONO, E. C. K. Evolução do quadro institucional ambiental no Estado de São Paulo nas últimas quatro décadas, com ênfase para AIA. Avaliação de Impactos, v. 1, n. 3, p. 93-105, 1997.

COMISSÃO MUNDIAL SOBRE MEIO AMBIENTE E DESENVOLVIMENTO. Nosso futuro comum. 2.ed. Rio de Janeiro, Editora da Fundação Getúlio Vargas, 1991.

CONNOR, D. M. Public participation: a manual. Victoria, B. C. Connor Development Services, 1998.

DERÍSIO, J. C. Introdução ao controle da poluição ambiental. São Paulo, CETESB, 1992.

DIAS, E.G.C.S. Levantamento e análise do mercado produtor mineral paulista. In: CONGRESSO BRASILEIRO DE GEOLOGIA, 31., Balneário de Camboriú, 1980. Anais. São Paulo, SBG, 1980. v. 3, p. 1664-73.

DIAS, E. G. C. S.; SÁNCHEZ, L. E. A participação pública versus os procedimentos burocráticos no processo de avaliação de impactos ambientais de uma pedreira. Revista de Administração Pública, v. 33, n. 4, p. 81-91, jul/ago. 1999.

DOWN, C. G.; STOCKS, J. Environmental impact of mining. London, Applied Science, 1977.

ENVIRONMENT CANADA Mine and mill wastewater treatment. Ottawa, Environment Canada, 1987. (Environmental Protection Series Reports, $\mathrm{EPS} 2 / \mathrm{MM} / 3)$.

ENVIRONMENTAL PROTECTION AGENCY. Standards support and environmental impact statement. Research Triangle Park, EPA, 1977. v. 1: Proposed standards of performance for lime manufacturing plants. (EPA-450/2-7007a).

ERICKSON, P. A A pratical guide to environmental impact assessment. San Diego, Academic Press, 1994.

ESTADOS UNIDOS. Council on Environmental Quality. Considering cumulative effects under the national environmental policy act. [on line] Washington, 1997. Disponível através de http://ceq.eh.doe.gov/nepa/ccenepa/ccenepa.htm. [Arquivo capturado em 13 de outubro de 1998]

ESTADOS UNIDOS. Council on Environmental Quality. CEQ - Regulations for implementing NEPA. [on line] Washington, 2001. Disponível através de http://ceq.eh.doe.gov/nepa/regs/ ceq/toc_ceq.htm. [Arquivo capturado em $19 \mathrm{de}$ janeiro de 2001]

ESTON, S. M. Impactos ambientais na mineração: gases e aerossóis. In: SÃO PAULO. Secretaria do Meio Ambiente. Companhia de Tecnologia de Saneamento 
Ambiental. Controle ambiental da mineração. São Paulo, Cetesb, 1994. v. 2, p. 142. (Série Didática Especial, n. 15)

ESTON, S. M. Uma análise dos níveis de vibração associados a detonações. São Paulo, 1998. 125 p. Tese (Livre Docência) - Escola Politécnica, Universidade de São Paulo.

EYSINK, G. et al. Metais pesados no vale do Ribeira e em Iguape - Cananéia. Ambiente, v. 2, n. 1, p. 6-13, 1988.

FARIA, A. A. C. A contestação do Relatório Ambiental Preliminar - RAP como instrumento de avaliação de impacto ambiental. In: SÃO PAULO. Secretaria do Meio Ambiente. Avaliação de impacto ambiental. São Paulo, SMA, 1998. v. 1, p. 31-4.

FERRER, J. T. V. Audiências públicas realizadas no processo de licenciamento e avaliação de impacto ambiental no Estado de São Paulo. Avaliação de Impactos, v. 4, n. 1, p. 79-100, 1998.

FINK, R.G. Recycling waste water. Pit \& Quarry, v. 88, p. 23-5, July 1995.

FUNDAÇÃO SOS MATA ATLÂNTICA/ INPE. [on line] São Paulo, 2000. Disponível através de http://www.sosmatatlantica.org.br/atlas/sp.htm. [Arquivo capturado em 9 de novembro de 2000]

FUNDAÇÃO SOS MATA ATLÂNTICA/ INPE/ ISA. Atlas da evolução dos remanescentes florestais e ecossistemas associados no domínio da Mata Atlântica no período 1990 - 1995. [on line] São Paulo, 1998. Disponível através de http://www.sosmatatlantica.org.br/relatorioatlasmataatlantica90-95.zip. [Arquivo capturado em 9 de novembro de 2000].

FURRIELA, R. B. Gestão ambiental e participação pública: análise das práticas no Conselho Estadual do Meio Ambiente de São Paulo. São Paulo, 1999 215p. Dissertação (Mestrado) - Programa de Mestrado em Ciência Ambiental, Universidade de São Paulo.

GEORGE, C. Environmental monitoring management and auditing. In: LEE, N.; GEORGE, C., eds. Environmental assessment in developing and transitional countries. New York, John Wiley, 2000. p. 177-93.

GOODLAND, R.; WEBB, M. The management of cultural property in World Bankassisted projects. Washington, World Bank, 1987. (World Bank Technical Paper, n. 62).

GOUVÊA, Y. M. G. A interpretação do Artigo $2^{\underline{o}}$ da Resolução Conama 1/86. In: SÃO PAULO. Secretaria do Meio Ambiente. Avaliação de impacto ambiental. São Paulo, SMA, 1998. v. 1, p. 11-23.

GOUVÊA, Y. M. G. Legislação ambiental. São Paulo, PECE, 1999. /Notas de aula da disciplina AI 017 - Legislação Ambiental/

GUIMARÃES, P. C. V.; MacDOWELL, S. F.; DEMAJOROVIC, J. Fiscalização do meio ambiente no Estado de São Paulo. Revista de Administração Pública, v. 31, n. 1, p. 96-111, jan/fev. 1997.

HERRMANN, H. Política de aproveitamento de areia no Estado de São Paulo: dos conflitos existentes às compatibilizações possíveis. Rio de Janeiro, CETEM/CNPq, 1992. 
HOLLICK, M. Enforcement of mitigation measures resulting from environmental impact assessment. Environmental Management, v. 5, n. 6, p. 507-13, 1981.

HOSSEIN, M. et al. A brief survey of current surface waste disposal practices in the metal mining industry. International Journal of Surface Mining and Reclamation, v. 7, p. 23-8, 1993.

INSTITUTO DE PESQUISAS TECNOLÓGICAS DO ESTADO DE SÃO PAULO S.A. Divisão de Minas e Geologia Aplicada. Recomendações técnicas para o desmonte de rochas em pedreiras. Brasil Mineral, n. 16, p. 27-31, mar. 1985.

INSTITUTO SOCIOAMBIENTAL. Povos indígenas. [on line] São Paulo, s.d.(a) Disponível através de http://www.socioambiental.org/website/povind/index.html. [Arquivo capturado em 11 de maio de 2000]

INSTITUTO SOCIOAMBIENTAL. Quilombos no Vale do Ribeira. [on line] São Paulo, s.d.(b) Disponível através de ttp://www.socioambiental.org/website/notícias/ quilombo/index.html. [Arquivo capturado em 11 de maio de 2000]

IRAMINA, W. S. Desmonte de rocha e controle ambiental. São Paulo, 1977. 128 p. Dissertação (Mestrado) - Escola Politécnica, Universidade de São Paulo.

KINSEY, J. S.; COWHERD JUNIOR., C. Fugitive emissions. In: BUONICORE, A. J.; DAVIS, W. T., eds. Air pollution engineering manual. New York, Van Nostrand, 1992. p. 133-46.

KONYA, C. J. Blast design. Ohio, Intercontinental Development, 1995.

KOVALICK, W.K. Reclaiming of degraded areas. In: SEMINÁRIO INTERNACIONAL DE GESTÃO E TECNOLOGIAS DE TRATAMENTO DE RESÍDUOS, 1. São Paulo, 1991. S.n.t. (Documento 2)

LAZZARINI, S. G. Estudos de caso: aplicabilidade e limitações do método para fins de pesquisa. Economia \& Empresa, v. 2, n. 4, p. 17-26, out./dez. 1995.

LEFEUVRE, M. La connaissance des écosystèmes aquatiques est un préalable à tout type d'exploitation et d'amenagement. In: UNION NATIONALE DES PRODUCTEURS DE GRANULATS. L'eau continentale et les carrières. Paris, Maison de la Chimie, 1986. p. 15-39.

LEGISLAÇÃO DE MEIO AMBIENTE LTDA. Legislação ambiental: Estado de São Paulo. São Paulo, LEMA, 1999a.

LEGISLAÇÃO DE MEIO AMBIENTE LTDA. Legislação ambiental federal. São Paulo, LEMA, 1999b.

MACHADO, P. A. L. Direito ambiental brasileiro. 7.ed. São Paulo, Malheiros, 1998.

McCALLUM, D. R. Environmental follow-up to federal projects: a national review. In: CONFERENCE ON FOLLOW-UP/AUDIT OF EIA RESULTS, Banff, 1985.

Proceedings: Audit and evaluation in environmental assessment and management: canadian and international experience. Otawa, Environment Canada, 1987. v. 2, p. 731-49.

McCOLD, L. N.; SAULSBURY, J. W. Including past and present impacts in cumulative impact assessments. Environmental Management, v. 20, n. 5, p. 767-76, 1996. 
McPHEAT, I.W. et al. The fine tailings problems in construction sand preparation. Quarry Management and Products, v. 4, n. 6, p. 159-63, June 1977.

MELLO, I. S. C. et al. Pólos produtores de bens minerais de uso na construção civil no Estado de São Paulo. In: SIMPÓSIO DE GEOLOGIA DO SUDESTE, 5., Penedo, 1997. Atas. Penedo, SBG, 1997. p. 445-6.

MILARÉ, E.; BENJAMIN, A. H. V. Estudo prévio de impacto ambiental: teoria, prática e legislação. São Paulo, Editora Revista dos Tribunais, 1993.

MILLER, S.; EMERICK, J. C. The secondary effects of mineral development. In: VOGELY, W. A. Economics of the mineral industries. 4.ed. New York, AIME, 1985. p. 625-39.

MONOSOWSKI, E. Políticas ambientais e desenvolvimento no Brasil. Cadernos Fundap, v. 9, n. 16, p. 15-24, jun. 1989.

MOREIRA, I.V.D. Vocabulário básico de meio ambiente. 4.ed. Rio de Janeiro, Fundação Estadual de Engenharia do Meio Ambiente, 1992.

ORTOLANO, L.; SHEPHERD, A. Environmental impact assessment: challenges and opportunities. Impact Assessment, v. 13, p. 3-30, 1995.

ORTOLANO, L. Environmental regulation and impact assessment. New York, John Wiley, 1997.

PARENTEAU, R. Public participation in environmental decision-making. Montreal, Federal Environmental Assessment and Review Office, 1988.

PARTIDÁRIO, M. R. Perspectivas futuras: emergência da avaliação ambiental estratégica. In: SÃO PAULO. Secretaria do Meio Ambiente. Avaliação de impacto ambiental. São Paulo, SMA, 1998. v.1, p.69-83.

RONZA, C. A política de meio ambiente e as contradições do estado: a avaliação de impacto ambiental em São Paulo. Campinas, 1998 108p. Dissertação (Mestrado) Instituto de Geociências, Universidade Estadual de Campinas.

RUIZ, M. S.; ATEM, S. M. Caracterização do mercado produtor mineral paulista. In: RUIZ, M. S.; NEVES, M. R., coords. Mercado produtor mineral no Estado de São Paulo: levantamento e análise. São Paulo, IPT/PRÓ-MINÉRIO, 1990. p. 5-22. (Publicação IPT, 1822).

SADLER, B.,org. Environmental assessment in a changing world: evaluating practice to improve performance. S.L., International Association for Impact Assessment/ Canadian Environmental Assessment Agency, 1996. 248p.

SADLER, B.; VERHEEN, R. Strategic environmental assessment: status, challenges and future directions. The Hague, Ministry of Housing, Spatial Planning and the Environment, 1996.

SÁNCHEZ, L. E. Considerações preliminares sobre a aplicação da avaliação de impacto ambiental na atividade de mineração no Estado de São Paulo. In: CONGRESSO ÍTALO BRASILEIRO DE ENGENHARIA DE MINAS, Cagliari, 1990. Anais. Cagliari, Universita degli Studi di Cagliari, 1990. p. 463-38.

SÁNCHEZ, L.E. O processo de avaliação de impacto ambiental, seus papéis e funções. In: SÃO PAULO. Secretaria do Meio Ambiente. Coordenadoria de Planejamento Ambiental. A efetividade da avaliação de impacto ambiental no Estado de São Paulo: uma análise a partir de estudos de caso. São Paulo, SMA, 1995a. p. 13-9. 
SÁNCHEZ, L.E. Control de la contaminación de las aguas. In: REPETO, F.L.; KAREZ, C. S., eds. Aspectos geológicos de protecion ambiental. Montevideo, ORCYT/UNESCO, 1995b. v. 1, p. 155-68.

SÁNCHEZ, L.E. Manejo de resíduos sólidos en mineria. In: REPETO, F.L.; KAREZ, C. S., eds. Aspectos geológicos de protecion ambiental. Montevideo, ORCYT/ UNESCO, 1995c. v.1, p. 135-44.

SÁNCHEZ, L.E. Control de la contaminación del aire. In: REPETO, F.L.; KAREZ, C. S., eds. Aspectos geológicos de protecion ambiental. Montevideo, ORCYT/ UNESCO, 1995d. v. 1, p. 197-204.

SÁNCHEZ, L.E. Ruido y sobrepression atmosférica. In: REPETO, F.L.; KAREZ, C. S., eds. Aspectos geológicos de protecion ambiental. Montevideo, ORCYT/ UNESCO, 1995e. v. 1, p. 189-96.

SÁNCHEZ, L.E. Control de las vibraciones. In: REPETO, F.L.; KAREZ, C. S., eds. Aspectos geológicos de protecion ambiental. Montevideo, ORCYT/UNESCO, 1995f. v. 1, p. 179-88.

SÁNCHEZ, L.E. Impactos sobre el medio antropico. In: REPETO, F.L.; KAREZ, C. S., eds. Aspectos geológicos de protecion ambiental. Montevideo, ORCYT/ UNESCO, 1995g. v. 1, p. 205-11.

SÁNCHEZ, L. E. As etapas iniciais do processo de avaliação de impacto ambiental. In: SÃO PAULO. Secretaria do Meio Ambiente. Avaliação de impacto ambiental. São Paulo, SMA, 1998. v. 1, p. 35-55.

SÁNCHEZ, L. E. Avaliação de impacto ambiental. São Paulo, PECE, 1999. /Notas de aula da disciplina AI002 - Avaliação de Impacto Ambiental/

SANTOS, R. C.; MAZZON, J.A. Challenges for the internationalization of environmental management in companies: an exploratory study in Brazil. In: ANNUAL CONFERENCE OF BUSINES ASSOCIATION OF LATIN AMERICAN STUDIES. Latin American in the 21st century - the next ten years: proceedings. Washington, BALAS, 1995. p. 1-15.

SÃO PAULO. Secretaria do Meio Ambiente Critérios de exigência de EIA/Rima e roteiros para sua elaboração em relação a usinas de reciclagem elou compostagem, aterros para resíduos sólidos domiciliares e industriais e incineradores: manual de orientação. São Paulo, SMA, 1991a. (Série Manuais).

SÃO PAULO. Secretaria do Meio Ambiente Manual para adequação ambiental na implantação de distritos industriais. São Paulo, SMA, 1991b. (Série Manuais).

SÃO PAULO. Secretaria do Meio Ambiente Consema: dez anos de atividades. São Paulo, SMA, 1993. (Série Documentos).

SÃO PAULO. Secretaria do Meio Ambiente Relatório ambiental preliminar-RAP: roteiros básicos. São Paulo, SMA, 1998. (Documentos Ambientais).

SÃO PAULO. Secretaria do Meio Ambiente Procedimento de licenciamento ambiental integrado para atividades minerárias no Estado de São Paulo. São Paulo, SMA, 1999. (Manuais Ambientais).

SÃO PAULO. Secretaria do Meio Ambiente. [on line] São Paulo, 2000a. Disponível através de http://www.ambiente.sp.gov.br/menu.htm. [Arquivo capturado em $14 \mathrm{de}$ março de 2000] 
SÃO PAULO. Secretaria do Meio Ambiente. [on line] São Paulo, 2000b. Disponível através de http://www.ambiente.sp.gov.br/cprn/tabdaia.htm. [Arquivo capturado em 29 de junho de 2000]

SEARA FILHO, G., org. Consema: mais cinco anos de atividades. São Paulo, SMA, 1998.

SHIMIZU, G.Y. et al. Lagoas de mineração de areia: impactos sobre os parâmetros ambientais e comunidades bióticas. In: SIMPÓSIO BRASILEIRO DE RECURSOS HÍDRICOS, 11./ SIMPÓSIO DE HIDRÁULICA E RECURSOS HÍDRICOS DOS PAÍSES DE LÍNGUA OFICIAL PORTUGUESA, 2., Recife, 1995. Anais. Recife, ABRH, 1995. v. 3, p. 269-74.

SISKIND, D. E. et al. Structure response and damage produced by ground vibration from surface mine blasting. Washington, U.S. Bureau of Mines, 1980. (U.S.B.M. Report of Investigation, 8507)

SOUZA, P. A. Impacto econômico da questão ambiental no processo decisório do investimento em mineração. Campinas, 1999. 267 p. Tese (Doutorado) - Instituto de Geociências, Universidade Estadual de Campinas.

THERIVEL, R. et al. Strategic environmental assessment. London, Earthscan, 1992. $181 \mathrm{p}$.

TOMLINSON, P. Screening and scoping methods. /Apresentado ao International Seminar on Environmental Impact Assessment, Aberdeen, 1985. Separata/

TULL, D. S.; HAWKINS, D. I. Marketing research: meaning, measurement, and method: a text with cases. New York, Macmillan, 1976.

VALVERDE, F. M. Conflitos e soluções: o caso de São Paulo. Brasil Mineral, n. 125, p. 60-6, 1994.

VAN ACKER, F. T. Os estudos de impacto ambiental: da Resolução 1/86 à Resolução 237/97 do Conama. In: SÃO PAULO. Secretaria do Meio Ambiente. Avaliação de impacto ambiental. São Paulo, SMA, 1998. v. 1, p. 25-29.

WLODARCZYIK, M. E. S. Improving monitoring and follow-up in Canadian environmental assessments. In: ANNUAL MEETING OF THE INTERNATIONAL ASSOCIATION FOR IMPACT ASSESSMENT, 20., Hong Kong, 2000. /Selected papers/ Fargo, IAIA, 2000. n.p.

WOOD, C. Environmental impact assessment: a comparative review. Essex, Longman, 1995.

WOOD, C.; COPPELL, L. An evaluation of the Hong Kong environmental impact assessment system. Impact Assessment and Project Appraisal, v. 17, n. 1, p. 21-31, Mar. 1999.

WOOD, C.; DEJEDDOUR, M. Strategic environmental assessment: EA of policies, plans and programs. Impact Assessment Bulletin, v. 10, n. 1, p. 3-22, 1992.

WORLD RESOURCES INSTITUTE/THE WORLD CONSERVATION UNION/ PROGRAMA DAS NAÇÕES UNIDAS PARA O MEIO AMBIENTE. A estratégia global da biodiversidade: diretrizes de ação para estudar, salvar e usar de maneira sustentável e justa a riqueza biótica da Terra. Curitiba, Fundação O Boticário de Proteção à Natureza, 1992. 
YIN, R. K. Case study research: design and methods. 2 ed. Thousand Oaks, Sage, 1994.

YOCOM, J. E. Stone and quarrying processing. In: BUONICORE, A. J.; DAVIS, W. T., eds. Air pollution engineering manual. New York, Van Nostrand, 1992. p. $780-7$.

YOUNG, J.E. Mining the Earth. In: BROWN, L.R. State of the world. New York, Norton, 1992. p. 100-18. 